UNIVERSIDADE DE SÃO PAULO

FACULDADE DE ECONOMIA, ADMINISTRAÇÃO E CONTABILIDADE DEPARTAMENTO DE ADMINISTRAÇÃO

PROGRAMA DE PÓS-GRADUAÇÃO EM ADMINISTRAÇÃO

\title{
A INFLUÊNCIA DOS TRAÇOS DE PERSONALIDADE NA FORMAÇÃO DOS CONTRATOS PSICOLÓGICOS
}

\author{
Leticia Fantinato Menegon
}

Orientadora: Profa. Dra. Tania Casado

SÃO PAULO 
Profa. Dra. Suely Vilela

Reitora da Universidade de São Paulo

Prof. Dr. Carlos Roberto Azzoni

Diretora da Faculdade de Economia, Administração e Contabilidade

Prof. Dr. Adalberto Américo Fischmann

Chefe do Departamento de Administração

Prof. Dr. Lindolfo Galvão de Albuquerque

Coordenador do Programa de Pós-Graduação em Administração 


\title{
LETICIA FANTINATO MENEGON
}

\section{A INFLUENCIA DAOS TRAÇOS DE PERSONALIDADE NA FORMAÇÃO DOS CONTRATOS PSICOLÓGICOS}

\author{
Tese apresentada ao Departamento de \\ Administração da Faculdade de Economia, \\ Administração e Contabilidade da \\ Universidade de São Paulo como requisito \\ para obtenção de título de Doutor em \\ Administração.
}

Orientador: Profa. Dra. Tania Casado 


\section{FICHA CATALOGRÁFICA}

Elaborada pela Seção de Processamento Técnico do SBD/FEA/USP

Menegon, Leticia Fantinato

A influência dos traços de personalidade na formação dos contratos psicológicos / Leticia Fantinato Menegon. -- São Paulo, 2009.

$166 \mathrm{p}$.

Tese (Doutorado) - Universidade de São Paulo, 2010.

Bibliografia.

1. Administração de recursos humanos 2. Psicologia organizacional 3. Contratos - Aspectos psicológicos I. Universidade de São Paulo. Faculdade de Economia, Administração e Contabilidade II. Título. 
Dedico esta tese a meus pais Maria Inês e Dimas, pelo apoio, encorajamento, ensinamentos, valores e amor que foram essenciais para a construção da minha história. Vocês são meu maior exemplo de força e superação. Ao meu marido Alexandre, pelo amor, compreensão e paciência durante essa longa trajetória.

Ao meu filho André, minha fonte de inspiração e alegria, que ensinou-me o verdadeiro significado da expressão amor incondicional. Eu prometo que a partir de agora terei muito tempo para brincar com você! A Deus, por iluminar meu caminho. 
São muitas as pessoas que gostaria de agradecer pela contribuição que deram de alguma forma a realização deste trabalho.

Agradeço especialmente à professora Tania Casado, a qual conduziu o processo de orientação de forma tranqüila e serena, atuando sempre em parceria. Suas contribuições foram muito importantes para meu crescimento acadêmico. Muito obrigada pela sua dedicação, envolvimento e paciência.

Agradeço à minha amiga Tatiana Iwai, não somente pela amizade sincera, mas pelo tempo dedicado a discutir, nas mesas de bar, em seus momentos de descanso, minha tese. Suas contribuições e questionamentos foram importantes, pois seu "olhar de fora" ajudou-me a enxergar a questão do contrato psicológico sob um prisma diferente.

Agradeço aos meus amigos com os quais pude compartilhar momentos de angústias e alegrias na consecução deste trabalho.

Agradeço à Reni Berezin, pela extremada paciência e envolvimento, e pelos ensinamentos.

Ressalto a importância do apoio desta Instituição e seus Professores para a realização deste trabalho. 


\section{RESUMO}

Este trabalho concentra-se no estudo de um dos instrumentos específicos utilizados pelas organizações para administrar suas relações com seus empregados - o contrato psicológico. Por meio de uma pesquisa descritiva, buscou-se responder se os traços de personalidade influenciam na formação dos tipos de contratos psicológicos, bem como na percepção de ruptura e violação dos mesmos. A base teórica escolhida pra o desenvolvimento desta tese é a psicologia analítica de Carl Gustav Jung. Para tanto, foi realizada uma pesquisa, utilizando-se o método quantitativo, com 528 alunos e ex-alunos de um curso de pós-graduação lato sensu. A taxa de resposta da pesquisa aplicada foi de 34,84\% da amostra inicial. Os resultados apresentaram associação entre as funções psíquicas racionais (pensamento e sentimento) e a formação da tipologia do contrato psicológico (relacional e transacional), contribuindo para o preenchimento de uma das maiores lacunas ainda presente nos estudos sobre o tema: a influência que a personalidade exerce na formação dos contratos psicológicos. 


\begin{abstract}
This work focuses on a study of the specific tools used by organizations to manage their relationships with their employees - the psychological contract. Through a descriptive study, we sought to answer whether personality traits influence the formation of psychological contracts types, as well as the perception of breach and violation of them. The theoretical basis chosen to develop this thesis is the analytical psychology of Carl Gustav Jung. Therefore, a survey was conducted, using the quantitative method, with 528 students and former students of a post-graduate course. The response rate of applied research was $34.84 \%$ of the initial sample. The results showed an association between the rational psychic functions (thinking and felling) and the formation of the type of psychological contract (relational and transactional), helping to fill one of the biggest gaps still present in the studies on the subject: the influence that personality plays in the formation of psychological contracts.
\end{abstract}




\section{Sumário}

1. Introdução .01

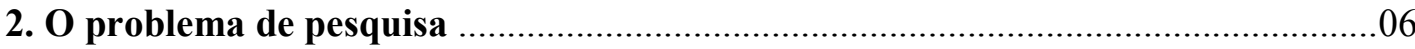

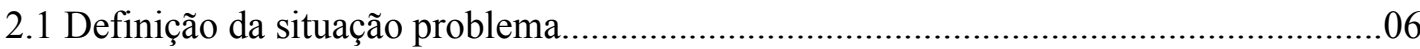

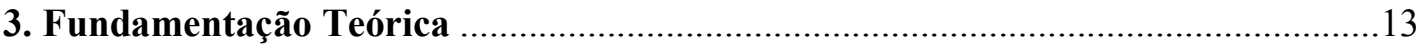

$3.1 \mathrm{O}$ desenvolvimento do conceito Contrato Psicológico..................................................13

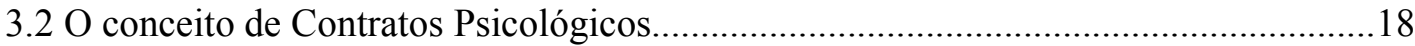

3.3 A corrente contemporânea do Contrato Psicológico......................................................22

3.4 O conteúdo e a categorização dos Contratos Psicológicos...........................................29

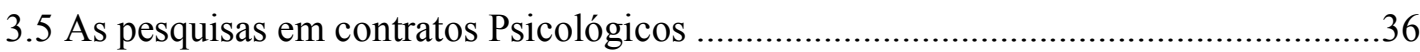

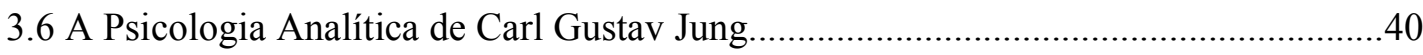

3.6.1 A estrutura da personalidade.....................................................................

3.6.2 A descrição geral dos tipos.............................................................................4

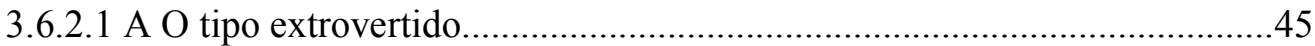

3.6.2.1.1 A atitude geral da consciência..........................................................45

3.6.2.1.2 A atitude geral da inconsciência..........................................................46

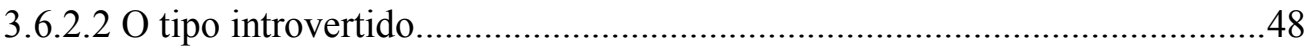

3.6.2.2.1 A atitude geral da consciência...........................................................48

3.6.2.2.2 A atitude geral da inconsciência.........................................................48

3.6.3 As funções psíquicas .................................................................................49

3.6.3.1 Funções irracionais ou perceptivas............................................................51

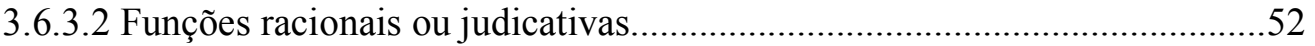

3.6.3.3 Função superior e inferior.....................................................................53

3.6.3.4 Os mecanismos compensatórios nas funções psíquicas...............................55

3.6.3.4.1 Mecanismos compensatórios das funções perceptivas sensação e intuição

3.6.3.4.2 Mecanismos compensatórios das funções judicativa pensamento e 
3.6.4 A interação entre os tipos gerais de atitude e as funções psíquicas superiores

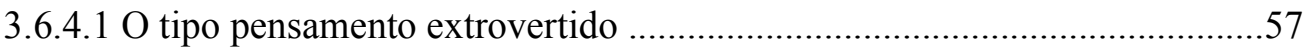

3.6.4.2 O tipo sentimento extrovertido .............................................................5

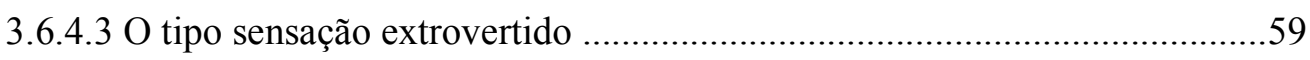

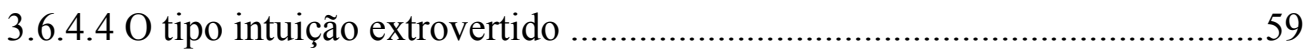

3.6.4.5 O tipo pensamento introvertido...............................................................60

3.6.4.6 O tipo sentimento introvertido....................................................................

3.6.4.7 O tipo sensação introvertido.....................................................................61

3.6.4.8 O tipo intuição introvertido .....................................................................62

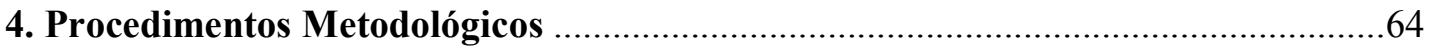

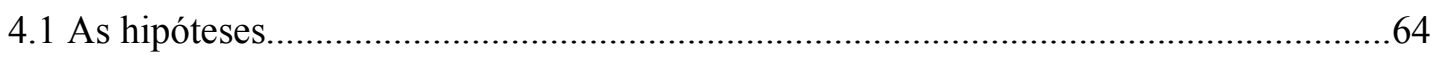

4.1.1 Os tipos gerais de atitude e os Contratos Psicológicos.................................65

4.1.2 As funções psíquicas e os Contratos Psicológicos ....................................... 66

4.1.3 A função superior e a violação dos Contratos Psicológicos .........................69

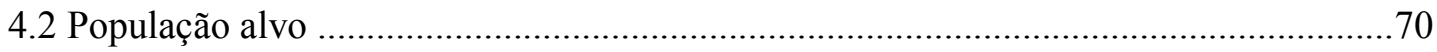

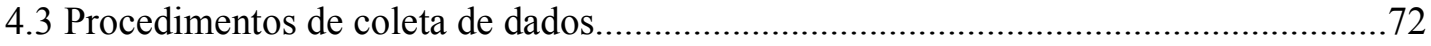

4.3.1 O instrumento de coleta de dados................................................................

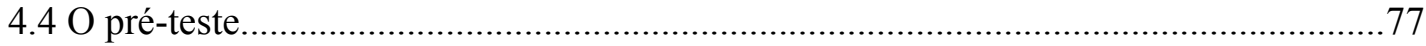

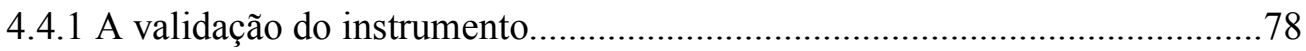

4.1.2 A segunda validação do instrumento .........................................................86

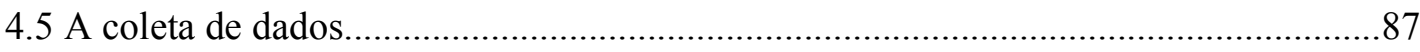

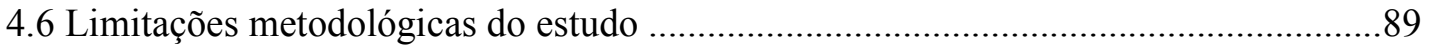

5. Apresentação, Análise e Interpretação dos Resultados ...............................................90

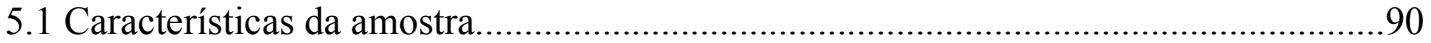

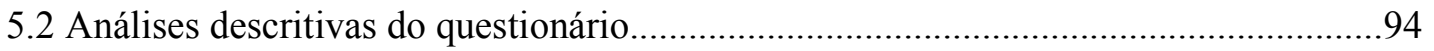

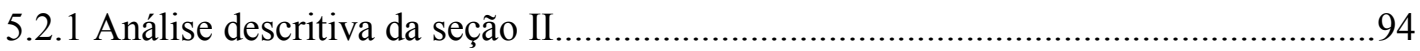

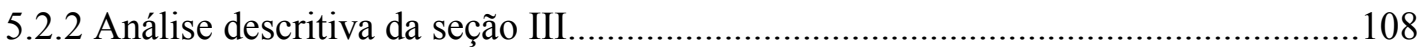

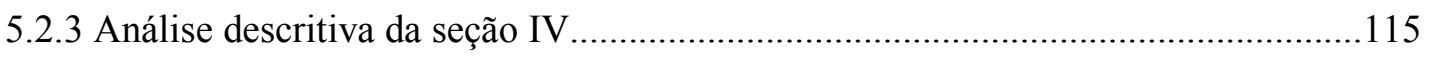


5.3 O teste das hipóteses.

119

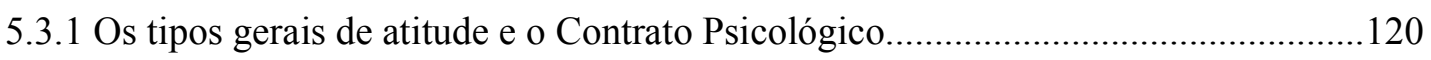

5.3.3 A função superior e a violação do Contrato Psicológico..........................................123

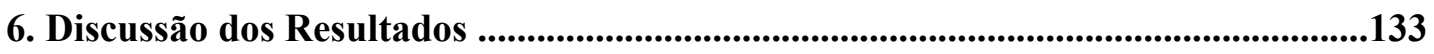

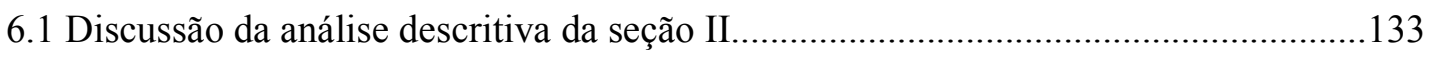

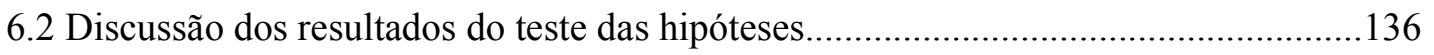

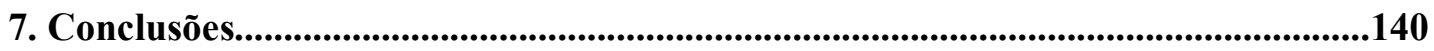

8. Recomendações aos indivíduos e organizações.........................................................145

9. Contribuições da Pesquisa.......................................................................................................146

Referencial bibliográfico...............................................................................................................147

Apêndice 1......................................................................................................................................153

Apêndice 2 ...................................................................................................................................159

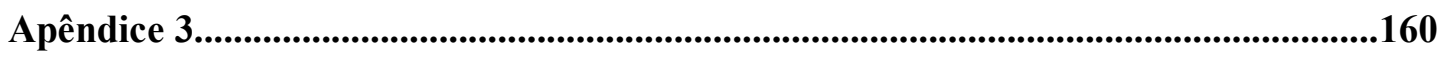

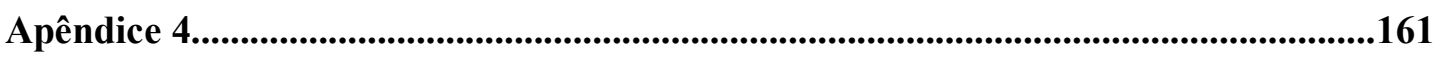

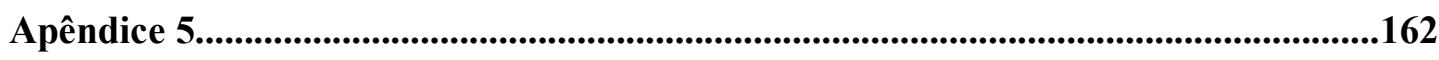

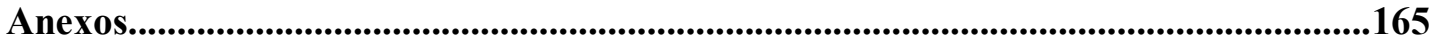




\section{Introdução}

Nas últimas décadas, a sociedade tem vivido profundas transformações em diferentes campos - social, político, econômico e tecnológico, dentre outros. Ao observar especificamente as organizações percebe-se que tais transformações impactaram sua estrutura produtiva, antes basicamente industrial e agora baseada na informação e no conhecimento; a competitividade, que se tornou acirrada; a organização do trabalho, que tem sua estrutura modificada diante das novas exigências do mercado; as relações cliente-empresa, empresamercado, caracterizadas por níveis de exigência cada vez maiores. (RIFKIN, 1996)

Diante destas mudanças, a figura do trabalhador ganha outro significado: deixa de ser mão-de-obra operacional para ser o trabalhador do conhecimento, compondo o capital intelectual da empresa - a soma de tudo o que todos sabem (expertises, idéias, criatividade, competências entre outros) em uma companhia, proporcionando competitividade (STEWART, 1999). Nesta nova era, o conhecimento e a informação são as principais matérias-primas e mais importantes produtos da economia. Não se vende mais um produto físico, mas sim o conhecimento envolto no produto. "A vantagem competitiva da organização advém do valor que esta pode desenvolver para seus clientes - valor que emana do conhecimento de seus funcionários" (LAHTI e BEYERLEIN, 2000 p. 65). Lee e Maurer (1997) complementam essa argumentação, quando expõem que o trabalhador do conhecimento se tornou chave para a empresa se manter competitiva. (LEE e MAURER, 1997, p. 248).

Esta realidade impactou profundamente as relações de trabalho entre organizações e trabalhadores, provocando conseqüências na forma como indivíduos se envolvem nas organizações em que trabalham (PEARCE, 1993). Surgiram novos padrões de contratação e atuação de trabalho mais flexíveis, como terceirizações ${ }^{1}$, quarteirizações ${ }^{2}$, contratações temporárias, teletrabalho ${ }^{3}$, empreendedorismo, trabalho informal ${ }^{4}$ ou de meio período, entre outros. (MILLWARD e HOPKINS, 1998; GUEST, 2004; FRIEDMAN, 2005). Os contratos, na velha relação de trabalho, deixam de ser apropriados, porque o empregado, na nova

\footnotetext{
${ }^{1}$ Transferência, a terceiros, de processos auxiliares (atividade-meio) à atividade principal (atividade-fïm).

${ }^{2}$ Delegação da gestão /administração das relações com os demais prestadores de serviços, sejam eles terceiros, parceiros ou fornecedores da instituição.

${ }^{3}$ Forma de trabalho realizada em lugar distante do escritório e/ou centro de produção, que permita separação física e que implique no uso de uma tecnologia facilitadora da comunicação.

${ }^{4}$ Trabalho sem vínculos ou benefícios fornecidos por uma empresa, sem carteira assinada, renda fixa e férias pagas.
} 
configuração que se estabelece, passa a ser um residente temporário na organização (HANDY, 1994). Frente a esse cenário, a nova relação de trabalho torna-se mais dinâmica. Indivíduos encontram-se cada vez mais envolvidos em trabalhos de curto prazo, desenvolvendo contratos mais individualizados com as organizações, deixando para trás a lógica dos contratos permanentes de emprego, que na maioria das vezes eram coletivos (O’REILLY, 1994; GUEST, 2004). Alguns reflexos disso para as organizações são: impacto no comportamento organizacional, nas práticas de recursos humanos e retenção de talentos e na gestão de carreira.

Os Contratos Psicológicos surgem como uma alternativa à gestão das relações tradicionais de trabalho, bem como uma resposta às novas configurações organizacionais, porque ajudam a descrever e entender as mudanças vividas na relação empregador e empregado. (ARNOLD, 1996; COYLE-SHAPIRO e KESSLER, 2000 ).

De acordo com Conway e Briner (2005), o conceito de Contratos Psicológicos pode ser utilizado para explicar o comportamento de indivíduos nas organizações uma vez que trata da percepção de troca recíproca na relação empregado-empregador. Para estes autores, o foco da teoria sobre Contratos Psicológicos está no relacionamento de trabalho, algo negligenciado em outras abordagens teóricas que envolvem comportamento organizacional. "Although the relevance of social relationship at work is acknowledged they do not place the relationship between employer and employee centre-stage as is the case of psychological contract." (CONWAY e BRINER, 2005, p. 2). Argumentam, em paralelo, que pelo fato do conceito se referir à percepção de uma troca recíproca na relação, o comportamento do empregado no trabalho pode ser melhor entendido como um processo dinâmico e contínuo, em que empregados têm postura ativa. Atualmente, as abordagens tratam esse comportamento como uma simples relação de causa e efeito, colocando o empregado em um papel relativamente passivo, simplesmente reagindo aos vários estímulos da organização.

Rousseau (1989), principal referência nas discussões sobre Contratos Psicológicos, aponta a importância dos estudos sobre os Contratos Psicológicos na discussão sobre estratégia organizacional e as práticas de recursos humanos. Segundo a autora, para que as organizações consigam implementar suas estratégias em um ambiente competitivo e de profundas mudanças, estas precisam delinear práticas condizentes com seus objetivos estratégicos e possuir capital humano compatível e adequado.

\footnotetext{
${ }^{5}$ Ainda que se conheça a relevância dos relacionamentos no ambiente de trabalho, as discussões sobre esse tema não colocam o relacionamento entre empregador e empregado no centro das atenções como fazem os estudos sobre Contratos Psicológicos.
} 
As práticas de recursos humanos contribuem para a modelagem do comportamento diário dos membros da organização. Conforme explica Rousseau (1989), estas são os principais meios pelos quais trabalhadores e organização contratam, pois enviam mensagens contundentes entre os participantes do contrato. As práticas de $\mathrm{RH}$ indicam quais estratégias estão sendo implementadas e como os contratos estão sendo criados para suportá-las. Estratégias e práticas de RH desalinhadas, provavelmente, geram contratos pouco condizentes com a realidade. Neste caso, os contratantes podem sentir-se lesados, produzindo comportamentos, emoções e atitudes inadequadas no ambiente organizacional, provocando, por exemplo, insatisfação, perda de lealdade, rotatividade voluntária por parte do empregado. (MENEGON, 2004, MENEGON e CASADO, 2005, TURNLEY e FELDMAN, 1999).

Os conceitos de carreiras e de Contratos Psicológicos produzem um diálogo interessante. As mudanças sociais e econômicas expostas anteriormente impactaram a gestão de carreiras. No paradigma industrial estas apareciam basicamente sob a forma de carreiras organizacionais. Com o desenvolvimento de uma economia mais dinâmica e as mudanças sociais, o conceito de carreira desenvolve-se, surgindo um debate sobre as novas formas de carreira. (ARTHUR e ROUSSEAU, 1996). Dentre eles está o conceito de carreiras sem fronteiras, que propõe:

novas formas de atuação e interação em um modelo onde os indivíduos transitam mais livremente entre as diversas organizações adquirem competências que os permitem atuar em diversos contextos diferentes, participam de redes de relacionamento abrangente, desatrelam suas identidades de um empregador específico e permitem a incorporação de outras dimensões da vida humana, além da profissional, como elementos vitais a sua realização profissional - construindo, dessa forma, uma definição de sucesso que lhes é particular e subjetiva. (SCALABRIN, 2008, p.14).

Dentro dessas novas formas de atuação e interação expostas pela autora, em que há um trânsito mais livre de indivíduos em diversas organizações, o diálogo que se impõe é que os Contratos Psicológicos acabam por suportar o caráter dinâmico deste novo tipo de carreira, pois conforme mencionado por Conway e Briner (2005), tais contratos referem-se a processos mais dinâmicos e contínuos, em que o empregado posiciona-se mais ativamente. Ao desenvolver a carreira sem fronteiras, o indivíduo estabelecerá diferentes Contratos Psicológicos com diferentes atores sociais, que podem ou não fazer parte da organização para a qual trabalha, mas que participam da construção de sua carreira. Para tanto, diálogos e negociações tornar-se-ão fundamentais nesse processo. E as organizações deverão atentar para 
a criação de práticas de recursos humanos que possibilitem a conversa entre estes dois conceitos, promovendo sinergia entre os diferentes temas discutidos até o momento, contribuindo para a retenção de talentos organizacionais.

A massa crítica de pesquisas e discussões sobre Contratos Psicológicos vem sendo desenvolvida, principalmente, nos Estados Unidos da América. Raras pesquisas desenvolveram-se no Brasil, e em outras partes do mundo, o que pode limitar o desenvolvimento teórico e prático do tema. Com o intuito de contribuir para a construção do conhecimento sobre os Contratos Psicológicos, foi conduzida uma pesquisa inédita com executivos de diversas empresas, que teve por objetivo verificar como as diferenças individuais (personalidade) contribuem para a formação dos Contratos Psicológicos.

O presente trabalho está divido em nove capítulos.

O primeiro é o capítulo introdutório, que desenvolve um panorama geral a respeito dos temas que envolvem a tese.

O segundo capítulo trata da definição do problema de pesquisa, descrevendo a argumentação para fundamentar a escolha dos objetivos da tese. Apresenta as abordagens teóricas escolhidas para o seu desenvolvimento.

O terceiro capítulo apresenta a fundamentação teórica sobre os temas mais relevantes para o entendimento dos objetivos centrais da tese, bem como o delineamento de suas hipóteses. Está dividido em dois grandes blocos de conhecimento: Contratos Psicológicos e a Psicologia Analítica de Carl Gustav Jung.

O quarto capítulo é composto dos procedimentos metodológicos adotados. É composto pelo delineamento das hipóteses e suas justificativas, a população-alvo definida para a realização da pesquisa, os procedimentos de coleta de dados, os testes pilotos realizados para a validação do instrumento de coleta de dados e a descrição da coleta de dados.

O quinto capítulo apresenta, analisa e interpreta os dados coletados. Para tanto, está estruturado em cinco grandes blocos, a saber: 1) as características descritivas da amostra estudada; 2) as respostas descritivas obtidas nas seções II, III e IV do questionário; 3) o teste das hipóteses; 4) as discussões dos resultados e 5) as limitações do estudo.

O capítulo seis discute os resultados obtidos à luz de diferentes teorias. Para tanto, discutem-se os resultados descritivos da seção II do questionário, os resultados relativos às hipóteses de nulidade delineadas para esta tese, que representam as seções III e IV do 
questionário. Os resultados passíveis de discussão são apresentados previamente às reflexões pertinentes e sugestões de estudos posteriores relativos às mesmas são propostas.

O capítulo sete retoma os objetivos e hipóteses estabelecidas para a tese e apresenta as conclusões relativas a cada um dos resultados obtidos.

O capítulo oito apresenta algumas recomendações aos indivíduos e organizações, enquanto o capítulo nove discorre sobre as contribuições da pesquisa para as ciências humanas, indivíduos, organizações e gestores de pessoas. 


\section{O problema de pesquisa}

\subsection{Definição da situação problema}

As relações de trabalho passaram por profundas mudanças como conseqüência dos processos de globalização, reestruturação organizacional e produtiva, e downsizing (CoyleShapiro e Kessler, 2000). Regidas por uma forte interação entre empresas, sindicatos e governo, as relações de trabalho, no passado, desenvolviam-se sob forte militância dos atores envolvidos no que se refere ao processo de negociação das condições de trabalho oferecidas pelas empresas a seus trabalhadores.

$\mathrm{Na}$ medida em que novas configurações sócio-politco-econômico-legais ganham espaço na sociedade e, por conseqüência, nas organizações, as relações de trabalho tradicionais foram rapidamente impactadas e, nas últimas décadas, observou-se uma tendência quase mundial (salvaguardando as particularidades de cada país) de enfraquecimento das mesmas. (COSTA, 2008).

Historicamente, a estrutura sindical esteve associada às massas trabalhadoras, especialmente do setor industrial. As mudanças ocorridas neste setor, como diminuição na oferta de vagas de empregos, frente ao aumento da participação do setor de serviços na economia mundial dificultou o acesso dos sindicatos a uma classe de trabalhadores com fraca cultura de sindicalização. Ademais, as políticas neoliberais observadas na maioria dos países ocidentais propiciaram desregulamentações no campo trabalhista, contribuindo para a diminuição da filiação sindical. (COSTA, 2008).

Guest (2004) elencou alguns fatores que afetaram e ainda afetam a viabilidade da relação tradicional de trabalho e seus modelos analíticos.

O primeiro fator citado pelo autor é o declínio do número de trabalhadores empregados em empresas, o que dificulta a organização da força de trabalho pelo sindicato. Tal configuração aumenta a responsabilidade dos trabalhadores no espaço organizacional, propiciando uma relação mais próxima entre gestores e trabalhadores, limitando a necessidade por representação sindical. Em empresas menores é mais "fácil que o informal predomine sobre o formal, afastando a ênfase sobre os acordos coletivos existentes no sistema tradicional formal" (GUEST, 2004, p. 543). No Brasil, os sindicatos encontram-se muito pulverizados, 
devido à especialização das categorias sindicais. Isto enfraquece sua atuação sobre grandes acordos coletivos (RODRIGUES, 2002).

O segundo fator tratado por Guest (2004) é o aumento da flexibilidade e fragmentação da força de trabalho. Novos padrões emergiram: flexibilização das horas de trabalho, aumento da terceirização, diferentes variedades de contratos de trabalho, equipes virtuais e assim por diante. Tais padrões remetem a uma diminuição do senso de identidade entre as pessoas, dificultando um posicionamento coletivo no processo de negociação entre trabalhador e empregador. Esta nova situação impõe desafios à gestão das relações de trabalho, nas quais não imperam mais as grandes negociações sindicais. No Brasil, a flexibilidade e fragmentação da força de trabalho ocorrem, mas de forma mais tímida que em outros países, uma vez que nossa legislação trabalhista é bastante rígida. A flexibilização da força de trabalho pode ocorrer, desde que por meio de acordo coletivo, enquanto a terceirização deve ocorrer apenas para as atividades meio das organizações, com o objetivo de evitar a precarização do trabalho. (PASTORE, 2008). De qualquer forma, esse padrão adotado por muitas empresas brasileiras impacta, certamente, as relações de trabalho.

O terceiro fator refere-se aos avanços tecnológicos, responsáveis em grande parte pelo aumento da velocidade no ambiente de trabalho, condição importante no cenário competitivo glocal. A urgência por dinamismo confronta-se diretamente com a lentidão dos processos de negociação coletiva. Além do mais, frente às rápidas mudanças nos contextos sócio-políticoeconômico-legais, aquilo que é negociado hoje pode não ser mais considerado em um futuro próximo.

O quarto fator é o aumento do interesse dos trabalhadores por um balanceamento entre vida pessoal e profissional (MAINIERO e SULLIVAN, 2006, SCALABRIN, 2008), que se torna importante dentro de um contexto em que as organizações buscam atrair e reter talentos.

While a negotiated floor of rights and opportunities may be determined through collective bargaining, supported by the legislative framework, there are likely to be many local "deals" reflecting personal circumstances and related understanding of what might be permitted. ${ }^{6}$ (GUEST, 2004, p.543).

\footnotetext{
${ }^{6}$ Enquanto uma negociação de direitos e oportunidades pode ser determinada por meio de negociação coletiva, apoiada pela legislação, provavelmente ocorram muitas negociações locais que reflitam as circunstâncias pessoais e entendimentos do que pode ser permitido.
} 
Harrington e Hall (2007) apontam uma mudança na relação estabelecida entre trabalhadores e empregadores: "The employer-employee contract has been dramatically altered as leading organizations have moved from practices of lifelong (...) employment to a more free-agent approach to managing their workforce."7 (HARRINGTON e HALL, 2007, p. ix). Ocorre uma mudança no conceito de carreira, já que a responsabilidade do gerenciamento da carreira é transferida das mãos da organização para as do trabalhador. Com isso, a contratação no ambiente de trabalho deixa de ser massificada para ser individualizada, refletindo a combinação das diferentes necessidades de empresas e trabalhadores.

Paralelamente às relações de trabalho, as organizações sofreram mudanças complexas no que se refere à sua própria estrutura.

The development of more complex organizational forms - such as cross organization networking, partnerships, alliances, use of external agencies for core as well as peripheral activities, multi-employer sites and the blurring of public/private sector divide - has implications for both the legal and the socially constituted nature of the employment relationship ${ }^{8}$ (RUBERY et all., 2002, p. 645)

O tema Contrato Psicológico surge como um modelo alternativo às relações tradicionais de trabalho, bem como uma resposta às novas configurações organizacionais, porque ajuda a descrever e entender as mudanças vividas na relação empregador e empregado (Arnold, 1996; Coyle-Shapiro e Kessler, 2000 ). Tal importância é expressa por DelCampo (2007):

Research in the area of psychological contract is possibly the most emergent area for organizational research (...) Recently, in a discussion about Academy of Management Organizational Behavior Division submissions, Angelo DeNisi (communication, March 2002) stated that psychological contract garnered by far the most attention from submitters to the program. Going further, he stated that papers dealing with psychological contracts were 1.5

\footnotetext{
${ }^{7} \mathrm{O}$ contrato entre empregadores e empregados foi dramaticamente alterado na medida em que organizações influentes mudaram de práticas de empregos vitalícios (...) para uma abordagem mais dinâmica e flexível no gerenciamento da sua força de trabalho.

${ }^{8} \mathrm{O}$ desenvolvimento de formas organizacionais mais complexas - como organizações em rede, parcerias, alianças, uso de agências externas no desenvolvimento de atividades centrais e periféricas, multi-empregadores e divisão pouco clara entre o setor público e privado - traz implicações legais e sociais constituintes da natureza da relação de trabalho.
} 
times as numerous as the next most popular area. ${ }^{9}$ (DELCAMPO, 2007, p. 43)

Para Shore e Tetrick (1994), o Contrato Psicológico promove a redução da insegurança na relação de trabalho porque nem todos os aspectos da mesma são abrangidos pelos contratos formais. Estes também oferecem um parâmetro para o empregado sobre o que acontece com ele na organização, insumo importante para decisões sobre carreira. E, por último, este mesmo contrato modela o comportamento do empregado, pois este entende, sob uma perspectiva crítica, o que a organização espera dele.

De acordo com Conway e Briner (2005), há três importantes aspectos sobre o conceito de Contrato Psicológico que não são abordados em outros temas que tratam do comportamento humano no trabalho. O primeiro deles é que na discussão dos Contratos Psicológicos há um foco claro no relacionamento empregador-empregado, negligenciado em outras abordagens

Although the relevance of social relationship at work is acknowledged they do not place the relationship between employer and employee centre-stage as is the case with the psychological contract. ${ }^{10}$ (CONWAY e BRINER, 2005, p. 2).

O segundo é que a relação empregatícia é vista sob o ângulo da troca. As outras correntes teóricas, apesar de tratarem deste aspecto, não o exploram em detalhes. $\mathrm{O}$ terceiro, expressa-se bem nas palavras dos autores:

(...) because the psychological contract is about perceptions of reciprocal exchange relationship, it implies that employee behavior is best understood as a dynamic and ongoing process and one in which employees are active. Other explanations of behavior at work often seem to look at behavior in terms of simple cause and effect, rather than processes, and place the employee in a

\footnotetext{
${ }^{9}$ Pesquisa na área de Contratos Psicológicos é possivelmente a área mais emergente de pesquisas em organizações (...) Recentemente, em uma discussão sobre as submissões da Divisão do Academy of Management Organizational Behavior, Ângelo DeNise (Comunicação, Março 2002) colocou que os Contratos Psicológicos reuniram de longe a maior atenção dos aplicadores do programa. Indo além, ele disse que os trabalhos sobre Contratos Psicológicos eram 1,5 vez mais numerosos do que a outra área de conhecimento mais popular.

${ }^{10}$ Apesar da relevância da relação social no trabalho ser reconhecida, as teorias que tratam do assunto não colocam a relação entre empregador e empregado no centro do palco como faz a teoria de Contratos Psicológicos.
} 
relatively passive role, simply reacting to various features of the context. ${ }^{11}$ (CONWAY e BRINER, 2005, p. 2).

Em vista da importância do tema Contratos Psicológicos, sua construção e discussão, apesar de antigas (Argyris, 1960; Levinson, 1962) e ignoradas pela literatura sobre comportamento humano no trabalho e relações de trabalho, ganharam força na década de 80 com o trabalho de Rousseau (1989). A partir deste, muitos pesquisadores, estudantes e mesmos gestores organizacionais interessaram-se pelo assunto. Grande parte dos trabalhos acadêmicos desenvolvidos pelos pesquisadores focou dois pontos principais sobre o tema, que são: o levantamento do conteúdo dos Contratos Psicológicos e sua categorização, e os efeitos do mesmo sobre o comportamento dos indivíduos no trabalho, principalmente no que se refere à ruptura do Contrato Psicológico (Robinson, 1996; Robinson e Rousseau, 1994; Robinson, 1995; Turnley e Feldman, 1999; Conway e Briner, 2002a; Conway e Briner, 2002 b; Lester et al. 2002; Robinson, Kraatz e Rousseau, 1994; Coyle-Shapiro e Kessler, 2002; Robinson e Morinson, 1995; Turnley e Feldman, 2000; Menegon, 2004).

Entretanto, de acordo com as leituras realizadas sobre o tema, entre eles DelCampo (2007); Raja, Johns e Ntalianis (2004); Meckler, Drake e Levinson (2003) e Conway e Briner (2005), poucos estudos têm examinado os antecedentes da formação e ruptura dos Contratos Psicológicos sob o prisma das experiências profissionais anteriores do indivíduo, das suas experiências fora da organização e de sua personalidade. Conway e Briner (2005), em um amplo estudo da produção acadêmica mundial, apresentam dezenas de apontamentos ainda não respondidos pelas pesquisas, dentre os quais "Little is known about how individual differences (such as personality) (...) affect the contents of psychological contracts."12 (CONWAY e BRINER, 2005, p. 112). Isto posto, observa-se claramente que os estudos sobre Contratos Psicológicos não abordaram questões como "De onde surgem as diferenças de interpretação de um Contrato Psicológico?”; “As diferenças individuais contribuem para diferentes percepções na relação empregador-empregado, de modo a impactar a formação de diferentes Contratos Psicológicos?”.

\footnotetext{
${ }^{11}(\ldots)$ porque o Contrato Psicológico trata da percepção de troca recíproca na relação, isso implica que o comportamento do empregado é melhor compreendido como um processo dinâmico em que os empregados são ativos. Outras explicações sobre o comportamento no trabalho freqüentemente enxergam o comportamento em termos de causa e efeito, em vez de processo, colocando o empregado em um posição passiva, simplesmente reagindo às várias características do contexto.

${ }^{12}$ Pouco se conhece sobre como as diferenças individuas (tais como personalidade) (...) afetam o conteúdo do Contrato Psicológico.
} 
Frente ao exposto e com o intuito de contribuir para o preenchimento das lacunas apontadas por DelCampo (2007); Raja, Johns e Ntalianis (2004); Meckler, Drake e Levinson (2003) e Conway e Briner (2005), e pelas questões colocadas no parágrafo anterior, este trabalho tem por objetivos: 1) examinar se os tipos psicológicos exercem influência na captura e entendimento dos Contratos Psicológicos; 2) examinar se existe associação entre tipo psicológico e tipo de Contrato Psicológico; 3) examinar se existe associação entre o tipo psicológico e o comportamento do indivíduo quando este se depara com o não cumprimento do Contrato Psicológico.

A base teórica escolhida para o desenvolvimento deste trabalho é a Psicologia Analítica de Carl Gustav Jung. A escolha desta abordagem se deve aos aspectos essenciais e princípios norteadores da teoria junguiana, e à forte presença desta nas universidades, centros de carreira e organizações.

Um dos pontos fundamentais da obra de Jung foi a consideração dos fenômenos conscientes e inconscientes no entendimento da totalidade do ser humano. Em seus postulados, considerou que

assim como os conteúdos conscientes podem mergulhar no inconsciente, há conteúdos novos, que jamais foram conscientes, que podem surgir do inconsciente. (...) o inconsciente não é mero depositário de experiências passadas, desejos ou instintos reprimidos. (...) [e sim] uma parte tão vital e tão real da vida de uma pessoa quanto a consciência (...) (REIS, MAGALHAES e GONCALVES, 1984, p. 132).

Este confronto e relacionamento entre consciente e inconsciente permite o desenvolvimento e amadurecimento do homem e, por conseqüência, do Ego, que se modifica ao longo da vida; jamais é um produto acabado. (JUNG, 1991; CASADO, 1998).

Isto posto, "A abordagem de Jung é muito oportuna e útil aos profissionais de Administração, pois considera os estágios da vida adulta como participações importantes no processo de desenvolvimento dos indivíduos. As organizações são compostas e geridas por pessoas que já passaram da idade em que grande parte dos teóricos situa o período de desenvolvimento das pessoas: os primeiros anos de vida. (...) Tratando-se de processos vividos na idade adulta, nada mais apropriado do que utilizar uma teoria que reconheça a importância dos estágios da idade madura no desenvolvimento humano (...)." (CASADO, 1998, p. 4). 
Ademais, observa-se a presença dos postulados Junguianos em aplicações que vão além dos consultórios de psicologia. Pesquisadores de Universidades e Centros de Carreira, entre outros, desenvolveram instrumentos com o objetivo de identificar os aspectos observados por Jung nos indivíduos. Dentre eles, estão Keirsey e Bates (1978), que desenvolveram o The Keirsey Temperament Sorter; Myers e Briggs (1980), que desenvolveram, na década de 40, o MBTI - Myers Briggs Type Indicator; Wheelwright, Wheelwright e Buehler (1964), que desenvolveram o Jungian Type Survey; e, no Brasil, Casado (1998), que desenvolveu a ferramenta DTP (Diagnóstico de Tipos Psicológicos) e Zacharias (2003), que desenvolveu o QUATI (Questionário de Avaliação Tipológica).

Tais instrumentos têm ajudado não somente na orientação de alunos e profissionais, mas fornecido elementos para o entendimento das diferenças individuais e suas implicações em outros campos da ciência, contribuindo para o avanço das pesquisas.

Nas organizações, a tipologia junguiana contribui para o entendimento das diferenças individuais, fornecendo insumos para processos seletivos, resolução de problemas em grupo, desenvolvimento das capacidades dos profissionais, tomada de decisões sobre carreiras, melhoria das relações humanas e da comunicação entre pessoas, e composição de times (Myers e Myers, 1997), entre outros.

Além disso, a teoria desenvolvida por Jung tem sido amplamente publicada em revistas destinadas ao público executivo (REVISTA EXAME, 2008; BUSINESS WEEK, 2008; VOCÊ SA, 2008), demonstrando sua importância na prática organizacional. 


\section{Fundamentação Teórica}

\subsection{O desenvolvimento do conceito Contrato Psicológico}

O desenvolvimento do conceito Contrato Psicológico pode ser visto, historicamente, em duas fases. A primeira data de 1958 a 1989, período em que sua construção foi lenta e gradual, e estavam no centro da discussão sobre o tema Argyris (1960), Levinson (1963) e Schein (1965; 1980). A segunda é liderada pelo trabalho de Rousseau (1989), em que há uma nova conceituação de Contratos Psicológicos, a partir da qual, trabalhos mais robustos e extensos sobre o tema são desenvolvidos.

De acordo com Roehling (1997), a idéia introdutória de Contratos Psicológicos e sua definição de que os mesmos envolvem trocas interpessoais de coisas intangíveis é geralmente creditada a Menninger (Roehling,1997, p. 206) em seu livro Theory of Psychoanalytic Technique, o qual trata da existência de relações contratuais estabelecidas entre paciente e psicoterapeuta. Para o autor do livro, o contrato e o comportamento das partes é fortemente influenciado por processos conscientes e inconscientes e, se as partes sentirem-se satisfeitas com a troca estabelecida, este continuará em vigor.

Em 1960, Argyris publica o livro Understanding Organizational Behavior e, pela primeira vez, utiliza a terminologia Contrato Psicológico no ambiente de trabalho. Para ele, este conceito significava um acordo implícito entre empregados e empregadores:

Since the foremen realize the employees in this system will tend to produce optimally under passive leadership, and since the employees agree, a relationship may be hypothesized to evolve between the employees and the foreman which might be called the 'psychological work contract'. The employee will maintain high production, low grievances, etc., if the foreman guarantee and respect the norms of the employee informal culture (...) This is precisely what the employees need. ${ }^{13}$ (ARGYRIS, 1960, p. 97).

\footnotetext{
${ }^{13} \mathrm{Na}$ medida em que os gestores percebem que os empregados, neste sistema, tenderão a produzir de forma ótima sob liderança passiva, e desde que os empregados concordem, é possível que a relação entre gestores e empregados possa ser chamada de Contrato Psicológico. $\mathrm{O}$ empregado manterá alta produção, baixo ressentimento etc., se o gestor garantir e respeitar as normas da cultura informal dos empregados. (...) Isto é precisamente o que os empregados precisam.
} 
Argyris concluiu, a partir de uma pesquisa de campo, que a liderança organizacional era passiva e fortemente influenciada pela cultura informal dos empregados da firma. Como resultado, concluiu que os empregadores deveriam aceitar e respeitar os valores e normas dos empregados, não as desafiando ou questionado, de modo a obter uma boa performance dos mesmos. $\mathrm{O}$ autor parecia sugerir que a cultura informal dos empregados era a força geradora da formação dos Contratos Psicológicos.

Argyris, neste trabalho, demonstrou a importância do tema, mas, em nenhuma passagem de sua obra, foi realizada uma análise detalhada ou, ainda, uma investigação empírica sobre o mesmo.

Em 1963, Levinson et al. publicaram um estudo que examinava como os Contratos Psicológicos poderiam ser utilizados para promover a saúde mental dos trabalhadores. O estudo foi realizado por meio de entrevistas com 874 empregados da US utility plant. Foi a partir deste trabalho que se produziu uma tese completa, que provê um rico arcabouço teórico sobre o tema, bem como insights ainda não explorados pela comunidade acadêmica (CONWAY e BRINER, 2005, p.10).

Segundo Roehling (1997), “They observed [Levinson et.al.] that when people spoke about their work, they spoke about expectations, and that these expectations seemed to have an obligatory quality (...)"'14. (ROEHLING, 1997, p. 207).

De acordo com Levinson et al. (1962):

The expectations of both employees and company were then conceived as components of a psychological contract. Such a contract is rarely made formal. It is a much broader conception than the traditional use of the word in industrial relations where it has come to mean the specifics of a written legal agreement between management and labor. The psychological contract is a series of mutual expectations of which the parties to the relationship may not themselves be even dimly aware but which nonetheless govern their relationship to each other. ${ }^{15}$ (LEVINSON et al., 1962, p.21).

\footnotetext{
${ }^{14}$ Eles observaram [Levinson et al] que quando as pessoas falavam sobre seu trabalho, elas falavam sobre expectativas e estas expectativas pareciam ter um caráter obrigatório (...).

15 As expectativas dos empregados e da companhia eram concebidas como componentes do Contrato Psicológico. Tal contrato é raramente formal. É uma concepção mais ampla do que o uso tradicional da palavra na relação empresarial, onde significou acordos legais escritos entre gestores e empregados. O Contrato Psicológico é uma série de expectativas mútuas das quais as partes da relação podem não estar cientes, mas que, no entanto, regem as relações de uns com os outros.
} 
Em suma, é uma relação baseada em expectativas mútuas de que seus participantes podem ou não estar conscientes, mas tais expectativas regem a relação entre as partes. De acordo com os autores supracitados, a idéia central em torno do conceito é que as expectativas são geralmente implícitas, não verbalizadas, e "freqüentemente antecedem o relacionamento entre pessoa e companhia" (LEVINSON et al., 1962, p.22, tradução nossa). Neste sentido, o motivo inconsciente que leva pessoas a formarem Contratos Psicológicos vai ao encontro da definição de Menniger (1963 apud MORRINSON, 1994; CONWAY e BRINER, 2005), que trata do aspecto inconsciência como parte da definição do conceito de Contrato Psicológico. Tal inconsciência revela aspectos da personalidade do indivíduo na formação do Contrato Psicológico. Segundo Levinson et al. (1962):

Attitudes toward work help to indicate how the person is attempting to resolve psychological problems which confront everyone in becoming and remaining an adult. When a man says why he goes to work, clinical experience tells us we must listen not only to what he says. We must try also to understand what it is he cannot tell us, both because he is unaware of his unconscious motivations and because he may not feel free to tell us (...) all about his conscious reasons. From what he says as well as what he leaves unsaid, we can infer motives and expectations of those existence and intensity he himself is not fully aware. ${ }^{16}$ (LEVINSON et al., 1962, p.23-24).

A formação do Contrato Psicológico, de acordo com os mesmos autores, além de revelar aspectos da personalidade do indivíduo, também é composta de uma busca interior do indivíduo para encontrar seu lugar na vida e estabelecer sua identidade. Como conseqüência, é esperada da empresa uma substituição da autoridade paterna e a nutrição do indivíduo para que este cresça e se desenvolva (LEVINSON et.al., 1962, p.25).

Levinson et al. (1962) entendem que indivíduos possuem necessidades que os levam a estabelecer relações como forma de atendê-las. As expectativas que emergem das relações é que compõem o Contrato Psicológico. Dentro deste contexto, é possível fazer uma crítica. De acordo com esta perspectiva:

\footnotetext{
${ }^{16}$ Atitudes em relação ao trabalho ajudam a indicar como a pessoa está tentando resolver problemas psicológicos que confrontam a todos no processo do desenvolvimento da maturidade. A experiência clinica diz que quando alguém diz por que trabalha, devemos escutar não somente o que a pessoa está dizendo. Devemos tentar entender o que ela não diz, porque pode não estar ciente de suas motivações inconscientes ou porque não se sente à vontade para falar sobre suas razões conscientes. Daquilo que diz e o que não diz, podemos inferir motivos e expectativas existenciais de que ela mesma não tem consciência.
} 
(...)if the organization meets employees' needs, the employee feels obliged to reciprocate by trying to fulfill the organization's needs. Hence, needs are very closely related to the obligations that constitute the psychological contract, as Levinson et al. (1962) note: 'It is as if both employees and company are saying to one another, "You must, for I require it". ${ }^{17}$ (CONWAY e BRINER, 2005, p. 11).

Ou seja, a relação empregador-empregado é vista como uma constante satisfação das necessidades de cada uma das partes por meio de um suposto contrato. A palavra de ordem é reciprocidade. Ora, mas para que a mesma ocorra, é preciso haver consciência das partes sobre cada uma de suas necessidades. Daí, a própria definição de Levinson et al. (1962) sobre as expectativas mútuas de que as partes sequer têm consciência se enfraquece.

O trabalho seguinte sobre Contratos Psicológicos aparece em 1965, quando Schein em seu livro Organizational Psychology define Contrato Psicológico:

psychological contracts implies that the individual has a variety of expectations of the organization and that the organization a variety of expectations of him ... Expectations such as these are not written into any formal agreement between employee and organization, yet they operate powerfully as determinant of behavior. ${ }^{18}$ (SCHEIN, 1965 apud CONWAY e BRINER, p. 12, 2005).

A leitura que Conway e Briner (2005) fazem da definição anterior é a de que a forma pela qual os funcionários avaliam seus Contratos Psicológicos ocorre por meio da força de correspondência entre as suas expectativas e as organizacionais, e tais expectativas surgem das suas necessidades básicas.

Por não oferecerem uma definição distinta do conceito de expectativas (Vroom, 1964), a definição de Contrato Psicológico não gerou interesse de pesquisa pela comunidade acadêmica até 1989, quando Denise Rousseau publicou o trabalho "Psychological and Implied Contracts in Organizations", tratando os Contratos Psicológicos sob um prisma diferente do visto até então. Para ela, a definição do conceito é: “(...) an individual's beliefs regarding the terms and conditions of a reciprocal exchange between that focal person and

\footnotetext{
${ }^{17}$ Se a organização atende as necessidades do empregado, este sente a obrigação da recíproca tentando preencher as necessidades da organização. Por isso, as necessidades estão próximas das obrigações que constituem o Contrato Psicológico, como nota Levinson et al (1962): 'É como se organização e empregados dissessem: "Você deve, pois exige que".

${ }^{18}$ Contratos Psicológicos implicam que os indivíduos possuem uma variedade de expectativas em relação à organização e vice-versa... Expectativas como estas não são escritas em um acordo formal entre empregadores e empregados, ainda que operem poderosamente como determinantes do comportamento.
} 
another party. "19 (ROUSSEAU, 1989, p. 123). O foco principal nesta conceituação está na natureza promissória do Contrato Psicológico. Diferentemente de Levinson et.al. (1962), Schein (1965) e Argyris (1960) que qualificam o Contrato Psicológico como expectativa, Rousseau (1989) entende o mesmo como o produto de uma promessa, como expressa: “Key issues here include the belief that a promisse has been made and a consideration offered in exchange for it, binding the parties to some set of reciprocal obligations. "20 (ROUSSEAU, 1989, p. 123).

A diferenciação do trabalho de Rousseau em relação aos demais não está somente na natureza promissória do contrato. Também refere-se ao objeto participante do contrato e seu impulsionador.

Enquanto para a perspectiva anterior o contrato dependia do envolvimento entre duas partes, para ela o Contrato Psicológico existe "in the eye of the beholder" ${ }^{21} \mathrm{e}$ "(...)it is the individual's belief in an obligation of reciprocity that constitutes a contract" 22 (ROUSSEAU, 1989, pp. 123 - 124). Em outras palavras, é a percepção do indivíduo que influencia a formação do Contrato Psicológico, o qual deve ser contratado apenas por indivíduos, não devendo ser estabelecido por entidades abstratas como as organizações. Além disso, é importante notar que o contrato, sob a perspectiva de Rousseau, não se caracteriza fortemente pela mutualidade, conforme a perspectiva clássica.

Para os trabalhos anteriores a Rousseau (1989), a formação dos Contratos Psicológicos estava vinculada à formação das expectativas. Para a autora, os Contratos Psicológicos são formados "by the individual's perceptions of their own and the organization's behavior in terms of explicit verbal and written promises or implicit promises arising from consistent and repeated patterns of behavior by parties to the contract."23 (CONWAY E BRINER, 2005, p. 14). A expectativa, neste caso, passa a ser uma possível conseqüência da formação de um Contrato Psicológico.

\footnotetext{
${ }^{19}$ É uma crença individual independente dos termos e condições das trocas recíprocas estabelecidas entre o indivíduo e a outra parte.

${ }^{20}$ As questões-chave aqui incluem a crença de que uma promessa foi feita e uma contrapartida oferecida em troca, ligando as partes a alguns conjuntos de obrigações recíprocas.

${ }^{21}$ Nos olhos de quem vê.

${ }^{22}$ É a crença do indivíduo em uma obrigação de reciprocidade que constitui um contrato.

${ }^{23}$ pela percepção do indivíduo a respeito de seu comportamento e da organização em termos de promessas verbais e escritas, ou implícitas decorrentes de promessas consistentes e repetidas dos padrões de comportamento das partes do contrato.
} 
Dadas as principais diferenças históricas da evolução do tema, a seção seguinte discutirá em profundidade as diferentes conceituações acerca dos Contratos Psicológicos, bem como seus pontos críticos, a fim de chegar a um entendimento sobre o conceito.

\subsection{O conceito de Contratos Psicológicos}

Conforme discutido na seção anterior, o conceito de Contratos Psicológicos é antigo, e sua utilização em pesquisas organizacionais tem ganhado expressão, principalmente, a partir do trabalho seminal de Denise Rousseau em 1989. Entretanto, sabe-se que os trabalhos produzidos anteriormente (Menninger (1958); Argyris, (1960); Levinson (1963); Schein $(1965 ; 1980))$ impulsionam as discussões mais recentes. Estes trabalhos, apesar de referiremse ao mesmo conceito, utilizavam-no para descrever diferentes fenômenos, como é possível observar nas definições expostas na seção 3.1. Os trabalhos que mais influenciaram uma parte da comunidade acadêmica atual sobre o conceito de Contrato Psicológico foram os de Levinson et.al. (1963) e Schein (1965 e 1980). Ambos partiram da idéia central de que tais contratos compõem as expectativas mútuas entre indivíduos e organizações, e que eles estão fortemente calcados na percepção de troca na relação de trabalho. Tal legado fora seguido por diferentes autores. A seguir, estão expressos os conceitos propostos por alguns deles:

An implicit contract between an individual and his organization which specifies what each expect to give and receive from each other in the relationship. ${ }^{24}$ (KOTTER, 1973, p. 92).

The psychological contract is an individual's set of reciprocal expectations concerning one's obligations (what the employee owes) and entitlements (what the employer owes).This concept is rooted in a social theory, which argues that people form relationship in order to give and receive things of value. (...) psychological contracts exist in the eye of the observer (...) employment is a psychological contract in which the employee fulfills his or her responsibilities with the expectation that the employer will reciprocate. ${ }^{25}$ (BUCHHOLTZ e KIDDER, 2002, p. 562).

\footnotetext{
${ }^{24}$ Um contrato implícito entre um indivíduo e sua organização, que especifica o que cada um espera dar e receber na relação.

${ }^{25}$ O Contrato Psicológico individual é um conjunto de expectativas recíprocas relativas a uma obrigação (o que o empregado deve) e direitos (o que deve o empregador). Este conceito está enraizado na teoria social, que argumenta que as pessoas formam relacionamentos a fim de dar e receber coisas de valor. (...) contratospsicológicos existem nos olhos do observador (...) emprego é um Contrato Psicológico no qual o trabalhador cumpre as suas responsabilidades com a expectativa de que o empregador terá que agir reciprocamente.
} 
The psychological contract is defined as the set of reciprocal expectations between an individual and the organization. ${ }^{26}$ (HERRIOT, 1995, p. 1).

Como é possível observar a partir destas definições, forma-se uma corrente acadêmica fortemente pautada na idéia de que os Contratos Psicológicos, para existirem, dependem dos pilares expectativa e mutualidade. Esta corrente de pensamento tem sido bastante criticada por aqueles que seguem a segunda corrente de definição dos Contratos Psicológicos, liderada por Rousseau (1989; 1990; 1995); Rousseau e Parks (1993); Robinson (1996); Herriot e Pemberton (1997); Morinson e Robinson (1997) entre outros.

De acordo com estes autores, os Contratos Psicológicos definem-se como:

The term psychological contract refers to an individual 's belief regarding the terms and conditions of a reciprocal exchange agreement between the focal person and another party. Key issues here include the belief that a promise has been made and a consideration offered in exchange for it, binding the parties to some set of reciprocal obligations. ${ }^{27}$ (Rousseau, 1989, p. 123).

The psychological contract is individual beliefs, shaped by organization, regarding the terms of an exchange agreement between the individual and their organization. ${ }^{28}$ (Rousseau, 1995, p. 9).

The perceptions of both parties to the employment relationship, organization and individual, of the obligations implied in the relationship. ${ }^{29}$ (Herriot $\mathrm{e}$ Pemberton, 1997, p. 45)

An employee's beliefs about reciprocal obligations between that employee and his or her organization, where these obligations are based on perceived promises and are not necessarily recognized by agents of the organization. ${ }^{30}$ (Morrinson e Robinson, 1997, p. 229)

\footnotetext{
${ }^{26}$ O Contrato Psicológico é definido como um conjunto de expectativas entre o indivíduo e a organização.

${ }^{27} \mathrm{O}$ termo Contrato Psicológico refere-se a uma crença individual independente dos termos e condições de um acordo de troca recíproco entre a pessoa focal e a outra parte. A questão-chave aqui inclui a crença de que uma promessa foi feita e uma contrapartida oferecida em troca, ligando as partes a alguns conjuntos de obrigações recíprocas.

${ }^{28}$ O Contrato Psicológico é uma crença individual, moldada pela organização, independente dos termos de troca acordados entre o indivíduo e a organização.

${ }^{29}$ As percepções de ambas as partes da relação de trabalho, organização e indivíduo, sobre as obrigações implícitas a relação.

${ }^{30}$ Uma crença do empregado a respeito das obrigações recíprocas entre empregador e empregado, sendo que estas obrigações estão baseadas na percepção de promessa e não são necessariamente reconhecidas pelos agentes da organização.
} 
Os principais pilares destas definições, que significaram um divisor de águas na conceituação dos Contratos Psicológicos, liderados por Rousseau (1989), são o caráter promissório e o foco no nível individual na formação do contrato, pois conforme citado na seção 3.1, o Contrato Psicológico está "in the eye of the beholder".

As promessas se tornaram o termo preferido por muitos autores (representantes da segunda corrente) ao definir Contratos Psicológicos, pois de acordo com Conway e Briner (2005) estas parecem ser mais contratuais, enquanto expectativas parecem ter um significado mais genérico e, ao mesmo tempo, somente fazem parte do Contrato Psicológico quando estão baseadas em uma promessa percebida. Ao visitar a definição de expectativa e promessa, é possível perceber as diferenças conceituais entre os termos que, por sua vez, implicam em uma diferenciação do conceito de Contrato Psicológico. (CONWAY e BRINER, 2005, p. 23).

Promessas, segundo Rousseau e Parks (1993), referem-se ao comprometimento de se fazer algo. É a garantia de que algo será feito. Esta garantia, por sua vez, gera a obrigação de cumprimento da promessa que, se não for realizada, produz "uma resposta mais intensa (...) do que aquela gerada pela não realização das expectativas." (SHAPIRO e KESSLER, 2000, p.906, tradução nossa). Como expressa Rousseau (1989):

Failure to meet the terms of a psychological contract produces more than just unmet expectations. It signals a damage to the relationship between the organization and the individual. Underlying a psychological contract is trust, which develops from a belief that contributions will be reciprocate and that a relationship exists where actions of one party are bound to those of another. "A damaged relationship is not easily restored." 31 (ROUSSEAU, 1989, p. $128)$.

Expectativas, por sua vez, são "uma crença momentânea a respeito da probabilidade de que uma ação em particular será seguida de um resultado particular" (VROOM, 1964, p. 17). Ou seja, estão baseadas em uma crença provável a respeito de um futuro evento. A palavra central neste caso é a probabilidade. De acordo com Rousseau e Parks (1993), enquanto todas as promessas envolvem expectativas, estas últimas não necessariamente envolvem um elemento promissório.

\footnotetext{
${ }^{31}$ A incapacidade de cumprir os termos de um Contrato Psicológico produz mais do que expectativas não satisfeitas. Sinaliza danos ao relacionamento entre a organização e o indivíduo. Subjacente a um Contrato Psicológico está a confiança, que se desenvolve a partir de uma crença de que as contribuições serão recíprocas e que existe uma relação em que as ações de uma parte estão vinculadas às da outra. "Um dano em uma relação não é facilmente restaurado."
} 
De acordo com a análise de Conway e Briner (2005), promessas estão enraizadas em um contrato e seus participantes esperam que este seja realizado simplesmente pelo fato de uma das partes ter comunicado ou se comportado de determinada maneira, de modo a permitir que a outra acredite que uma promessa tenha sido feita. Expectativas, como aquelas baseadas em crenças prováveis, são normalmente constantes e, de alguma forma, dispositivos estáveis de nossa experiência consciente. Os seres humanos geralmente tendem a esperar que algumas coisas tenham maior probabilidade de acontecer em detrimento de outras. Entretanto, quando um indivíduo acredita que uma promessa tenha sido feita, tende a antecipar a garantia de que tais promessas serão cumpridas, agindo de modo a checar se a promessa foi ou não feita, planejando o que será feito assim que esta for realizada e, principalmente, buscando meios para cumprir a contrapartida do contrato. Em outras palavras, o indivíduo que acredita em uma promessa não trabalha com probabilidades, mas sim com fatos concretos. (CONWAY e BRINER, 2005, pp. 24-26), como reforça a afirmação de Rousseau “Although obligations are a form of expectation, not all expectations held by a person need to be promissory or entail a belief in mutuality or reciprocity. "32 (ROUSSEAU, 1998, p. 668).

Assim sendo, por entender que o contrato, por natureza, contém o caráter promissório, e não apenas a crença em uma probabilidade, a corrente teórica seguida neste trabalho será a de Rousseau. Ao longo das próximas discussões, serão tratadas críticas em relação à construção teórica desta autora e seus seguidores, bem como uma nova definição de Contratos Psicológicos.

\subsection{A corrente contemporânea do Contrato Psicológico}

O trabalho Psychological and implied contracts in organizations de Denise Rousseau, publicado em 1989, foi um marco na discussão do tema Contratos Psicológicos porque contribuiu de forma substancial para a elaboração do construto. Entendendo que contratos escritos ou não estão sujeitos a diferentes percepções acerca da mensagem em si, por considerar que a forma como as mensagens são expressas pode estar fragmentada, ou ainda que estas estejam sujeitas aos limites cognitivos, aos diferentes referenciais individuais e sociais e à própria complexidade das interações sociais, a autora afirma que a subjetividade é

\footnotetext{
${ }^{32}$ Embora as obrigações sejam uma forma de expectativa, nem todas as expectativas de uma pessoa precisam ser
} promissórias ou implicar em uma crença na reciprocidade. 
um fator extremamente relevante na discussão de qualquer contrato estabelecido entre diferentes partes. Tal subjetividade advém do próprio contexto sócio-econômico vivido pela sociedade, conforme explicita MacNeil (1985):

Trends in Law appear to support enforcement of nonexplicit or implied agreement, recognizing that relationships increasingly are becoming the dominant form of economic activity and planning in modern society. ${ }^{33}$ (MACNEIL, 1985, p. 62).

A existência de subjetividade nas relações contratuais torna importante a discussão de seu papel nas relações de trabalho. Segundo o autor supracitado, a subjetividade dos contratos na perspectiva de cada uma das partes implica que todos os contratos, escritos ou não, são fundamentalmente psicológicos e, por isso, estão no olhar de quem os vê. A partir deste entendimento é que Rousseau define os Contratos Psicológicos como:

an individual 's belief regarding the terms and conditions of a reciprocal exchange agreement between the focal person and another party. Key issues here include the belief that a promise has been made and a consideration offered in exchange for it, binding the parties to some set of reciprocal obligations. ${ }^{34}$ (ROUSSEAU, 1989, p. 123).

De acordo com a autora, quando um indivíduo percebe que suas contribuições geram uma obrigação de reciprocidade por parte da organização, o Contrato Psicológico emerge. Acreditar que a reciprocidade ocorrerá pode ser um precursor do desenvolvimento do Contrato Psicológico, porque é a crença do indivíduo na obrigação de reciprocidade que o constitui. É importante salientar que esta crença é unilateral porque, conforme expresso no parágrafo anterior, o contrato está no olhar de quem os vê e, por isso, é subjetivo.

Guest (1998), Conway e Briner (2005) e Arnold (1996) criticam o posicionamento de Rousseau quanto à questão da uniteralidade (ou não existência de mutualidade) e subjetividade do conceito Contrato Psicológico. Para estes autores, assim como os contratos legais somente são estabelecidos entre duas partes e com o consentimento das mesmas e, por isso, são mútuos, os Contratos Psicológicos, na definição de Rousseau, estão sujeitos à

\footnotetext{
${ }^{33}$ Tendências na Lei parecem suportar a execução de acordos não explícitos ou implícitos, reconhecendo que os relacionamentos estão se tornando a forma dominante da atividade econômica e planejamento da sociedade moderna.

${ }^{34}$ É uma crença individual independente dos termos e condições de troca estabelecidos entre uma pessoal focal e a outra parte. A questão-chave aqui inclui a crença de que uma promessa foi feita e uma contrapartida foi oferecida em troca, ligando as partes em um conjunto de obrigações recíprocas.
} 
arbitrariedade. Ao considerar que o Contrato Psicológico está nos olhos de quem o vê, cada parte do contrato acredita que haja um acordo, mas não há necessidade de haver um real acordo em que as partes tenham o mesmo entendimento do contrato. Os contra-argumentos à critica surgem, como expressam Robinson e Rousseau (1994):

Note that these are beliefs or perceptions regarding promises or acceptance. Each party believes that both parties have made promises and that both parties have accepted the same contract terms. However this does not necessarily mean that both parties share a common understanding of all contract terms. Each party only believes that they share the same interpretation of the contract. ${ }^{35}$ (Robinson e Rousseau, 1994, p.246).

Macneil (1985) reforça tal argumentação ao dizer que todos os contratos, escritos ou não, são essencialmente subjetivos porque seus termos estão sujeitos à interpretação subjetiva de cada indivíduo.

Rousseau (1998) afirma que a interpretação de Guest (1998), Arnold (1996) e Conway e Briner (2005), ao dizer que o conceito de Contrato Psicológico definido por ela não considera os aspectos de mutualidade, está incorreta. Para a autora, a questão-chave acerca deste tema é que a percepção de mutualidade e não a mutualidade de fato é que permite o surgimento do Contrato Psicológico. (ROUSSEAU, 1998, p. 666; ROUSSEAU, 1995, pp.2021).

Guest (1998) e Conway e Briner (2005) vão mais longe com as críticas em relação ao trabalho desenvolvido por Rousseau.

Conway e Briner (2005) expõem que o Contrato Psicológico é uma questão de troca. Ou seja, refere-se a um acordo de troca percebido entre as partes, em que a reciprocidade precisa ocorrer. Se esta reciprocidade não ocorre, ela descaracteriza o contrato. (CONWAY e BRINER, 2005, p.30). Neste sentido, os autores questionam a validade do Contrato Psicológico como contrato. Rousseau (1998), sete anos antes já havia respondido a este questionamento pautando-se nas discussões entre as escolas de direito e das ciências sociais, que aceitam uma a existência da outra, e utilizam seus conceitos sobre contratos para o desenvolvimento de suas práticas.

\footnotetext{
${ }^{35}$ Nota-se que são crenças ou percepções relativas a promessas ou aceitação. Cada uma das partes considera que ambas as partes fizeram promessas e que ambas as partes aceitaram as mesmas condições contratuais. Contudo, isto não significa que ambas as partes necessariamente compartilham de um mesmo entendimento das cláusulas contratuais. Cada uma das partes só acredita que partilham da mesma interpretação do contrato.
} 
Scholars on the subject have not equated psychological contract with a legal contract; the confusion between the two is more often characteristic of lay people who first encounter the concept. In contrast, scholars typically take pain to differentiate one from other (e.g. McLean Parks and Shcmedemann, 1994). Moreover, legal scholars and social scientists cite one another in their efforts to explain how people think about their agreements (...).It is the social group that creates the rules upon which such judgments are based. Note that (...) it is sociology in general, not law per se, that defines obligations and entitlements. Scholars interested in psychological contracts have reached beyond the answers sociology can provide to include the psychological process that influence the interpretation of promises exchanged between parties. ${ }^{36}$ (ROUSSEAU, 1998, p. 666).

Um bom exemplo disto é que muitos acadêmicos das escolas de direito utilizam a teoria de Contratos Psicológicos para explicar como pessoas interpretam contratos escritos. Ademais, conforme citado anteriormente nesta seção, Macneil (1985) afirma que todos os contratos legais são fundamentalmente psicológicos. A reciprocidade ocorre no campo da percepção de obrigação de reciprocidade, o que não necessariamente implica em uma reciprocidade de fato. Se não fosse assim, o Contrato Psicológico não se diferenciaria do contrato na forma legal, que, "na lei, (...) cria e define direitos e obrigações a serem implementados entre as partes que intencionalmente criaram um relacionamento." (SPINDLER, 1994, p. 326). É importante lembrar que, sob a definição de Rousseau (1989), o Contrato Psicológico ocorre exclusivamente no nível individual, e não no nível relacional.

Outro aspecto criticado por Guest (1998), Conway e Briner (2005) refere-se às partes do Contrato Psicológico. Segundo Guest (1998):

The employment contract will be signed between employee and an agent of the organization. The psychological contract faces the often-cited difficulty of defining what is meant by the organization. Rousseau (1995) devotes some space to analysis of 'agents' but fails to get round the problem, simply because there are multiple agents for the organization and they may be

\footnotetext{
${ }^{36}$ Estudiosos sobre o assunto ainda não equacionaram o Contrato Psicológico com o legal; a confusão entre os dois é mais característica de leigos que primeiramente entram em contato com o conceito. Em contrapartida, estudiosos normalmente sofrem para diferenciar um conceito de outro (por exemplo, McLean Parques e Shcmedemann, 1994). Além disso, estudiosos do direito e cientistas sociais citam uns os outros, em seus esforços para explicar como as pessoas pensam sobre os seus acordos. (...) É o grupo social que cria as regras pelas quais essas decisões se baseiam. Note-se que (...) é a sociologia em geral, não pela lei em si, que define as obrigações e direitos. Estudiosos interessados em Contratos Psicológicos ultrapassaram as respostas que a sociologia pôde fornecer para incluir os processos psicológicos que influenciam a interpretação das promessas trocadas entre as partes.
} 
'offering' different and sometimes competing contracts. ${ }^{37}$ (GUEST, 1998, p. 652).

Conway e Briner (2005) reiteram a discussão, perguntando quem representa a organização ou o empregador na contratação psicológica. Enquanto a maioria das definições enfatiza o empregado como o principal contratante do Contrato Psicológico, uma área de extenso debate preocupa-se se, de fato, a outra parte contratante, a organização, pode ou possui um Contrato Psicológico. (CONWAY e BRINER, 2005, p. 33).

A conceituação clássica sobre o tema (Argyris, 1960; Levinson et.al., 1963; Schein, 1965) e algumas das definições recentes (Herriot e Pemberton, 1997; Shapiro e Kessler, 1998; Guest, 1998) consideram que a outra parte contratante é o empregador, representado por agentes como gerentes de linha ou seniores, e por características de grupos ou organizações como a cultura. Para Rousseau e seus simpatizantes (Rousseau, 1989; 1995; Morrinson and Robinson, 1997, por exemplo), entidades abstratas não podem possuir Contratos Psicológicos. Apenas os representantes de organizações, ou agentes, poderiam tê-lo. Entretanto, conforme expõem Conway e Briner (2005) o problema chave na posição de Rousseau é que as definições de Contratos Psicológicos estabelecem que empregados devem tratar a organização como se esta possuísse um Contrato Psicológico. (CONWAY e BRINER, 2005, p. 33).

Guest (1998) complementa dizendo que a solução do problema dos 'agentes' adotada por Rousseau e outros pesquisadores contemporâneos acaba por antropomorfizar a organização, tornando-a um indivíduo e, assim, definindo o Contrato Psicológico somente em termos da percepção do empregado. (GUEST, 1998, p. 652).

Segundo Rousseau (1989), as organizações tornam-se parte integrante do Contrato Psicológico por meio de seus representantes, que podem ser os proprietários ou mesmo representantes da organização. Ainda há de se considerar os valores, as práticas organizacionais, as comunicações, entre outros. O que de fato ocorre é que indivíduos entram em contato com pessoas que lhes transmitem uma série de informações, mensagens, valores e o que o indivíduo percebe como promessa é que comporá o Contrato Psicológico. Então, pessoas, mensagens, práticas organizacionais etc. podem apenas ser caracterizadas como meios para a formação do Contrato Psicológico e não como a outra parte contratante.

\footnotetext{
${ }^{37} \mathrm{O}$ contrato de trabalho será assinado entre o empregado e um agente da organização. O Contrato Psicológico enfrenta a freqüentemente citada dificuldade de definir o que de fato a organização quer dizer. Rousseau (1995) dedica algum espaço para a análise dos 'agentes', mas não para contornar o problema, simplesmente porque existem múltiplos agentes na organização e eles podem oferecer diferentes e, por vezes, contratos concorrentes.
} 
Conforme explicado anteriormente nesta seção, o Contrato Psicológico não equivale a um contrato legal. Ele é um produto que advém da interação social.

Muitas definições de Contratos Psicológicos consideram que as crenças de promessas percebidas são formadas ou moldadas pela interação entre o empregador e o empregado. Em outras palavras, as crenças formadas em outras relações de trabalho prévias não são consideradas parte do Contrato Psicológico. Entretanto, segundo Conway e Briner (2005), pesquisadores discordam sobre a extensão em que o Contrato Psicológico é moldado por fatores externos ou internos à organização. Pelas definições clássicas de Levinson et. al. (1963) e Schein (1980), os Contratos Psicológicos são consideravelmente moldados por experiências que antecedem a relação entre empregador e empregado. (Levinson et.al., 1963). Entretanto, conceituações mais recentes como as de Rousseau $(1989 ; 1995)$ e seus seguidores dão menos ênfase à influência de experiências antecessoras na relação atual de trabalho e, por sua vez, na formação do Contrato Psicológico, e consideram que é da relação com a atual organização e seus agentes que o Contrato Psicológico emerge. Mas Rousseau (1998) afirma que ninguém ainda pesquisou sobre as origens do Contrato Psicológico individual, e Conway e Briner (2005), sete anos depois, reafirmam tal posicionamento ao colocarem como desafio para os pesquisadores, dentre outros, responder de onde surgem os Contratos Psicológicos, quais são os fatores que influenciam tais contratos, quais aspectos inerentes ao indivíduo contribuem para sua formação do Contrato Psicológico.

Neste sentido, Meckler, Drake e Levinson (2003) abrem um amplo debate sobre a omissão dos fundamentos teóricos da psicologia nos trabalhos sobre Contratos Psicológicos, que para eles abrangem os mecanismos comportamentais do processo de contratação, como por exemplo, a teoria da agência, confiança, justiça para explicar as reações dos indivíduos na violação do Contrato Psicológico. Mas tais discussões afastaram-se demais da psicologia clínica, campo de conhecimento base para o entendimento dos Contratos Psicológicos.

De acordo com o trabalho Putting psychology back into psychological contracts, Meckler, Drake e Levinson (2003) colocam que o ambiente de trabalho é um espaço em que os empregados podem canalizar suas necessidades de afeto, agressão, dependência e, também, conquistar seu ideal de ego. Na medida em que os objetivos organizacionais e do empregado estejam razoavelmente alinhados, estes últimos estarão naturalmente motivados a trabalhar para preencher estas necessidades psicológicas.

A definição atual de Contratos Psicológicos, conforme discutido nesta seção, está pautada em dois pilares básicos: o das expectativas e o das promessas. Expectativas são 
crenças momentâneas conscientes, assim como a percepção de uma promessa também é consciente, ainda que a percepção ou expectativa surja de um processo de interação social não escrito, mas entendido.

Segundo Meckler, Drake e Levinson (2003):

Although contemporary psychological contract literature insists on speaking primarily about conscious expectations [or perceptions] in the employment relationship, the original clinically based conceptualization focused on understanding what are often unconscious needs for affection, dependency, and aggression and the personal identity or ego ideals that drive motivation and human behavior. ${ }^{38}$ (MECKLER, DRAKE e LEVINSON, 2003, p. 218).

A revisão realizada para este trabalho indica que as pesquisas atuais sobre o tema Contratos Psicológicos constróem errôneamente, bem como suprimem e/ou ignoram as necessidades psicológicas relevantes para a discussão dos Contratos Psicológicos. Isso porque, talvez, muitos dos autores não entendam que os aspectos sociais e econômicos dos Contratos Psicológicos diferem dos elementos psicológicos, conforme exemplificam Meckler, Drake e Levinson (2003):

(...) the social aspect describes acceptable and unacceptable behaviors that may be used to satisfy psychological needs. However, a social contract is not an agreement that employee will be placed in situations and/or given training that will help them fill these needs. Economic components offer compensation in forms that may help satisfy an employee's desires (a big Office, a Nice salary, an important title), but it will not cover other issues that are critical to an individual's achievement of their ego ideal or other psychological needs. ${ }^{39}$ (MECKLER, DRAKE e LEVINSON 2003, p. 218).

As necessidades citadas por estes autores são em sua grande maioria inconscientes, possuem grande poder sobre as ações e percepções dos indivíduos e são resultado parcial das

\footnotetext{
${ }^{38}$ Embora a literatura contemporânea de Contrato Psicológico insista em falar principalmente sobre a consciência das expectativas [ou percepções] na relação empregatícia, o conceito clínico original centrou-se em compreender quais são as necessidades inconscientes de afeto, dependência e agressão, e da identidade pessoal ou ideais de ego que impulsionam a motivação e o comportamento humano.

${ }^{39}$ (...) O aspecto social descreve comportamentos aceitáveis e inaceitáveis que podem ser utilizados para satisfazer necessidades psicológicas. Entretanto, um contrato social não é um acordo segundo o qual o trabalhador será colocado em situações que irão ajudá-lo a preencher essas necessidades. Componentes econômicos oferecem compensações que podem ajudar a satisfazer um desejo do empregado (um grande escritório, um bom salário, um importante título), mas não vai abranger outras questões que são fundamentais para a realização do ideal de ego do indivíduo ou outras necessidades psicológicas.
} 
idiossincrasias do nível individual. Tais idiossincrasias, bem como percepções individuais, sequer são relacionadas à personalidade dos indivíduos quando o assunto é Contrato Psicológico.

O trabalho de Rousseau (1995) discute, breve e superficialmente, a inconsciência ao tratar os Contratos Psicológicos quando aborda as estruturas ou modelos mentais de Foa e Foa (1974). Para estas últimas, o entendimento humano sempre passa pelo filtro das estruturas mentais individuais, que permitem que cada um de nós entenda uma determinada informação ou conhecimento de uma maneira diferente, o que, por sua vez, torna a percepção do Contrato Psicológico algo estritamente individual.

Raja, Johns e Ntalianis (2004), partindo da ausência de trabalhos científicos relacionando personalidade e Contratos Psicológicos, examinam a relação entre a personalidade do empregado e o tipo de Contrato Psicológico, a percepção de ruptura de contrato e sentimento de ruptura do Contrato Psicológico. Apesar de trazer resultados bastante significativos no que se refere ao impacto da personalidade nos Contratos Psicológicos, estes autores não entram na discussão sobre os aspectos inconscientes dos indivíduo. O mesmo faz DelCampo (2007) ao examinar o impacto das diferenças individuais em reportes de ruptura do Contrato Psicológico.

A ausência de uma ampla discussão das raízes da psicologia nos trabalhos publicados sobre Contratos Psicológicos contribui para a não identificação do que origina o Contrato Psicológico, bem como quais fatores e aspectos individuais contribuem na formação do Contrato Psicológico, questionamento colocado tanto por Rousseau (1998) quanto por Conway e Briner (2005).

Assim, esta tese, ao propor o exame do impacto que os tipos psicológicos têm na leitura dos Contratos Psicológicos, corrobora para o entendimento de como os aspectos individuais afetam os conteúdos dos Contratos Psicológicos. Então, faz-se necessária uma explanação sobre o conteúdo dos Contratos Psicológicos e de sua categorização.

\subsection{O conteúdo e a categorização dos Contratos Psicológicos}

Conforme mencionado na seção 3.1, o Contrato Psicológico existe no nível individual, na forma de uma crença individual dos termos de troca de um relacionamento. Tais termos, ou 
conteúdo do Contrato Psicológico, expressam o que os indivíduos acreditam que lhes foi prometido, e que promessas fizeram ao seu empregador. "É importante notar que o conteúdo do Contrato Psicológico não é o que o empregado de fato dá e recebe de seu empregador, na verdade são as promessas explícitas e implícitas [percebidas] em torno da troca." (CONWAY e BRINER, 2005, p. 37, tradução nossa).

Apesar das pesquisas sobre o conteúdo dos Contratos Psicológicos serem as mais numerosas depois do tema ruptura dos Contratos Psicológicos, na verdade poucas têm sido conduzidas sobre ele.

Os trabalhos mais expressivos que tratam do conteúdo dos Contratos Psicológicos são de Rousseau (1990), Guzzo, Noonan e Elron (1994) e Herriot, Manning e Kidder, (1997), Rousseau e Tijoriwala (1998). Esses autores, no entanto, restringiram suas investigações de conteúdo para uma limitada cesta de promessas percebidas pelos empregados que consideraram mais importantes.

Rousseau (1990) gerou conteúdos de promessas a partir de uma pesquisa com 224 graduandos de um curso de MBA que tinham recentemente aceitado ofertas de trabalho. Eles foram questionados a respeito de suas percepções do processo de recrutamento/seleção, intenções e motivações. Como resultado, foram identificadas, segundo a visão dos alunos, as seguintes obrigações do empregador: promoção, alta remuneração, pagamento associado ao nível de performance, treinamento, segurança do trabalho, desenvolvimento na carreira e suporte para os problemas pessoais; e as seguintes obrigações do empregado: trabalhar horasextras, lealdade, iniciativa para realizar tarefas não requeridas no trabalho, notificação adiantada quando aceitar emprego em outro lugar, disposição para aceitar transferências, recusa em oferecer suporte aos competidores do empregador, proteção em relação às informações sigilosas, trabalhar no mínimo dois anos na organização. (ROUSSEAU, 1990).

Guzzo, Noonan e Elron (1994), em uma pesquisa com gestores expatriados, geraram 43 itens que deveriam representar o conteúdo do Contrato Psicológico. Entretanto, os autores falharam ao trabalhar a medida que representaria o Contrato Psicológico, pois os mesmos não questionaram as promessas feitas pela organização, e sim, o que eles achavam que a organização deveria prover. Como notou Arnold (1996), o termo 'deveria' não é consistente com a natureza promissória do Contrato Psicológico.

Conforme as palavras de Conway e Briner (2005), provavelmente o trabalho mais meticuloso a respeito do conteúdo dos Contratos Psicológicos (CONWAY E BRINER, 2005, 
p. 40) foi realizado por Herriot, Manning e Kidd (1997), que exploraram ambas as perspectivas, ou seja, a do empregado e a do empregador. Para capturarem a perspectiva do empregador, gestores da organização foram requisitados a falar sobre a mesma. $\mathrm{O}$ estudo utilizou a técnica do incidente crítico, perguntando sobre as ocasiões em que a organização e o empregado falharam ou excederam as expectativas. $\mathrm{O}$ estudo assumiu que para uma expectativa ser alcançada, ou não, deve haver uma promessa subjacente. A amostra trabalhada foi a de 184 empregados e 184 gestores britânicos (representantes da organização). Os resultados encontrados foram melhor apresentados por Conway e Briner (2005):

Tabela 1: O conteúdo dos Contratos Psicológicos no Reino Unido

\begin{tabular}{|c|c|c|}
\hline \multirow{2}{*}{ What employees can exoect from orcanization } & \multicolumn{2}{|c|}{ Q o incidents fall 19 into item categors } \\
\hline & Employee's perspertve & Oyganizatiun's perspective \\
\hline Prowiding adequate training & 9.6 & 8.3 \\
\hline $\begin{array}{l}\text { Faimess in selection, appraisal, prcrnotion, } \\
\text { anc recuncancy prucecures }\end{array}$ & 10.8 & 129 \\
\hline Mectinc personal and tarrily nowes & 5.7 & 4.8 \\
\hline Corsuitution on matters aifecting erriployed & 5.3 & 4.8 \\
\hline Discretion in how employees do their job & 5.3 & 2.0 \\
\hline $\begin{array}{l}\text { Humanity, acting in a responsib/e unc suppotive } \\
\text { 'way towerds employes }\end{array}$ & 7.3 & 14.3 \\
\hline feemgnition tor special cur tribstions & 4.2 & 10.8 \\
\hline Safe anc conçenial entironment & 15.0 & 3.7 \\
\hline ustice in the applicat on of rules and disripline & 5.4 & 4.2 \\
\hline $\begin{array}{l}\text { Fay ec uitable with respect to market and } \\
\text { across the cumpony }\end{array}$ & 11.9 & 6.3 \\
\hline benefits-aimess and consistency of & 9.6 & 164 \\
\hline Providing ob senurity as much as is positie e & 9.6 & 6.3 \\
\hline \multicolumn{3}{|l|}{ What organization can expect from employees } \\
\hline To work contracted hours & 32.1 & 28.1 \\
\hline In do a govid jos in terms of quantity and quality & 19.4 & 22.3 \\
\hline To be hionest & 15.2 & 16.9 \\
\hline $\begin{array}{l}\text { Loyaity-staying with the organizatian and } \\
\text { putting ts interests first }\end{array}$ & 4.2 & 11.6 \\
\hline Treating the organization's, pmperty respectfully & 8.4 & 3.7 \\
\hline Self-prasentetion-dress ng anc behaving correctly & 10.5 & 5.8 \\
\hline $\begin{array}{l}\text { Foxibility -wil line to go tepond job descriotion } \\
\text { when required }\end{array}$ & 10.1 & 116 \\
\hline
\end{tabular}

Fonte: Conway e Briner, 2005, p.41.

É interessante observar algumas particularidades apontadas na Tabela 1. Nos conteúdos Humanity, Recognition, Safe, Pay, Benefits, Loyalty, Treating Organization's Property Respectfully, Self-presentation, Discretion, há uma notável diferença entre os percentuais de incidentes sob a perspectiva do empregado e da organização. Isto provavelmente deve ocorrer pelo fato da pessoa que representa a organização estar em posição de chefia. Os gestores de pessoas assumem papéis diferenciados na organização e, 
normalmente, são regidos sob uma visão de empresa e relação empregatícia diferente da do empregado. Por exemplo, no conteúdo "humanidade", o percentual de incidente é menor sob a perspectiva do empregado do que a da organização. Isso provavelmente ocorre porque o gestor assume para si responsabilidades em relação ao empregado.

No Brasil, desenvolveu-se um trabalho de natureza qualitativa e quantitativa, realizado com sete empregados de duas consultorias que se encontram entre as cinco maiores consultorias do mundo. O conteúdo do Contrato Psicológico levantado foi semelhante ao das pesquisas supracitadas, exceto : aceitação da diversidade, aprendizado intenso, exposição profissional, acesso (a poder, clientes, informações privilegiadas, por exemplo) e status social e profissional. (MENGON, 2004; MENEGON e CASADO, 2005; MENEGON e CASADO, 2006).

É importante notar que os estudos mencionados anteriormente trabalham especificamente medidas de conteúdo individual, como escalas e termos representativos do Contrato Psicológico. Entretanto, essas não são as únicas medidas de conteúdo utilizadas nas pesquisas.

Segundo Rousseau e Tijoriwala (1998), “as avaliações orientadas para conteúdo endereçam os termos e obrigações recíprocas que caracterizam um Contrato Psicológico individual. (...) As avaliações de conteúdo diferem se elas focam nas partes do Contrato Psicológico (ex. termos) ou em um composto mais amplo (ex., caracterizações sumárias do conteúdo do contrato)" (ROUSSEAU E TIJORIWALA, 1998, p. 685, tradução nossa). As medidas quantitativas e padronizadas do conteúdo do contrato podem ser operacionalizadas de três maneiras: como termo, compostos e classificações nominais, conforme a figura 1: 

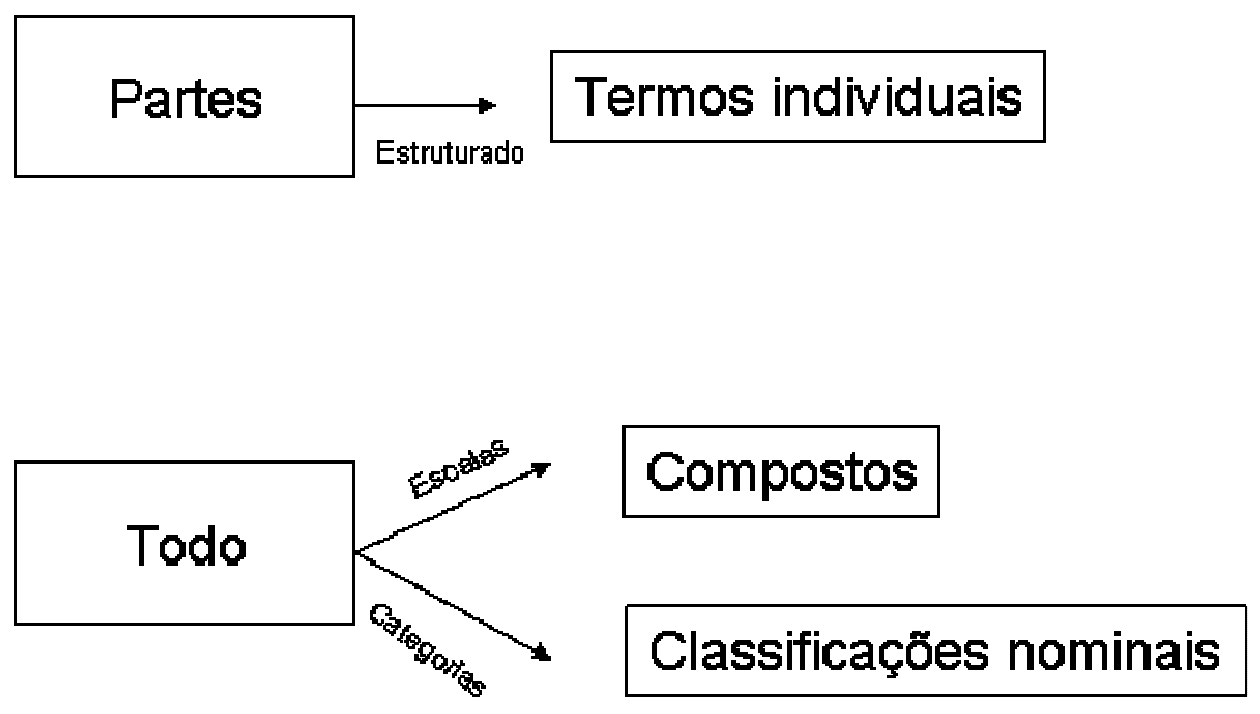

Figura 1: Conteúdos do Contrato Psicológico

Fonte: adaptado de Rousseau e Tijoriwala, 1998, tradução nossa.

a) Termos: são as obrigações que os indivíduos percebem que devem (ex.: trabalho duro, aceite de transferência) e seus empregadores devem em retorno (ex.: promoção, suporte a problemas pessoais). Como indicado na figura 1, os termos representam partes de um composto mais amplo do contrato. (ROUSSEAU E TIJORIWALA, 1998).

b) Composto de termos: "é um conjunto de obrigações combinadas para formar um modelo mais amplo de contrato (ex.: parceria - forte obrigação mútua numa perspectiva ampla) (...) medido no nível de termo (...) e analisado em um nível agregado pela criação de um index baseado na análise de clusters individuais pela combinação das obrigações do empregador e empregado. (...) compostos são evidenciados como medidas sintetizadas do conteúdo de um contrato global baseadas numa escala de termos contratuais individuais." (ROUSSEAU E TIJORIWALA, 1998, p. 686-7).

c) Classificação nominal: são tipologias pelas quais os respondentes indicam qual categoria reflete seu entendimento a respeito de uma relação empregatícia. A classificação nominal apresenta a vantagem de especificar o tipo de relacionamento entre empregador e empregado, contendo uma mistura de conteúdo de contrato com adjetivos que descrevem o contrato, como, por exempo, o termo performance e os adjetivos explícito/implícito. Sua falha está em especificar os termos específicos do Contrato Psicológico. (ROUSSEAU E TIJORIWALA, 1998). Por serem altamente subjetivos e específicos para cada indivíduo, os 
Contratos Psicológicos podem referir-se a elementos concretos (pagamento, condições de trabalho) e abstratos (segurança, desafios) que são interpretados, no plano individual, pela relação que ocorre entre empregador e empregado. (GUZZO e NOONAN, 1994, p. 448). Isto posto, faz sentido criar uma tipologia representativa de modo a possibilitar o levantamento do conteúdo do Contrato Psicológico.

A classificação nominal tem sido amplamente utilizada em pesquisas sobre Contratos Psicológicos (Rousseau, 1990; Rousseau e McLean Parks, 1993; Millward e Hopkin's, 1998; Rousseau, 2000; Hui, Lee e Rousseau, 2004; Raja, Johns e Ntalianis, 2004 entre outros). Proposta inicialmente por Macneil (1985), muitos acadêmicos desenvolveram e adotaram uma tipologia baseada nos contratos promissórios, representada pelos contratos transacionais e relacionais.

Os Contratos Psicológicos transacionais referem-se àqueles que são extraídos de termos de troca bem descritos. Usualmente, os termos de troca são monetarizados, específicos e de restrição limitada. Conforme define Rousseau (2000), “employment arrangements with a short-term on limited duration, primarily focused upon economic exchange; specific, narrow duties and limited worker involvement in organization." 40 (ROUSSEAU, 2000, p.4). Portanto, tendem a ser mais explícitos. Os Contratos Psicológicos relacionais são menos definidos com base nos termos de troca. Normalmente são abstratos, não monetarizáveis, referem-se a aspectos amplos da relação do empregado com o empregador e tendem a ser mais implícitos. Para Rousseau, "long-term and open-ended employment arrengements based upon mutual trust and loyalty. Reward are only loosely conditioned on performance, derive from membership and participation in the organization." 41 (ROUSSEAU, 2000, p.4).

Para Rousseau (1995), os termos dos Contratos Psicológicos podem ser pensados como extremos de um continuum, como mostra a figura 2 desenvolvida pela própria autora.

\footnotetext{
${ }^{40}$ Emprego com um regime de curto prazo com duração limitada, essencialmente centrado no intercâmbio econômico; deveres específicos e restritos, e envolvimento limitado do trabalhador na organização.

${ }^{41}$ Emprego com regime de longo-prazo com duração ilimitada, centrado em confiança e lealdade mútuas. Recompensas estão vagamente condicionadas ao desempenho, derivam de adesão e participação na organização.
} 
Econômico Foco Econômico, Emocional

Parcial Inclusão Pessoa Inteira

Especifica Perspectiva de tempo Indefinida

Escrito Formalização Escrita e não escrita

Estático Estabilidade Dinâmico

Estreito Escopo Amplo

Público, Observável Tangibilidade Subjetivo, Implícito

Figura 2: O continuum dos termos do contrato Fonte: Rousseau, 1995, p. 92, tradução nossa.

Este continuum pode ser representado pelos termos do Contrato Psicológico transacional e relacional, conforme seguem.

Os termos do Contrato Psicológico transacional incluem:

- condições econômicas específicas como incentivos primários (salário, bônus, plano de saúde, previdência privada e assim por diante);

- envolvimento pessoal limitado no trabalho (trabalhar poucas horas, pouco investimento emocional);

- $\quad$ perspectiva de tempo específica, limitada (emprego temporário, duração no trabalho por tempo limitado);

- $\quad$ comprometimento limitado às condições específicas (contrato sindical);

- $\quad$ pouca flexibilidade (mudanças no trabalho requerem negociação do contrato);

- $\quad$ uso de habilidades existentes (sem desenvolvimento das mesmas) e

- $\quad$ inexistência de ambigüidade dos termos entendidos entre as partes. (ROUSSEAU, 1995, p. 91, tradução nossa).

Os termos do Contrato Psicológico relacional incluem: 
- $\quad$ envolvimento emocional tão quanto trocas econômicas (suporte pessoal, preocupação com o bem-estar da família);

- $\quad$ relações pessoais completas (crescimento e desenvolvimento);

- $\quad$ perspectiva de tempo indefinida (indefinidamente);

- $\quad$ termos escritos e não escritos (alguns termos emergem com o tempo);

- $\quad$ relações amplas (afetos pessoais e vida familiar) e

- $\quad$ entendimento subjetivo e implícito (condições difíceis para uma terceira parte entender). (ROUSSEAU, 1995, p. 92, tradução nossa).

Compreendidos quais conteúdos do Contrato Psicológico são trabalhados nas pesquisas e de que forma são operacionalizados, é de fundamental importância discutir o foco das pesquisas acadêmicas no mundo. A partir disto, será possível compreender melhor o atendimento dos objetivos desta tese, bem como suas escolhas metodológicas.

\subsection{As pesquisas em Contratos Psicológicos}

Atualmente, o tema mais trabalhado nas pesquisas sobre Contrato Psicológico no mundo é a ruptura e a grande massa produzida está nos E.U.A. Provavelmente, o grande interesse em torno do assunto ocorre porque esta é a forma de entender como os Contratos Psicológicos afetam os sentimentos, as atitudes e comportamentos dos indivíduos no ambiente de trabalho.

Para Rousseau e Parks (1993), ruptura do Contrato Psicológico ocorre quando o empregado percebe que a organização falha no preenchimento das obrigações do Contrato Psicológico. Como sugere a definição, o oposto de ruptura é o preenchimento, atendimento do contrato.

Pesquisadores utilizaram as palavras ruptura e violação como sinônimos até quando Morrinson e Robinson (1997) distinguiram formalmente os conceitos, distinção esta aceita atualmente. As autoras descrevem ruptura como uma comparação cognitiva entre o que foi recebido pelo indivíduo e o que foi prometido pela empresa, ou seja, a percepção de uma discrepância entre o que foi prometido e o que de fato o indivíduo recebeu. Violação, por 
outro lado, foi descrita como uma reação emocional ou afetiva intensa que pode acompanhar a ruptura. O diagrama 1, a seguir, explica o processo da violação dos Contratos Psicológicos.

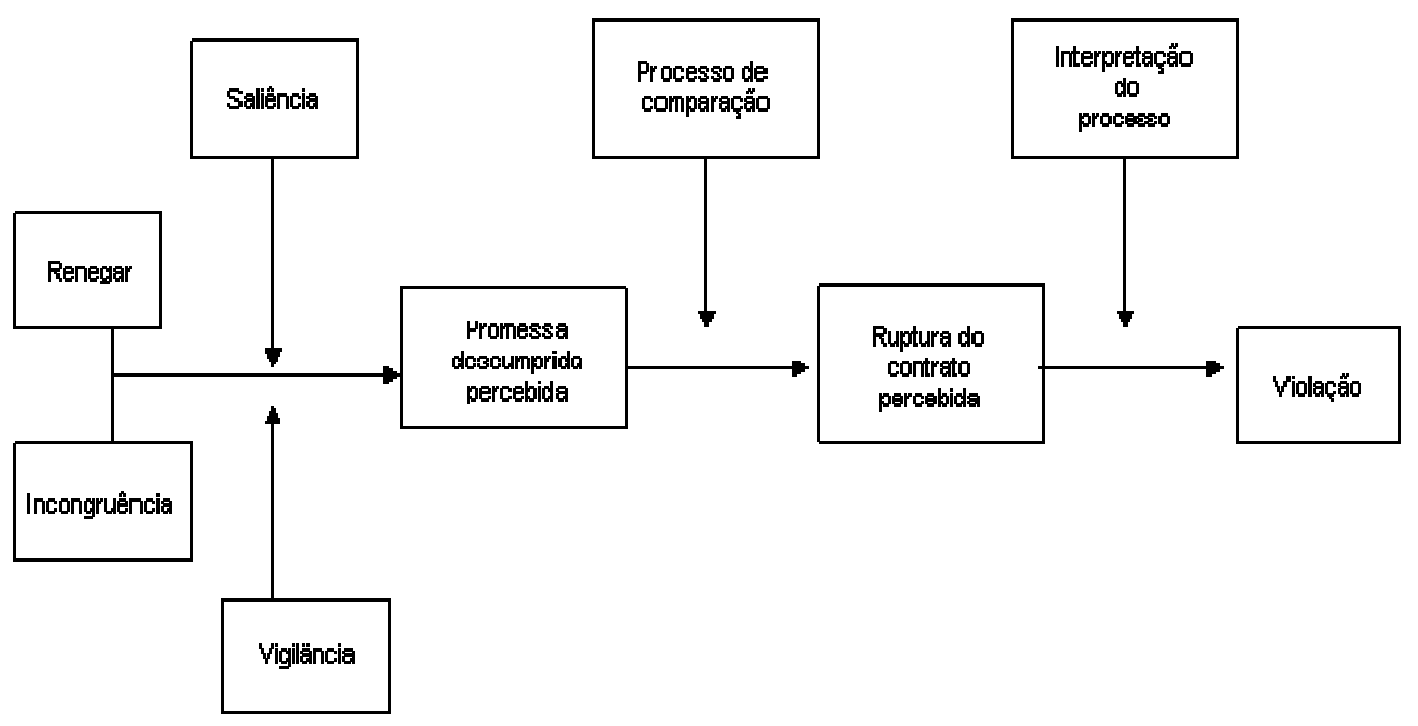

Diagrama 1: Processo da violação do Contrato Psicológico Fonte: adaptado de Robinson e Morrinson, 1997, tradução nossa.

De acordo com o diagrama 1 apresentado, a percepção de ruptura do contrato pode ser causada por duas condições: renegar e incongruência. A primeira ocorre quando a organização reconhece uma obrigação, mas não a preenche, ou porque não está capacitada para tal (razões relacionadas a problemas externos ou internos da organização, por exemplo), ou porque não está disposta (razões relacionadas à conduta do funcionário, por exemplo). A segunda ocorre quando organização e empregado não possuem a mesma compreensão dos termos do contrato. Estas duas condições podem causar uma percepção de que a promessa não fora preenchida. Mas tal percepção será influenciada por dois outros fatores: 1) saliência, que se refere ao grau em que um estímulo aparece em um contexto imediato. A saliência será afetada por fatores como o tamanho da discrepância, a importância da promessa, quão viva a promessa está na cabeça do empregado; 2) vigilância, que se refere à extensão em que o empregado monitora o quanto a organização preenche os termos do Contrato Psicológico. 
A percepção de que uma promessa não foi preenchida pode gerar um processo de comparação pelo qual o empregado avalia o quanto cada uma das partes da relação de trabalho compareceu com suas obrigações. Se concluir que os resultados são desfavoráveis para si, ele perceberá, então, uma ruptura do contrato. "Essa comparação está sujeita ao viés cognitivo e à determinação do limiar da ruptura." (PEYRAT-GUILLARD, 2008, p. 483, tradução nossa). Ao perceber a ruptura, o empregado estará sujeito a interpretar este processo, que consiste na tentativa de dar sentido ao evento ocorrido.

Because people are especially likely to seek out sense-making information in response to events that are unexpected or negative (Wong and Weiner, 1981), we predict that the perception of a contract breach will serve as a trigger for this cognitive sense-making process. Nonetheless, an employee will in some cases make sense of a breach subconsciously, such that feelings of violation may be elicited without an employee's conscious awareness of the preceding judgments (Lazarus, 1982). In other words, an employee may feel intense anger or even outrage in response to a perceived breach but be unable to articulate the cognitive appraisals that underlie those emotions. ${ }^{42}$ (MORRINSON e ROBINSON, 1997, p. 242).

Dependendo do processo de interpretação do indivíduo, este poderá insurgir na reação violação do Contrato Psicológico.

Acredita-se que pelo fato da ruptura dos contratos psicológico promover conseqüências importantes para a organização, pesquisadores concentraram seus esforços na investigação de como a ruptura afetaria os resultados do indivíduo perante a organização, ou seja, as conseqüências desta.

Diversos estudos (Robinson, 1996; Robinson, Kraatz e Rousseau, (1994); Robinson e Rousseau (1994); Robinson e Morrinson (1995); Turnley e Feldman (1999, 2000); Lester et al.(2002); Coyle-Shapiro and Kessler (2002); Kickul, Lester e Fink (2002)) concluíram que a ruptura está relacionada a níveis mais baixos de bem-estar do indivíduo no trabalho; atitudes negativas perante o trabalho e a organização, como insatisfação no trabalho, baixo comprometimento organizacional, diminuição dos níveis de confiança e aumento da intenção

\footnotetext{
${ }^{42}$ Porque as pessoas são particularmente suscetíveis de procurar sentido na tomada de informação em resposta a eventos que são inesperados ou negativos (Wong e Weiner, 1981), prevê-se que a percepção de ruptura de um contrato servira como um gatilho para esse processo cognitivo. No entanto, um trabalhador, em alguns casos, pode perceber a existência de uma ruptura subconscientemente, de tal forma que sentimentos de violação podem surgir sem a consciência dos julgamentos anteriores (Lazarus, 1982). Em outras palavras, um empregado pode sentir raiva intensa ou mesmo indignação em resposta a uma violação percebida, mas ser incapaz de articular as avaliações cognitivas que subjazem essas emoções.
} 
de sair da organização; e comportamentos como baixo nível de cidadania organizacional, aumento da rotatividade voluntária, baixa performance. Uma análise, realizada por Conway e Briner (2005), dos resultados produzidos pelas pesquisas anteriormente citadas, somadas à de outros autores (ver tabelas do anexo I), mostram que a ruptura do Contrato Psicológico está negativamente relacionada à satisfação no trabalho (correlação média $=-0,46$ ) e ao comprometimento no trabalho (correlação média $=-0,32$ ) e positivamente relacionada à intenção de parar (correlação média $=0,33$ ). Da mesma forma, a ruptura está negativamente relacionada à comportamentos de cidadania organizacional (correlação média $=-0,20$ ), performance no trabalho (correlação média $=-0,19$ ) e positivamente relacionada à rotatividade (correlação média $=0,11$ ). Ao observarem os números médios produzidos, fica clara a maior relação entre a variável ruptura e o primeiro bloco de conseqüências do que a relação desta variável e o segundo bloco de conseqüências. Estes resultados fornecem insumos importantes sobre como as organizações deveriam tratar o gerenciamento dos Contratos Psicológicos havendo vontade das mesmas de controlar tais conseqüências no ambiente organizacional.

Desde a distinção feita entre ruptura e violação por Morrinson e Robinson (1997), muito se produziu sobre as conseqüências da ruptura, conforme apresentado anteriormente. Entretanto, como pontuam Conway e Briner (2005), "é notável que interesses em pesquisas sobre violação não se desenvolveram.” (CONWAY e BRINER, 2005, p. 65). O motivo mais provável deste desinteresse talvez esteja na facilidade de 1) estudar variáveis extensamente trabalhadas e consolidadas na literatura de comportamento organizacional, como é o caso das conseqüências da ruptura do Contrato Psicológico; 2) acessar tais variáveis nos indivíduos frente às diversas medidas delas disponíveis na literatura acadêmica; e na dificuldade de trabalhar a violação, já que 3) as reações à ruptura podem ser constrangedoras para o indivíduo, dificultando sua externalização, afinal podem trazer à tona suas fragilidades; 4) pode haver desinteresse por parte das organizações em conhecer e cuidar destes aspectos, que podem ser bastante sentimentais.

O estudo brasileiro realizado por Menegon (2004) apresentou algumas reações à ruptura que se caracterizaram como violação do Contrato Psicológico. Elas são expressas pelos termos: vingança, mágoa, depressão e alivio. Quatro anos mais tarde, Peyrat-Guillard (2008) realizou, na empresa francesa Michelin, um estudo que permitiu o levantamento de palavras que descrevessem as reações emocionais intensas, representando a violação. São elas: preocupação, raiva, ódio, amargura, ansiedade, revolta, traição e confusão. Observa-se 
que os estudos de Menegon e Peurat-Guillard convergem. Isto indica que, apesar dos estudos não estarem amplamente avançados neste exato assunto, os poucos produzidos estão alinhados. Para esta tese serão considerados os termos vingança, mágoa, depressão, amargura, ansiedade, revolta, traição e raiva/ódio (como sinônimos, porque conceitualmente fica difícil distinguir um sentimento do outro) para a consecução de um dos seus objetivos. Os demais termos não serão considerados porque apresentaram menor freqüência nas pesquisas, mostrando-se menos relevantes.

A seguir serão apresentadas as bases teóricas de Carl Gustav Jung, conhecimento importante para o entendimento global desta tese.

\subsection{A Psicologia Analítica de Carl Gustav Jung}

Como a Psicologia Analítica de Jung, além de ser considerada complexa por alguns teóricos, é extensa, neste trabalho serão abordados apenas os temas relevantes para o entendimento geral da teoria jungiana, para, em seguida, aprofundar os conceitos em torno da caracterologia deste mesmo autor. Isto posto, serão trabalhados os conceitos norteadores que permitirão a compreensão do objetivo deste estudo, bem como suas hipóteses.

\subsubsection{A estrutura da Personalidade}

A personalidade, denominada por Jung psique, é formada por sistemas diferenciados, mas que interagem. "A psique abrange todos os pensamentos, sentimentos e comportamentos conscientes e inconscientes." (CASADO, 1998, p. 25) do ser humano, e sua denominação permite entender que, para a Psicologia Analítica, o indivíduo nasce inteiro, diferentemente de outras correntes da psicologia que afirmam que o homem vai adquirindo personalidade à medida em que cresce e se desenvolve, até surgir uma unidade deste.

Os sistemas que compõem a psique e interagem são o ego, o inconsciente pessoal e seus complexos, o inconsciente coletivo e seus arquétipos persona, anima e o animus, a sombra e o self. Somados a esses sistemas interdependentes, existem os tipos gerais de atitudes, introversão e extroversão, e as funções psíquicas: pensamento, sentimento, sensação e intuição. Todos esses conceitos serão explicitados a seguir. 
A personalidade é composta pela consciência, o inconsciente individual e o coletivo.

A consciência é representada pelo ego, que é a mente consciente, constituindo percepções, memórias, pensamentos e sentimentos conscientes que nos fornecem o senso de identidade e continuidade.

O inconsciente pessoal consiste nas experiências que um dia foram conscientes, mas que por algum motivo foram suprimidas, reprimidas, ignoradas ou mesmo esquecidas, e que estão acessíveis à consciência do indivíduo. O complexo é formado pelos sentimentos, pensamentos, percepções e memórias que foram depositados no inconsciente do indivíduo.

O inconsciente coletivo, considerado o mais poderoso e influente da psique, é o sistema em que estão depositados traços de memória latentes herdados do nosso passado ancestral. "É o resíduo psíquico do desenvolvimento evolutivo humano, um resíduo que se acumula em conseqüência de repetidas experiências ao longo de muitas gerações.” (HALL, LINDZEY e CAMPBELL, 2000, p.88).

Os arquétipos, que também podem ser denominados padrões de comportamento (JUNG, 1991), são componentes estruturais do inconsciente coletivo. São formas de pensar coletivas. É como se indivíduos herdassem uma predisposição para enxergar o mundo ou perceber as coisas. "É um depósito mental permanente de uma experiência que foi repetida constantemente por muitas gerações.” (HALL, LINDZEY e CAMPBELL, 2000, p.90). Jung (1991) acredita existirem muitos arquétipos no inconsciente coletivo, como: nascimento, renascimento, morte, poder, mágica, unidade, o herói, a criança, o Deus, o demônio, o velho sábio, a mãe terra e o animal.

Apesar dos arquétipos serem considerados sistemas dinâmicos autônomos, independentes do restante da personalidade, "alguns arquétipos evoluíram tanto que merecem ser tratados como sistemas separados dentro da personalidade. Eles são a persona, a anima e o animus, a sombra” (HALL, LINDZEY e CAMPBELL, 2000, p.90) e o self.

A persona é a mascara ou atitude assumida pelas pessoas em resposta às diferentes "exigências e opiniões do meio ambiente, prevalecendo ora um ora outro momento." (JUNG, 1991 p. 389). É a função psíquica voltada para o mundo externo em busca de adaptação às suas exigências. Para este autor, a dissociação da personalidade não somente é possível em uma pessoa normal, como deve existir, tendo em vista as necessidades impostas pelo meio em que os indivíduos vivem. Cada meio exige diferentes atitudes, que por sua vez requerem papéis diferenciados. (JUNG, 1991). 
Embora a persona tenha o propósito de causar impressões nos diferentes meios em que atua, Jung (1991) afirma ser difícil responder qual das diferentes personalidades é a verdadeira. Pelo fato do indivíduo não possuir qualquer caráter verdadeiro e individual, e sim coletivo, cotidianamente pessoas assumem máscaras em resposta às convenções sociais e expectativas em geral. Com isto, fica difícil dizer qual é verdadeiramente a personalidade pública ou privada.

De acordo com Hall, Lindzey e Campbell (2000):

(...) se o ego se identifica com a persona, como acontece freqüentemente, o indivíduo se torna mais consciente do papel que está desempenhando do que seus sentimentos genuínos. (...) Ele se aliena de si mesmo e toda a sua personalidade assume uma qualidade plana ou bidimensional. Ele se tona mera aparência de humano, um reflexo da sociedade ao invés de um ser humano autônomo. (HALL, LINDZEY e CAMPBELL, 2000, p.91).

"Assim como a experiência diária nos autoriza a falar de uma personalidade externa, também nos autoriza a aceitar a existência de uma personalidade interna." (JUNG, 1991, p.391). Assim sendo, Jung considera que a persona é a atitude externa, o caráter externo, enquanto a anima é a atitude interna. Para este autor, o caráter externo se comporta complementarmente ao interno. Ou seja, da mesma forma que existe uma personalidade individual que canaliza sua energia para o mundo externo, existe outra no mesmo indivíduo que canaliza a energia para o mundo interno - anima e animus - de forma a haver a compensação entre ambas, gerando um equilíbrio psíquico. Jung ilustra esta idéia quando cita o caso de pessoas que são externamente cruéis, duras e inacessíveis, mas internamente vulneráveis. Neste exemplo, é possível afirmar que a persona é representada pela dureza, crueldade externa, enquanto a vulnerabilidade representa a anima. Adicionando a idéia de complementaridade entre persona e anima, Jung atribuiu arquétipos ao lado feminino da personalidade do homem e ao lado masculino da personalidade da mulher. Ou seja, o arquétipo feminino no homem é chamado de anima, e o arquétipo masculino na mulher é chamado de animus. Para Jung, o fato do homem ter vivido ao lado de mulheres por muitos anos, fez com que o homem se feminilizasse e vice versa. Assim sendo, é absolutamente possível e esperado que homens manifestem características femininas e mulheres, masculinas. Como expressam Hall, Lindzey e Campbell (2000), “O homem apreende a natureza da mulher por meio de sua anima, e a mulher apreende a natureza do homem por meio de seu animus." (HALL, LINDZEY e CAMPBELL, 2000, p.91). 
$\mathrm{O}$ arquétipo sombra são os instintos animais herdados pelo homem durante sua evolução a partir de formas inferiores de vida (JUNG, 1948), ou seja, representa seu lado animal, a parte animalesca da personalidade. O arquétipo sombra é responsável pelo aparecimento de pensamentos e sentimentos conscientes desagradáveis, como aqueles considerados violentos, imorais e que são fortemente repreendidos pela sociedade e pelos próprios seres humanos. Entretanto, a sombra também possui seu lado positivo: ela é responsável pela capacidade criativa dos indivíduos, pela espontaneidade, pelas fortes emoções e insights dos seres humanos.

O arquétipo self ou o si-mesmo é o centro de toda a personalidade, é quem ordena os processos psíquicos inconscientes. Sua função consiste em ordenar, pela atração e harmonização, os demais arquétipos, oferecendo à personalidade o senso de unidade e equilíbrio à personalidade. O self é a meta que as pessoas buscam inconscientemente, mas que raramente alcançam. Por este motivo, por exemplo, muitas pessoas se apegam à religião. É como se buscassem se aproximar da imagem de figuras perfeitas e salvadoras como Cristo. Mas "antes que um self possa emergir, é necessário que vários componentes da personalidade se tornem totalmente desenvolvidos e específicos. Por essa razão, o arquétipo do self não se torna evidente até que a pessoa tenha atingido a meia idade. Nessa época, ela começa a fazer um sério esforço para mudar o centro da personalidade do ego consciente para um que esteja no meio do caminho entre a consciência e a inconsciência." (HALL, LINDZEY e CAMPBELL, 2000, p.92).

Os sistemas descritos anteriormente, juntamente com as atitudes e funções a serem apresentadas na seção subseqüente, compõem a personalidade. É importante frisar que esses componentes da personalidade, apesar de serem apresentados separadamente, não atuam desta forma. Pelo contrário. Os sistemas, de acordo com a proposição de Jung (1991), compensamse uns aos outros, opõem-se, ou ainda, unem-se, formando uma síntese. (CASADO, 1998). Neste sentido, torna-se importante o conhecimento do conceito de compensação que, segundo Jung, (1991) é a "equilibracão funcional, como auto-regulação do aparelho psíquico. (...) a atividade do inconsciente (v.) como equilibração da uniteralidade da atitude geral, causada pela função da consciência.” (JUNG, 1991, p. 399). De forma ilustrativa, pode-se dizer que a compensação ocorre quando há interação entre o ego (consciente, masculino) do homem com a anima (inconsciente, feminina) (CASADO, 1998), ou seja, um conteúdo da mente consciente é compensado pelo conteúdo da mente inconsciente. Esta interação fornece equilíbrio entre elementos contrastantes da psique. 
Conforme mencionado no início desta seção, além destes sistemas interdependentes, Jung apresentou em seu arcabouço teórico os conceitos de tipos gerais de atitudes e as funções psíquicas como forma de explicar a orientação e processos inerentes ao ego. Estes conceitos serão trabalhados na seção seguinte.

\subsubsection{A descrição geral dos tipos}

Para melhor compreensão desta seção, é importante explicitar quatro conceitos. Entende-se por objeto "tudo o que está fora do indivíduo e que o cerca: pessoas, coisas, costumes, convenções, instituições sociais, condições físicas. Sujeito se reporta ao mundo interior e privado da psique; um mundo não diretamente observável por quem está de fora." (CASADO, 1993, p.31). Por libido entende-se a energia psíquica, sendo que tal energia é considerada como a intensidade do processo psíquico. Em outras palavras, "é uma manifestação da energia vital. Da mesma forma que a energia vital, a energia psíquica origina-se dos processos metabólicos do organismo. Da mesma forma que o alimento é transformado em energia biológica, as experiências são 'consumidas' e transformadas em energia psíquica." (CASADO, 1993, p.17). Por sujeito entende-se o ser individual, diferente de tudo aquilo que não for ele mesmo.

Os tipos gerais de atitudes representam a direção do interesse ou comportamento de um indivíduo em relação ao objeto, pelo movimento de sua libido, e são caracterizados pela extroversão ou introversão. Em termos gerais, o indivíduo introvertido enfatiza a importância do sujeito, enquanto o extrovertido, o objeto.

Segundo Jung (1991), “O introvertido (...) está basicamente preocupado em retirar a libido do objeto como forma de se prevenir contra um superpoder do objeto. O extrovertido, ao contrário, comporta-se de modo positivo diante do objeto." (JUNG, 1991, p. 316). Em resumo, o sujeito extrovertido é aquele que se doa para o mundo que o cerca, enquanto o introvertido protege-se das solicitações externas, defendendo-se do dispêndio de energia para o objeto.

Isto posto, é possível perceber que os dois tipos são diversos e opostos. Para Jung (1991), essa oposição é natural, perceptível até para os leigos em psicologia. Trata-se de uma atitude inconsciente, ou seja, não é passível de escolha por parte do indivíduo, e é vista como uma ocorrência natural dos aspectos inconscientes e instintivos do homem. "Biologicamente 
falando, a relação entre sujeito e objeto é sempre uma relação de adaptação. (...) As atitudes típicas para com o objeto são, portanto, processos de adaptação.” (JUNG, 1991, p. 317).

A seção seguinte explicará em detalhes cada um dos tipos gerais apresentados. Conforme explicitado na seção 3.4.1, a personalidade dos indivíduos é composta pelos aspectos conscientes e inconscientes. Assim sendo, os tipos gerais de atitudes serão discutidos de acordo com a lógica da consciência e inconsciência.

\title{
3.6.2.1 O tipo extrovertido
}

\subsection{A atitude geral da consciência}

\begin{abstract}
se orienta pelos fatos que o mundo exterior fornece (...) predomina a orientação pelo objeto e pelo dado objetivo, de modo que as decisões e ações mais freqüentes e principais sejam condicionadas não por opiniões subjetivas, mas por circunstancias objetivas (...) vive de tal modo que o objeto, como fator determinante, desempenha em sua consciência papel bem maior do que sua opinião subjetiva. (...) sua consciência toda olha para fora porque a determinação importante e decisiva sempre lhe vem de fora. (JUNG, 1991, p. 319).
\end{abstract}

De acordo com as palavras de Jung (1991), o indivíduo extrovertido é o sujeito que vive, interessa-se pelos acontecimentos objetivos do ambiente próximo. Assim, pessoas, coisas, fatos despertam seu interesse, da mesma forma que seus atos são fortemente influenciados por estes. Assim sendo, as pessoas do tipo extrovertido focam suas atenções e interesses no mundo que as rodeia. Isso significa que a função mais importante na consciência do sujeito extrovertido é o objeto.

Mas o foco demasiado no objeto pode trazer ao extrovertido uma descompensação. Em uma primeira impressão, pode-se imaginar que o extrovertido é um sujeito muito adaptado à vida real, às circunstâncias dadas. Entretanto, este mesmo sujeito pode tender a ignorar ou levar em pouca consideração suas necessidades subjetivas, confundindo-se com tudo aquilo que o cerca, perdendo-se no objeto. $\mathrm{O}$ foco demasiado no objeto, ou perder-se no objeto, gera, no sujeito, perturbações que podem manifestar-se emocional ou fisicamente. Tais manifestações têm um significado de compensação entre sua natureza consciente e inconsciente. 
Desta forma, para um melhor entendimento da questão compensatória, faz-se necessária a apresentação da atitude geral da inconsciência do extrovertido.

\subsection{A atitude geral da inconsciência}

Para Jung, a relação do inconsciente com a consciência é compensatória. Neste sentido, Jung (1991) coloca:

A atitude do inconsciente, para uma efetiva complementação da atitude extrovertida consciente, apresenta uma espécie de caráter introvertidor. Concentra energia sobre o momento subjetivo, isto é, sobre todas aquelas necessidades e pretensões que são oprimidas ou reprimidas por uma atitude consciente demasiadamente extrovertida. (...) é facilmente compreensível que uma orientação pelo objeto e pelo dado objetivo violente uma série de manifestações, opiniões, desejos e necessidades subjetivos e roube aquela energia que lhes caberia naturalmente. (JUNG, 1991, 323).

Isto posto, é possível afirmar que a disposição geral de atitude extrovertida consciente equivale a uma disposição inconsciente introvertida. Em outras palavras, pelo fato do sujeito direcionar sua libido, seu comportamento e interesse no sentido do objeto, o movimento compensatório, necessário para a harmonia da psique, direciona a energia residual para aqueles aspectos que a extroversão do sujeito reprimiu.

Para Jung (1991),

o ajustamento e a assimilação ao dado objetivo impedem a conscientização de manifestações insuficientemente subjetivas. Essas tendências (idéias, desejos, afetos, necessidades, sentimentos etc.) assumem caráter regressivo, de acordo com o grau de sua repressão, isto é, quanto menos reconhecidas forem, tanto mais infantis e arcaicas se tornarão. (JUNG, 1991, p.323).

Deste modo, sujeitos que exacerbam suas tendências extrovertidas, reprimindo a expressão dos conteúdos inconscientes de modo a impedir a manifestação consciente dos sentimentos de natureza subjetiva, não destituem as emoções de energia. $\mathrm{Na}$ verdade, ao passarem para o inconsciente, adotam caráter infantil, primitivo, agressivo e arcaico, refletindo baixo grau de desenvolvimento e adequação. (CASADO, 1998). 
Isto demonstra que os aspectos inconscientes do extrovertido não se encontram inacessíveis ou quase. $\mathrm{O}$ que de fato ocorre é uma fluidez entre os aspectos conscientes e inconscientes do indivíduo, e muitas vezes fica difícil ao observador distinguir quais aspectos "de caráter atribuir à personalidade consciente e quais à personalidade inconsciente." (JUNG,1991, p. 326).

Explicitadas as atitudes gerais da consciência e inconsciência do tipo extrovertido, a seção seguinte discorrera sobre as do tipo introvertido.

\subsubsection{O tipo introvertido}

\subsection{A atitude geral da consciência}

Contrariamente ao que faz o tipo extrovertido, o introvertido orienta-se por fatores subjetivos. Entre a percepção do objeto e o agir do introvertido se interpõe uma opinião subjetiva impedindo que o agir assuma um caráter correspondente ao dado objetivo. A consciência introvertida vê as condições externas, mas escolhe as determinantes subjetivas como decisivas. Enquanto o extrovertido se apóia principalmente naquilo que provém do objeto, o introvertido se baseia em geral no que a impressão externa constela no sujeito. Isto se representa na forma de uma reserva do eu. (JUNG, 1991, p. 354).

“O introvertido observa as condições exteriores, mas são as determinações de caráter subjetivo as mais decisivas; seu foco não está no objeto, mas na impressão que o objeto causa nele, sujeito." (CASADO, 1998, p. 40).

Isto significa que o indivíduo introvertido é o sujeito que se interessa mais pelas impressões e conclusões elaboradas intimamente ao observar acontecimentos do ambiente próximo ou não. As tendências e concepções subjetivas são mais fortes que a influência do objeto; seu valor psíquico é maior, de modo que se sobrepõem a qualquer impressão. Assim sendo, as pessoas do tipo introvertido focam suas atenções e interesses nos aspectos subjetivos. Isso significa que a função mais importante na consciência do sujeito introvertido é o subjetivo.

Para um melhor entendimento da questão compensatória, faz-se necessária a apresentação da atitude geral da inconsciência do introvertido. 


\subsection{A atitude geral da inconsciência}

"A posição de superioridade do fator subjetivo na consciência significa valorização menor do fator objetivo.” (JUNG, 1991, p. 358). Na atitude do inconsciente surge a valorização do fator objetivo.

O indivíduo, ao dar ênfase a seus processos internos, relega o objeto a uma situação inferior que se torna insustentável: a resposta do inconsciente, por meio de mecanismos compensatórios, é o aumento da importância e força do objeto. (CASADO, 1998, p.41).

O inconsciente cuida, antes de tudo, da relação com o objeto de forma a destruir completamente a ilusão de poder e de fantasia de superioridade da consciência. (JUNG, 1991, p. 358).

As conseqüências sentidas pelo homem introvertido quando sua disposição inconsciente assume o comando são descritas da seguinte forma por Jung (1991):

Devido à deficiente relação do eu com o objeto (...) surge no inconsciente uma relação compensatória com o objeto que se manifesta como vinculação incondicional e irreprimível ao objeto. Por mais que o eu procure assenhorearse de todas as liberdades possíveis, e queira ser independente, superior e sem obrigações, torna-se escravo do dado objetivo. A liberdade do espírito fica presa às cadeias de uma vergonhosa dependência financeira, a despreocupação no agir se recolhe, vez por outra, por medo da opinião pública, a superioridade moral desanda para o lamaçal de relações menos recomendadas, o prazer de dominar acaba em desejo de ser amado. (JUNG, 1991, p.358).

Apresentados os tipos gerais de atitudes, a seguir serão apresentadas as funções psíquicas, que também compõem o conceito de personalidade desenvolvido por Jung.

\subsubsection{As funções psíquicas}

Além das disposições de atitude descritas anteriormente acerca das diferenças individuais, Jung introduziu, a partir de suas indagações sobre o processo de ajustamento do homem, dois pares de funções para explicar as diferenças cognitivas do indivíduo ao adquirir e processar informações. 
Ainda que fosse possível explicar a natureza do homem pela sua inclinação em relação ao objeto, Jung entendeu que as diferenças de tipo geral de atitude não eram suficientes para explicar como pessoas com a mesma disposição básica se revelavam diferentes em ações cotidianas ou mesmo naquelas "de maior importância para o ajustamento ao mundo." (CASADO, 1991, p.42). Jung percebeu, em bases puramente empíricas, que as diferenças apresentadas pelas pessoas de mesmo tipo geral de atitude possuíam certa homogeneidade e constância. Tal fato culminou na elaboração do conceito de Função Psíquica. “(...) de um modo bastante genérico, é possível distinguir os indivíduos não só por suas diferenças universais de extroversão e introversão, mas também de acordo as suas distintas funções psicológicas fundamentais.” (JUNG, 1967, p. 31).

Segundo Jung (1991),

Por função psicológica [ou psíquica] entendo uma certa forma psíquica de atividade que, em principio, permanece idêntica sob condições diversas. [...] Distingo ao todo quatro funções básicas: duas racionais e duas irracionais, respectivamente, o pensamento e o sentimento, a sensação e a intuição. Não posso indicar um motivo a priori porque considero estas quatro como funções básicas. Só posso dizer que foi fruto de longos anos de experiência. (JUNG, 1991, p. 412).

As funções psicológicas, ou psíquicas, orientam o indivíduo nas suas interações com o mundo e nos seus processos internos. Desta forma, as ações humanas seguem dois caminhos claros:

um que objetiva captar informações sobre as situações e o outro que se volta à decisão necessária para a ação. (...) [As funções psíquicas fornecem] ao homem as condições de se situar no mundo. (...) [Ela] é uma atribuição congênita que se reflete em habilidades, aptidões e tendências do comportamento do indivíduo em seu processo de ajustamento. Ao se imaginar ou refletir sobre as ações humanas, verifica-se que todas elas contam com dois momentos bem definidos: um que objetiva captar informações sobre as situações e outro que se volta à decisão necessária para a ação. As funções psíquicas guiam esses dois momentos, fornecendo as condições ao homem para se situar no mundo. (CASADO, 1998, p. 42)

À função psíquica voltada às informações, ou seja, que representam o momento da percepção do homem, Jung deu o nome de Função Perceptiva, ou ainda, Irracional. À função 
que representa o processo de julgamento daquilo que é apreendido, ou seja, voltada ao processo decisório do homem, Jung denominou de Função Judicativa, ou Função Racional.

As funções psíquicas descritas por Jung totalizam quatro e, como em toda a sua obra, apresentam opostos. Estas serão detalhadas na seção que segue.

\subsubsection{Funções Irracionais ou Perceptivas}

Para Jung, os indivíduos estão munidos de duas formas de perceber, ou ainda, de captar informações, apreender as coisas, os fatos, sem qualquer tipo de reflexão. Uma forma é o processo de sensação, outra é a intuição.

A sensação é determinada pelo objeto. É o processo pelo qual indivíduos tomam conhecimento das coisas por meio dos cinco sentidos. Por isso, é chamada de função da realidade, pois se atêm aos fatos concretos, detalhes da realidade que são trazidos pelos cinco sentidos. "as pessoas que preferem sentir (sensação), estão tão interessadas na realidade ao seu redor que dão pouca atenção a idéias que vêm vagamente de lugar nenhum." (MYERS e MYERS, 1997, p. 22). “Através da sensação, o indivíduo apreende a realidade de uma situação, focaliza o momento presente (o único real para ele) e capta os detalhes concretos numa ordem que é serial e seqüencial. A sensação provê informações plenas das medidas quantificáveis que vão posicionar o homem nas suas ações.” (CASADO, 1998, p. 43).

A intuição, função oposta à sensação, "transmite a percepção por via inconsciente. (...) qualquer conteúdo se apresenta como um todo acabado sem que saibamos explicar ou descobrir como esse conteúdo chegou a existir.” (JUNG, 1991, p. 430). Ela permite perceber além dos cinco sentidos, como se fosse o sexto sentido, pois ocorre por meio do inconsciente. Tais contribuições inconscientes são normalmente expressas pela 'intuição feminina', os chamados 'palpites' ou ainda as premonições. A captação das informações ocorre, diferentemente dos indivíduos sensação, de forma caótica, não serial. 


\subsubsection{Funções Racionais ou Judicativas}

Para Jung, os indivíduos estão munidos de dois processos cognitivos que os apóiam no processo de tomada de decisão ou, ainda, de organizar e estruturar as informações para tomar suas decisões no caminho para seu ajustamento. São eles: o pensamento e o sentimento.

A função pensamento se orienta pelos dados objetivos e pelo objeto. “(...) é aquela função psicológica que, de acordo com suas próprias leis, faz a conexão (conceitual) de conteúdos de representação a ele fornecidos." (JUNG, 1919, p. 434). "Ocorre quando o indivíduo conduz a sua vida sob o comando da reflexão, de modo que todas as ações mais importantes sejam fruto de motivações intelectualmente geradas, ou, ao menos, tenha esta tendência (...)”. (JUNG, 1919, p. 330). A função pensamento permite a análise fria e racional, intelectual dos conteúdos de representação fornecidos, desconsiderando as interferências de natureza emocional na tomada de decisão. Não que os processos emocionais inexistam no indivíduo, pelo contrário. A função pensamento apenas orienta o processo de tomada de decisão para critérios objetivos e racionais.

A função oposta complementar do pensamento é a função sentimento. Orientado por esta função, o indivíduo atribui ao conteúdo um valor definido. Isto significa dizer que ele organiza e estrutura as informações para tomar decisões de maneira pessoal e orientada para valores. “A ação da função Sentimento sempre redunda num juízo emocional, suas decisões têm sempre um caráter pessoal e sua interferência é sempre para considerar a reação das pessoas envolvidas nas decisões. (...) leva em conta (...) o que se quer fazer. É através desta função que o indivíduo consegue a conexão com as formas de sentir dos demais sobre as várias coisas do mundo." (CASADO, 1998, p. 44).

Embora as pessoas possuam as quatro funções psíquicas, estas não atuam igualmente nos indivíduos, pois Jung, empiricamente, verificou que as pessoas acabam usando uma delas para se orientar e ajustar ao mundo. "Habitualmente, uma das quatro funções é mais diferenciada do que as outras três e desempenha um papel dominante na consciência." (HALL, LINDZEY e CAMPBELL, 2000, p. 93). Esta função diferenciada denomina-se função superior, e a menos diferenciada das quatro funções é chamada de função inferior. Estas serão explicitadas na seção que segue. 


\subsubsection{A função superior e a inferior}

Conforme mencionado anteriormente, a partir de seus experimentos, Jung verificou que as pessoas, apesar de possuírem as quatro funções psíquicas, não as utilizam de forma homogênea.

$\mathrm{O}$ exame minucioso do caso individual mostra o fato claramente rotineiro que ao lado da função mais diferenciada existe sempre uma segunda função, de importância secundária, e, portanto, de menor diferenciação na consciência e relativamente determinante. (...) mas só falamos de conscientização de uma função quando não apenas seu exercício está à disposição da vontade, mas também seu principio é decisivo para a orientação da consciência. (JUNG, 1991, p. 381).

o que se sabe por experiência é que [o homem] acaba por usar preferencialmente uma [das quatro] funções para se orientar e se ajustar ao mundo. Esta função se torna cada vez mais e mais desenvolvida, diferenciada e dominante - torna-se a Função Superior. (CASADO, 1998, p. 45).

A Função Superior está presente no nível consciente do indivíduo. "Surge pelo exercício e desenvolvimento de traços congênitos e dá a cada indivíduo suas características psicológicas particulares." (CASADO, 1993, p.38). Sua função oposta - Função Inferior repousa no nível inconsciente.

Segundo a teoria Jungiana, que é regida pelas leis da compensação e complementação, para compensar a presença da Função Superior no nível consciente, a Função Inferior repousa no nível inconsciente.

Apesar da importância do processo dominante ou da Função Superior, um processo apenas não é suficiente. As pessoas, para atingirem seu equilíbrio, necessitam de um processo auxiliar, ou a Função Inferior.

Normalmente, a Função Inferior não é reconhecida pelos indivíduos, sequer utilizada. Quando emerge do inconsciente, apresenta-se de forma arcaica, primitiva e infantil, "conferindo ao comportamento uma natureza temperamental, passional, selvagem." (CASADO, 1998, p.45). Mas se as quatro funções forem capazes de emergir no nível da consciência, pode-se falar em um homem completo.

A função inferior é sempre da mesma natureza da Função Superior. Isto quer dizer que se a Função Superior é perceptiva, a Inferior será da mesma natureza, ou seja, perceptiva. 
Conforme exemplificam Myers e Myers (1997),

(...) os ENT que consideram a intuição mais interessante do que o pensamento darão obviamente maior trânsito a ela, subordinando-lhe o pensamento. A sua intuição adquire validade pessoal inquestionável, que nenhum outro processo poderá igualar. Eles desfrutarão, usarão e confiarão na intuição de forma completa. As suas vidas serão moldadas para dar máxima liberdade à conquista dos objetivos intuitivos. Por ser a intuição um processo perceptivo, os ENT agirão perante o mundo com uma atitude perceptiva. Eles consultarão seu julgamento somente quando isso não conflitar com a intuição. (...) Por outro lado, os ENT que consideram o pensamento mais atraente do que a intuição tenderão a deixá-lo tomar conta de suas vidas, pondo a intuição em segundo lugar. $\mathrm{O}$ pensamento ditará os objetivos e à intuição será permitido apenas recomendar formas sutis de atingi-los. Como o processo que preferem é de julgamento, os ENT lidarão com o mundo com uma atitude julgadora. (MYERS e MYERS, 1997, p. 32).

O quadro 1 a seguir, apresenta as possibilidades de processos dominantes para os tipos psicológicos de Jung:

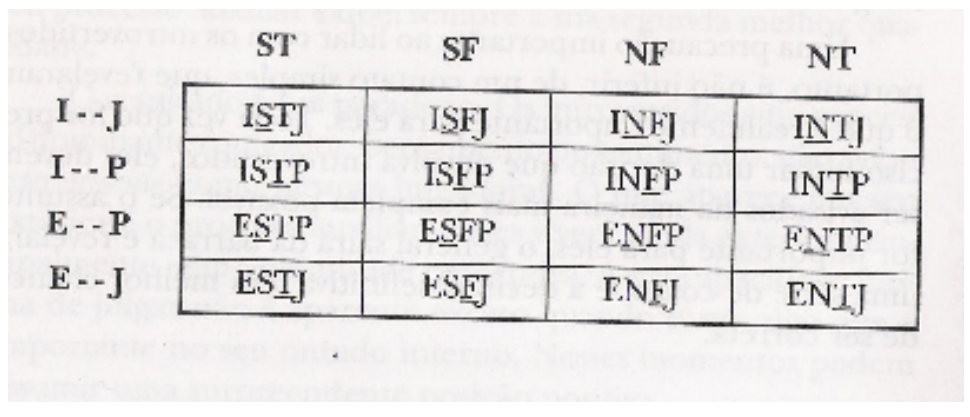

Quadro 1: Possibilidades de Função Superior Fonte: Myers e Myers, 1997, p. 38.

É possível perceber que, para cada um dos oito tipos psicológicos de Jung, é possível haver um processo dominante perceptivo ou judicativo. Tais processos podem ser identificados nas pessoas por meio dos testes psicológicos disponíveis, como o caso do DTP de Casado (1998).

As pessoas do tipo julgadoras entendem que a vida deva ser orientada e decidida. São pessoas que sempre chegam a conclusões. "Freqüentemente, os tipos julgadores estabelecem não apenas o que precisam estabelecer para si, mas também o que os outros precisam estabelecer.” (Myers e Myers, 1997, p. 97). Os tipos julgadores estabelecem sistemas de fazer as coisas, ou seja, decidem a melhor forma de fazê-las e depois as executam repetidamente. 
Preferem colocar ordem nos pertences, planejam a vida com programações e agendas; quando decididos, sustentam seus esforços para colocar suas decisões em prática; são pessoas altamente inclinadas para a decisão, não gostam de ver as coisas sem decisão; têm opinião formada e aceitam bem a rotina, até mesmo por estabelecerem-na para si mesmos. (Myers e Myers, 1997, pp. 97-100).

Os tipos perceptivos enxergam a vida como algo a ser experimentado e compreendido. São pessoas que "preferem manter planos e opiniões o mais abertamente possível para que nenhuma experiência valiosa ou nenhum esclarecimento possa perder-se." (Myers e Myers, 1997, p. 97). Os tipos perceptivos são espontâneos, sendo esta característica considerada uma habilidade de aceitar a experiência engrandecedora do momento presente. Estão sempre com aptos a admitir a consideração de novos fatos, idéias, propostas; compreendem bem o ponto de vista, buscando sempre novas possibilidades para as coisas e fatos. Caracterizam-se pela tolerância, pela curiosidade, pelo prazer da experiência e adaptabilidade. (Myers e Myers, 1997, pp. 97-100).

Apresentadas as Funções Superior e Inferior e os efeitos das preferências julgamento e percepção, seguem as explanações acerca dos mecanismos compensatórios nas funções psíquicas.

\subsubsection{Os mecanismos compensatórios nas funções psíquicas}

Conforme mencionado na seção 3.6.1, os componentes da personalidade compensamse uns aos outros, e são fortemente influenciados pela consciência e o inconsciente. Da mesma forma que a compensação ocorre com os sistemas da personalidade, também o faz em relação às funções psíquicas. Lembrando que o conceito de compensação, segundo Jung (1991), é a “equilibração funcional, como auto-regulação do aparelho psíquico. (...) a atividade do inconsciente (v.) como equilibração da uniteralidade da atitude geral, causada pela função da consciência.” (JUNG, 1991, p. 399), é possível afirmar que se uma função apresenta-se no nível consciente, a função oposta estará disponível no nível inconsciente. Aquelas funções que estiverem reprimidas no inconsciente, se ultrapassarem as barreiras impostas pela inconsciência e tornarem-se conscientes, apresentar-se-ão de forma inadequada, revelando o lado sombrio do indivíduo. Observe os mecanismos das funções psíquicas que seguem para entender as afirmações aqui colocadas. 


\subsection{Mecanismos compensatórios das Funções Perceptivas Sensação e Intuição}

Indivíduos com alta intensidade da Função Psíquica Sensação são pessoas com alta relação com o objeto, que se apegam somente àquilo que é real, concreto, e que possuem pouca inclinação para a reflexão, interiorização. São pessoas bastante sociáveis, gostam do contato direto com as pessoas. Mas se não houver um equilíbrio entre as funções perceptivas, todo o conteúdo inconsciente da intuição fará uma forte pressão no intuito de forçar sua entrada para o nível consciente. Sob esta perspectiva, o indivíduo pode tornar-se "vulgar ou sem respeito pelo objeto". (CASADO, 1998, p. 46) ou, ainda, ser "levado, através de sua função Intuição indiferenciada, a comportamentos bizarros de natureza 'mágica', bem como as camadas sombrias e ambíguas da realidade.” (CASADO, 1998, p. 46).

Em casos em que a função Intuição é intensa, o indivíduo abandona "situações nas quais os desafios tenham sido vencidos e as novas possibilidades tenham se esgotado; isto faz com que o indivíduo sacrifique todo o resto em busca de novas perspectivas." (CASADO, 1998, p. 46 - 47). São pessoas fortemente voltadas para a reflexão, muitas vezes introspectivas. Quando o conteúdo inconsciente da sensação pressiona sua saída para o nível consciente, forçando o indivíduo para as questões do objeto, o faz de maneira arcaica, infantil, levando-o à relações obsessivas com o objeto.

\subsection{Mecanismos compensatórios das Funções Judicativas Pensamento e} Sentimento

Indivíduos com alta intensidade da Função Psíquica Pensamento atêm-se demais às regras impessoais, podendo apresentar traços de tirania, pois acreditam que suas regras, a sua forma de enxergar o mundo, que inclusive adota severamente para si, devam ser impressas para todos. Entendem que tais regras representam a justiça e a verdade universalmente válida.

Quando o conteúdo inconsciente pressiona com o intuito de entrar no nível consciente, perturba a ordem intelectual. Todos aqueles aspectos vitais da natureza humana - amizade, sentido artístico, paixões e assim por diante - reprimidos pela superioridade da função pensamento eclodem de modo arcaico, primitivo, tornando o indivíduo suscetível, frágil, com 
linguagem áspera e agressiva, seus sentimentos ganharão senso de urgência, e reações impróprias correm o risco de vir à tona. (CASADO, 1998, p. 47).

Em casos em que a função sentimento é intensa, o indivíduo vive em busca do belo, das emoções humanas.

O exagero faz com que o sentimento perca seu caráter pessoal, e se converta num 'sentir em si próprio', conferindo ao indivíduo ares pedantes, caprichosos e de teatralidade, perdendo por completo o calor humano original. (...) A função pensamento, inferiormente colocada, vem à tona sob a forma de observações negativas e desvalorizadas sobre aquelas mesmas coisas valorizadas pelo Sentimento, numa tentativa de anular o predomínio da função Sentimento. (CASADO, 1998, p. 47).

Explicitados os mecanismos compensatórios, faz-se necessário debruçar-se sob a interação entre os tipos gerais de atitudes com as funções psicológicas superiores.

3.6.4 A interação entre os tipos gerais de atitude e as funções psíquicas superiores

Tratados os tipos gerais de atitude e as funções psíquicas individualmente nas seções anteriores, cabe agora, explicitar as características das possíveis interações entre os mesmos, conforme aborda Jung em sua obra sobre os Tipos Psicológicos. A seguir serão apresentadas essas características.

\subsubsection{O tipo pensamento extrovertido}

Este tipo caracteriza-se pela forte subordinação das atividades de sua vida às suas conclusões intelectuais, pois estão sempre orientadas por dados objetivos. São pessoas que colocam ordem nas situações exteriores, de modo a ter sua mente absolutamente focada na situação objetiva. Sua capacidade reflexiva está alicerçada nas questões lógicas e objetivas. "Este tipo outorga não só a si mesmo, mas também aos circunstantes, a força decisiva da realidade objetiva, ou seja, de sua fórmula intelectual com orientação objetiva." (JUNG, 1991, p. 330). Tal fórmula, apresentada por Jung, é capaz de medir o bem e o mal, o belo e o feio. Tudo o que concorda com ela é certo, e o que a contradiz é errado, o tipo pensamento 
extrovertido se submeta às pessoas e ao mundo exterior. E faz isso porque quer o bem. Tudo o que está em desacordo com a fórmula é imperfeição e deve ser eliminado, por ser considerado doentio.

Sua conduta pauta-se em princípios e não em valores. Este tipo tem "uma espécie de ligação sentimental mística com os ideais e, freqüentemente, também com as pessoas." (FRANZ, 2005, p. 62).

O sentimento inconsciente dá a impressão de que são seres frios, desprovidos de afeto. Normalmente, quando o sentimento aflora, explode na figura de um fanatismo, ou mesmo, de expressões de afeto inoportunas e inadequadas.

\subsubsection{O tipo sentimento extrovertido}

Geralmente encontrado em mulheres, este tipo caracteriza-se pela forte necessidade do sentir corretamente, ou seja, nada perturbando o sentimento. Ao pensar, estas pessoas consideram suas emoções e as dos outros, porque para elas, é impossível pensar algo que não possam sentir. "Não se diz com isso que esta espécie de mulher não pense de maneira alguma; ao contrário, talvez pense muito e de forma esperta, mas seu pensar nunca é sui generis (original) e, sim, um acessório epimeteico de seu sentimento.” (JUNG, 1991, p. 340).

São pessoas ajustadas, bastante razoáveis, que se envolvem amavelmente com o mundo e conseguem sempre o que querem. São pessoas que tornam o ambiente agradável, feliz, e sempre trazem consigo frases amáveis que agradam muito as pessoas. Percebem o valor do que deve ser feito e fazem.

O pensamento inconsciente pode provocar perturbação no sentir ao eclodir no nível consciente, trazendo pensamentos infantis, primitivos sob a forma de julgamentos hipercríticos ou negativos a respeito das pessoas que o rodeiam.

\subsubsection{O tipo sensação extrovertido}

Dos tipos humanos, este é o mais realista de todos. As pessoas deste tipo sentem e relacionam-se com os objetos de forma prática, realista, concreta. Por isso, são pessoas 
extremamente atentas às coisas e pessoas que se encontram em um ambiente, assim como o cheiro, as imagens. Têm excelente memória fotográfica e são capazes de observar os menores detalhes das coisas e pessoas.

Motiva-se em apreender sensorialmente os objetos, ter sensações. Jung comenta que tais indivíduos são geralmente percebidos como desalmados, frios e calculistas.

“Este tipo - parece que se trata geralmente de homens - não acha que esteja 'sujeito' à sensação. Ridicularizara esta afirmação como totalmente descabida, pois, para ele, sensação e manifestação concreta da vida significam plenitude de vida real. Sua intenção se volta para o gozo concreto, como também sua moralidade.” (JUNG, 1991, p. 345).

A intuição inconsciente, neste tipo, aflora sob forma de "premonições suspeitas, melancolia, idéias de possibilidades ruins (...)." (FRANZ, 2005, p. 41). Ao aflorar, pode trazer, com certa freqüência, atitudes negativas e autodepreciativas.

\subsubsection{O tipo intuição extrovertido}

Caracteriza-se pela forte inclinação e busca de possibilidades, não pelos valores reais e aceitos em geral. "Tem faro aguçado para o embrionário e para o que promete futuro." (JUNG, 1991, p. 349). A função intuição aguça a imaginação de possibilidades. Mas pelo fato de sua intuição estar orientada para o objeto, para o mundo exterior, aplica sua inclinação por novas possibilidades para o concreto, ou seja, aquilo que vislumbra é realizado, colocado em prática. São pessoas muito criativas que geram inovações futuras, pois praticam de fato suas invenções. Interessam-se por ambientes em que algo novo esteja fermentando. Contudo, quando possuem domínio da situação por elas criada, sentem-se em uma prisão, desinteressando-se pela situação que se estabilizou. Da mesma forma que são capazes de apreender-se a novos objetos, novas idéias ou situações, abandonam-nas com muita facilidade.

"Seu desapego às situações estáveis e conhecidas faz com que não se detenha nas coisas, nem usufrua de seus esforços - acaba sempre de mãos vazias.” (CASADO, 1998, p. 50). 
O pensar e sentir são reprimidos e vivem na esfera inconsciente. Quando afloram, apresentam-se de forma arcaica e infantil, sob a forma de idéias hipocondríacas, compulsivas e sensações corporais absurdas.

\subsubsection{5 $\mathrm{O}$ tipo pensamento introvertido}

O tipo pensamento introvertido privilegia o pensamento. Não aquele voltado ao dado objetivo, mas sim o voltado para o subjetivo. "Pertence ao tipo pensativo introvertido alguém que diria que não se parte dos fatos, mas, primeiramente, se esclarecem as idéias”. (FRANZ, 2005, p. 65).

Este tipo aprofunda-se nas idéias, e não na sua amplificação. Tais idéias fundamentam-se no sujeito, e não no objeto. Por isso, este tipo procura entender o papel do sujeito dentro dos contextos em que se colocam.

São pessoas perseverantes em suas idéias, fechadas às opiniões alheias, teimosas e não influenciáveis. "Seu julgamento parece frio, inflexível, arbitrário e duro porque relaciona-se menos com o objeto do que com o sujeito. (...) Quando seu produto subjetivo the parece correto e verdadeiro, então deve ser correto e os outros têm que se curvar-se a esta verdade." (JUNG, 1991, p. 363).

"Sua função inferior (sentimento extrovertido) é vulnerável ao objeto, razão pela qual em situações de crise, o tipo pensamento introvertido corre o risco de ser tragado pelo objeto, explorado e prejudicado." (CASADO, 1998, p. 50).

\subsubsection{O tipo sentimento introvertido}

O tipo sentimento introvertido é muito difícil de ser entendido, pois não expressa seus valores exteriormente. São pessoas "na maior parte das vezes, quietas, pouco sociáveis, incompreensíveis, muitas vezes se escondem atrás de máscaras infantis ou banais, e muitas vezes também são de temperamento melancólicos.” (JUNG, 1991, p. 367). 
Quando se manifestam externamente, são discretas, calmas, sem a pretensão de impressionar, persuadir ou mudar o outro. Aos olhos dos outros, parecem ser frias e indiferentes. Mas os sentimentos e emoções, neste tipo, desenvolvem-se nas profundezas.

“(...) freqüentemente formam a base ética de um grupo: sem irritar os outros com a pregação de preceitos morais e éticos, (...) emanam secretamente uma influência positiva sobre aqueles que estão a sua volta (...).” (FRANZ, 2005, pp. 75-76).

\subsubsection{O tipo sensação introvertido}

Caracteriza-se pela intensa influência subjetiva da introversão estimulada pelo dado objetivo. São pessoas pouco compreendidas. "Não é possível (...) prever de fora o que vai e o que não vai causar impressão.” (JUNG, 1991. p. 373). Costumeiramente questionam a finalidade da existência e dos objetos, “já que tudo de essencial acontece sem o objeto (...).”(JUNG, 1991. p. 373).

Este tipo desvaloriza o objeto inconscientemente, dificultando sua relação com pessoas e coisas do mundo exterior. "A impressão vem do objeto para o sujeito; é como se uma pedra caísse em águas profundas - a impressão cai mais fundo, mais fundo, e afunda dentro dele.” (FRANZ, 2005, p. 47). São pessoas que dispõem de reação interna rápida ao objeto, mas tal reação exterioriza-se lentamente.

A intuição "manifesta-se de modo pernicioso, voltando-se ao lado sombrio, perigoso e imundo que estão subjacentes à realidade; esta dinâmica dá lugar a obsessões repulsivas em relação ao objeto." (CASADO, 1998, p. 51).

\subsubsection{O tipo intuição introvertido}

Caracteriza-se pela forte inclinação e busca de possibilidades, não pelos valores reais e aceitos, em geral da mesma forma que o intuitivo extrovertido. Capaz de prever o futuro, fazer conjeturas. Conhece os "processos que ocorrem no inconsciente coletivo, as mudanças arquetípicas, e os comunica à sociedade.” (FRANZ, 2005, p. 55). Sua capacidade visionária tende a ser entendida somente nas gerações futuras. 
Indiferente para com o objeto, este tipo está distante da realidade concreta, verdadeira, e, por isso, é normalmente encontrado entre os artistas. São muitas vezes vistas como pessoas sem objetivos, vagabundas, perdidas.

O intuitivo introvertido freqüentemente é tão inconsciente no que diz respeito a fatos externos que os seus relatos têm de ser tratados com o maior cuidado. Assim, embora não minta conscientemente, ele pode contar as mais espantosas mentiras porque não percebe o que está bem à sua frente. (FRANZ, 1991, p. $56)$.

Quando a sensação extrovertida atravessa a barreira do inconsciente, apresenta-se na forma de neurose compulsiva, "que apresenta como sintomas, às vezes, fenômenos hipocondríacos, às vezes hiper-sensibilidade dos órgãos sensoriais, às vezes as ligações compulsivas por certas pessoas ou objetos." (JUNG, 1991, p. 379).

A obra de Jung (1991) apresentou oito tipos psicológicos que foram descritos anteriormente. Entretanto, duas donas de casa, mãe e filha - Katharine Cook Briggs e Isabel Briggs Myers, estudiosas dos postulados de Jung, apresentaram duas outras funções julgamento e percepção - derivadas do próprio trabalho de Jung. Na verdade, no desenvolvimento de sua obra sobre os Tipos Psicológicos, Jung menciona diversas vezes os termos percepção e julgamento para descrever determinados tipos, mas em nenhum momento os caracteriza de fato como um tipo.

Myers e Briggs criaram um inventário que ficou denominado MBTI - Myers Briggs Type Indicator. Por meio deste, seria possível diagnosticar as diferenças individuais de acordo com a tipologia jungiana. Em 1942, mãe e filha concluíram a versão preliminar, que passou por diversos processos de refinamento, até que em meados da década de 50, o inventário passou a ser reconhecido em centros de pesquisa e aplicação nos Estados Unidos da América. (Thorne e Gough, 1991 citado por Casado, 1998, p. 60).

Atualmente, o MBTI tem sido fonte de inspiração para diversos estudiosos das diferenças individuais bem como para os práticos da administração, sendo este o inventário de personalidade mais aplicado no mundo. (CASADO, 1998, p. 61). O MBTI tornou-se tão importante, que mesmo aqueles que lançaram mão de seus próprios instrumentos reconhecem sua grandeza. "O teste $[\mathrm{MBTI}]$ foi tão usado que criou um interesse internacional pela idéia de tipos de pessoas e reavivou o interesse pela teoria dos tipos psicológicos de Jung." (Keirsey e Bates, 1978 citado por Casado, 1998, p. 61). 
No Brasil, foi elaborado o Diagnóstico de Tipos Psicológicos - DTP (CASADO, 1998), instrumento validado e amplamente aplicado nas organizações brasileiras, e que será utilizado nesta tese. 


\section{Procedimentos metodológicos}

Trabalhos publicados recentemente (Conway e Briner, 2005; Raja, Johns e Ntalianis, 2004; DelCampo, 2007) demonstram a importância das pesquisas sobre o tema Contratos Psicológicos, mas, ao mesmo tempo, alertam a comunidade acadêmica dizendo que muitas lacunas ainda não foram preenchidas pelas pesquisas. Nos últimos anos, pesquisadores têm focado extensivamente o tema ruptura dos Contratos Psicológicos e seus efeitos e, por este motivo, Conway e Briner, 2005; DelCampo, 2007 intimaram a comunidade acadêmica no sentido de desbravar novos horizontes de pesquisas dentro do tema Contratos Psicológicos. Apontaram, em suas pesquisas, inúmeras questões que ainda não foram respondidas, como, por exemplo, a falta de conhecimento sobre a influência que a personalidade exerce sobre a elaboração dos Contratos Psicológicos e seus desdobramentos. Como forma de preencher esta lacuna de conhecimento, definem-se como objetivos centrais desta pesquisa: : 1) examinar se os tipos psicológicos exercem influência na captura e entendimento dos Contratos Psicológicos; 2) examinar se existe associação entre tipo psicológico e tipo de Contrato Psicológico; 3 ) examinar se existe associação entre o tipo psicológico e o comportamento do indivíduo ao se deparar com o não cumprimento do Contrato Psicológico.

Com esses objetivos, define-se para esta pesquisa o método quantitativo e o tipo de pesquisa descritiva. (SELLTIZ, 1974).

Isto posto, serão apresentadas a seguir as hipóteses que nortearão o trabalho no sentido de chegar a uma resposta válida aos objetivos propostos.

\subsection{As hipóteses}

Como forma de organizar uma seqüência compreensível desta seção, as hipóteses serão criadas de acordo com os blocos de conhecimento trabalhados no referencial teórico. Assim sendo, discutir-se-ão, primeiramente, as possíveis relações entre os tipos gerais de atitude e a teoria de Contratos Psicológicos, e entre funções psíquicas e a teoria dos Contratos Psicológicos

Em seguida, serão levantadas as possíveis hipóteses que surgem da relação entre a interação dos tipos gerais de atitudes e as funções racionais e irracionais com os Contratos 
Psicológicos. Por último, serão levantadas hipóteses a partir das possíveis relações entre Função Superior e Inferior e a teoria dos Contratos Psicológicos.

\subsubsection{Os tipos gerais de atitude e o Contrato Psicológico}

Conforme mencionado na seção 3.6 .2 (p. 44), os tipos gerais de atitude referem-se à direção da libido: o extrovertido orienta-se para o objeto e o introvertido "impede a preponderância do objeto" (JUNG, 1976, 386), preferindo "manter um ponto de vista que se interpõe entre ele e o objeto.” (JUNG, 1976, p. 390).

Ao ser examinado o relacionamento entre indivíduo e organização, está-se examinando uma relação entre o sujeito (indivíduo) e a organização (objeto). Os conceitos de Contrato Psicológico apresentam diferentes tipos de contratos estabelecidos entre indivíduo e organização, conforme seção 3.4 da Fundamentação Teórica, em que são apresentadas as classificações do Contrato Psicológico como relacionais e transacionais (Figura 2, p. 35).

Com base nas teorias discutidas, enuncia-se a primeira hipótese desta pesquisa:

Hipótese geral 1: O tipo de Contrato Psicológico (relacional ou transacional) estabelecido está associado ao tipo geral de atitude do indivíduo.

As pessoas extrovertidas se orientam pelos fatos que o mundo exterior fornece, se orientam pelo objeto e dado objetivo. (JUNG, 1991). "Seu interesse e atenção acompanham acontecimentos objetivos [relativos ao objeto], sobretudo do mundo que cerca." (JUNG, 1976, p. 390).

As pessoas introvertidas se baseiam em geral no que a impressão externa imprime no sujeito. (JUNG, 1991). A introversão "cinge-se ao que a impressão exterior opera no sujeito." (JUNG, 1976, p. 435).

Considerando-se que os Contratos Psicológicos transacionais referem-se aos termos de troca bem descritos entre o sujeito (indivíduo) e a organização (objeto) e tendem a ser mais explícitos, e que o "interesse e a atenção [do extrovertido] acompanham acontecimentos objetivos, sobre tudo do mundo que o cerca" (JUNG, 1976, p. 390), e que se comporta 
positivamente em face ao objeto, é possível supor que os extrovertidos elaborem Contratos Psicológicos transacionais.

Considerando-se que, para Rousseau (1989), os Contratos Psicológicos relacionais podem ser caracterizados por explícitos e implícitos, e que o introvertido prefere manter um ponto de vista que se interpõe entre ele e o objeto dado (que neste caso seria a organização), é possível supor que os introvertidos tendam a elaborar Contratos Psicológicos relacionais. Isto posto, formulam-se duas hipóteses específicas:

Hipótese 1a: Pessoas extrovertidas tendem a formar Contratos Psicológicos transacionais.

Hipótese 1b: Pessoas introvertidas tendem a formar Contratos Psicológicos relacionais.

\subsubsection{As funções psíquicas e o Contrato Psicológico}

Conforme exposto na seção 3.6.3 da Fundamentação Teórica, as funções psíquicas preferenciais referem-se à orientação do homem nas suas interações com o meio ambiente e nos seus processos internos. São divididas em funções psíquicas racionais (ou judicativas, que são: pensamento e sentimento) e irracionais (ou perceptivas, que são: sensação e intuição). Os tipos de Contratos Psicológicos são resultados da orientação dada ao processo de percepção de promessa do sujeito (indivíduo) em relação à organização (objeto). Considerando-se os tipos de Contratos Psicológicos estabelecidos pelos indivíduos para com a organização (relacional ou transacional), pode-se inquirir se as orientações (pensamento/sentimento e sensação/intuição) associam-se com os tipos de Contratos Psicológicos. De acordo com esta fundamentação, é possível estabelecer a segunda hipótese geral deste trabalho.

Hipótese geral 2: O tipo de Contrato Psicológico (relacional ou transacional) estabelecido está associado à função psíquica preferencial do indivíduo. 
“Às funções psicológicas voltadas às informações Jung deu o nome de Funções Perceptivas, já que municiam o homem para perceber o mundo (...).” (CASADO, 1998, p.42). São elas a sensação e a intuição.

Os indivíduos sensação tomam conhecimento das coisas por meio dos cinco sentidos, enquanto os intuição, por meio do sexto sentido.

Assim sendo, é possível supor que indivíduos sensação tenham maior inclinação para formar seus Contratos Psicológicos a partir dos termos de troca bem descritos entre sujeito e organização. Por meio dos cinco sentidos, eles procuram perceber a organização e atêm-se àquilo que já está disponível. Já os indivíduos intuição vão além do que está disponível para os sentidos para elaborar os Contratos Psicológicos. "A intuição (...) permite perceber além do que é possível pelos cinco sentidos (...) é um tipo de percepção voltada às relações não explicitadas, aos significados, às possibilidades. (...) A intuição provê as informações com respeito às ligações entre os fatos apreendidos." (CASADO, 1988, p. 44). Assim sendo, os fatos concretos apreendidos da organização ganham significado, influenciados pela percepção do intuitivo. Considerando-se que, para Rousseau (1989), os Contratos Psicológicos relacionais referem-se a aspectos amplos, implícitos da relação entre sujeito e objeto, é possível supor que indivíduos intuição tenham maior inclinação para formar Contratos Psicológicos relacionais a partir das conexões estabelecidas daquilo que capturam do ambiente organizacional. Isto posto, podem ser formuladas duas hipóteses específicas.

Hipótese 2a: Pessoas do tipo sensação tendem a formar Contratos Psicológicos transacionais.

Hipótese 2b: Pessoas do tipo intuição tendem a formar Contratos Psicológicos relacionais.

“Às funções voltadas ao processo de decisão Jung deu o nome de Funções Perceptivas, por sua natureza de apreciação e julgamento das coisas." (CASADO, 1998, p.42-3). São eles o pensamento e o sentimento.

A função Pensamento contribui para a conexão lógica entre os fatos e informações percebidos. (...) enfatiza a abordagem intelectual e fria das coisas, desconsiderando todas as implicações e interferências de ordem 
emocional nas suas ações. (...) [Esta função] não exclui a existência dos processos emocionais no indivíduo; apenas orienta sua tomada de decisão para os critérios objetivamente colocados. (CASADO, 1988, p. 44).

A partir desta definição, e considerando-se que o Contrato Psicológico transacional refere-se aos termos de troca bem descritos da relação entre empregador e empregado, ou seja, considera a troca na relação estabelecida, supõe-se que indivíduos pensamento tenham maior inclinação para formar Contratos Psicológicos transacionais.

A função Sentimento faz a apreciação dos objetos e situações levando em conta os valores associados. A ação da função Sentimento sempre redunda num juízo de valor emocional, suas decisões têm sempre um caráter pessoal (...). (CASADO, 1988, p. 44).

Frente à definição exposta, e considerando-se que o Contrato Psicológico relacional refere-se aos termos de troca presentes na relação e no vínculo entre empregado e empregador, ou seja, relaciona-se aos aspectos afetivos da relação, supõe-se que indivíduos sentimento tenham maior inclinação para formar Contratos Psicológicos relacionais. Isto posto, tem-se:

Hipótese 2c: Pessoas do tipo pensamento tendem a formar Contratos Psicológicos transacionais.

Hipótese 2d: Pessoas do tipo sentimento tendem a formar Contratos Psicológicos relacionais.

\subsubsection{A Função Superior e a Violação dos Contratos Psicológicos}

A discussão, realizada na seção 3.5 da Fundamentação Teórica, apresenta dois conceitos relativos aos Contratos Psicológicos. O primeiro é o de ruptura do Contrato Psicológico, que é o resultado de uma comparação cognitiva da discrepância entre o que foi prometido e o que de fato o empregado recebeu. Ao perceber a ruptura, o empregado estará sujeito a interpretar este processo, que consiste na tentativa de dar sentido ao evento ocorrido. As pessoas com Funções Superiores do tipo perceptivas (seção 3.6.3.3 da Fundamentação 
Teórica) são aquelas que inclinam-se ao encontro de novas possibilidades, contornam situações, procuram compreender as coisas e os fatos, muito mais do que julgá-los. Essas características aproximam-se do conceito de ruptura, em que o indivíduo procura dar sentido ao evento ocorrido. Assim sendo, pode-se supor que pessoas com Função Superior Perceptiva tenham maior inclinação a apresentar ruptura do Contrato Psicológico. Isto posto, tem-se:

Hipótese 3: Pessoas com Função Superior Perceptiva (sensação ou intuição) tendem a apresentar ruptura do Contrato Psicológico.

Dependendo do processo de interpretação do indivíduo em relação à ruptura, este poderá insurgir na reação violação do Contrato Psicológico, caracterizada por uma reação emocional ou afetiva intensa, que é o segundo conceito relativo aos Contratos Psicológicos mencionado no início desta seção. Pessoas com Funções Superiores Judicativas entendem que a vida deva ser orientada e decidida. São pessoas que sempre chegam a conclusões; quando decididas, sustentam seus esforços para colocar suas decisões em prática; são pessoas altamente inclinadas para a decisão e ação. Pelo fato do conceito de violação do Contrato Psicológico estar associado à noção de ação/reação, pode-se supor que as pessoas com Função Superior Julgadora tenham maior inclinação a apresentar violação do Contrato Psicológico. Isto posto, tem-se:

Hipótese 4: Pessoas com Função Superior Julgadora tendem a apresentar violação do Contrato Psicológico.

Apresentadas as hipóteses, a seção a seguir discutirá aspectos relacionados à população-alvo.

\subsection{População-Alvo}

A população-alvo escolhida para este trabalho foram os alunos de pós-graduação da Fundação Instituto Administração de São Paulo (FIA). A amostra compreendeu alunos e exalunos que foram submetidos ao Diagnóstico de Tipos Psicológicos - DTP (os detalhes sobre 
este instrumento serão apresentados na seção seguinte) entre o ano de 2008 e o primeiro semestre de 2009, totalizando 528 alunos e ex-alunos. Portanto, consideram-se conhecidos os tipos psicológicos dos participantes.

A FIA é uma entidade sem fins lucrativos que se estabeleceu em 1980, por uma iniciativa conjunta dos professores da Faculdade de Administração, Economia e Contabilidade da Universidade de São Paulo - FEA/USP. Atua em três linhas: pesquisa, consultoria e educação. Desde sua fundação, foram atendidas mais de 850 empresas, sendo que $48 \%$ da iniciativa privada nacional e multinacional, $40 \%$ do setor público e organizações da administração pública direta, e $12 \%$ são associações de classe e entidades da sociedade civil. Já formou mais de 6 mil alunos. Realizou inúmeros projetos de cunho ou impacto social em diversas áreas como educação, saúde, segurança pública, meio-ambiente, trabalho e emprego, terceiro setor, entre outras, em todo o país. (FIA, 2009). "Ao viabilizar a transferência do conhecimento gerado por seu corpo de colaboradores, a Fundação Instituto de Administração estabelece uma aproximação e maior integração do ambiente acadêmico com a sociedade brasileira." (FIA, 2009).

É reconhecida pelo MEC - Ministério da Educação e tem sua qualidade certificada pela Association of MBA's, sediada em Londres. Foi eleita a melhor escola de negócios do Brasil nos anos de 2005 a 2007 pelo Ranking Revista VOCÊ S.A. (FIA, 2009). No ano de 2008, os alunos da FIA apresentaram um tempo médio de experiência profissional de 11 anos e 7 meses, e tempo médio de carreira executiva de 5 anos e 2 meses. A idade média dos alunos formados em 2008 é de 33 anos. As áreas de atuação destes alunos compreendem: 


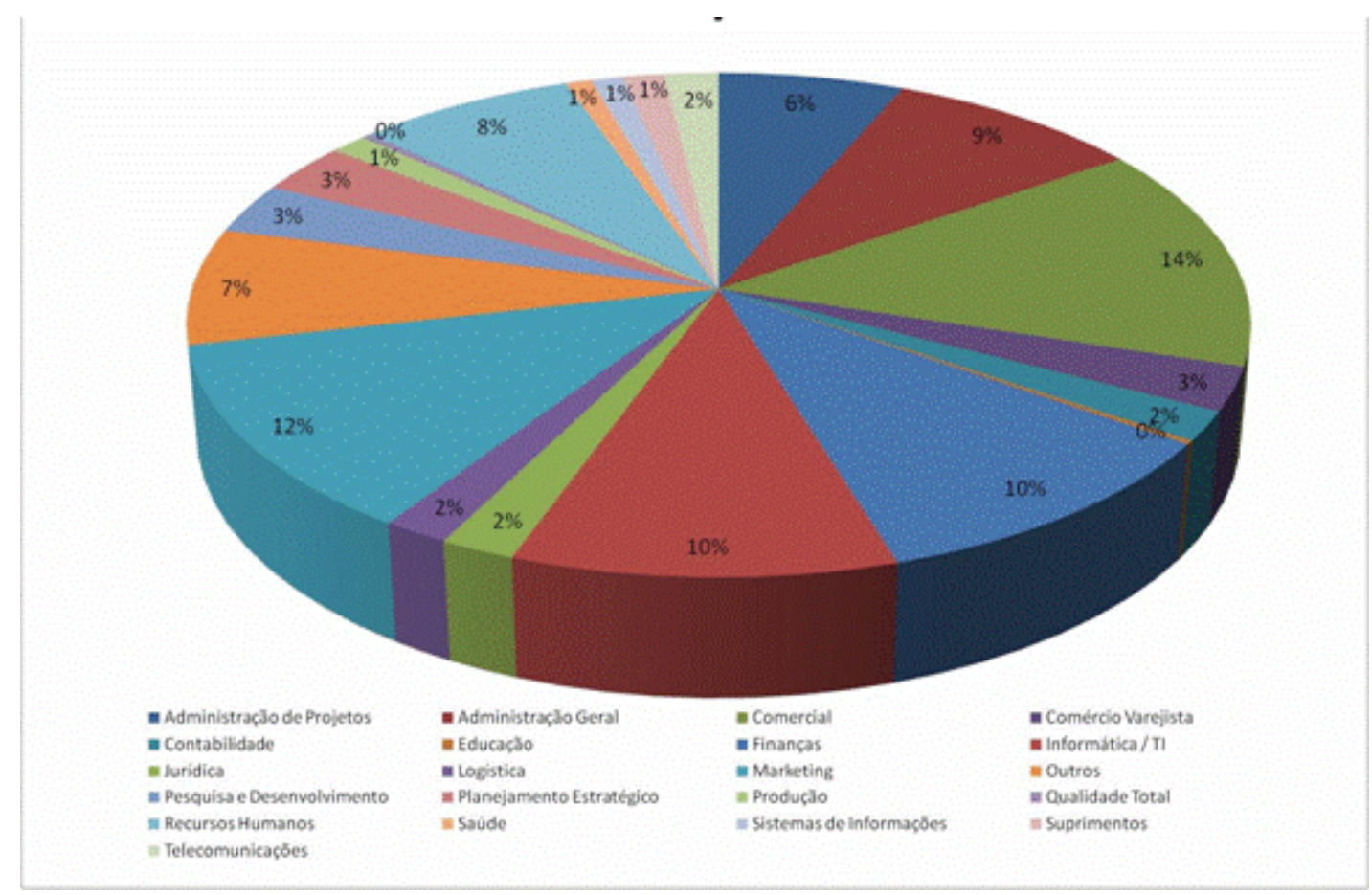

Gráfico 1: Área de atuação dos alunos FIA Fonte:FIA, 2009.

Os segmentos das empresas onde os alunos matriculados em 2008 trabalham compreendem: 


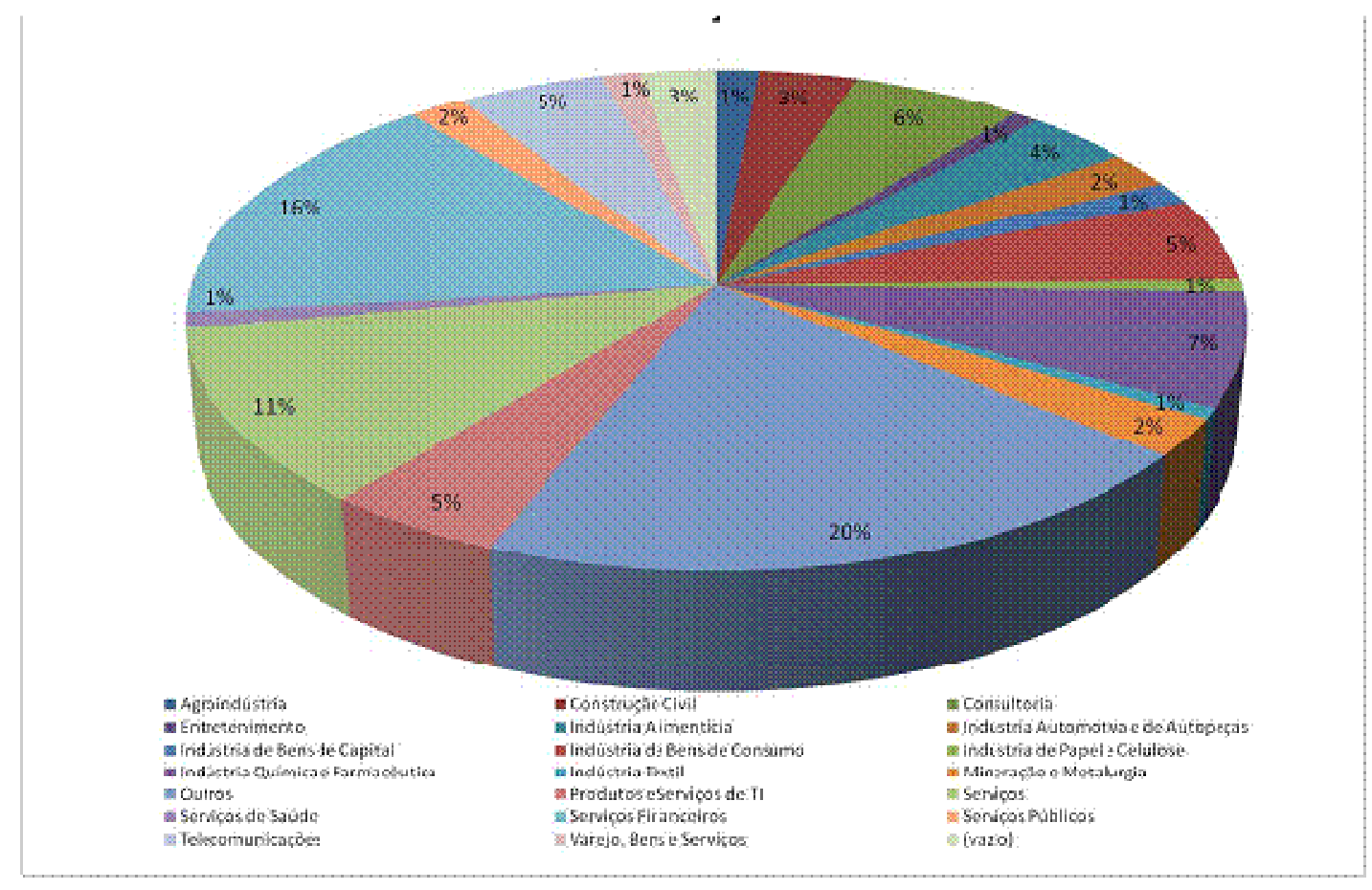

Gráfico 2: Segmento das empresas em que o aluno FIA trabalha Fonte: FIA, 2009.

Apresentadas as considerações em relação à populaça-alvo, a seção seguinte tratará dos aspectos relacionados à coleta de dados.

4.3 Procedimentos de coleta de dados

A seguir serão apresentados os instrumentos que comporão a coleta de dados para atingir os objetivos desta pesquisa e, em seguida, os passos para a coleta de dados. 


\subsubsection{O instrumento de coleta de dados}

Para atingir os objetivos estabelecidos para esta pesquisa, assim como testar as hipóteses, são necessários dois instrumentos distintos. O primeiro refere-se ao levantamento de informações sobre os Contratos Psicológicos e, o segundo, à identificação dos tipos psicológicos do indivíduo. Segue a descrição de tais instrumentos.

\section{a) Dos Contratos Psicológicos}

De acordo com Selltiz (1974), o questionário, a entrevista e o método projetivo são mais eficientes para dar informações sobre percepções, crenças, sentimentos, motivações, previsões ou planos da pessoa (SELLTIZ 1974, p. 262). Dados os objetivos centrais desta tese que são: 1) o exame da influência que os tipos psicológicos têm na captura e entendimento dos Contratos Psicológicos; 2) o exame da existência de associação entre tipo psicológico e a classificação dos Contratos Psicológicos; 3) o exame da existência de associação entre o tipo psicológico e o comportamento do indivíduo quando este se depara com o não cumprimento do Contrato Psicológico, e as hipóteses apresentadas anteriormente, define-se o questionário como o instrumento de coleta mais adequado, dadas as vantagens definidas por Selltiz (1974).

Como primeiro passo para a construção do questionário, estabeleceu-se uma divisão do mesmo em quatro partes, cada um cumprindo diferentes objetivos.

A primeira parte, seção I, coleta informações sobre dados pessoais (idade, gênero, tempo de experiência profissional na empresa atual, área e setor de atuação na empresa em que trabalha), acadêmicos (formação acadêmica). O tipo psicológico do indivíduo já é previamente conhecido e, portanto, não foi necessário coletá-lo nesta seção.

A segunda parte do questionário, seção II, foi construída visando o atendimento parcial da seqüência lógica apresentada no diagrama 2 a seguir. Parcial porque foram consideradas somente as etapas de cor preta. 


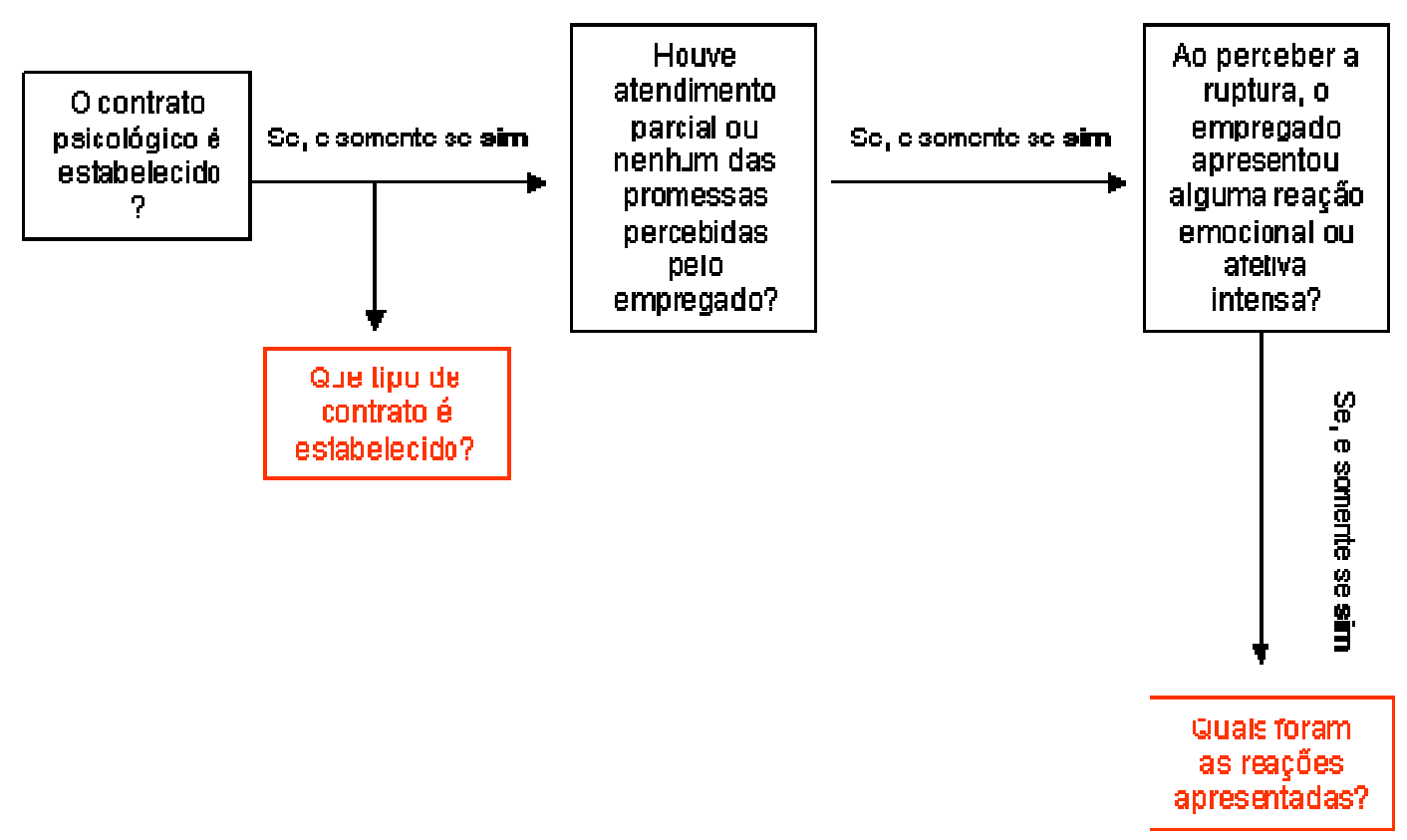

Diagrama 2: Etapas entre o processo de elaboração do Contrato Psicológico e sua violação. Fonte: autoria própria.

Para atender as etapas indicadas pela cor preta do diagrama 2, construiram-se quatro colunas. A primeira, denominada "Coluna Indicadores", apresenta o conteúdo dos Contratos Psicológicos, que foram extraídos de Rousseau (1990), Herriot, Manning e Kidd (1997) e Menegon (2004) e estão apresentados integralmente no referencial teórico desta tese (pp. 3032). Como exemplo, pode-se citar: "pagamento associado à alta performance", "atendimento às necessidades pessoais", "aceitação da diversidade" e assim por diante.

A próxima, chamada de "Coluna A", avalia em que grau houve a percepção de promessa para cada um dos conteúdos apresentados na "Coluna Indicadores". Para tanto, utilizou-se a escala intervalar em que 1 - não prometeu; 2 - insinuou levemente; 3 - deixou forte impressão de promessa, mas nenhuma promessa efetiva e 4 - Prometeu escrita ou verbalmente. Somente para aqueles conteúdos da "Coluna Indicadores" em que o respondente indicou 3 ou 4 na "Coluna A", ele deve responder a "Coluna B”. Nesta última, o respondente é questionado se a organização atendeu às promessas. Novamente fez-se uso da escala intervalar, sendo que: 4 - Excedeu; 3 -Atendeu; 2 - Atendeu parcialmente e 1 - Não atendeu. Para aqueles conteúdos da "Coluna B" que apresentarem respostas 2 ou 1, os respondentes deverão ir para a "Coluna C". Nesta, indaga-se se o respondente, ao perceber não atendimento, ou atendimento parcial, apresentou alguma reação emocional ou afetiva intensa. Lançou-se mão da escala nominal, sendo que o número 1 representou o SIM e o número 2 
representou o NÃO. Ao término da "Coluna C", o respondente é solicitado a responder uma questão geral intitulada "W", pela qual indica, também em escala nominal Sim e Não, se ao analisar globalmente os itens não atendidos ou atendidos parcialmente na "Coluna B", ele sentiu-se lesado pela organização com que atualmente possui relação de trabalho. O objetivo desta questão "W" é captar o nível de importância dada pelo respondente aos itens em que, na “Coluna B", respondeu "não atendeu" e "atendeu parcialmente".

Ao terminar de responder por completo a seção II, o respondente encaminha-se para a seção III, a qual tem por objetivo responder a questão "Quais foram as reações apresentadas?" de uma das partes identificadas em vermelho do diagrama 2, ou seja, a idéia é avaliar as autoreações do indivíduo frente à empresa por meio de onze itens avaliados. Nesta seção, solicitase ao respondente analisar tais sentenças considerando-se uma escala de 10 pontos em que 0 (zero) equivale à absoluta discordância e 10, à absoluta concordância. As sentenças foram construídas com o objetivo de identificar as reações apresentadas pelos empregados. Para tanto, utilizaram-se as reações de maior significância levantadas nos estudos de Menegon (2004) e Peyrat-Guillard (2008). O conjunto total das reações está mencionado na Fundamentação Teórica (p. 40) e, para o questionário, foram consideradas as seguintes: vingança, mágoa, raiva/ódio, depressão, ansiedade, traição e revolta. Ressalta-se que as sentenças foram distribuídas aleatoriamente no questionário.

A quarta parte do questionário, seção IV, foi construída com o objetivo de responder à questão “Que tipo de contrato é estabelecido?" de uma das partes identificadas em vermelho no diagrama 2, ou seja, se o contrato é relacional ou transacional. Para mensurar tal classificação, foram elaboradas, inicialmente, 28 sentenças com termos que representassem o continuum do Contrato Psicológico desenvolvido por Rousseau (1995), apresentado no referencial teórico desta tese (pp. 35-36). Exemplos são: "Econômico" (termo transacional) e "Emocional" (termo relacional) para o continuum "Foco".

Exemplo de sentença representativa do contrato relacional para o continuum "Escopo" é: “A empresa deve se preocupar com meu bem-estar e de minha família”. Exemplo do contrato transacional para o continuum escopo é: "Qualquer treinamento de que eu participe deve estar exclusivamente associado ao trabalho que realizo na organização".

Da mesma forma que na seção III, solicitou-se ao respondente analisar as 28 sentenças considerando-se uma escala de 10 pontos em que 0 (zero) equivale à absoluta discordância e 10, à absoluta concordância. 
É importante ressaltar que as sentenças foram distribuídas aleatoriamente no questionário.

O questionário preliminar foi submetido à leitura de três profissionais do mercado, leigos no tema da tese, com o intuito de verificar a compreensão deles no processo de resposta do instrumento, bem como das sentenças estabelecidas. Foram necessárias 3 avaliações do instrumento até que houvesse concordância de que as modificações produzidas geravam a compreensão total dos três avaliadores. A seguir, discorrer-se-á sobre o instrumento que avaliará os tipos psicológicos.

b) Dos tipos psicológicos

O inventário Diagnóstico dos Tipos Psicológicos (DTP), elaborado por Casado (1998), se constitui num questionário auto-preenchível composto por 150 questões que identificam as preferências que refletem as diferenças individuais de traços de personalidade. (CASADO, 1998, p. 80). A autora baseou-se na teoria dos Tipos Psicológicos de Jung (apresentada em detalhes na seção 3.6 da Fundamentação Teórica), que trata das diferenças entre indivíduos como "dimensões dotadas de pólos opostos e complementares." (CASADO, 1998, p. 80). As 150 questões do questionário possuem duas alternativas de resposta cada uma, de modo a abarcar, em cada dimensão, a questão da oposição e complementaridade. Conforme a teoria Junguiana, os pólos opostos encontram-se em um indivíduo. Este apenas experimenta uma preferência por um ou outro. Assim, o inventário "apresenta pares de alternativas que representam os opostos para que o sujeito assinale a sua preferência." (CASADO, 1998, p. 81). A escolha por esta ferramenta fundamentou-se na argumentação de que o DTP foi cuidadosamente desenhado e voltado para os brasileiros, considerando-se a cultura deste país. A utilização de um instrumento estrangeiro não consideraria a linguagem brasileira, nem mesmo suas experiências culturais específicas.

O DTP passou por processo de validação, considerando a validade e precisão do instrumento. Foram verificadas as validades de conteúdo - por meio da comparação dos resultados obtidos pelo instrumento aos resultados obtidos na auto-avaliação; e do construto, por meio da aplicação da técnica projetiva. A precisão foi tratada por meio da comparação do percentual de acerto do instrumento brasileiro com o percentual de acerto de um instrumento consagrado para a língua inglesa falada nos Estados Unidos da América. (CASADO, 1998, p. 91). 
Como resultados, o DTP apresenta 16 tipos psicológicos.

Apresentados os instrumentos de coleta de dados, a seção seguinte tratará do processo de validação do instrumento elaborado para coletar informações acerca dos Contratos Psicológicos.

\subsection{O pré-teste}

Com o objetivo de tornar o instrumento válido, foi realizado o teste piloto. Após a finalização da confecção do questionário, momento em que os três avaliadores do questionário disseram não haver mais dúvida em relação à leitura e ao processo de resposta do mesmo, este foi aplicado em uma amostra piloto de 114 alunos de quatro turmas de um curso de pós-graduação lato sensu, que foram selecionadas em função da relação profissional próxima da autora desta tese e os professores responsáveis pelas turmas.

Antes da aplicação do questionário, a autora apresentou-se como aluna de doutorado da FEA-USP e explicou, sucintamente, que a pesquisa tinha por objetivo entender aspectos do relacionamento entre empregadores e empregados, e que a adesão não era compulsória. Do total de 117 presentes em todas as turmas, somente três alunos recusaram-se a responder ao questionário.

Foram aplicados 114 questionários dos quais foram utilizados 110 para o processo de validação. 


\subsubsection{A validação do instrumento}

O questionário de Contratos Psicológicos foi elaborado especificamente para atender os objetivos desta tese. Apesar de existirem diversos instrumentos produzidos em pesquisas internacionais que pudessem atender parcialmente às necessidades destes estudo, optou-se pela construção de um instrumento próprio que não somente atendesse aos objetivos particulares da tese, como também refletisse a linguagem, o comportamento e as experiências culturais específicas da população brasileira

Conforme mencionado anteriormente (pp. 73-75), a seção II do questionário foi elaborada com base em indicadores, representativos do conteúdo do Contrato Psicológico, extraídos da literatura e usados em pesquisas anteriores (Rousseau, 1990; Herriot, Manning e Kidd, 1997 e Menegon, 2004). Por se tratar de uma parte do questionário que analisa individualmente tais indicadores, não houve a necessidade de verificar se os mesmos são consistentes internamente. Isto porque a seção II explora situações de formação de Contrato Psicológico e ruptura dos mesmos, ou seja, fornece estímulos para que as pessoas se lembrem de situações, não abordando um conceito único.

As seções III e IV do questionário, que medem reações e atitudes, respectivamente, precisaram ser validadas, haja vista que cada uma delas explora um conceito único e, portanto, devem apresentar consistência interna.

De acordo com Selltiz (1974), o critério de validade diz respeito à capacidade de medir o que realmente se deseja medir.

É objetivo avaliar a seção III como sendo um instrumento apropriado para levantar e identificar sentimentos de violação do Contrato Psicológico do funcionário frente à empresa. "Uma medida principal usada para avaliar o modelo de mensuração é a confiabilidade [...]. Confiabilidade é uma medida da consistência interna dos indicadores do construto, descrevendo o grau que eles "indicam" o construto latente (não observado) em comum." (HAIR et al, 2006, p. 489).

Para medir a confiabilidade da seção III, lançou-se mão do alpha de Cronbach. Este coeficiente foi desenvolvido por J. L. Cronbach e, para efetuar seu cálculo, basta uma única aplicação do instrumento de medição, conforme ocorreu no teste piloto. Os valores produzidos pelo cálculo do coeficiente variam entre zero e um, ou entre 0 e $100 \%$, e quando 
$>70 \%$ indicam confiabilidade das medidas. O coeficiente é calculado pela seguinte expressão:

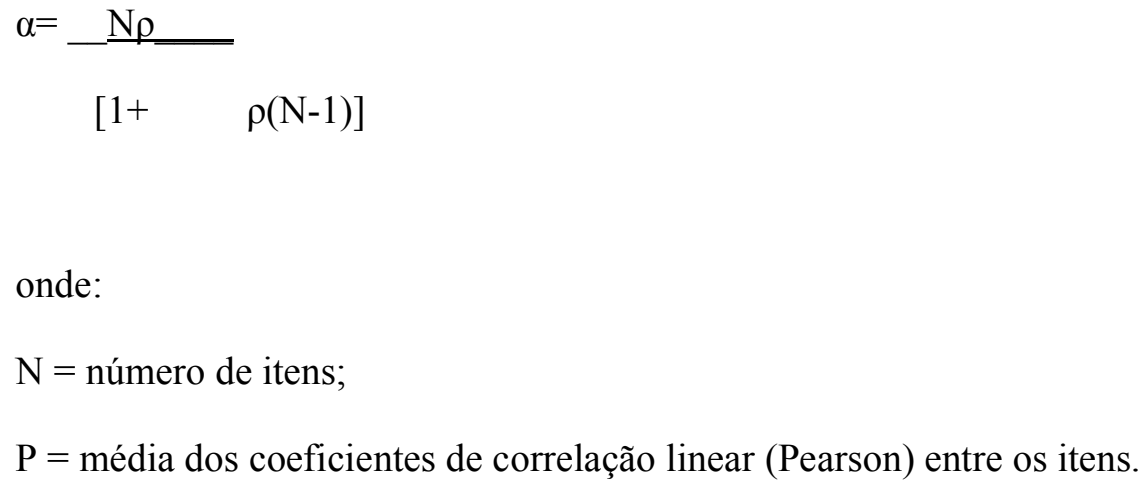

De acordo com Martins (2006):

são calculadas todas as correlações (p) entre o escore de cada item e o escore total dos demais itens. O valor de alpha é a media de todos os coeficientes de correlação. As correlações item-total e o valor do alpha de Cronbach são reveladores porque fornecem informações sobre cada item individual. Itens que não estão correlacionados com os demais podem ser eliminados da medida para aumentar a confiabilidade. (MARTINS, 2006, p. 5).

Neste estudo, o coeficiente alpha de Cronbach teve por objetivo correlacionar os onze itens presentes na seção III, que medem/avaliam as reações emocionais frente à empresa, diante de uma percepção de violação de promessa ocorrida. Ou seja, o alpha de Cronbach se refere à consistência interna do conjunto de onze expressões avaliando a confiabilidade num grupo de variáveis que se relacionam a um único conceito - reações emocionais frente à ruptura do Contrato Psicológico.

O alpha de Cronbach foi operacionalizado por meio do SPSS (Statistical Package for Social Sciences). Em termos de confiabilidade interna geral do instrumento, a seção III alcançou um coeficiente alpha de Cronbach de 0,915, acima de 0,70 (limite geralmente aceito). Para entender a obtenção deste coeficiente, faz-se necessária a apresentação da matriz de correlação do teste piloto da seção III e as explanações a seguir. 
Tabela 2: Matriz de correlação da seção III

$\begin{array}{lccccccccccc} & 1 . & 2 . & 3 . & 4 . & 5 . & 6 . & 7 . & 8 . & 9 . & 10 . & 11 . \\ \text { 1. } & 1 & 0,202 & 0,406 & 0,324 & 0,323 & 0,454 & 0,385 & 0,292 & 0,321 & 0,398 & 0,511 \\ \text { 2. } & 0,202 & 1 & 0,128 & 0,216 & 0,148 & 0,202 & 0,221 & 0,131 & 0,237 & 0,134 & 0,182 \\ \text { 3. } & 0,406 & 0,128 & 1 & 0,760 & 0,744 & 0,675 & 0,611 & 0,429 & 0,368 & 0,732 & 0,582 \\ \text { 4. } & 0,324 & 0,216 & 0,76 & 1 & 0,848 & 0,600 & 0,600 & 0,597 & 0,363 & 0,639 & 0,390 \\ \text { 5. } & 0,323 & 0,148 & 0,744 & 0,848 & 1 & 0,650 & 0,536 & 0,523 & 0,405 & 0,640 & 0,370 \\ \text { 6. } & 0,454 & 0,202 & 0,675 & 0,600 & 0,650 & 1 & 0,718 & 0,443 & 0,505 & 0,665 & 0,520 \\ \text { 7. } & 0,385 & 0,221 & 0,611 & 0,600 & 0,536 & 0,718 & 1 & 0,455 & 0,444 & 0,560 & 0,556 \\ \text { 8. } & 0,292 & 0,131 & 0,429 & 0,597 & 0,523 & 0,443 & 0,455 & 1 & 0,272 & 0,560 & 0,292 \\ \text { 9. } & 0,321 & 0,237 & 0,368 & 0,363 & 0,405 & 0,505 & 0,444 & 0,272 & 1 & 0,484 & 0,468 \\ 10 . & 0,398 & 0,134 & 0,732 & 0,639 & 0,640 & 0,665 & 0,560 & 0,560 & 0,484 & 1 & 0,660 \\ 11 . & 0,511 & 0,182 & 0,582 & 0,390 & 0,370 & 0,520 & 0,556 & 0,292 & 0,468 & 0,660 & 1\end{array}$

Fonte: autoria própria, com base em pesquisa para esta tese.

Considerando-se as onze sentenças da seção III (disponíveis no Apêndice 1), o coeficiente alpha de Cronbach inicial foi de 0,908, considerado alto. Portanto, foi possível validar a seção III do questionário, admitindo-se que as expressões de um a onze devem fazer parte de um instrumento que avalie a reação emocional referente a uma percepção de violação do Contrato Psicológico.

É objetivo, também, avaliar a seção IV como sendo um instrumento apropriado para levantar e identificar os tipos de Contrato Psicológico elaborados pelos indivíduos, podendo ser transacional ou relacional. O cálculo do coeficiente de alpha de Cronbach foi aplicado nesta seção e apresentou-se muito baixo, ou seja, apresentou baixa consistência interna, conforme é possível observar na tabela 3. 
Tabela 3: Matriz de correlação da seção IV

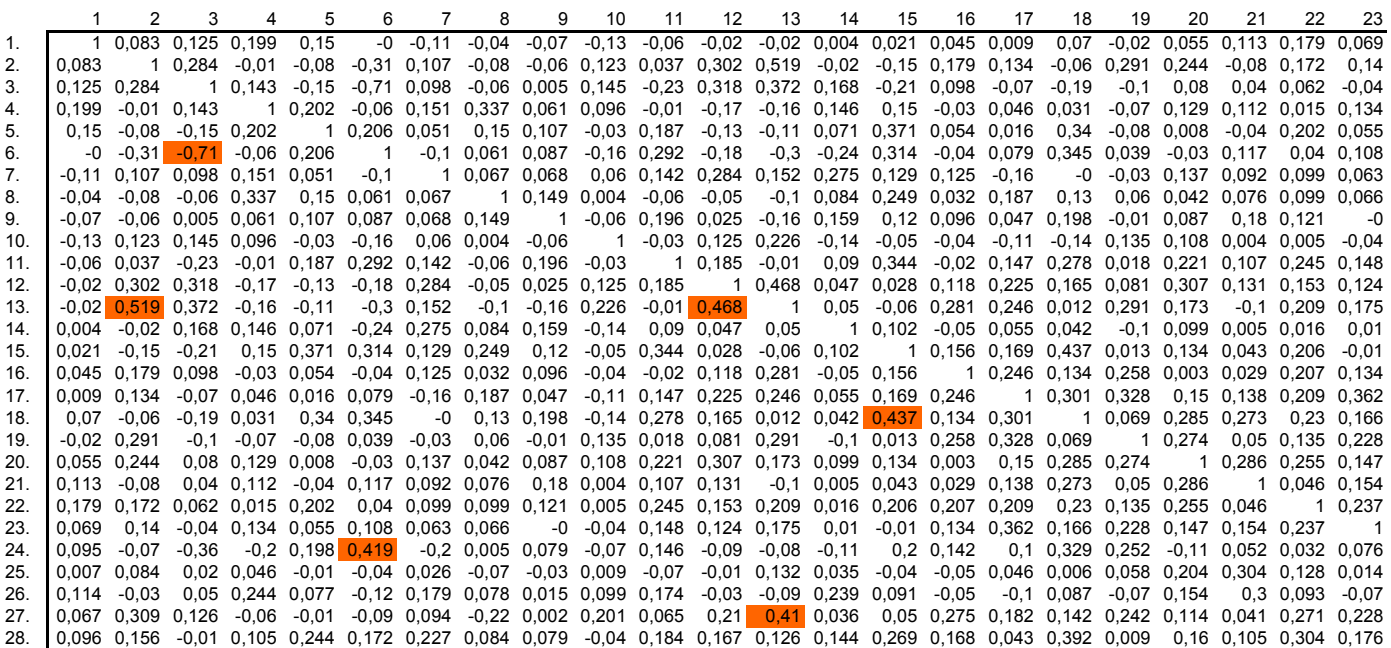

\begin{tabular}{|lrrrrr|}
\multicolumn{7}{l}{$r}$. & 24 & 25 & 26 & 27 & 28 \\
\hline 2. & 0,095 & 0,007 & 0,114 & 0,067 & 0,096 \\
3. & $-0,07$ & 0,084 & $-0,03$ & 0,309 & 0,156 \\
4. & $-0,36$ & 0,02 & 0,05 & 0,126 & $-0,01$ \\
5. & $-0,2$ & 0,046 & 0,244 & $-0,06$ & 0,105 \\
6. & 0,198 & $-0,01$ & 0,077 & $-0,01$ & 0,244 \\
7. & 0,419 & $-0,04$ & $-0,12$ & $-0,09$ & 0,172 \\
8. & $-0,2$ & 0,026 & 0,179 & 0,094 & 0,227 \\
8. & 0,005 & $-0,07$ & 0,078 & $-0,22$ & 0,084 \\
9. & 0,079 & $-0,03$ & 0,015 & 0,002 & 0,079 \\
10. & $-0,07$ & 0,009 & 0,099 & 0,201 & $-0,04$ \\
11. & 0,146 & $-0,07$ & 0,174 & 0,065 & 0,184 \\
12. & $-0,09$ & $-0,01$ & $-0,03$ & 0,21 & 0,167 \\
13. & $-0,08$ & 0,132 & $-0,09$ & 0,41 & 0,126 \\
14. & $-0,11$ & 0,035 & 0,239 & 0,036 & 0,144 \\
15. & 0,2 & $-0,04$ & 0,091 & 0,05 & 0,269 \\
16. & 0,142 & $-0,05$ & $-0,05$ & 0,275 & 0,168 \\
17. & 0,1 & 0,046 & $-0,1$ & 0,182 & 0,043 \\
18. & 0,329 & 0,006 & 0,087 & 0,142 & 0,392 \\
19. & 0,252 & 0,058 & $-0,07$ & 0,242 & 0,009 \\
20. & $-0,11$ & 0,204 & 0,154 & 0,114 & 0,16 \\
21. & 0,052 & 0,304 & 0,3 & 0,041 & 0,105 \\
22. & 0,032 & 0,128 & 0,093 & 0,271 & 0,304 \\
23. & 0,076 & 0,014 & $-0,07$ & 0,228 & 0,176 \\
24. & 1 & $-0,02$ & $-0,12$ & 0,02 & 0,208 \\
25. & $-0,02$ & 1 & 0,319 & 0,206 & 0,056 \\
26. & $-0,12$ & 0,319 & 1 & $-0,07$ & 0,08 \\
27. & 0,02 & 0,206 & $-0,07$ & 1 & 0,197 \\
28. & 0,208 & 0,056 & 0,08 & 0,197 & 1 \\
\hline
\end{tabular}

Fonte: autoria própria, com base em pesquisa para esta tese.

Do total de 378 coeficientes de correlação apresentados na tabela 3, apenas seis destes índices encontram-se acima de 0,40 (grifados na cor laranja). O restante está abaixo deste valor, demonstrando, em geral, uma baixa relação linear entre as variáveis.

O Alpha de Cronbach desta seção resultou no valor de 0,683, indicando, também, baoxa consistência interna entre as variáveis, pois ficou abaixo de 0,70. Frente a esses resultados e as análises realizadas, algumas sugestões de alteração das sentenças podem ser indicadas, e serão descritas a seguir, na tentativa de aumentar o valor do coeficiente Alpha de Cronbach. 
Primeiramente, considerou-se que questões com moda no ponto 5 da escala, ponto em que não há nem concordância nem discordância em relação à expressão, provavelmente são questões com problemas de entendimento. As seguintes questões, que estão acompanhadas de suas tabelas de freqüência, apresentaram problema, solucionados posteriormente. Tais procedimentos serão comentados adiante.

Tabela 4: Nem tudo o que precisa ser feito deve ser dito.

\begin{tabular}{|c|c|c|c|c|c|}
\hline & & Freqüência & Percentual & $\begin{array}{l}\text { Percentual } \\
\text { Válido }\end{array}$ & Percentual Cumulativo \\
\hline \multirow[t]{12}{*}{ Válidos } & 0 & 12 & 10,9 & 10,9 & 10,9 \\
\hline & 1 & 2 & 1,8 & 1,8 & 12,7 \\
\hline & 2 & 6 & 5,5 & 5,5 & 18,2 \\
\hline & 3 & 5 & 4,5 & 4,5 & 22,7 \\
\hline & 4 & 4 & 3,6 & 3,6 & 26,4 \\
\hline & 5 & 29 & 26,4 & 26,4 & 52,7 \\
\hline & 6 & 3 & 2,7 & 2,7 & 55,5 \\
\hline & 7 & 7 & 6,4 & 6,4 & 61,8 \\
\hline & 8 & 13 & 11,8 & 11,8 & 73,6 \\
\hline & 9 & 6 & 5,5 & 5,5 & 79,1 \\
\hline & 10 & 23 & 20,9 & 20,9 & 100,0 \\
\hline & Total & 110 & 100,0 & 100,0 & \\
\hline
\end{tabular}

Fonte: autoria própria, com base em pesquisa para esta tese. 
Tabela 5: Os termos de troca da relação de trabalho surgem com o tempo.

\begin{tabular}{|c|c|c|c|c|c|}
\hline & & Freqüência & Percentual & $\begin{array}{c}\text { Percentual } \\
\text { Válido }\end{array}$ & Percentual Cumulativo \\
\hline Válidos & 0 & 9 & 8,2 & 8,3 & 8,3 \\
\hline & 1 & 2 & 1,8 & 1,8 & 10,1 \\
\hline & 2 & 4 & 3,6 & 3,7 & 13,8 \\
\hline & 3 & 3 & 2,7 & 2,8 & 16,5 \\
\hline & 4 & 4 & 3,6 & 3,7 & 20,2 \\
\hline & 5 & 26 & 23,6 & 23,9 & 44,0 \\
\hline & 6 & 6 & 5,5 & 5,5 & 49,5 \\
\hline & 7 & 9 & 8,2 & 8,3 & 57,8 \\
\hline & 8 & 24 & 21,8 & 22,0 & 79,8 \\
\hline & 9 & 6 & 5,5 & 5,5 & 85,3 \\
\hline & 10 & 16 & 14,5 & 14,7 & 100,0 \\
\hline & Total & 109 & 99,1 & 100,0 & \\
\hline
\end{tabular}

Fonte: autoria própria, com base em pesquisa para esta tese.

Tabela 6: A minha relação com a empresa é econômica.

\begin{tabular}{|c|r|r|r|r|}
\hline & & & Percentual & \\
\hline Válidos & Freqüência & Percentual & Válido & Percentual Cumulativo \\
\hline 2 & 17 & 15,5 & 15,5 & 15,5 \\
3 & 9 & 8,2 & 8,2 & 23,6 \\
4 & 9 & 8,2 & 8,2 & 31,8 \\
5 & 5 & 4,5 & 4,5 & 36,4 \\
6 & 25 & 22,7 & 22,7 & 59,1 \\
7 & 4 & 3,6 & 3,6 & 62,7 \\
8 & 16 & 14,5 & 14,5 & 77,3 \\
9 & 16 & 14,5 & 14,5 & 91,8 \\
10 & 4 & 3,6 & 3,6 & 95,5 \\
Total & 5 & 4,5 & 4,5 & 100,0 \\
\hline
\end{tabular}

Fonte: autoria própria, com base em pesquisa para esta tese. 
Tabela 7: Qualquer contrato de trabalho, formal ou informal, deve ser flexível.

\begin{tabular}{|c|r|r|r|r|}
\hline & & & Percentual & \\
& Freqüência & Percentual & Válido & Percentual Cumulativo \\
\hline Válidos 0 & 10 & 9,1 & 9,1 & 9,1 \\
1 & 1 & 0,9 & 0,9 & 10,0 \\
2 & 5 & 4,5 & 4,5 & 14,5 \\
3 & 5 & 4,5 & 4,5 & 19,1 \\
4 & 5 & 4,5 & 4,5 & 23,6 \\
5 & 30 & 27,3 & 27,3 & 50,9 \\
6 & 10 & 9,1 & 9,1 & 60,0 \\
7 & 8 & 7,3 & 7,3 & 67,3 \\
8 & 13 & 11,8 & 11,8 & 79,1 \\
9 & 7 & 6,4 & 6,4 & 85,5 \\
10 & 16 & 14,5 & 14,5 & 100,0 \\
Total & 110 & 100,0 & 100,0 & \\
\hline
\end{tabular}

Fonte: autoria própria, com base em pesquisa para esta tese.

Tabela 8: Muito do que prometi à organização, e que a organização me prometeu, está implícito.

\begin{tabular}{|c|r|r|r|r|}
\hline & & & Percentual & \\
Válidos & Freqüência & Percentual & Válido & Percentual Cumulativo \\
\hline 1 & 17 & 15,5 & 15,5 & 15,5 \\
2 & 3 & 2,7 & 2,7 & 18,2 \\
3 & 4 & 3,6 & 3,6 & 21,8 \\
4 & 6 & 5,5 & 5,5 & 27,3 \\
5 & 3 & 2,7 & 2,7 & 30,0 \\
6 & 25 & 22,7 & 22,7 & 52,7 \\
7 & 11 & 10,0 & 10,0 & 62,7 \\
8 & 12 & 10,9 & 10,9 & 73,6 \\
9 & 18 & 16,4 & 16,4 & 90,0 \\
10 & 4 & 3,6 & 3,6 & 93,6 \\
Total & 7 & 6,4 & 6,4 & 100,0 \\
\hline
\end{tabular}

Fonte: autoria própria, com base em pesquisa para esta tese.

Paralelamente ao fato das questões anteriores apresentarem problemas, provavelmente relativos ao entendimento das mesmas, as questões a seguir apresentaram alto grau de concordância, conforme demonstram as tabelas que as acompanham. Como é possível observar na coluna da percentagem acumulada das tabelas (indicadas pelo grifo laranja), apenas $2 \%$ da amostra atribui escore 3 ou 4 (alguma discordância) às mesmas, indicando que as expressões não são polêmicas, que sugerem um lugar comum, muito provavelmente, não acrescentando qualquer informação valiosa. 
Tabela 9: Documentar acordos de trabalho realizados na organização é de fundamental importância para não gerar duplicidade de entendimento.

\begin{tabular}{|c|r|r|r|r|}
\hline & & & Percentual & Percentual \\
Vreqüência & Percentual & Cálo & Cumulativo \\
\hline Válidos 0 & 2 & 1,8 & 1,8 & 1,8 \\
3 & 1 & 0,9 & 0,9 & 2,7 \\
4 & 1 & 0,9 & 0,9 & 3,6 \\
5 & 8 & 7,3 & 7,3 & 10,9 \\
6 & 4 & 3,6 & 3,6 & 14,5 \\
7 & 10 & 9,1 & 9,1 & 23,6 \\
8 & 18 & 16,4 & 16,4 & 40,0 \\
9 & 9 & 8,2 & 48,2 \\
10 & 57 & 51,8 & 51,8 & 100,0 \\
Total & 110 & 100,0 & 100,0 & \\
\hline
\end{tabular}

Fonte: autoria própria, com base em pesquisa para esta tese.

Tabela 10: Qualquer mudança nas condições de trabalho deve ser negociada entre mim e a organização.

\begin{tabular}{|c|r|r|r|r|}
\hline & Freqüência & Percentual & Percentual & Percentual \\
& Válido & Cumulativo \\
\hline Válidos & 1 & 0,9 & 0,9 & 0,9 \\
4 & 1 & 0,9 & 0,9 & 1,8 \\
5 & 8 & 7,3 & 7,3 & 9,1 \\
6 & 4 & 3,6 & 3,6 & 12,7 \\
7 & 6 & 5,5 & 5,5 & 18,2 \\
8 & 15 & 13,6 & 13,6 & 31,8 \\
9 & 15 & 13,6 & 13,6 & 45,5 \\
10 & 60 & 54,5 & 54,5 & 100,0 \\
Total & 110 & 100,0 & 100,0 & \\
\hline
\end{tabular}

Fonte: autoria própria, com base em pesquisa para esta tese.

Além dos problemas mencionados anteriormente em relação à seção IV, outra observação pode ser feita. Algumas expressões foram elaboradas na $3^{\text {a }}$ pessoa, enquanto outras na $1^{a}$ pessoa, sugerindo um posicionamento do respondente. Tal redação pode ter confundido os respondentes em como se posicionar diante das mesmas, visto que ao responder um questionário, o indivíduo naturalmente compara as questões e expressões disponíveis. Portanto, foi realizada uma segunda validação do questionário, apresentada na seção seguinte. 


\subsubsection{A segunda validação do instrumento}

Diante dos problemas enfrentados pela primeira validação da seção IV, decidiu-se pela construção de um novo questionário. Para tanto, foram necessários alguns procedimentos. $\mathrm{O}$ primeiro deles foi uma reunião com cinco integrantes da amostra do primeiro pré-teste (110 respondentes). Solicitou-se que estas pessoas lessem novamente o questionário e tecessem observações quanto ao entendimento deles sobre cada uma das sentenças. De posse dos comentários, e de um breve retorno à literatura, construiu-se um novo questionário, considerando-se toda a análise estatística realizada, bem como os comentários tecidos pelo grupo. Este foi aplicado em uma amostra de 56 alunos do mesmo curso de pós-graduação lato sensu em que foi aplicado o primeiro pré-teste.

O cálculo do coeficiente de alpha de Cronbach também foi aplicado nesta seção, resultando em 0,732, o que indica boa consistência interna (acima de 0,70) entre as variáveis, sugerindo a validação da seção IV. Segue a matriz de correlação para análise descritiva.

Tabela 11: Matriz de correlação da seção IV - $2^{\text {a }}$ versão

\begin{tabular}{|c|c|c|c|c|c|c|c|c|c|c|c|c|c|c|c|c|c|}
\hline & 1 & 2 & 3 & 4 & 5 & 6 & 7 & 8 & 9 & 10 & 11 & 12 & 13 & 14 & 15 & 16 & 7 \\
\hline 1 & 1 & 0,21 & $-0,07$ & , 34 & 0,07 & 0,21 & $-0,07$ & 0,01 & $-0,03$ & 0,42 & $-0,03$ & 0,28 & 0,27 & $-0,02$ &, 14 & 0,13 & $-0,17$ \\
\hline 2 & 0,21 & 1 & 0,08 & 0,39 & 0,2 & 0,46 & $-0,03$ & 0,35 & 0,16 & 0,45 & 0,35 & $-0,29$ & 0,6 & 0,44 & $-0,42$ &, 41 & 17 \\
\hline 3 & $-0,07$ & 0,08 & 1 & 0,09 & 0,35 & 0,01 & 0,27 & 0,17 & 0,04 & 0,22 & 0,3 & 0,18 & 0,15 & 0,01 & 0,13 & 0,26 & 58 \\
\hline 4 & 0,34 & 0,39 & 0,09 & 1 & 0,26 & 0,26 & 0,13 & 0,23 & 0,11 & 0,41 & 0,1 & 0,1 & 0,33 & 0,32 & 0,02 & 0,28 & 0,03 \\
\hline 5 & 0,07 & 0,2 & 0,35 &, 26 & 1 & 0,15 & 0,25 & 0,15 & 0,03 & 0,39 & 0,06 & 0,22 & 0,44 & 0,14 & $-0,02$ & 0,48 & 0,16 \\
\hline 6 & 0,21 & 0,46 & 0,01 & 0,26 & 0,15 & 1 &, 14 & 0,35 & 0,23 & 0,29 & 0,14 & $-0,15$ & 0,3 & 0,26 & $-0,21$ & ,12 & 0,17 \\
\hline 7 & $-0,07$ & $-0,03$ & 0,27 & 0,13 & 0,25 & $-0,14$ & 1 & 0,18 & 0,06 & 0,1 & $-0,06$ & 0,38 & 0,09 & 0,12 & 0,38 & 0,13 & 0,1 \\
\hline 8 & 0,01 & 0,35 & 0,17 & 0,23 & 0,15 & 0,35 & 0,18 & 1 & 0,22 & 0,22 & 0,04 & $-0,11$ & 0,47 & 0,19 & $-0,11$ & 8 & 0,16 \\
\hline 9 & $-0,03$ & 0,16 & 0,04 & 0,11 & 0,03 & 0,23 & 0,06 & 0,22 & 1 & 0,3 & 0,38 & $-0,18$ & 0,34 & 0,18 & $-0,08$ & 0,23 & 0,21 \\
\hline 10 & 0,42 & 0,45 & 0,22 & 0,41 & 0,39 & 0,29 & 0,1 & 0,22 & 0,3 & 1 & 0,38 & -0 & 0,71 & 0,12 & $-0,1$ &, 53 & 0,18 \\
\hline 11 & $-0,03$ & 0,35 & 0,3 & 0,1 & 0,06 & 0,14 & $-0,06$ & 0,04 & 0,38 & 0,38 & 1 & $-0,27$ & 0,43 & 0,14 & $-0,28$ & 0,33 & 0,49 \\
\hline 12 & 0,28 & $-0,29$ & 0,18 & 0,1 & 0,22 & $-0,15$ & 0,38 & $-0,11$ & $-0,18$ & -0 & $-0,27$ & 1 & $-0,14$ & $-0,17$ & 0,6 & 0,01 & $-0,01$ \\
\hline 13 & 0,27 & 0,6 & 0,15 & 0,33 & 0,44 & 0,3 & 0,09 & 0,47 & 0,34 & 0,71 & 0,43 & $-0,14$ & 1 & 0,16 & $-0,3$ & 0,48 & 0,24 \\
\hline 14 & $-0,02$ & 0,44 & 0,01 & 0,32 & 0,14 & 0,26 & 0,12 & 0,19 & 0,18 & 0,12 & 0,14 & $-0,17$ & 0,16 & 1 & $-0,14$ & 0,11 & 0,12 \\
\hline- & 0,14 & $-0,42$ & 0,13 & 0,02 & $-0,02$ & $-0,21$ & 0,38 & $-0,11$ & $-0,08$ & $-0,1$ & $-0,28$ & 0,6 & $-0,3$ & $-0,14$ & 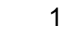 & $-0,12$ & $-0,04$ \\
\hline 16 & 0,13 & 0,41 & 0,26 & 0,28 & 0,48 & 0,12 & 0,13 & 0,18 & 0,23 & 0,53 & 0,33 & 0,01 & 0,48 & 0,11 & $-0,12$ & 1 & 0,35 \\
\hline 17 & $-0,17$ & 0,17 & 0,58 & 0,03 & 0,16 & 0,17 & 0,1 & 0,16 & 0,21 & 0,18 & 0,49 & $-0,01$ & 0,24 & 0,12 & $-0,04$ & 0,35 & 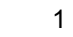 \\
\hline
\end{tabular}

Fonte: autoria própria, com base em pesquisa para esta tese.

Dos 136 coeficientes de correlação de Pearson, 18 deles (13\%) se encontram acima de 0,40 .

Apenas 2 expressões têm índices de correlação abaixo de 0,40, que seguem: 
(7) Minha relação com a organização é dificilmente compreendida por outras pessoas, pois muitos de seus aspectos são implícitos.

(9) Acredito que meu relacionamento com a organização seja de longo prazo, não sendo possível levantar possíveis causas para tal resultado., a não ser a própria relação entre as variáveis.

Para tanto, sugere-se a retirada destas duas questões do questionário.

Nenhuma expressão teve como moda o escore 5, como ocorreu no primeiro pré-teste, o que pode ser considerado um bom aspecto, tendo em vista o objetivo do projeto de classificação dos respondentes. Isto significa que o novo questionário conduz os respondentes a se posicionarem de alguma forma, sem, provavelmente, mal-entendidos. Assim, estabeleceu-se o questionário definitivo para a seção IV.

Conforme explicitado neste capítulo, as seções III e IV do questionário passaram por um processo de validação, de modo a garantir sua capacidade de medir o que deseja medir. Realizada esta etapa, é possível garantir maior confiabilidade dos resultados obtidos por meio da aplicação deste, podendo ser utilizado por outros pesquisadores que tenham interesse em prosseguir com pesquisas que tangenciem os objetivos trabalhados por esta tese.

Isto posto, o mesmo foi aplicado. Para tanto, a próxima seção tratará da coleta dos dados.

4.5 A coleta de dados

Conforme mencionado na seção 4.2, População-alvo, a amostra compreendeu alunos e ex-alunos da FIA que foram submetidos ao Diagnóstico de Tipos Psicológicos - DTP entre o ano de 2008 e o primeiro semestre de 2009, totalizando 528 alunos e ex-alunos. A escolha desta amostra não foi aleatória. A opção pela aplicação do questionário em modo eletrônico influenciou consideravelmente a escolha da mesma, haja vista a necessidade de possuir-se, de antemão, os resultados do tipo psicológico (dados secundários) de cada participante da pesquisa (foi necessário fazer o levantamento daqueles alunos que haviam sido submetidos ao DTP neste período).

Finalizado o questionário eletrônico, foi enviado um email (ver Apêndice 2) aos alunos e ex-alunos da FIA, explicando sucintamente a natureza da pesquisa e solicitando suas 
participações. Como forma de agradecer a contribuição, foi oferecida a oportunidade do respondente de participar de uma palestra com a apresentação dos resultados da pesquisa em data ainda a ser definida. Em seguida a este email, foi encaminhado o convite de participação da pesquisa (ver Apêndice 3), automaticamente disparado pelo software (plataforma do questionário), pelo qual a autora desta tese se apresentou, solicitando aos alunos e ex-alunos suas participações, fornecendo as instruções necessárias para o preenchimento da mesma e, principalmente, enviando o link da pesquisa. É importante ressaltar que cada participante da pesquisa recebeu um link pessoal e intransferível, de modo que fosse possível associar as respostas do questionário ao tipo psicológico do indivíduo, disposto na base de dados da amostra. O prazo de resposta do questionário foi de 15 dias, a contar da data de recebimento do convite. Nos primeiros cinco dias, foram obtidas 91 respostas. Percebeu-se, então, nos dias subseqüentes, uma paralisação da participação dos convidados. No oitavo dia, foi enviado um lembrete à amostra (ver Apêndice 4), solicitando a colaboração de todos, explicando a necessidade de um número mínimo de questionários a serem respondidos. Tal email surtiu efeito e, até o prazo final, foram respondidos 184 questionários, que representam uma taxa de $34,84 \%$ de respostas, considerado elevado frente à média de taxa de respostas geral, que costuma ficar em torno de $10 \%$.

Os resultados da pesquisa foram tabulados automaticamente pelo software, produzindo um documento em Excel, que continha a identificação dos respondentes (pelo endereço de email) e suas respostas. O cruzamento do tipo psicológico do indivíduo e os resultados do questionário de cada um deles foi realizado manualmente. Isto foi feito com o objetivo de preservar a identidade do respondente perante a empresa possuidora do software.

Apresentados os procedimentos de coleta de dados, faz-se necessária a discussão sobre as limitações metodológicas deste estudo.

\subsection{Limitações Metodológicas do Estudo}

Este estudo apresenta as limitações metodológicas, a saber: 
- a amostra pesquisada (não aleatória) não representa a totalidade de alunos e exalunos da FIA, mas somente aqueles que responderam à pesquisa, não sendo permitidas maiores extrapolações nas análises dos resultados;

- a realização da pesquisa por meio de uma ferramenta eletrônica, que permite ao respondente fazer pausas prolongadas no preenchimento dos questionários, pode interferir no processo de resposta do mesmo, uma vez que a atenção e concentração na seqüência de idéias desenvolvidas ao longo do questionário diminuem. As interrupções podem diminuir o comprometimento do respondente com as reflexões necessárias para o preenchimento do mesmo;

- parte da amostra pesquisada já foi alvo de outras pesquisas realizadas com temas correlatos, o que pode, por vezes, diminuir o esforço e comprometimento do respondente nesta pesquisa.

Expostas as limitações metodológicas deste estudo, o capítulo a seguir apresentará os resultados encontrados na pesquisa, bem como suas análises e interpretações, indicando os testes estatísticos necessários para o teste das hipóteses delineadas para esta tese. 


\section{Apresentação, Análise e Interpretação dos Resultados}

Para melhor entendimento da apresentação dos resultados, suas análises e interpretações, este capítulo se estruturará da seguinte forma. Primeiramente, serão apresentadas as características da amostra, baseando-se em uma análise descritiva dos resultados encontrados na seção I do questionário e, também, análises descritivas das respostas obtidas nas seções II, III e IV do questionário. Em seguida, serão testadas as hipóteses (a 95\% de confiança) delineadas para esta tese e, por último, serão tecidas as discussões dos resultados encontrados e as limitações do estudo.

\subsection{Características da amostra}

Os resultados apresentados a seguir referem-se aos dados coletados na "Seção I" do questionário aplicado. Vale lembrar que o tamanho da amostra corresponde a 184 respondentes.

Conforme é possível verificar na Tabela 12, em relação ao gênero, observa-se um leve equilíbrio entre os sexos masculino e feminino, que correspondem a $56 \%$ e $44 \%$ do número de respondentes, respectivamente.

Tabela 12: Gênero

\begin{tabular}{|lcc|}
\hline & Freqüência & $\%$ \\
Feminino & 81 & 44 \\
Masculino & 103 & 56 \\
Total & 184 & 100 \\
\hline
\end{tabular}

Fonte: autoria própria, com base em pesquisa para esta tese.

Segundo pesquisa realizada pelo Instituto Ethos (2006), a distribuição dos gêneros nos níveis hierárquicos de chefia e gerencial gira em torno de $70 \%$ para o sexo masculino e $30 \%$ para o feminino, enquanto para o nível hierárquico executivo $90 \%$ e $10 \%$, respectivamente. Pelo fato da amostra da pesquisa do Instituto Ethos contemplar níveis hierárquicos semelhantes, bem como idades muito aproximadas às desta tese, pode-se dizer que a amostra desta pesquisa mostrou-se bastante balanceada no quesito gênero. 
De acordo com a tabela 13, a amostra é composta apenas por pessoas que têm no mínimo superior completo; praticamente $70 \%$ da amostra tem pós- graduação completa e $10 \%$ têm mestrado (completo ou incompleto).

Tabela 13: Educação Formal

\begin{tabular}{|lccc|}
\hline & Freqüência & $\%$ & $\%$ acumulado \\
Superior completo & 7 & 3,8 & 3,8 \\
Pós-graduação incompleta & 32 & 17,4 & 21,2 \\
Pós-graduação completa & 127 & 69 & 90,2 \\
Mestrado incompleto & 6 & 3,3 & 93,5 \\
Mestrado completo & 12 & 6,5 & 100 \\
Total & 184 & 100 & \\
\hline
\end{tabular}

Fonte: autoria própria, com base em pesquisa para esta tese.

Conforme a tabela 14, a idade média dos respondentes é 36,7 anos (valor próximo da mediana), variando de 22 a 60 anos, 75\% dos respondentes têm idade inferior a 42 anos, o que indica alta concentração de jovens adultos nesta amostra. Também é possível observar nesta tabela que o tempo de experiência da amostra varia entre zero e 32 anos, e possui mediana de 7,5 anos (valor com maior representatividade da amostra, devido à existência de valores extremos superiores, que influenciam a média), e apresenta alta dispersão relativa - $86 \%$.

Tabela 14: Tempo de experiência e idade

\begin{tabular}{|c|c|c|c|c|c|c|c|c|}
\hline Tem & Mínimo & Máximo & Média & $\begin{array}{c}10 . \\
\text { Quartil }\end{array}$ & Mediana & $\begin{array}{c}30 . \\
\text { Quartil }\end{array}$ & $\begin{array}{l}\text { Desvio- } \\
\text { Padrão }\end{array}$ & $\begin{array}{c}\text { Coeficiente } \\
\text { de } \\
\text { Variação }\end{array}$ \\
\hline Experiência & 0 & 32 & 9,4 & 3,3 & 7,5 & 12,8 & 8,1 & $86 \%$ \\
\hline Idade & 22 & 60 & 36,7 & 30,0 & 36 & 42,0 & 8,2 & $22 \%$ \\
\hline
\end{tabular}

Fonte: autoria própria, com base em pesquisa para esta tese.

Com aproximadamente $70 \%$ dos respondentes tendo completado pós-graduação, mediana de 7,5 anos de experiência e mediana de 36 anos de idade, pode-se afirmar que a amostra revelou-se bastante adequada aos objetivos desta tese, uma vez que a mesma tende a apresentar bom nível de maturidade e preparo profissional. 
Em relação ao segmento de atuação no atual emprego, conforme é possível verificar na tabela $15,59.3 \%$ da amostra trabalha no setor relacionado a Serviços, $25.5 \%$ na Indústria, 5.4\% no Comércio e $9.8 \%$ em Outros.

Tabela 15: Distribuição da amostra no segmento atual de emprego

\begin{tabular}{|lrr|}
\hline & Freqüência & Percentual \\
Serviços & 109 & 59,3 \\
Comércio & 10 & 5,4 \\
Indústria & 47 & 25,5 \\
Outros & 18 & 9,8 \\
Total & 184 & 100 \\
\hline
\end{tabular}

Fonte: Autoria própria, como base em pesquisa para esta tese.

A tabela 16, a seguir, mostra a distribuição da amostra em sua área de atuação. Quase metade da amostra, 47,3\%, concentra-se nas seguintes áreas de atuação: Recursos Humanos, Comercial, Marketing.

Tabela 16: Distribuição da amostra na área de atuação

\begin{tabular}{|lrr|}
\hline & Freqüência & Percentual \\
Recursos Humanos & 28 & 15,2 \\
Comercial & 39 & 21,2 \\
Marketing & 20 & 10,9 \\
Administração & 66 & 35,9 \\
Produção & 2 & 1,0 \\
Outros & 29 & 15,8 \\
Total & 184 & 100 \\
\hline
\end{tabular}

Fonte: Autoria própria, como base em pesquisa para esta tese.

O perfil psicológico da amostra apresentou-se da seguinte forma: 
Tabela 17: Distribuição da amostra nos Tipos Psicológicos

\begin{tabular}{|lrr|}
\hline & Freqüência & Percentual \\
ISTJ & 25 & $13,6 \%$ \\
ISTP & 5 & $2,7 \%$ \\
ESTP & 7 & $3,8 \%$ \\
ESTJ & 37 & $20,1 \%$ \\
ISFJ & 7 & $3,8 \%$ \\
ISFP & 7 & $3,8 \%$ \\
ESFP & 10 & $5,4 \%$ \\
ESFJ & 15 & $8,2 \%$ \\
INFJ & 3 & $1,6 \%$ \\
INFP & 7 & $3,8 \%$ \\
ENFJ & 8 & $4,3 \%$ \\
INTJ & 8 & $4,3 \%$ \\
INTP & 6 & $3,3 \%$ \\
ENTP & 15 & $8,2 \%$ \\
ENFP & 16 & $8,7 \%$ \\
ENTJ & 7 & $3,8 \%$ \\
Total & 183 & $99,5 \%$ \\
Sem & & \\
resposta & 1 & $0,5 \%$ \\
Total & 184 & $100,0 \%$ \\
\hline
\end{tabular}

Fonte: autoria própria, com base em pesquisa para esta tese.

Conforme é possível observar na Tabela 17, a amostra tem maior concentração para os tipos ISTJ (13,6\%) e ESTJ (20,1\%), enquanto a distribuição dos tipos restantes é mais dispersa. A amostra (apesar de não ser representativa da população) seguiu um padrão esperado frente à população (pessoas que trabalham em empresas), considerando-se que as empresas têm maior preferência por estes dois tipos. (Calegari e Gemignani, 2006). Ademais, estudos acadêmicos realizados no Brasil como Casado (1998) e Zacharias (2006) encontraram, em suas amostras, padrões semelhantes.

Apresentadas as características da amostra, a seção seguinte tratará das análises descritivas das Seções II, III e IV do questionário. 
5.2 Análises descritivas do questionário

\subsubsection{Análise descritiva da seção II}

Os resultados apresentados a seguir referem-se aos dados coletados na "Seção II" do questionário aplicado.

Esta seção preocupou-se em responder às etapas entre o processo de elaboração do Contrato Psicológico e sua violação, apresentado no Diagrama 2 dos Procedimentos Metodológicos (p. 74). Para tanto, dividiu-se o questionário em quatro colunas. A primeira delas, denominada "Coluna Indicadores", dispõe o conteúdo dos Contratos Psicológicos, apresentados na seção 3.4 da Fundamentação Teórica. A segunda, denominada Coluna A, avalia em que grau houve a percepção de promessa para cada um dos conteúdos apresentados na "Coluna Indicadores". Os resultados relativos à segunda coluna estão demonstrados no gráfico 3, que segue. 


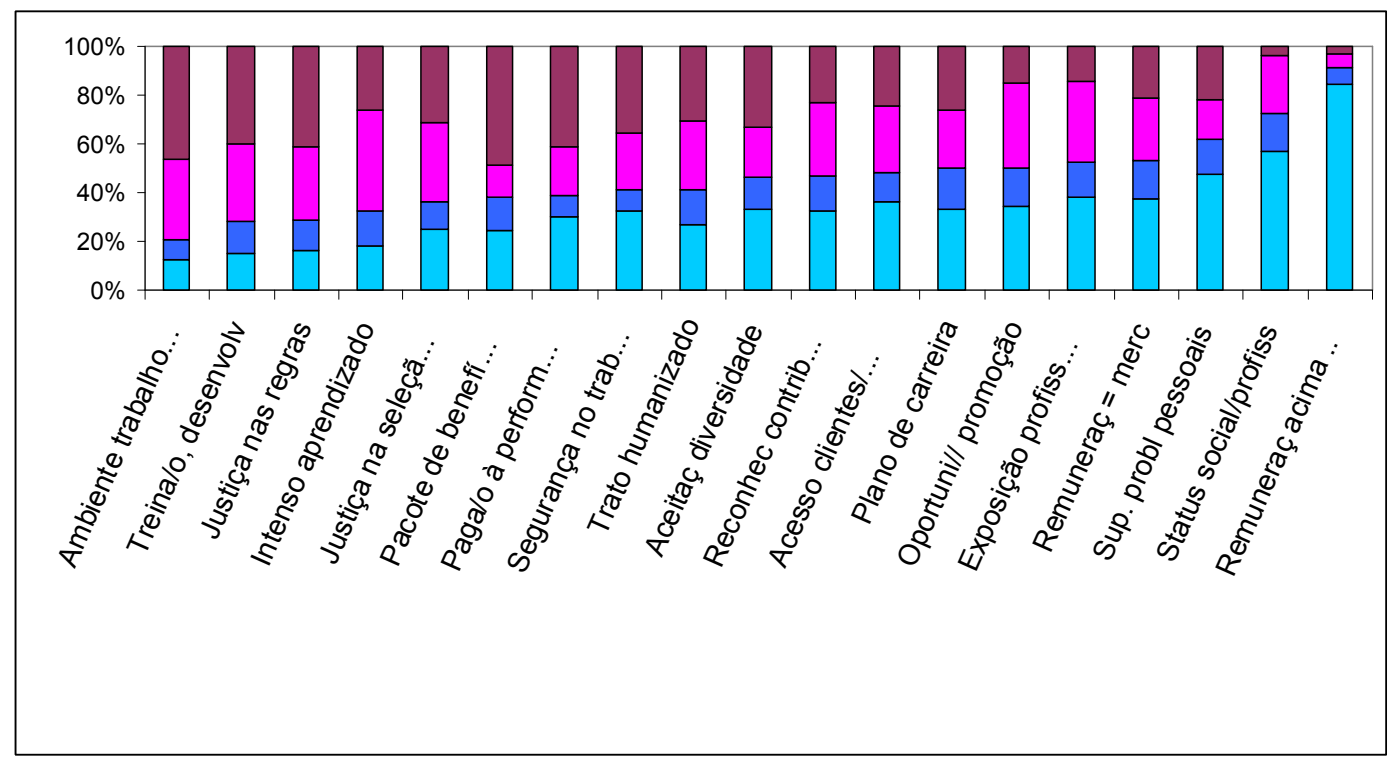

Gráfico 3: Distribuição de freqüência relativa aos Indicadores Representativos dos Contratos Psicológicos - Coluna A da Seção II do questionário.

Fonte: autoria própria, com base em pesquisa para esta tese.

Legenda

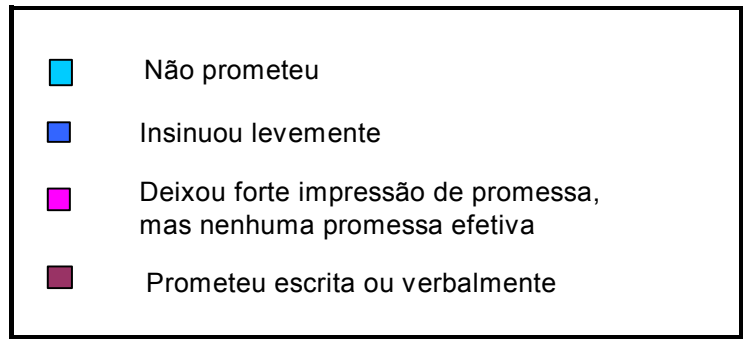

Para a questão presente na coluna $\mathrm{A}$, a percentagem está calculada com uma base de 177 respondentes, pois sete pessoas da amostra total deixaram de respondê-la. Analisando-se os resultados apresentados no gráfico 3, é possível concluir que Contratos Psicológicos tais como "remuneração acima do mercado", "status social e profissional", "suporte a problemas pessoais e/ou familiares" (atributos que se encontram mais à direita do eixo horizontal) são relativamente mais raros, visto que apresentaram percentuais de "não prometeu" iguais a $84,2 \%, 57,1 \%$ e $47,5 \%$, respectivamente. Os indicadores de Contrato Psicológico que foram proporcionalmente mais entendidos como "prometidos escrita e verbalmente" são promessas de "ambiente de trabalho" (46,3\%), "treinamento e desenvolvimento" (40,1\%), "justiça na aplicação das regras e disciplina da organização" (41,2\%), "pacote de benefícios" (48, 6\%) e "pagamento associado à alta performance" $(41,2 \%)$. Ou seja, estes indicadores apresentamse, de acordo com parte expressiva das respostas da amostra, como sendo parte dos Contratos Psicológicos explícitos estabelecidos entre indivíduo e organização. O que mais chama a 
atenção nas respostas da Coluna $\mathrm{A}$, entretanto, é o número considerável de indicadores do Contrato Psicológico que são considerados Contratos Psicológicos implícitos, ou seja, que obtiveram grande número de respostas "insinuou levemente" ou "deixou forte impressão de promessa, mas nenhuma promessa efetiva”. A somatória dos percentuais destes dois tipos de respostas para os indicadores "intenso aprendizado", "oportunidade de promoção" e “exposição profissional” é, respectivamente, 55,4\%, 50,3\% e 48\%. É importante salientar que destes percentuais, todos têm maior número de respostas "deixou forte impressão de promessa, mas nenhuma promessa efetiva" (no mínimo 68\% das respostas). Os indicadores "ambiente de trabalho idôneo e seguro", "treinamento e desenvolvimento", "justiça na aplicação das regras e disciplina da organização", "justiça nos processos de seleção, avaliação, promoção e outros procedimentos relacionados", "tratamento humanizado", "reconhecimento por contribuições especiais", "plano de carreira" e "remuneração equivalente ao mercado e na organização" apresentaram somatórias de "insinuou levemente" ou "deixou forte impressão de promessa, mas nenhuma promessa efetiva" entre 39\% e 44,6\%.

A terceira coluna de questões, denominada Coluna B, avalia se as promessas indicadas pelos respondentes na Coluna A são atendidas. Foram entendidas como promessas efetivamente realizadas aquelas que o respondente indicou "deixou forte impressão de promessa, mas nenhuma promessa efetiva" e "prometeu escrita ou verbalmente". Apesar da resposta "insinuou levemente" poder ser considerada uma percepção de promessa, ou seja, um Contrato Psicológico, optou-se por este corte, para se ter certeza de que o respondente estava completamente convicto do que havia sido prometido a ele. Com isso, será possível analisar melhor as respostas da coluna seguinte, a C. Os resultados obtidos para esta coluna B estão apresentados no gráfico 4 , a seguir. 


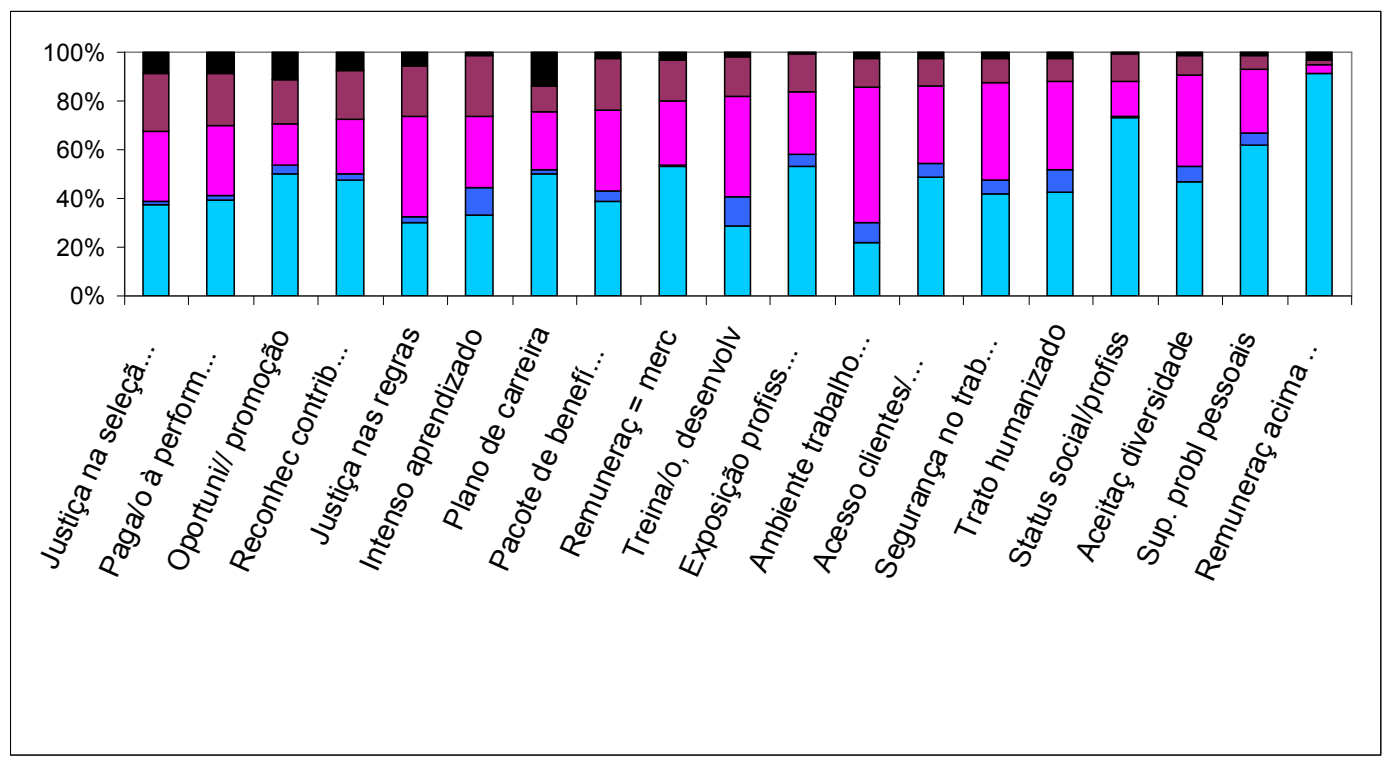

Gráfico 4: Distribuição da freqüência relativa ao atendimento das promessas - Coluna B da Seção II do questionário.

Fonte: autoria própria, com base em pesquisa para esta tese.

Legenda

\begin{tabular}{|ll|}
$\square$ & Não atendeu \\
$\square \quad$ Atendeu parcialmente \\
$\square \quad$ Atendeu \\
$\square \quad$ Excedeu \\
$\square \quad$ Não prometeu/insinuou levemente \\
\hline
\end{tabular}

Observa-se, no gráfico 4, que os percentuais indicados em azul não são considerados para análise, tendo em vista que na coluna $\mathrm{A}$, os respondentes indicaram "não prometeu" e "insinuou levemente". Os indicadores do Contrato Psicológico que obtiveram maior grau de não atendimento foram: "justiça nos processos de seleção, avaliação, promoção e outros procedimentos relacionados" (8,5\%); "pagamento associado à alta performance" $(8,5 \%)$; "oportunidade de promoção" (11,3\%); "reconhecimento por contribuições especiais e/ou inovadoras" (7,3\%); "justiça na aplicação das regras e disciplinas da organização" $(5,6 \%)$ e "plano de carreira" (13,6\%). Destes, "justiça nos processos de seleção, avaliação, promoção e outros procedimentos relacionados", "pagamento à alta performace" e "justiça na aplicação das regras e disciplinas da organização" apresentaram maior nível de promessa (entre 60 e $80 \%$ - ver gráfico 3$)$. 
É importante notar, também, que o indicador "oportunidade de promoção", apesar de ter alto percentual cumulativo para "Não prometeu" e "Insinuou levemente" (49,8\%), apresenta baixo cumprimento da mesma $(29,4 \%$ dos respondentes admitem não terem sido atendidos ou parcialmente atendidos). O mesmo ocorre para o indicador "plano de carreira", que apresenta baixo percentual de promessa (tanto quanto oportunidade de promoção $49,7 \%)$, e ainda assim, apresenta baixo cumprimento (24,3\% dos respondentes admitem não terem sido atendidos ou parcialmente atendidos). Este resultado pode indicar que mesmo aquilo que não está sendo prometido pela organização, está sendo percebido como não cumprido.

Ao se comparar os resultados do gráfico 3 e 4, é possível observar que os indicadores mais prometidos explicitamente (ou seja, prometidos escrita ou verbalmente) foram: "ambiente de trabalho idôneo e seguro" (46,3\%), "oportunidades de treinamento e desenvolvimento adequados" (40,1\%), "justiça na aplicação das regras e disciplinas da organização" (41,2\%), "pacote de benefícios atraente" $(48,6 \%)$ e "pagamento à alta performance" (41,42\%). Destes, conforme se observa na tabela $\& \&$, a seguir, somente o indicador "pagamento à alta performance" obteve percentuais de não atendimento/atendimento parcial $(29,9 \%)$ próximos ao de atendimento/excedeu $(30,5 \%)$. Pode-se concluir perante estes resultados que os Contratos Psicológicos explícitos tendem a ter maiores percentuais de atendimento do que não atendimento. Algo semelhante ocorre com os Contratos Psicológicos mais prometidos implicitamente (ou seja, insinuados ou que deixaram forte impressão de promessa): "intenso aprendizado", "oportunidade de promoção" e "exposição profissional" apresentaram os seguintes percentuais de promessas, respectivamente: 55,4\%, 50,3\% e 48\%. Mesmo para os indicadores do Contrato Psicológico que obtiveram altos percentuais de "insinuou" ou "deixou forte impressão de promessa", como "acesso a clientes e poder"; "tratamento humanizado"; "remuneração equivalente ao mercado e na organização"; "status social e profissional" e "reconhecimento por contribuições especiais e inovadoras", pode-se dizer que houve percentual de atendimento significativamente maior apenas para "tratamento humanizado", "acesso a clientes e poder" e "remuneração equivalente ao mercado". Os demais indicadores do Contrato Psicológico que tiveram alto percentual de promessa implícita apresentaram resultados equilibrados para atendimento e não atendimento. Isto posto, pode-se concluir que os Contratos Psicológicos implícitos tendem a ter maiores percentuais de atendimento do que não atendimento por parte das organizações. 
Tabela 18: Percentuais de indicadores atendidos e não atendidos

\begin{tabular}{|c|c|c|c|c|c|c|c|c|}
\hline & $\begin{array}{l}\text { Não } \\
\text { atendeu }\end{array}$ & $\begin{array}{l}\text { Atendeu } \\
\text { parcialmente }\end{array}$ & $\begin{array}{l}\text { Somatória de } \\
\text { não } \\
\text { atendimento }\end{array}$ & Atendeu & Excedeu & $\begin{array}{l}\text { Somatória de } \\
\text { atendimento }\end{array}$ & Total & $\begin{array}{l}\text { Não } \\
\text { prometeu/ } \\
\text { insinuou } \\
\text { levemente }\end{array}$ \\
\hline Oportunidade de promoção & 11,3 & 18,1 & 29,4 & 16,9 & 4,0 & 20,9 & 50,3 & 49,7 \\
\hline Remuneração equivalente mercado & 3,4 & 16,4 & 19,8 & 26,6 & 0,6 & 27,1 & 46,9 & 53,1 \\
\hline Remuneraç acima do mercado & 2,8 & 2,3 & 5,1 & 3,4 & 0,6 & 4,0 & 9,0 & 91,0 \\
\hline Pagamento à performance & 8,5 & 21,5 & 29,9 & 28,8 & 1,7 & 30,5 & 60,5 & 39,5 \\
\hline Treinamento e desenvolvimento & 1,7 & 16,4 & 18,1 & $\overline{41,2}$ & 11,9 & $\overline{53,1}$ & 71,2 & 28,8 \\
\hline Justiça na seleção/avaliação & 8,5 & 23,7 & 32,2 & 28,8 & 1,7 & 30,5 & 62,7 & 37,3 \\
\hline Plano de carreira & 13,6 & 10,7 & 24,3 & 23,7 & 1,7 & 25,4 & $4 \quad 49,7$ & 50,3 \\
\hline Segurança no trabalho & 2,3 & 10,2 & 12,4 & 40,1 & 5,6 & 45,8 & 58,2 & 41,8 \\
\hline Sup. probl pessoais & 1,1 & 5,6 & 6,8 & 26,6 & 4,5 & 31,1 & 137,9 & 62,1 \\
\hline Tratotamento humanizado & 2,3 & 9,6 & 11,9 & 36,2 & 9,6 & 45,8 & 37,6 & 42,4 \\
\hline Intenso aprendizado & 1,1 & 24,9 & 26,0 & 29,9 & 10,7 & 40,7 & $7 \quad 66,7$ & 33,3 \\
\hline Exposição profissional & 0,6 & 15,8 & 16,4 & 25,4 & 5,1 & 30,5 & 46,9 & 53,1 \\
\hline Acesso clientes/poder & 2,3 & 11,3 & 13,6 & $\overline{32,2}$ & 5,6 & 37,9 & 51,4 & 48,6 \\
\hline Status social/profissional & 0,6 & 11,3 & 11,9 & 14,7 & 0,6 & 15,3 & 27,1 & 72,9 \\
\hline Aceitação diversidade & 1,1 & 8,5 & 9,6 & 37,3 & 6,2 & 43,5 & 53,1 & 46,9 \\
\hline Reconhecimento à contribuições & 7,3 & 20,3 & 27,7 & 22,6 & 2,3 & 24,9 & 52,5 & 47,5 \\
\hline Ambiente trabalho idôneo e seguro & 2,3 & 11,9 & 14,1 & 55,9 & 7,9 & 63,8 & 378,0 & 22,0 \\
\hline Justiça nas regras & 5,6 & 20,9 & 26,6 & 41,2 & 2,3 & 43,5 & 70,1 & 29,9 \\
\hline Pacote de benefícios atrativos & 2,3 & 21,5 & 23,7 & 33,3 & 4,0 & 37,3 & 361,0 & 39,0 \\
\hline
\end{tabular}

Fonte: autoria própria, com base em pesquisa para esta tese.

A quarta coluna, denominada Coluna $\mathrm{C}$, indaga o respondente se, ao perceber não atendimento ou atendimento parcial na Coluna $\mathrm{B}$, apresentou alguma reação emocional ou afetiva intensa.

O gráfico 5 apresenta os resultados obtidos a partir das 177 respostas. 


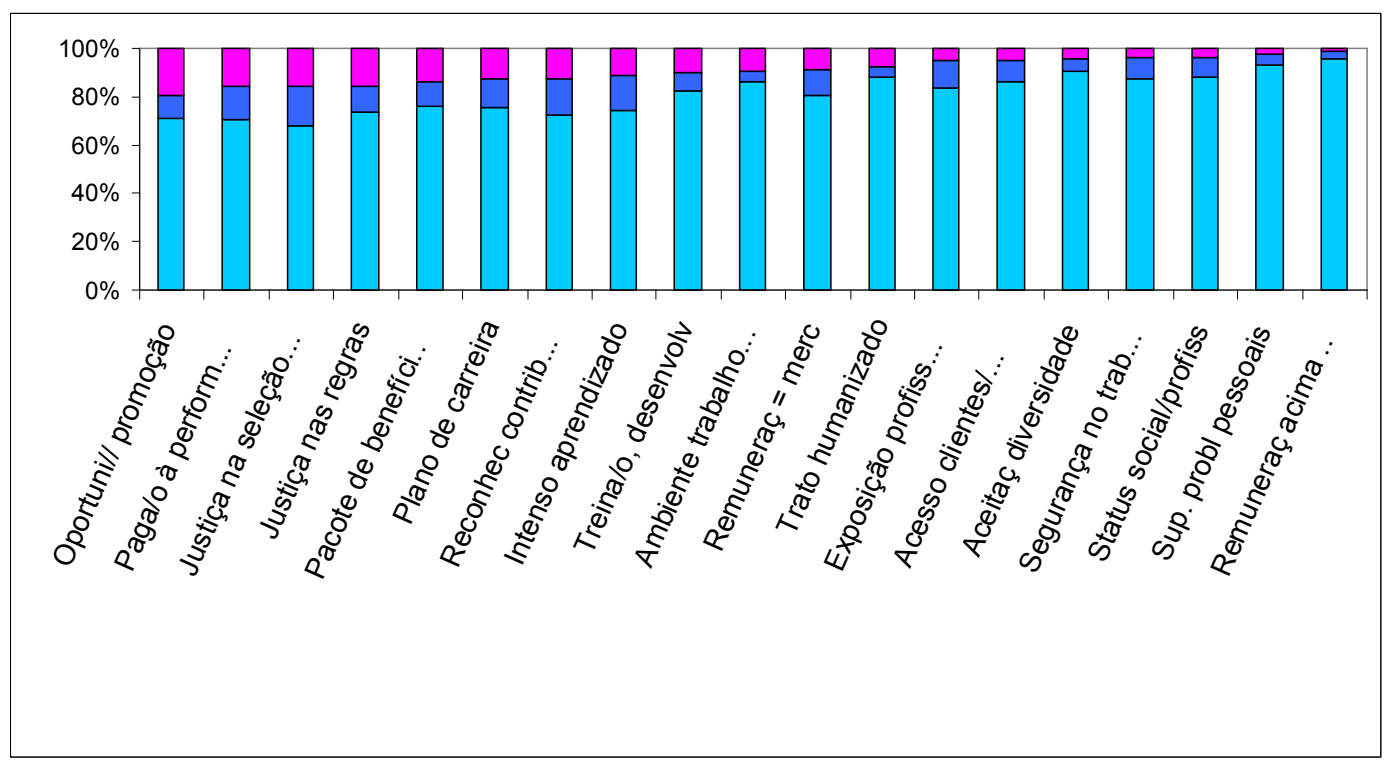

Gráfico 5: Distribuição da freqüência relativa à reação emocional ou afetiva intensa Fonte: autoria própria, com base em pesquisa para esta tese - Coluna C da Seção II do questionário.

Legenda

\begin{tabular}{|l|l|}
$\square$ & $\begin{array}{l}\text { Não prometeu/Insinuou levemente/ } \\
\text { atendeu ou excedeu a promessa }\end{array}$ \\
& Não \\
$\square$ & Sim
\end{tabular}

Observa-se, no gráfico 5, que os percentuais indicados em azul não são considerados para análise, tendo em vista que nas colunas anteriores (A e B), os respondentes indicaram "não prometeu" e "insinuou levemente"; "atendeu" e "excedeu" para o indicador em questão, condições que levam ao não preenchimento daquele na coluna $\mathrm{C}$.

Descritivamente, é possível notar que há maior percentual de reação emocional/afetiva quando a promessa se refere à oportunidade de promoção e não foi atendida ou atendida parcialmente (19,2\% dos respondentes - dado melhor observável na tabela 19).

Entre $14 \%$ a $15 \%$ dos que disseram apresentar alguma reação emocional/afetiva se referiam às seguintes promessas não atendidas satisfatoriamente: pagamento associado à alta performance, justiça nos processos de seleção, avaliação, promoção e outros procedimentos relacionados, justiça na aplicação das regras e disciplinas da organização, pacote de benefícios atrativos. Isto fica mais bem evidenciado na tabela 19. Os indicadores reconhecimento por contribuições especiais e/ou inovadoras e plano de carreira apresentaram- 
se em $4^{\circ}$ e $5^{\circ}$ lugar, respectivamente, quanto ao percentual de existência de reação frente ao não cumprimento da promessa. As demais posições estão, também, apresentadas na tabela 19.

Tabela 19: Percentuais de Indicadores não atendidos ou atendidos parcialmente que apresentaram reação emocional

\begin{tabular}{|c|c|c|c|c|}
\hline & $\begin{array}{c}\text { Não prometeu/ } \\
\text { insinuou } \\
\text { levemente/ } \\
\text { excedeu/atendeu }\end{array}$ & $\begin{array}{c}\text { Sem reação } \\
\text { emocional }\end{array}$ & $\begin{array}{c}\text { Com reação } \\
\text { emocional }\end{array}$ & $\begin{array}{c}\text { Posto das } \\
\text { reações }\end{array}$ \\
\hline Oportunidade de promoção & 71,2 & 9,6 & 19,2 & 1 \\
\hline Pagamento associado à alta performance & 70,6 & 13,6 & 15,8 & 2 \\
\hline Justiça nos processos de seleção, avaliação, promoção e outros procedimentos relacionados & 67,8 & 16,4 & 15,8 & 2 \\
\hline Justiça na aplicação das regras e disciplinas da organização & 73,4 & 10,7 & 15,8 & 2 \\
\hline Pacote de benefícios atrativos & 76,3 & 9,6 & 14,1 & 3 \\
\hline Plano de carreira & 75,7 & 11,9 & 12,4 & 4 \\
\hline Reconhecimento por contribuições especiais e/ou inovadoras & 72,3 & 15,3 & 12,4 & 4 \\
\hline Ambiente de intenso aprendizado & 74,0 & 14,7 & 11,3 & 5 \\
\hline Oportunidade de treinamento e desenvolvimento adequados & 82,5 & 7,3 & 10,2 & 6 \\
\hline Ambiente de trabalho idôneo e seguro & 85,9 & 4,5 & 9,6 & 7 \\
\hline Remuneração equivalente ao mercado e na organização & 80,8 & 10,2 & 9,0 & 8 \\
\hline Tratamento humanizado (responsável e oferecendo suporte ao empregado) & 88,1 & 4,5 & 7,3 & 9 \\
\hline Exposição profissional dentro e/ou fora da organização & 83,6 & 11,3 & 5,1 & 10 \\
\hline Acesso (a clientes, poder, informações privilegiadas entre outros) & 86,4 & 8,5 & 5,1 & 11 \\
\hline Aceitação da diversidade & 90,4 & 5,1 & 4,5 & 12 \\
\hline Segurança no trabalho & 87,6 & 8,5 & 4,0 & 13 \\
\hline Status social e profissional & 88,1 & 7,9 & 4,0 & 13 \\
\hline Suporte a problemas pessoais e/ou familiares & 93,2 & 4,5 & 2,3 & 14 \\
\hline Remuneração acima do mercado & 95,5 & 3,4 & 1,1 & 15 \\
\hline
\end{tabular}

Fonte: autoria própria, com base em pesquisa para esta tese.

Analisando-se conjuntamente os dados obtidos no gráfico 3 e tabela 19, é pouco provável que os percentuais de reações emocionais/afetivas (ou presença de violação do Contrato Psicológico) estejam relacionados à explicitude ou implicitude do Contrato Psicológico, pois tanto para aqueles indicadores que obtiveram maior percentual de respostas "prometeu escrita ou verbalmente" (ou seja, houve maior formação de Contratos Psicológicos explícitos) quanto para aqueles que responderam "insinuou" e "deixou forte impressão de promessa" (ou seja, houve maior formação de Contratos Psicológicos implícitos), os percentuais de reações emocionais/afetivas foram próximos.

A seção II termina com uma pergunta $\mathrm{W}$ que tem por objetivo captar o nível de importância dada pelo respondente aos itens em que, na "Coluna B", respondeu "não atendeu" e "atendeu parcialmente" e, com isso, entender se houve ruptura do Contrato Psicológico.

Da amostra, apenas 148 responderam esta questão. Dos respondentes, $41 \%$ se sentiram lesados pela organização, conforme é possível observar na tabela 20. 
Tabela 20: Distribuição de freqüência

\begin{tabular}{|lccc|}
\hline & Freqüência & $\%$ & $\%$ Válido \\
Sim & 61 & 33,2 & 41,2 \\
Não & 87 & 47,3 & 58,8 \\
Total & 148 & 80,4 & 100 \\
Sem & & & \\
resposta & 36 & 19,6 & \\
Total & 184 & 100 & \\
& & & \\
\hline
\end{tabular}

Fonte: autoria própria, com base em pesquisa para esta tese.

Acredita-se que a percepção do não atendimento ou atendimento parcial da promessa efetuada somente ocorre quando a promessa é entendida como relevante para o indivíduo. $\mathrm{O}$ que não é relevante para o respondente não é percebido, ou seja, não ocorre a percepção de lesão.

Para determinar qual o tipo de promessa é importante para o respondente, procederamse testes estatísticos (Qui-Quadrado) buscando associação significativa entre "sentir-se lesado" e "não atendimento ou atendimento parcial da promessa". 
Tabela 21: Níveis descritivos da Prova Qui-Quadrado

\begin{tabular}{|l|c|c|}
\hline Variável indicadora do Contrato Psicológico & $\chi^{2}$ & $\mathrm{p}$ \\
\hline P1B. Oportunidade de promoção & $24,, 132$ & $0,000\left(^{*}\right)$ \\
\hline P2B. Remuneração equivalente ao mercado e na organização & 3,919 & $0,048\left(^{*}\right)$ \\
\hline P3B. Remuneração acima do mercado & 1,581 & 0,209 \\
\hline P4B. Pagamento associado à alta performance & 8,982 & $0,003\left(^{*}\right)$ \\
\hline $\begin{array}{l}\text { P5B. Oportunidade de treinamento e desenvolvimento } \\
\text { adequados }\end{array}$ & 0,252 & 0,616 \\
\hline $\begin{array}{l}\text { P6B. Justiça nos processos de seleção, avaliação, promoção e } \\
\text { outros procedimentos relacionados }\end{array}$ & 10,644 & $0,001\left(^{*}\right)$ \\
\hline P7B. Plano de carreira & 9,269 & $0,002\left(^{*}\right)$ \\
\hline P8B. Segurança no trabalho & 1,895 & 0,169 \\
\hline P9B. Suporte a problemas pessoais e/ou familiares & 1,417 & 0,234 \\
\hline $\begin{array}{l}\text { P10B. Tratamento humanizado (responsável e oferecendo } \\
\text { suporte ao empregado) }\end{array}$ & 0,414 & 0,520 \\
\hline P11B. Ambiente de intenso aprendizado & 1,204 & 0,273 \\
\hline P12B. Exposição profissional dentro e/ou fora da organização & 0,194 & 0,659 \\
\hline $\begin{array}{l}\text { P13B. Acesso (a clientes, poder, informações privilegiadas } \\
\text { entre outros) }\end{array}$ & 0,002 & 0,961 \\
\hline P14B. Status social e profissional & 2,562 & 0,109 \\
\hline P15B. Aceitação da diversidade & 0,271 & 0,603 \\
\hline $\begin{array}{l}\text { P16B. Reconhecimento por contribuições especiais e/ou } \\
\text { inovadoras }\end{array}$ & 2,906 & 0,088 \\
\hline P17B. Ambiente de trabalho idôneo e seguro & 4,381 & $0,036\left(^{*}\right)$ \\
\hline $\begin{array}{l}\text { P18B. Justiça na aplicação das regras e disciplinas da } \\
\text { organização }\end{array}$ & 9,580 & $0,002\left(^{*}\right)$ \\
\hline P19B. Pacote de benefícios atrativos & 4,441 & $0,035\left(^{*}\right)$ \\
\hline
\end{tabular}

Fonte: autoria própria, com base em pesquisa para esta tese.

$\left.{ }^{*}\right) \mathrm{p}<0,05$, rejeitada hipótese de independência entre sentir-se lesado e falta de atendimento à promessa efetuada em determinados temas.

Conforme é possível observar na tabela 21 , sentir-se lesado está relacionado à falta de cumprimento de promessas em relação à:

- oportunidade de promoção;

- remuneração equivalente ao mercado e na organização;

- pagamento associado à alta performance;

- plano de carreira;

- justiça nos processos de seleção, avaliação, promoção e outros procedimentos relacionados;

- ambiente de trabalho idôneo e seguro; 
- justiça na aplicação das regras e disciplinas da organização e

- pacote de benefícios atrativos.

Estes resultados demonstram que tais indicadores do Contrato Psicológico são considerados importantes pela amostra respondente, haja vista a relação entre não atendimento e sentir-se lesado.

Os resultados de cada uma das variáveis (ou indicadores do Contrato Psicológico) que apresentaram associação entre não atendimento e sentir-se lesado estão dispostos nas tabelas seguintes.

Tabela 22: Distribuição conjunta de oportunidade de promoção não atendida/ parcialmente atendida e sentir-se lesado.

\begin{tabular}{|ll|c|c|c|}
\hline & & \multicolumn{2}{|c|}{$\begin{array}{c}\text { Você se sentiu lesado em } \\
\text { algum momento pela } \\
\text { organização? }\end{array}$} & \\
\cline { 3 - 4 } P1B.Oportunidade de promoção & & Sim & Não & Total \\
\hline atendeu/excedeu & frequência & 26 & 71 & 97 \\
& $\%$ & $42,6 \%$ & $81,6 \%$ & $65,5 \%$ \\
não atendeu/atendeu parcialmente & frequência & 35 & 16 & 51 \\
Total & $\%$ & $57,4 \%$ & $18,4 \%$ & $34,5 \%$ \\
& frequência & 61 & 87 & 148 \\
& $\%$ & $100,0 \%$ & $100,0 \%$ & $100,0 \%$ \\
\hline
\end{tabular}

Fonte: autoria própria, com base em pesquisa para esta tese.

Tabela 23: Distribuição conjunta de remuneração equivalente não atendida/ parcialmente atendida e sentir-se lesado.

\begin{tabular}{|c|c|c|c|c|}
\hline \multirow{2}{*}{\multicolumn{2}{|c|}{$\begin{array}{l}\text { P2B.Remuneração equivalente ao mercado e na } \\
\text { organização }\end{array}$}} & \multicolumn{2}{|c|}{$\begin{array}{l}\text { Você se sentiu lesado em } \\
\text { algum momento pela } \\
\text { organização? }\end{array}$} & \multirow[b]{2}{*}{ Total } \\
\hline & & Sim & Não & \\
\hline $\begin{array}{l}\text { atendeu/excedeu } \\
\text { não atendeu/atendeu parcialmente }\end{array}$ & $\begin{array}{l}\text { frequência } \\
\% \\
\text { freauência } \\
\%\end{array}$ & $\begin{array}{c}42 \\
68,9 \% \\
19 \\
110\end{array}$ & $\begin{array}{c}72 \\
82,8 \% \\
15\end{array}$ & $\begin{array}{c}114 \\
77,0 \% \\
34\end{array}$ \\
\hline Total & $\begin{array}{l}\text { frequência } \\
\%\end{array}$ & $\begin{array}{c}61 \\
100,0 \% \\
\end{array}$ & $\begin{array}{c}87 \\
100,0 \% \\
\end{array}$ & $\begin{array}{c}148 \\
100,0 \%\end{array}$ \\
\hline
\end{tabular}

Fonte: autoria própria, com base em pesquisa para esta tese. 
Tabela 24: Distribuição conjunta de pagamento associado à alta performance não atendida/ parcialmente atendida e sentir-se lesado.

\begin{tabular}{|c|c|c|c|c|}
\hline \multirow{2}{*}{\multicolumn{2}{|c|}{ P4B.Pagamento associado à alta performance }} & \multicolumn{2}{|c|}{$\begin{array}{l}\text { Você se sentiu lesado em } \\
\text { algum momento pela } \\
\text { organização? }\end{array}$} & \multirow[b]{2}{*}{ Total } \\
\hline & & Sim & Não & \\
\hline $\begin{array}{l}\text { atendeu/excedeu } \\
\text { não atendeu/atendeu parcialmente } \\
\text { Total }\end{array}$ & $\begin{array}{l}\text { frequência } \\
\% \\
\text { frequência } \\
\% \\
\text { frequência } \\
\% \\
\end{array}$ & $\begin{array}{c}31 \\
50,8 \% \\
30 \\
49,2 \% \\
61 \\
100,0 \% \\
\end{array}$ & $\begin{array}{c}65 \\
74,7 \% \\
22 \\
25,3 \% \\
87 \\
100,0 \% \\
\end{array}$ & $\begin{array}{c}96 \\
64,9 \% \\
52 \\
35,1 \% \\
148 \\
100,0 \% \\
\end{array}$ \\
\hline
\end{tabular}

Fonte: autoria própria, com base em pesquisa para esta tese.

Tabela 25: Distribuição conjunta de justiça nos processos de seleção, avaliação, promoção e outros procedimentos relacionados não atendida/ parcialmente atendida e sentir-se lesado.

\begin{tabular}{|c|c|c|c|c|}
\hline \multirow{2}{*}{\multicolumn{2}{|c|}{$\begin{array}{l}\text { P6B.Justiça nos processos de seleção, avaliação, } \\
\text { promoção e outros procedimentos relacionados }\end{array}$}} & \multicolumn{2}{|c|}{$\begin{array}{l}\text { Você se sentiu lesado em } \\
\text { algum momento pela } \\
\text { organização? }\end{array}$} & \multirow[b]{2}{*}{ Total } \\
\hline & & Sim & Não & \\
\hline $\begin{array}{l}\text { atendeu/excedeu } \\
\text { não atendeu/atendeu parcialmente } \\
\text { Total }\end{array}$ & $\begin{array}{l}\text { frequência } \\
\% \\
\text { frequência } \\
\% \\
\text { frequência } \\
\% \\
\end{array}$ & $\begin{array}{c}28 \\
45,9 \% \\
33 \\
54,1 \% \\
61 \\
100,0 \% \\
\end{array}$ & $\begin{array}{c}63 \\
72,4 \% \\
24 \\
27,6 \% \\
87 \\
100,0 \% \\
\end{array}$ & $\begin{array}{c}91 \\
61,5 \% \\
57 \\
38,5 \% \\
148 \\
100,0 \% \\
\end{array}$ \\
\hline
\end{tabular}

Fonte: autoria própria, com base em pesquisa para esta tese.

Tabela 26: Distribuição conjunta de plano de carreira não atendida/ parcialmente atendida e sentir-se lesado.

\begin{tabular}{|ll|c|c|c|}
\hline \multirow{2}{*}{} & & \multicolumn{2}{|c|}{$\begin{array}{c}\text { Você se sentiu lesado em } \\
\text { algum momento pela } \\
\text { organização? }\end{array}$} & \\
\cline { 3 - 4 } P7B.Plano de carreira & & Sim & Não & Total \\
\hline atendeu/excedeu & frequência & 35 & 70 & 105 \\
& $\%$ & $57,4 \%$ & $80,5 \%$ & $70,9 \%$ \\
não atendeu/atendeu parcialmente & frequência & 26 & 17 & 43 \\
& $\%$ & $42,6 \%$ & $19,5 \%$ & $29,1 \%$ \\
Total & frequência & 61 & 87 & 148 \\
& $\%$ & $100,0 \%$ & $100,0 \%$ & $100,0 \%$ \\
\hline
\end{tabular}

Fonte: autoria própria, com base em pesquisa para esta tese. 
Tabela 27: Distribuição conjunta de ambiente de trabalho idôneo e seguro não atendido/ parcialmente atendido e sentir-se lesado.

\begin{tabular}{|ll|c|c|c|}
\hline & & \multicolumn{2}{|c|}{$\begin{array}{c}\text { Você se sentiu lesado em } \\
\text { algum momento pela } \\
\text { organização? }\end{array}$} & \\
\cline { 3 - 4 } P17B.Ambiente de trabalho idôneo e seguro & & Sim & Não & \multirow{2}{*}{ Total } \\
\hline atendeu/excedeu & frequência & 46 & 77 & 123 \\
& $\%$ & $75,4 \%$ & $88,5 \%$ & $83,1 \%$ \\
não atendeu/atendeu parcialmente & frequência & 15 & 10 & 25 \\
& $\%$ & $24,6 \%$ & $11,5 \%$ & $16,9 \%$ \\
Total & frequência & 61 & 87 & 148 \\
& $\%$ & $100,0 \%$ & $100,0 \%$ & $100,0 \%$ \\
\hline
\end{tabular}

Fonte: autoria própria, com base em pesquisa para esta tese.

Tabela 28: Distribuição conjunta de justiça na aplicação das regras e disciplinas da organização não atendida/ parcialmente atendida e sentir-se lesado.

\begin{tabular}{|ll|c|c|c|}
\hline & & \multicolumn{2}{|l|}{$\begin{array}{c}\text { Você se sentiu lesado em } \\
\text { algum momento pela } \\
\text { organização? }\end{array}$} & \\
\cline { 3 - 4 } & & & & \\
P18B.Justiça na aplicação das regras e & & Sim & Não & Total \\
\hline disciplinas da organização & & 33 & 68 & 101 \\
& & $54,1 \%$ & $78,2 \%$ & $68,2 \%$ \\
natendeu/excedeu & frequência & 28 & 19 & 47 \\
não atendeu/atendeu parcialmente & frequência & $45,9 \%$ & $21,8 \%$ & $31,8 \%$ \\
Total & $\%$ & 61 & 87 & 148 \\
& frequência & $100,0 \%$ & $100,0 \%$ & $100,0 \%$ \\
\hline
\end{tabular}

Fonte: autoria própria, com base em pesquisa para esta tese.

Tabela 29: Distribuição conjunta de pacote de benefícios atrativos não atendida/ parcialmente atendida e sentir-se lesado.

\begin{tabular}{|ll|c|c|c|}
\hline & & \multicolumn{2}{|c|}{$\begin{array}{c}\text { Você se sentiu lesado em } \\
\text { algum momento pela } \\
\text { organização? }\end{array}$} & \\
\cline { 3 - 4 } P19B.Pacote de benefícios atrativos & & Sim & Não & Total \\
\hline atendeu/excedeu & frequência & 38 & 68 & 106 \\
& $\%$ & $62,3 \%$ & $78,2 \%$ & $71,6 \%$ \\
não atendeu/atendeu parcialmente & frequência & 23 & 19 & 42 \\
& $\%$ & $37,7 \%$ & $21,8 \%$ & $28,4 \%$ \\
Total & frequência & 61 & 87 & 148 \\
& $\%$ & $100,0 \%$ & $100,0 \%$ & $100,0 \%$ \\
\hline
\end{tabular}

Fonte: autoria própria, com base em pesquisa para esta tese.

Percebe-se, em todas estas tabelas (22 a 29), que o grupo que se sentiu lesado tem maior proporção de respondentes cujas promessas não foram cumpridas (ou cumpridas parcialmente), do que o grupo que não se sentiu lesado.

Como pode ser analisado nas próximas duas tabelas, 30 e 31 , além do tipo de promessa, sentir-se lesado relaciona-se ao número de promessas não atendidas (ou parcialmente atendidas), indicado pela variável soma_promessas, conclusão que está de 
acordo com a prova não-paramétrica de Mann-Whitney (U Mann-Whitney $=1339$; z = $5,166, \mathrm{p}=0,000<0,05)$. Pela prova de Mann-Whitney, conclui-se que o número de promessas não atendidas (ou apenas parcialmente atendidas) é (estocasticamente) diferente entre o grupo lesado e não lesado.

Analiticamente, sentir-se lesado tem média e mediana de promessas não atendidas maior do que respondentes não lesados (5 e 3, respectivamente), o que permite concluir que para a amostra em questão, o não atendimento ou atendimento parcial das promessas indicadas nas tabelas 30 e 31 gera um sentimento de lesão, não apenas a percepção de ruptura.

A estatística não-paramétrica faz grande uso de postos. O posto de uma resposta é a sua posição relativa aos demais valores respondidos, quando os dados estão em ordem crescente. O posto das observações é uma forma de medir a posição relativa da observação, sem usar o valor observado diretamente.

A média de postos do grupo que se sentiu lesado, descritivamente, é maior do que o grupo que não se sentiu lesado $(96,1$ ante 59,4$)$, o que indica maior número de promessas não atendidas para o primeiro grupo (sentir-se lesado).

Tabela 30: Estatísticas da Prova de Mann-Whitney

\begin{tabular}{|lccc|}
\hline \multicolumn{2}{|c|}{$\begin{array}{c}\text { soma_promessas } \\
\text { Você se sentiu lesado } \\
\text { em algum momento pela }\end{array}$} & & \\
organização? & $\mathrm{N}$ & Média de postos & Soma de postos \\
Sim & 61 & 96,05 & 5859 \\
Não & 87 & 59,39 & 5167 \\
\hline
\end{tabular}

Fonte: autoria própria, com base em pesquisa para esta tese.

Tabela 31: Estatística descritiva da soma de promessas

\begin{tabular}{|lccc|}
\hline \multicolumn{4}{c|}{ soma_promessas } \\
Você se sentiu lesado & \multicolumn{3}{c|}{} \\
em algum momento & & \multicolumn{2}{c|}{ Desvio- } \\
pela organização? & Média & Mediana & padrão \\
Sim & 5,6 & 5 & 2,8 \\
Não & 3,3 & 3 & 2,3 \\
\hline
\end{tabular}

Fonte: autoria própria, com base em pesquisa para esta tese. 
Pode-se dizer, então, que o sentimento de lesão depende do tipo de promessa não atendida (ou parcialmente atendida) e/ou o número dessas promessas, de alguma forma, não satisfeitas. Mas no caso deste trabalho, não foi possível determinar o tipo de promessa que leva o indivíduo a sentir-se lesado, devido ao pequeno tamanho da amostra.

Apresentados os resultados relativos à seção II do questionário, segue a análise descritiva da seção III.

\subsubsection{Análise descritiva da seção III}

A seção III do questionário teve por objetivo identificar quais reações foram apresentadas por aqueles que na seção II demonstraram ter alguma reação emocional/afetiva, em uma escala de zero (total discordância) a 10 (absoluta concordância). Os resultados desta seção estão apresentados na tabela 32, a seguir.

Tabela 32: Estatística descritiva das reações frente a não satisfação da promessa.

\begin{tabular}{|c|c|c|c|c|c|c|c|c|}
\hline Reações & $\mathrm{N}$ & $\mathrm{N}$ & Média & Mediana & Percentil 25 & Percentil 75 & \begin{tabular}{|c|} 
Desvio- \\
padrão
\end{tabular} & $\begin{array}{c}\text { Coeficiente de } \\
\text { Variação }\end{array}$ \\
\hline & Válidos & sem resposta & & & & & & \\
\hline $\begin{array}{l}\text { Senti vontade de me vingar da organização e/ou das pessoas que a } \\
\text { representam. }\end{array}$ & 174 & 10 & 1,6 & 0 & 0 & 2 & 2,7 & $168 \%$ \\
\hline Senti uma queda no meu nível de energia & 174 & 10 & 5,1 & 5 & 2 & 8 & 3,5 & $69 \%$ \\
\hline Senti um descontentamento que dura até hoje. & 174 & 10 & 3,7 & 2 & 0 & 7 & 3,5 & $95 \%$ \\
\hline $\begin{array}{l}\text { Tive a oportunidade de retaliar uma pessoa (ou grupo de pessoas) e } \\
\text { assim o fiz. }\end{array}$ & 174 & 10 & 0,7 & 0 & 0 & 0 & 2,0 & $268 \%$ \\
\hline Senti desinteresse pelas coisas que me cercavam & 174 & 10 & 3,7 & 3 & 0 & 7 & 3,4 & $91 \%$ \\
\hline Passei a não acatar todas as ordens como forma de protesto & 174 & 10 & 1,5 & 0 & 0 & 2 & 2,5 & $170 \%$ \\
\hline Nasceu em mim um sentimento de aversão à organização & 174 & 10 & 2,3 & 0,5 & 0 & 5 & 3,2 & $139 \%$ \\
\hline Passei a sentir ansiedade na minha relação com a organização & 174 & 10 & 3,5 & 2 & 0 & 7 & 3,5 & $100 \%$ \\
\hline Senti raiva em relação à organização & 174 & 10 & 2,2 & 1 & 0 & 3 & 3,1 & $142 \%$ \\
\hline Senti que a organização foi desleal comigo & 174 & 10 & 2,7 & 1 & 0 & 5 & 3,5 & $128 \%$ \\
\hline Fui apunhalado pela costas & 174 & 10 & 1,6 & 0 & 0 & 1,25 & 3,0 & $183 \%$ \\
\hline
\end{tabular}

Fonte: autoria própria, com base em pesquisa para esta tese.

De acordo com a tabela 32, observa-se que 10 elementos não responderam a qualquer uma destas questões. Em geral, nota-se alto grau de discordância frente a qualquer uma das reações. Em ordem decrescente de nível de discordância, é possível a seguinte análise.

- Nota-se alto grau de discordância frente a "Tive a oportunidade de retaliar uma pessoa (ou um grupo de pessoas) e assim o fiz", com $80 \%$ de respondentes atribuindo pontuação zero ou 1;

- Com médias de 2,8 (mediana $=1)$ e 3,0 (mediana $=2)$ se apresentam as expressões como "Passei a não acatar todas as ordens como forma de protesto" 
e "Senti vontade de me vingar da organização e/ou pessoas que a representam", respectivamente;

- "Fui apunhalado pelas costas" e "Senti raiva em relação à organização" se apresentam com mediana igual a 3 e médias próximas de 4 (3,7 e 4,3, respectivamente);

- Os maiores indícios (relativamente) de concordância (mediana não inferior a 5) se referem a "Senti um descontentamento que dura até hoje"; "Senti desinteresse pelas coisas que me cercavam" , "Passei a sentir ansiedade na minha relação com a organização", "Senti uma queda no meu nível de energia", "Senti que a organização foi desleal comigo" e "Nasceu em mim um sentimento de aversão à organização”. A mesma análise pode ser verificada entre aqueles que tiveram pelo menos uma reação frente ao atendimento parcial ou não atendimento da promessa, com maior concordância em relação ao total da amostra. Veja Tabela 33, a seguir:

Tabela 33: Estatística descritiva das reações frente a não satisfação da promessa (somente para amostra que teve alguma reação)

\begin{tabular}{|c|c|c|c|c|c|c|c|c|}
\hline Reações & $\begin{array}{l}\text { tamanho da } \\
\text { amostra }\end{array}$ & $\begin{array}{l}\mathrm{N} \text { sem } \\
\text { respostas }\end{array}$ & Média & Mediana & $\begin{array}{l}\text { Percentil } \\
\quad 25\end{array}$ & $\begin{array}{l}\text { Percentil } \\
\quad 75\end{array}$ & $\begin{array}{l}\text { Desvio- } \\
\text { padrão }\end{array}$ & $\begin{array}{l}\text { Coeficiente } \\
\text { de Variação }\end{array}$ \\
\hline $\begin{array}{l}\text { Senti vontade de me vingar da organização e/ou } \\
\text { das pessoas que a representam. }\end{array}$ & 61 & 1 & 3,0 & 2 & 0 & 5 & 3,1 & $106 \%$ \\
\hline Senti uma queda no meu nível de energia & 61 & 1 & 7,4 & 8 & 6,5 & 10 & 2,7 & $37 \%$ \\
\hline $\begin{array}{l}\text { Senti um descontentamento que dura até hoje. } \\
\text { Tive a oportunidade de retaliar uma pessoa (ou }\end{array}$ & 61 & 1 & 6,1 & 7 & 3 & 8,5 & 3,3 & $54 \%$ \\
\hline grupo de pessoas) e assim o fiz. & 61 & 1 & 1,4 & 0 & 0 & 1 & 2,8 & $199 \%$ \\
\hline Senti desinteresse pelas coisas que me cercavam.) & 61 & 1 & 5,9 & 7 & 4 & 8 & 3,1 & $53 \%$ \\
\hline $\begin{array}{l}\text { Passei a não acatar todas as ordens como forma de } \\
\text { protesto.) }\end{array}$ & 61 & 1 & 2,8 & 1 & 0 & 5 & 3,2 & $115 \%$ \\
\hline $\begin{array}{l}\text { Nasceu em mim um sentimento de aversão à } \\
\text { organização.) }\end{array}$ & 61 & 1 & 4,3 & 5 & 1 & 7,5 & 3,6 & $85 \%$ \\
\hline $\begin{array}{l}\text { Passei a sentir ansiedade na minha relação com a } \\
\text { organização.) }\end{array}$ & 61 & 1 & 5,2 & 6 & 1 & 8 & 3,7 & $73 \%$ \\
\hline Senti raiva em relação à organização.) & 61 & 1 & 4,3 & 3 & 1 & 8 & 3,6 & $84 \%$ \\
\hline Senti que a organização foi desleal comigo.) & 61 & 1 & 5,9 & 7 & 3 & 9 & 3,3 & $55 \%$ \\
\hline Fui apunhalado pela costas.) & 61 & 1 & 3,7 & 3 & 0 & 7 & 3,7 & $98 \%$ \\
\hline
\end{tabular}

Fonte: autoria própria, com base em pesquisa para esta tese.

Ou seja, os maiores níveis de concordância se referem a expressões com efeito interior à pessoa, nenhum efeito externo. Efeito externo: "vingança", "retaliação", "fui apunhalado pelas costas"; e efeito interno: "falta de energia", "descontentamento", "desinteresse", e assim por diante.

Realizada análise para validação das expressões como um constructo para avaliar reações emocionais frente ao não cumprimento das promessas realizadas pela organização, 
obteve-se o coeficiente $\alpha$ - Cronbach de 0,938 (para total da amostra) e 0,911 para grupo que se sentiu lesado pela organização, considerando-se validadas todas variáveis avaliadas.

Tal coeficiente, se elevado, indicaria a unidimensionalidade do constructo, porém ao se conduzir uma análise fatorial para os 174 respondentes, apresentada a seguir, observa-se que as variáveis do constructo são explicadas por 2 fatores.

A análise fatorial teve por objetivo a exploração dos dados dos respondentes de modo a sumarizá-los em fatores.

Antes de se realizar a análise fatorial, foram elaboradas as análises do teste KaiserMeyer-Olkin $(\mathrm{KMO})$ e do teste de esfericidade de Bartlett (TEB; $\mathrm{p}<.05)$, para verificar se as estruturas dos dados seriam adequadas para se proceder uma análise fatorial. A medida KMO $=0,923$ e TEB $(1488,593 ; \mathrm{p}=0,000)$, indica que a solução fatorial é possível de ser aplicada aos dados.

Tabela 34: Comunalidades

Senti vontade de me vingar da organização e/ou das pessoas que a representam. Comunalidade

Senti uma queda no meu nível de energia 0,594 Senti um descontentamento que dura até hoje. Tive a oportunidade de retaliar uma pessoa (ou grupo de pessoas) e assim o fiz. 0,792 0,798

Senti desinteresse pelas coisas que me cercavam.

0,817

Passei a não acatar todas as ordens como forma de protesto. $\quad 0,632$

Nasceu em mim um sentimento de aversão à organização. $\quad 0,758$

Passei a sentir ansiedade na minha relação com a organização. $\quad 0,681$

$\begin{array}{lc}\text { Senti raiva em relação à organização. } & 0,756\end{array}$

$\begin{array}{lc}\text { Senti que a organização foi desleal comigo. } & 0,72\end{array}$

$\begin{array}{ll}\text { Fui apunhalado pela costas. } & 0,704\end{array}$

Fonte: autoria própria, com base em pesquisa para esta tese.

Apenas 2 fatores foram capazes de explicar 71\% da variação dos dados (critério: autovalor $>1$ ). O primeiro fator explica $62 \%$ da estrutura dos dados e o segundo fator explica $9 \%$, conforme é possível observar na tabela 35 . 
Tabela 35: Variância Explicada

\begin{tabular}{|cccc|}
\hline Fator & Auto-Valor & $\begin{array}{c}\% \text { de } \\
\text { variância } \\
\text { explicada }\end{array}$ & $\begin{array}{c}\% \text { de variância } \\
\text { explicada } \\
\text { acumulada }\end{array}$ \\
1 & 6,8 & 62,0 & 62,0 \\
2 & 1,0 & 9,5 & 71,4 \\
\hline
\end{tabular}

Fonte: autoria própria, com base em pesquisa para esta tese.

Promovendo-se a rotação ortogonal dos fatores (método varimax), obteve-se o seguinte resultado:

Tabela 36: Carga fatorial em relação ao fator 1

\begin{tabular}{|lcc|}
\hline Variáveis & Fator1 & Fator2 \\
Senti desinteresse pelas coisas que me cercavam. & 0,881 & \\
Senti um descontentamento que dura até hoje. & 0,867 & \\
Senti uma queda no meu nível de energia & 0,85 & \\
Passei a sentir ansiedade na minha relação com a & & \\
organização. & 0,754 & \\
Nasceu em mim um sentimento de aversão à organização. & 0,701 & \\
Senti raiva em relação à organização. & 0,634 & 0,595 \\
Senti que a organização foi desleal comigo. & 0,608 & 0,592 \\
\hline
\end{tabular}

Fonte: autoria própria, com base em pesquisa para esta tese.

Tabela 37: Carga fatorial em relação ao fator 2

\begin{tabular}{|ll|}
\hline Variáveis & Fator2 \\
& \\
Tive a oportunidade de retaliar uma pessoa (ou grupo de pessoas) e as & 0,777 \\
Fui apunhalado pela costas.) & 0,715 \\
Passei a não acatar todas as ordens como forma de protesto.) & 0,666 \\
Senti vontade de me vingar da organização e/ou das pessoas que a rep & 0,665 \\
\hline
\end{tabular}

Fonte: autoria própria, com base em pesquisa para esta tese.

De posse dos escores fatoriais, procedeu-se a análise de conglomerado (conglomerados) para os 174 respondentes, de modo a obter uma segmentação da amostra, objetivando definir dois grupos de respondentes: um grupo que sentiu qualquer violação de contrato com a empresa, e outro grupo de respondentes que não se sentiu violado.

A análise de conglomerados é uma técnica multivariada que utiliza algoritmos para agrupar respondentes homogêneos em relação a um conjunto de variáveis. Estas variáveis 
estão aqui definidas como escores fatoriais referentes às reações frente à ruptura de Contrato Psicológico.

A análise de conglomerados é uma técnica exploratória, cuja solução - definição do número de conglomerados, pertinência de cada elemento a um conglomerado - não é única. Realizaram-se vários caminhos alternativos na busca da melhor solução, a saber:

(A) método de conglomerado hierárquico, aliado ao método de conglomerado nãohierárquico, com indicação de centro dos conglomerados;

(B) método hierárquico;

(C) procedimento $k$-means (não-hierárquico) com indicação de 2 conglomerados.

Os métodos A e C tiveram uma alta concordância nas soluções (86\%), os dois métodos resultaram em soma (em relação aos dois fatores) de SQResidual muito próximas (A: 214,60 e C: 210,77), porém optou-se pela solução C, por possuir melhor interpretação dos resultados para os objetivos aqui pretendidos, com as seguintes estatísticas descritivas.

Distribuição dos conglomerados

- 71 respondentes alocados no conglomerado 1 (41\% da amostra respondente)

- 103 respondentes alocados no conglomerado 2 (59\% da amostra respondente).

Tabela 38: Estatística descritiva dos escores fatoriais

\begin{tabular}{|c|c|c|c|c|}
\hline & & & Média & $\begin{array}{l}\text { Desvio- } \\
\text { Padrão }\end{array}$ \\
\hline \multirow[t]{2}{*}{$\begin{array}{l}\text { Conglomerado } 1 \text { - } \\
\text { violação }\end{array}$} & REGR factor score & 1 -Fator reação interna & 0,99 & 0,65 \\
\hline & $\begin{array}{l}\text { REGR factor score } \\
\text { externa }\end{array}$ & 2 - Fator ação/reação & 0,35 & 1,40 \\
\hline \multirow[t]{2}{*}{$\begin{array}{l}\text { Conglomerado } 2 \\
\text { não violação }\end{array}$} & REGR factor score & 1 -Fator reação interna & $-0,68$ & 0,51 \\
\hline & $\begin{array}{l}\text { REGR factor score } \\
\text { externa }\end{array}$ & 2 - Fator ação/reação & $-0,24$ & 0,45 \\
\hline
\end{tabular}

Fonte: autoria própria, com base em pesquisa para esta tese.

Realizada a prova não-paramétrica de Kolmogorov-Smirnov, rejeitou-se a hipótese de distribuição normal dos escores fatoriais tanto para fator $1(\mathrm{z}=1,636 ; \mathrm{p}=0,009)$, como para fator $2(z=2,742 ; p=0,000)$. 
Portanto, para comparar os conglomerados quanto à média dos escores fatoriais, procedeu-se a prova não-paramétrica de Mann-Whitney, apresentada na tabela 39 a seguir.

Tabela 39: Estatísticas relativas à Prova de Mann-Whitney

\begin{tabular}{|lllccc|}
\hline \multirow{2}{*}{ REGR factor score } & 1 -Fator reação interna & Cluster & N & Média de postos & Soma de postos \\
& & cluster violação & 71 & 136,21 & 9671 \\
& & cluster não violação & 103 & 53,92 & 5554 \\
REGR factor score & 2 - Fator ação/reação externa & cluster violação & 71 & 100,25 & 7118 \\
& & cluster não violação & 103 & 78,71 & 8107 \\
& & & & \\
\hline
\end{tabular}

Fonte: autoria própria, com base em pesquisa para esta tese.

Conforme esperado pela análise de conglomerado (tabela 40 que segue), as diferenças entre os fatores foram significativas $(\mathrm{p}=0,000 \mathrm{e} \mathrm{p}=0,006$, para fator 1 e fator 2 , respectivamente).

Tabela 40: Estatística do teste para Prova de Mann-Whitney

\begin{tabular}{|c|c|c|}
\hline & $\begin{array}{l}\text { REGR factor score } 1 \text { - } \\
\text { Fator reação interna }\end{array}$ & $\begin{array}{l}\text { REGR factor score } 2 \text { - Fator } \\
\text { ação/reação externa }\end{array}$ \\
\hline Mann-Whitney U & 198 & 2751 \\
\hline$Z$ & $-10,597$ & $-2,775$ \\
\hline $\mathrm{p}$ & 0 & 0,006 \\
\hline
\end{tabular}

Fonte: autoria própria, com base em pesquisa para esta tese.

De forma descritiva, o conglomerado 1, denominado conglomerado violação, tem escores mais elevados (de reação) do que o conglomerado 2, denominado conglomerado nãoviolação. Ainda, pela prova de Mann-Whitney, comparando-se os conglomerados perante as variáveis originais (de reação), ambos são significativamente diferentes, qualquer que seja a variável (ver apêndice 5).

Descritivamente, o conglomerado violação tem escores mais elevados do que o conglomerado não-violação, qualquer que seja a reação.

Apresentados os resultados relativos à seção III do questionário, segue a análise descritiva da seção IV. 


\subsubsection{Análise descritiva da seção IV}

A seção IV teve por objetivo identificar o tipo de contrato estabelecido pelo respondente, ou seja, se o contrato é relacional ou transacional. Isto sugere a criação de uma variável que reflita e quantifique o conceito por meio de um conjunto de variáveis relacionadas ao tema.

Com base nas questões da seção IV, os respondentes avaliavam, mediante uma escala de zero (total discordância) a 10 (total concordância), seu comportamento frente às diversas situações no trabalho atual.

A concordância das seguintes expressões $1,2,3,6,9,10,11,12,14,16$ e 19, de acordo com a literatura existente, aponta para um contrato transacional, enquanto a concordância frente às expressões $4,5,7,13,15,17,18$ e 20 aponta para um contrato relacional.

Os resultados obtidos nesta seção estão apresentados na tabela 41, a seguir.

Tabela 41: Estatísticas descritivas das variáveis relacionadas a Contrato Psicológico

\begin{tabular}{|c|c|c|c|c|c|c|c|c|}
\hline & & & & Percentil & & Percentil & Desvio- & Coeficiente de \\
\hline Questão & Minimo & Maximo & Média & 25 & Mediana & 75 & padrão & variação \\
\hline $\begin{array}{l}\text { (1) Qualquer treinamento que eu participe deve estar exclusivamente associado ao } \\
\text { trabalho que realizo na organização. }\end{array}$ & 0 & 10 & 4,3 & 0 & 4 & 8 & 3,6 & $82 \%$ \\
\hline $\begin{array}{l}\text { (2) A minha relação com a organização se baseia em termos claros, objetivos e } \\
\text { explícitos, não gerando problemas de entendi/o entre as partes. }\end{array}$ & 0 & 10 & 6,7 & 5 & 7 & 9 & 2,7 & $40 \%$ \\
\hline (3) Minha estada nesta organização é por tempo limitado & 0 & 10 & 5,4 & 2 & 5 & 9 & 3,7 & $69 \%$ \\
\hline $\begin{array}{l}\text { (4) Para meu desenvolvimento profissional nesta empresa, o estabelecimento de } \\
\text { relações pessoais e afetivas contam muito. }\end{array}$ & 0 & 10 & 6,8 & 5 & 7 & 9 & 2,9 & $42 \%$ \\
\hline $\begin{array}{l}\text { (5) Na organização há espaço para as questões da minha vida pessoal, tais como } \\
\text { família e bem-estar. }\end{array}$ & 0 & 10 & 5,8 & 4 & 6 & 8 & 2,9 & $50 \%$ \\
\hline $\begin{array}{l}\text { (6) Meu comprometimento com a organização é limitado ao contrato de trabalho } \\
\text { estabelecido por nós. }\end{array}$ & 0 & 10 & 2,7 & 0 & 2 & 5 & 2,9 & $107 \%$ \\
\hline (7) As pessoas são parte importante do meu desenvolvimento nesta organização. & 0 & 10 & 7,8 & 7 & 8 & 10 & 2,4 & $31 \%$ \\
\hline $\begin{array}{l}\text { (9) Qualquer mudança nos termos acordados entre mim e organização devem ser } \\
\text { previamente negociados }\end{array}$ & 0 & 10 & 7,0 & 5 & 8 & 10 & 2,9 & $42 \%$ \\
\hline (10) A organização valoriza o uso dos meus conhecimentos e habilidades. & 0 & 10 & 7,0 & 6 & 8 & 9 & 2,6 & $37 \%$ \\
\hline $\begin{array}{l}\text { (11) Para mim, há uma relação direta entre minhas entregas profissionais e } \\
\text { remuneração. }\end{array}$ & 0 & 10 & 6,1 & 4 & 7 & 8 & 3,1 & $50 \%$ \\
\hline (12) Meu envolvimento com a organização é predominantemente profissional. & 0 & 10 & 6,7 & 5 & 7,5 & 9 & 2,8 & $42 \%$ \\
\hline $\begin{array}{l}\text { (13) Está claro que os termos de troca entre mim e organização emergem com o } \\
\text { tempo. }\end{array}$ & 0 & 10 & 5,8 & 5 & 6 & 8 & 2,6 & $45 \%$ \\
\hline $\begin{array}{l}\text { (14) Minha relação com a organização é fortemente regida pelo desenvolvimento } \\
\text { de minhas habilidades . }\end{array}$ & 0 & 10 & 6,6 & 5 & 7 & 9 & 2,7 & $40 \%$ \\
\hline $\begin{array}{l}\text { (15) meu comprometimento com a organização vai além daquilo que foi } \\
\text { formalmente acordado. }\end{array}$ & 0 & 10 & 8,0 & 7 & 8,5 & 10 & 2,3 & $29 \%$ \\
\hline $\begin{array}{l}\text { (16) Acredito que aspectos do dia-a-dia de trabalho que excedam aquilo que foi } \\
\text { acordado entre mim e organização devem ser negociados. }\end{array}$ & 0 & 10 & 5,6 & 3 & 6 & 8 & 2,9 & $51 \%$ \\
\hline $\begin{array}{l}\text { (17) As atividades a serem desempenhadas não se restringem ao formalmente } \\
\text { acordado }\end{array}$ & 0 & 10 & 7,7 & 7 & 8 & 10 & 2,4 & $32 \%$ \\
\hline $\begin{array}{l}\text { (18) A minha relação com a organização requer forte compromisso com meu } \\
\text { constante auto-desenvolvimento. }\end{array}$ & 0 & 10 & 7,6 & 6 & 8 & 10 & 2,3 & $30 \%$ \\
\hline $\begin{array}{l}\text { (19) A minha relação com a organização prevê grande envolvimento com o } \\
\text { trabalho. }\end{array}$ & 1 & 10 & 8,5 & 8 & 9 & 10 & 1,7 & $20 \%$ \\
\hline $\begin{array}{l}\text { (20) A minha relação com a organização prevê grande envolvimento com as } \\
\text { pessoas com as quais trabalho. }\end{array}$ & 0 & 10 & 8,1 & 7 & 9 & 10 & 2,1 & $26 \%$ \\
\hline
\end{tabular}

Fonte: autoria própria, com base em pesquisa para esta tese. 
Algumas expressões, apresentadas na tabela 41 e numeradas 7, 9, 15, 17, 18, 19 e 20 obtiveram alto percentual de elevada concordância. 50\% dos respondentes apontaram entre os escores 8 e 9 , e $25 \%$ dos respondentes avaliaram estas expressões com escore máximo (10 pontos) de concordância .

As expressões 2, 4, 12 e 14 apresentaram uma concordância ainda elevada, porém com mediana resultante de 7 ou 7,5 pontos da escala, e $25 \%$ dos respondentes atribuindo nota 9 ou 10 de concordância.

A expressão 11 não se diferencia muito do último grupo mencionado anteriormente, porém obteve mediana igual a 7 e $3^{\circ}$. Quartil (percentil 75) igual a 8 .

As expressões 1, 3, 5, 13 e 16 tiveram mediana próxima do ponto médio da escala (5), denotando um equilíbrio entre o número de pessoas concordantes e discordantes das expressões.

Apenas a expressão 6 teve uma estatística de medida central (média $=2,7$ e mediana $=$ 2), que indica, descritivamente, maior discordância frente às demais questões $(25 \%$ dos respondentes apontaram para o escore zero da escala - absoluta discordância). Também é esta expressão que obteve maior dispersão relativa de respostas (107\%).

As questões, em geral, obtiveram uma dispersão não baixa nas respostas, com coeficiente de variação próximo ou acima de 0,30 com exceção de apenas uma expressão, a 19 , que possui coeficiente de variação de $20 \%$.

Para validação das expressões como constructo de tipo de Contrato Psicológico, obteve-se o coeficiente $\alpha$-Cronbach, apresentado na tabela 42, a seguir:

Tabela 42: Alpha de Cronbach da seção IV

\begin{tabular}{|l|l|}
\hline Variáveis & $\alpha$-Cronbach \\
\hline Q1 à Q20 & 0,660 \\
\hline Q1 à Q,20, retirando Q6 & 0,693 \\
\hline Q1 à Q,20, retirando Q3 e Q6 & 0,733 \\
\hline Q1 à Q,20, retirando Q3,Q6 e Q16 & 0,751 \\
\hline
\end{tabular}

Fonte: autoria própria, com base em pesquisa para esta tese.

Ou seja, para a avaliação do conceito de tipo de contrato (relacional ou transacional) é pertinente o uso das expressões Q1 a Q20, retirando-se as expressões 3, 6 e 16. 
A elaboração do índice relacional (variável relacional) se deu pela média das variáveis q4, q5, q7, q13, q15, q17, q18 e q20, enquanto a elaboração do índice transacional (variável transacional) se deu pela média das variáveis q1, q2, q9, q10, q11, q12, q14 e q19.

O índice relacional_transacional é a diferença entre variável relacional e variável transacional.

Conforme é possível observar no histograma 1 a seguir, o índice relacional_transacional possui uma distribuição normal, premissa necessária para o teste das hipóteses.

Histograma 1: Distribuição do índice relacional_transacional
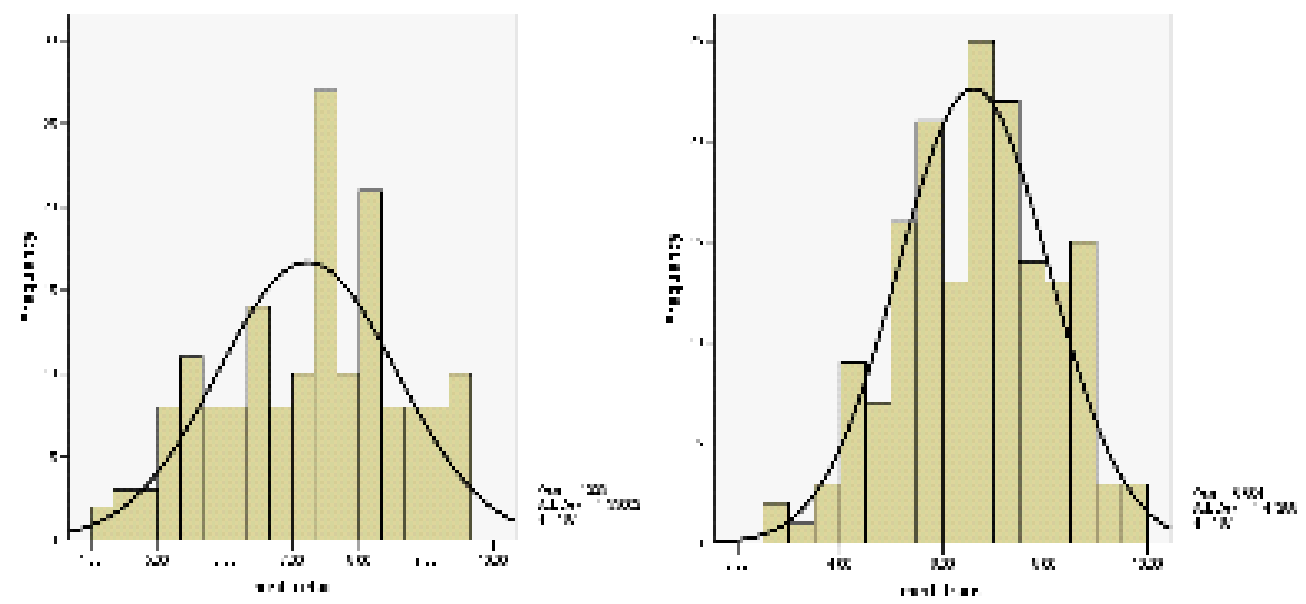

Fonte: autoria própria, com base em pesquisa para esta tese.

Apenas um respondente teve média igual a zero para a variável relacional, sendo considerado atípico e retirado da análise.

Conforme se observa na tabela 43, a seguir,o índice relacional_transacional tem média de 0,63 , mediana de 0,50 , e desvio padrão de 1,44 (coeficiente de variação $=231 \%$ ), o que indica uma alta dispersão relativa (em relação ao índice). Isto significa que a amostra deste estudo é passível de segmentação para Contrato Psicológico transacional e relacional. 
Tabela 43: Distribuição da variável índice relacional transacional

\begin{tabular}{|c|c|c|c|c|}
\hline & Freqüência & $\%$ & Percentual Válido & Percentual Cumulativo \\
\hline$-3,63$ & 1 & 0,5 & 0,6 & 0,6 \\
\hline-3 & 1 & 0,5 & 0,6 & 1,2 \\
\hline$-2,38$ & 1 & 0,5 & 0,6 & 1,8 \\
\hline$-1,88$ & 1 & 0,5 & 0,6 & 2,4 \\
\hline$-1,5$ & 3 & 1,6 & 1,8 & 4,2 \\
\hline$-1,38$ & 1 & 0,5 & 0,6 & 4,8 \\
\hline$-1,25$ & 8 & 4,4 & 4,8 & 9,6 \\
\hline$-1,13$ & 4 & 2,2 & 2,4 & 12 \\
\hline-1 & 7 & 3,8 & 4,2 & 16,2 \\
\hline$-0,88$ & 1 & 0,5 & 0,6 & 16,8 \\
\hline$-0,75$ & 3 & 1,6 & 1,8 & 18,6 \\
\hline$-0,63$ & 4 & 2,2 & 2,4 & 21 \\
\hline$-0,5$ & 8 & 4,4 & 4,8 & 25,7 \\
\hline$-0,38$ & 4 & 2,2 & 2,4 & 28,1 \\
\hline$-0,25$ & 6 & 3,3 & 3,6 & 31,7 \\
\hline$-0,13$ & 2 & 1,1 & 1,2 & 32,9 \\
\hline 0 & 4 & 2,2 & 2,4 & 35,3 \\
\hline 0,13 & 4 & 2,2 & 2,4 & 37,7 \\
\hline 0,25 & 9 & 4,9 & 5,4 & 43,1 \\
\hline 0,38 & 7 & 3,8 & 4,2 & 47,3 \\
\hline 0,5 & 5 & 2,7 & 3 & 50,3 \\
\hline 0,63 & 6 & 3,3 & 3,6 & 53,9 \\
\hline 0,75 & 6 & 3,3 & 3,6 & 57,5 \\
\hline 0,88 & 6 & 3,3 & 3,6 & 61,1 \\
\hline 1 & 3 & 1,6 & 1,8 & 62,9 \\
\hline 1,13 & 9 & 4,9 & 5,4 & 68,3 \\
\hline 1,25 & 3 & 1,6 & 1,8 & 70,1 \\
\hline 1,38 & 4 & 2,2 & 2,4 & 72,5 \\
\hline 1,5 & 3 & 1,6 & 1,8 & 74,3 \\
\hline 1,63 & 5 & 2,7 & 3 & 77,2 \\
\hline 1,75 & 2 & 1,1 & 1,2 & 78,4 \\
\hline 1,88 & 5 & 2,7 & 3 & 81,4 \\
\hline 2,13 & 6 & 3,3 & 3,6 & 85 \\
\hline 2,25 & 1 & 0,5 & 0,6 & 85,6 \\
\hline 2,38 & 8 & 4,4 & 4,8 & 90,4 \\
\hline 2,5 & 3 & 1,6 & 1,8 & 92,2 \\
\hline 2,63 & 2 & 1,1 & 1,2 & 93,4 \\
\hline 2,75 & 1 & 0,5 & 0,6 & 94 \\
\hline 2,88 & 1 & 0,5 & 0,6 & 94,6 \\
\hline 3,13 & 2 & 1,1 & 1,2 & 95,8 \\
\hline 3,25 & 1 & 0,5 & 0,6 & 96,4 \\
\hline 3,38 & 1 & 0,5 & 0,6 & 97 \\
\hline 3,75 & 1 & 0,5 & 0,6 & 97,6 \\
\hline 4 & 1 & 0,5 & 0,6 & 98,2 \\
\hline 4,13 & 2 & 1,1 & 1,2 & 99,4 \\
\hline 5 & 1 & 0,5 & 0,6 & 100 \\
\hline Total & 167 & 91,3 & 100 & \\
\hline Sistema & 16 & 8,7 & & \\
\hline & 183 & 100 & & \\
\hline
\end{tabular}

Note que quatro respondentes estão equilibrados quanto ao tipo de contrato relacional ou transacional (diferença de médias igual a zero). Outros $15 \%$ estão próximos deste equilíbrio (entre -1,96 erros - padrão e $+1,96$ erros - padrão). 


\section{$5.3 \mathrm{O}$ teste das hipóteses}

Para dividir a amostra por respondentes com características relacionais ou transacionais, considerou-se:

- caso o índice relacional transacional fosse positivo, o respondente seria considerado relacional e

- caso o índice relacional_transacional fosse negativo, o respondente seria considerado transacional.

Desta caracterização resultou que, entre os respondentes, $66 \%$ são relacionais e $34 \%$ são transacionais, conforme tabela 44 a seguir.

Tabela 44: Distribuição de Contratos Relacionais e Transacionais estabelecidos pelos respondentes.

\begin{tabular}{|llrrrr|}
\hline \multicolumn{1}{|l}{ novo_contrato1 } & \multicolumn{4}{c}{ Percentual } \\
& & Frequência & Percentual & Válido \\
Válido & Relacional & 108 & 59 & 66,3 \\
& Transacional & 55 & 30,1 & 33,7 \\
& Total & 163 & 89,1 & 100 \\
Missing & System & 20 & 10,9 & \\
Total & & 183 & 100 & \\
\hline
\end{tabular}

Fonte: autoria própria, com base em pesquisa para esta tese.

Será considerada, também, para a análise das respostas do questionário, a premissa de que mesmo o respondente indicando atendimento do indicador do Contrato Psicológico, ele possa apresentar alguma reação. O objetivo desta premissa é identificar aquelas pessoas que dizem que foram atendidas, mas, ainda sim, apresentam reação.

A seguir, serão apresentados os testes das hipóteses, considerando a estrutura de tópicos utilizada na seção 4.1, As hipóteses do capítulo Procedimentos Metodológicos. Para tanto, serão testadas, inicialmente, as hipóteses relativas aos tipos gerais de atitude e o Contrato Psicológico. Em seguida, serão testadas as hipóteses relativas às funções psíquicas e o Contrato Psicológico e, por último, as hipóteses relativas à função superior e a violação do Contrato Psicológico. Para facilitar o entendimento do leitor, o quadro a seguir explicita a 
relação entre as hipóteses gerais e específicas e as de nulidade, a partir das numerações criadas para as mesmas.

\begin{tabular}{|c|c|c|}
\hline Hipótese de Nulidade 1 & $\begin{array}{l}\text { Hipótese Ge } \\
\text { Hipótese } 1 \mathrm{a} \\
\text { Hipótese } 1 \mathrm{~b}\end{array}$ & \\
\hline Hipótese de Nulidade $2 \mathrm{a}, \mathrm{b}$ & $\begin{array}{l}\text { Hipótese } 2 \mathrm{a} \\
\text { Hipótese } 2 \mathrm{~b}\end{array}$ & \multirow[t]{2}{*}{ Hipótese Geral 2} \\
\hline Hipótese de Nulidade 2c,d & $\begin{array}{l}\text { Hipótese 2c } \\
\text { Hipótese 2d }\end{array}$ & \\
\hline Hipótese de Nulidade 3 & \multicolumn{2}{|l|}{ Hipótese 3} \\
\hline Hipótese de Nulidade 4 & \multicolumn{2}{|l|}{ Hipótese 4} \\
\hline
\end{tabular}

Quadro 2: Síntese da relação entre hipótese de nulidade e hipóteses gerais e específicas. Fonte: autoria própria

\subsubsection{Os tipos gerais de atitude e o Contrato Psicológico}

Hipótese de Nulidade 1: O TIPO DE CONTRATO PSICOLÓGICO INDEPENDE DE A PESSOA SER EXTROVERTIDA OU INTROVERTIDA

Para testar a Hipótese Geral 1, bem como as Hipóteses 1a, 1b, apresentadas na seção 4.1.1 do capítulo Procedimentos Metodológicos, foi utilizada a Prova do Qui-Quadrado, que testa a independência entre 2 variáveis nominais.

Em relação ao teste da Hipótese Geral 1 - Tipos gerais de atitude estão associados à classificação do Contrato Psicológico (relacional ou transacional), os seguintes resultados foram obtidos:

Tabela 44: Distribuição conjunta entre Contrato Psicológico e tipos de atitude

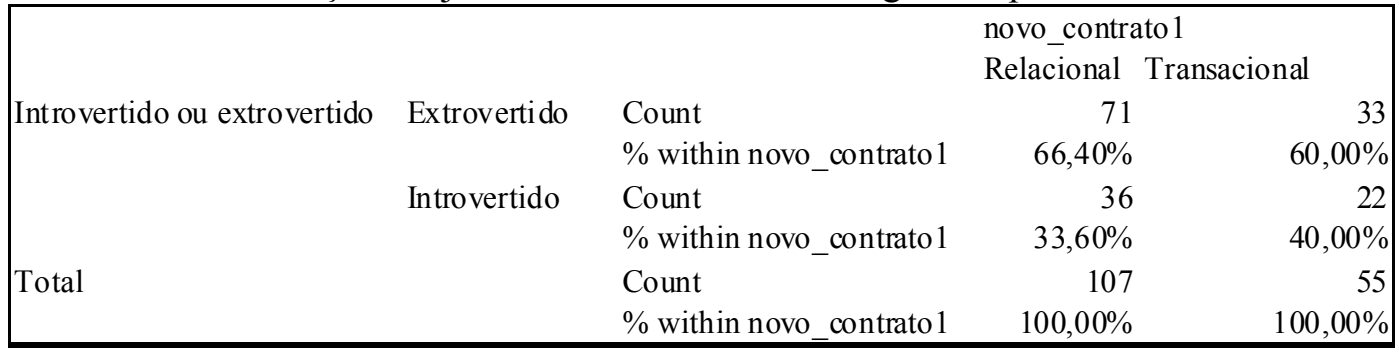

Fonte: autoria própria, com base em pesquisa para esta tese. 
Analisando-se a tabela 44, nota-se que o percentual de pessoas do tipo extrovertido com Contrato Psicológico relacional e transacional é muito próximo $(66,4 \%$ e 60,0\%, respectivamente), indicando que, provavelmente, não há distinção entre a formação de um tipo de Contrato Psicológico para extrovertidos e introvertidos.

Por meio da prova do Qui-Quadrado não foi possível apontar associação entre tipo de Contrato Psicológico e tipo geral de atitude (extroversão ou introversão), tendo em vista os resultados de $\chi^{2}=0,638 ; p=0,424>0,05$. Ou seja, ser extrovertido ou introvertido não se relaciona ao tipo de Contrato Psicológico estabelecido. Isto posto, o teste da Hipótese 1a Pessoas extrovertidas tendem a formar Contratos Psicológicos transacionais; e Hipótese $1 \mathrm{~b}$ Pessoas introvertidas tendem a formar Contratos Psicológicos relacionais não é confirmado.

\subsubsection{As funções psíquicas preferenciais e o Contrato Psicológico}

Hipótese de Nulidade 2a,b: A FUNÇÃO PSÍQUICA SENSAÇÃO OU INTUIÇÃO É INDEPENDENTE DO TIPO DE CONTRATO PSICOLÓGICO.

Para testar a Hipótese Geral 2, bem como as Hipóteses 2a, 2b, 2c e 2d, apresentadas na seção 4.1.2 do capítulo Procedimentos Metodológicos, foi utilizada a Prova do Qui-Quadrado.

Em relação ao teste da Hipótese 2a - Pessoas do tipo sensação tendem a formar Contratos Psicológicos transacionais; e Hipótese $2 \mathrm{~b}$ - Pessoas do tipo intuição tendem a formar Contratos Psicológicos relacionais, os seguintes resultados foram obtidos:

Tabela 45: Distribuição conjunta entre Contrato Psicológico e função psíquica irracional

\begin{tabular}{|lllrr|}
\hline & & & \multicolumn{2}{c|}{ novo_contratol } \\
& & & Relacional & Transacional \\
Sensação ou intuição & Sensação & Count & 64 & 38 \\
& & $\%$ within novo_contrato1 & $59,80 \%$ & $69,10 \%$ \\
& Intuição & Count & 43 & 17 \\
& & $\%$ within novo_contrato1 & $40,20 \%$ & $30,90 \%$ \\
Total & & Count & 107 & 55 \\
& & \% within novo_contrato1 & $100,00 \%$ & $100,00 \%$ \\
\hline
\end{tabular}

Fonte: autoria própria, com base em pesquisa para esta tese.

Nota-se que a diferença dos percentuais entre Contratos Psicológicos transacionais e relacionais de pessoas do tipo sensação é de, aproximadamente, dez pontos percentuais $(69,10 \%$ e $59,80 \%$, respectivamente). O mesmo ocorre para as pessoas do tipo intuição. 
Por meio da Prova do Qui-Quadrado, não foi possível apontar dependência entre função psíquica irracional (sensação ou intuição) e tipo de Contrato Psicológico, tendo em vista os resultados $\chi^{2}=1,341 ; \mathrm{p}=0,247>0,05$. Ou seja, ser sensação ou intuição não se relaciona ao tipo de Contrato Psicológico estabelecido.

Hipótese de Nulidade 2c,d: A FUNÇÃO PSÍQUICA PENSAMENTO OU SENTIMENTO É INDEPENDENTE DO TIPO DO CONTRATO PSICOLÓGICO.

Em relação ao teste da Hipótese 2c - Pessoas do tipo pensamento tendem a formar Contratos Psicológicos transacionais; e Hipótese $2 \mathrm{~d}$ - Pessoas do tipo sentimento tendem a formar Contratos Psicológicos relacionais, os seguintes resultados foram obtidos.

Tabela 46: Distribuição conjunta entre Contrato Psicológico e função psíquica racional

\begin{tabular}{|c|c|c|c|c|}
\hline \multirow{3}{*}{ Pensamento ou sentimento } & \multirow[b]{3}{*}{ Sentimento } & & \multicolumn{2}{|c|}{ novo contratol } \\
\hline & & & Relacional & Transacional \\
\hline & & Count & 52 & 16 \\
\hline & & \% within novo_contratol & $48,60 \%$ & $29,10 \%$ \\
\hline & Pensamento & Count & 55 & 39 \\
\hline & & $\%$ within novo_contrato1 & $51,40 \%$ & $70,90 \%$ \\
\hline Total & & Count & 107 & 55 \\
\hline & & $\%$ within novo_contratol & $100,00 \%$ & $100,00 \%$ \\
\hline
\end{tabular}

Fonte: autoria própria, com base em pesquisa para esta tese.

Analisando-se a tabela 46, verifica-se que o percentual de pessoas do tipo sentimento que estabelecem Contrato Psicológico relacional ou transacional diferencia-se consideravelmente $(48,60 \%$ e $29,1 \%$, respectivamente), indicando que, provavelmente, há distinção entre a formação de um tipo de Contrato Psicológico para as funções psíquicas racionais.

Por meio da prova do Qui-Quadrado, foi possível diferenciar as duas amostras (relacional e transacional), no que diz respeito ao percentual de sentimento ou pensamento, tendo em vista os resultados $\chi^{2}=5,676 ; p=0,017<0,05$. Ou seja, o fato do funcionário ser pensamento ou sentimento influencia o tipo do Contrato Psicológico em termos de relação ou transação. 


\subsubsection{A função superior e a violação do Contrato Psicológico}

De acordo com o quadro 3 a seguir, classificaram-se todos os respondentes da pesquisa como Função Superior Judicativa (sentimento ou pensamento) ou Perceptiva (sensação ou intuição).

\begin{tabular}{|c|c|c|c|c|}
\hline & ST & SF & NF & NT \\
\hline I - - J & ISTJ & ISFJ & INJ & INT] \\
\hline$I--P$ & ISIP & ISEPP & INEP & INI $^{\mathrm{P}}$ \\
\hline$E-P$ & ESIP & ESFP & ENFP & FNTP \\
\hline E--J & ESTJ & ESFJ & ENEJ & ENLJ \\
\hline
\end{tabular}

Quadro 3: Possibilidades de Função Superior

Fonte: Myers e Myers, 1997, p. 38.

Assim sendo, foram testadas as seguintes hipóteses de nulidade.

Hipótese de Nulidade 3: A FUNÇÃO JUDICATIVA/ PERCEPTIVA É INDEPENDENTE DA PERCEPÇÃO DE RUPTURA.

Para testar a Hipótese 3 - Pessoas com Função Superior Perceptiva (sensação ou intuição) tendem a apresentar ruptura do Contrato Psicológico, foi utilizado o teste estatístico Qui-Quadrado.

Primeiramente, efetuou-se a distribuição conjunta entre os resultados da questão "Você se sentiu lesado em algum momento pela organização?" e as variáveis relativas à Função Superior (Judicativa e Perceptiva), com o objetivo de analisar suas freqüências. Os resultados obtidos estão expressos na tabela 47 a seguir. 
Tabela 47: Distribuição conjunta entre sentir-se lesado e Função Superior Judicativa/Perceptiva

\begin{tabular}{|c|c|c|c|c|}
\hline \multicolumn{5}{|l|}{$\begin{array}{l}\text { Vocè se sentiu lesado em } \\
\text { algum momento pela }\end{array}$} \\
\hline $\operatorname{Sim}$ & Frequência & 27 & 34 & 61 \\
\hline & $\%$ & $38,6 \%$ & $44,2 \%$ & $41,5 \%$ \\
\hline Nã̃o & Frequêtncia & 43 & 43 & 86 \\
\hline & $\%$ & $61,4 \%$ & $55,8 \%$ & $58,5 \%$ \\
\hline Total & $\begin{array}{l}\text { Frequência } \\
\%\end{array}$ & $\begin{array}{c}70 \\
100,0 \%\end{array}$ & $\begin{array}{c}77 \\
100,0 \%\end{array}$ & $\begin{array}{c}147 \\
100,0 \%\end{array}$ \\
\hline
\end{tabular}

Fonte: autoria própria, com base em pesquisa para esta tese.

Conforme é possível observar, dentre as pessoas que se sentiram lesadas, 44,2\% possuem Função Superior Judicativa e 38,6\% Função Superior Perceptiva.

Em seguida, foi aplicado o teste do Qui-Quadrado para os resultados referentes à variável sentir-se lesado e às variáveis Função Superior Judicativa e Perceptiva. O resultado obtido foi: $\chi^{2}=0,471, p=0,493>0,05$. Deste modo, não foi possível rejeitar a independência entre sentir-se lesado e a função superior perceptiva ou julgadora, ao nível de significância de 5\%. Ou seja, não foi possível apontar associação entre estas variáveis.

Frente aos resultados expostos até o momento, questionou-se a possibilidade dos respondentes entenderem a violação do Contrato Psicológico e o sentimento de lesão como variáveis de significados próximos. Testou-se, então, a Hipótese: A existência de violação não está relacionada à existência de lesão.

Promoveu-se a análise das respostas daqueles que se sentiram lesados e suas reações. A tabela 48 a seguir apresenta os resultados obtidos.

Tabela 48: Relação sentir-se lesado e reação emocional/afetiva

\begin{tabular}{|c|c|c|c|c|}
\hline \multirow[b]{2}{*}{ Reação } & & \multicolumn{2}{|c|}{$\begin{array}{l}\text { Você se sentiu } \\
\text { lesado em algum } \\
\text { momento pela } \\
\text { organização? }\end{array}$} & \multirow[t]{2}{*}{ Total } \\
\hline & & Sim & Não & \\
\hline \multirow[t]{2}{*}{ Sim } & Freqüência & 55 & 61 & 116 \\
\hline & $\%$ & $90,20 \%$ & $70,10 \%$ & $78,40 \%$ \\
\hline \multirow[t]{2}{*}{ Não } & Freqüência & 6 & 26 & 32 \\
\hline & $\%$ & $9,80 \%$ & $29,90 \%$ & $21,60 \%$ \\
\hline \multirow[t]{2}{*}{ Total } & Freqüência & 61 & 87 & 148 \\
\hline & $\%$ & $100,00 \%$ & $100,00 \%$ & $100,00 \%$ \\
\hline
\end{tabular}

Fonte: autoria própria, com base em pesquisa para esta tese. 
A tabela 48 demonstra que $70,1 \%$ dos que responderam que não se sentiram lesados pela organização tiveram algum tipo de reação emocional ou afetiva intensa. Por outro lado, $9,8 \%$ dos que se sentiram lesados, não tiveram qualquer tipo de reação deste tipo. Conclui-se que estas duas variáveis - sentir-se lesado e violação do Contrato Psicológico - sejam dependentes $\left(\chi^{2}=8,505 ; \mathrm{p}=0,004\right)$, pois há maior porcentagem de respondentes com alguma reação emocional/ afetiva entre o grupo que se sentiu lesado pela organização $(90,2 \%)$ do que no grupo que não se sentiu lesado (70,1\%). Deste modo, é possível dizer que se sentir lesado está associado a alguma reação por parte dos respondentes desta amostra.

Diante do exposto, com o objetivo de verificar se violação relaciona-se com sentimento de lesão, testou-se a seguinte Hipótese: conglomerado (violação e não violação) é independente do sentimento de lesão. Para tanto, procedeu-se o teste estatístico da Prova do Qui-Quadrado, cujos resultados seguem na Tabela 49.

Tabela 49: Resultados da Prova do Qui-Quadrado entre conglomerado violação e nãoviolação e sentir-se lesado.

\begin{tabular}{|c|c|c|c|c|}
\hline \multirow[b]{3}{*}{$\begin{array}{l}\text { Congiomerado } \\
\text { violaçäa }\end{array}$} & \multirow[b]{3}{*}{$\begin{array}{l}\text { Frequência } \\
\text { \% Você se sentiu lesado em algumn momento pela organtậăăo }\end{array}$} & \multicolumn{3}{|c|}{$\begin{array}{l}\text { Tocé se sentil lesado em } \\
\text { algum momento pela } \\
\text { orgarizacta }\end{array}$} \\
\hline & & $\operatorname{Sim}$ & \multicolumn{2}{|l|}{ Häo } \\
\hline & & $\begin{array}{l}46 \\
75 \%\end{array}$ & $\begin{array}{c}22 \\
26 \%\end{array}$ & $\begin{array}{c}68 \\
46 \%\end{array}$ \\
\hline & $\%$ Total & $31 \%$ & $15 \%$ & $46 \%$ \\
\hline Congomerado & Frequância & 15 & 64 & 79 \\
\hline | & 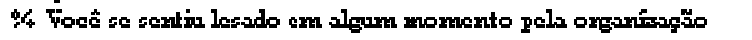 & $25 \%$ & $74 \%$ & $54 \%$ \\
\hline & $\%$ Total & $10 \%$ & $44 \%$ & $54 \%$ \\
\hline Total & Frequência & 61 & 86 & 147 \\
\hline & $\begin{array}{l}\text { \%wrthin Wocé se sentil lesado em algum morrento pela srgafizac } \\
\% \text { Total }\end{array}$ & $\begin{aligned} 100 \% \\
42 \%\end{aligned}$ & $100 \%$ & $\begin{array}{l}100 \% \\
100 \%\end{array}$ \\
\hline
\end{tabular}

Fonte: autoria própria, com base em pesquisa para esta tese.

O resultado do teste Qui-Quadrado para a relação sentir-se lesado e conglomerado violação e não violação foi: $\chi^{2}=35,642 ; p=0,000<0.05$. Com base nos resultados obtidos pela tabela 49 e Qui-Quadrado, pode-se concluir que:

- $75 \%$ dos que se sentiram lesados pertencem ao conglomerado violação;

- $74 \%$ do que não se sentiram lesados pela organização pertencem ao conglomerado não violação; 
- sentir-se lesado pela organização (ou percepção de ruptura) e alocação nos conglomerados têm $75 \%$ de coincidência ( $31 \%$ mais $44 \%$ apontados na tabela 49 anterior), o que talvez indique uma semelhança entre sentir-se lesado e ter sentido uma violação.

Frente aos resultados expostos, testou-se a seguinte Hipótese: A existência de violação não está relacionada ao atendimento de promessa (individualmente, para cada tipo de promessa).

Testando a associação entre conglomerado violação/ não violação e não atendimento ou atendimento parcial dos indicadores dos Contratos Psicológicos, tem-se:

Tabela 50: Níveis descritivos da Prova Qui-Quadrado / Fischer

\begin{tabular}{|l|c|c|}
\hline Indicador do Contrato Psicológico & $\chi^{2}$ & $\mathrm{p}$ \\
\hline P1B. Oportunidade de promoção & 17,063 & $0,000\left(^{*}\right)$ \\
\hline $\begin{array}{l}\text { P2B. Remuneração equivalente ao mercado e na } \\
\text { organização }\end{array}$ & 12,605 & $0,000\left(^{*}\right)$ \\
\hline P3B. Remuneração acima do mercado & & $0,475($ Fisher) \\
\hline P4B. Pagamento associado à alta performance & 19,978 & $0,000\left(^{*}\right)$ \\
\hline $\begin{array}{l}\text { P5B. Oportunidade de treinamento e desenvolvimento } \\
\text { adequados }\end{array}$ & 6,554 & $0,010\left(^{*}\right)$ \\
\hline $\begin{array}{l}\text { P6B. Justiça nos processos de seleção, avaliação, promoção } \\
\text { e outros procedimentos relacionados }\end{array}$ & 14,891 & $0,000\left(^{*}\right)$ \\
\hline P7B. Plano de carreira & 16,778 & $0,000\left(^{*}\right)$ \\
\hline P8B. Segurança no trabalho & 3,486 & 0,062 \\
\hline P9B. Suporte a problemas pessoais e/ou familiares & 1,325 & 0,250 \\
\hline $\begin{array}{l}\text { P10B. Tratamento humanizado (responsável e oferecendo } \\
\text { suporte ao empregado) }\end{array}$ & 2,669 & 0,102 \\
\hline P11B. Ambiente de intenso aprendizado & 0,804 & 0,370 \\
\hline $\begin{array}{l}\text { P12B. Exposição profissional dentro e/ou fora da } \\
\text { organização }\end{array}$ & 0,975 & 0,324 \\
\hline $\begin{array}{l}\text { P13B. Acesso (a clientes, poder, informações privilegiadas } \\
\text { entre outros) }\end{array}$ & 4,402 & $0,036\left(^{*}\right)$ \\
\hline P14B. Status social e profissional & 4,456 & $0,035\left(^{*}\right)$ \\
\hline P15B. Aceitação da diversidade & 4.424 & $0,039\left(^{*}\right)$ \\
\hline $\begin{array}{l}\text { P16B. Reconhecimento por contribuições especiais e/ou } \\
\text { inovadoras }\end{array}$ & 4,453 & $0,035\left(^{*}\right)$ \\
\hline P17B. Ambiente de trabalho idôneo e seguro & 9,392 & $0,002\left(^{*}\right)$ \\
\hline $\begin{array}{l}\text { P18B. Justiça na aplicação das regras e disciplinas da } \\
\text { organização }\end{array}$ & $0,035\left(^{*}\right)$ \\
\hline P19B. Pacote de benefícios atrativos & \\
\hline Font auna & $1,000($ Fisher \\
\hline
\end{tabular}

Fonte: autoria própria, com base em pesquisa para esta tese.

(*) Associação significativa ao nível de significância de 5\%.

(Fisher) mais que $25 \%$ das células com freqüência esperada menor que 5 , realizada portanto Prova de Fisher (e não Qui-Quadrado). 
Observa-se nos resultados apontados na Tabela 50 que os indicadores do Contrato Psicológico elencados a seguir, apresentam associação entre violação e não atendimento dos mesmos:

- $\quad$ oportunidade de promoção;

- remuneração equivalente ao mercado e na organização;

- pagamento associado à alta performance;

- oportunidade de treinamento e desenvolvimento adequados;

- justiça nos processos de seleção, avaliação, promoção e outros procedimentos relacionados;

- plano de carreira;

- $\quad$ status social e profissional;

- $\quad$ aceitação da diversidade;

- reconhecimento por contribuições especiais e/ou inovadoras;

- ambiente de trabalho idôneo e seguro;

- justiça na aplicação das regras e disciplinas da organização e

- pacote de benefícios atrativos

Ou seja, o não atendimento dos indicadores do Contrato Psicológico apresentados anteriormente acarreta em sentimento de violação. Explorando tais indicadores do Contrato Psicológico, têm-se os seguintes resultados:

Tabela 51: Distribuição conjunta de oportunidade de promoção não atendida/parcialmente atendida e conglomerado violação e não violação.

\begin{tabular}{|llccc|}
\hline P1B.Oportunidade de promoção & & conglomerado violação & conglomerado não violação & Total \\
atendeu/excedeu & Frequência & 38 & 85 & 123 \\
& \% conglomerado & $53,50 \%$ & $82,50 \%$ & $71 \%$ \\
não atendeu/atendeu parcialmente & Frequência & 33 & 18 & 51 \\
& \% conglomerado & $46,50 \%$ & $17,50 \%$ & $10 \%$ \\
Total & Frequência & 71 & 103 & 174 \\
& \%conglomerado & $100,00 \%$ & $100,00 \%$ & $100 \%$ \\
& & & & \\
\end{tabular}

Fonte: autoria própria, com base em pesquisa para esta tese. 
Tabela 52: Distribuição conjunta de remuneração equivalente ao mercado e na organização não atendida/parcialmente atendida e conglomerado violação e não violação.

\begin{tabular}{|llccc|}
\hline P2B.Remuneração equivalente ao mercado e & & conglomerado violação & conglomerado não violação & Total \\
na organização & Frequência & 48 & 92 & 140 \\
atendeu/excedeu & \% conglomerado & $67,60 \%$ & $89,30 \%$ & $81 \%$ \\
não atendeu/atendeu parcialmente & Frequência & 23 & 11 & 34 \\
& \% conglomerado & $32,40 \%$ & $10,70 \%$ & $10 \%$ \\
Total & Frequência & 71 & 103 & 174 \\
& \%conglomerado & $100,00 \%$ & $100 \%$ & $100 \%$ \\
\end{tabular}

Fonte: autoria própria, com base em pesquisa para esta tese.

Tabela 53: Distribuição conjunta de pagamento associado à alta performance não atendida/parcialmente atendida e conglomerado violação e não violação.

\begin{tabular}{|c|c|c|c|c|}
\hline $\begin{array}{l}\text { P4B.Pagamento associado à alta } \\
\text { performance }\end{array}$ & & conglomerado violação & conglomerado não violação & Total \\
\hline \multirow[t]{2}{*}{ atendeu/excedeu } & Frequência & 37 & 86 & 123 \\
\hline & $\%$ conglomerado & $52,10 \%$ & $83,50 \%$ & $71 \%$ \\
\hline \multirow[t]{2}{*}{ não atendeu/atendeu parcialmente } & Frequência & 34 & 17 & 51 \\
\hline & $\%$ conglomerado & $47,90 \%$ & $16,50 \%$ & $29 \%$ \\
\hline \multirow[t]{2}{*}{ Total } & Frequência & 71 & 103 & 174 \\
\hline & \%conglomerado & $100,00 \%$ & $100,00 \%$ & $100 \%$ \\
\hline
\end{tabular}

Fonte: autoria própria, com base em pesquisa para esta tese.

Tabela 54: Distribuição conjunta de oportunidade de treinamento e desenvolvimento adequados não atendida/parcialmente atendida e conglomerado violação e não violação.

\begin{tabular}{|c|c|c|c|c|}
\hline $\begin{array}{l}\text { P5B.Oportunidade de treinamento e } \\
\text { desenvolvimento adequados }\end{array}$ & & conglomerado violação & conglomerado não violação & Total \\
\hline \multirow[t]{2}{*}{ atendeu/excedeu } & Frequência & 52 & 91 & 143 \\
\hline & $\%$ conglomerado & $73,20 \%$ & $88,30 \%$ & $82 \%$ \\
\hline \multirow[t]{2}{*}{ não atendeu/atendeu parcialmente } & Frequência & 19 & 12 & 31 \\
\hline & $\%$ conglomerado & $26,80 \%$ & $11,70 \%$ & $18 \%$ \\
\hline \multirow[t]{2}{*}{ Total } & Frequência & 71 & 103 & 174 \\
\hline & \%conglomerado & $100,00 \%$ & $100,00 \%$ & $100 \%$ \\
\hline
\end{tabular}

Fonte: autoria própria, com base em pesquisa para esta tese.

Tabela 55: Distribuição conjunta de justiça nos processos de seleção (...) não atendida/parcialmente atendida e conglomerado violação e não violação.

\begin{tabular}{|llccc|}
\hline $\begin{array}{l}\text { P6B.Justiça nos processos de seleção, } \\
\text { avaliação, promoção e outros procedimentos } \\
\text { relacionados }\end{array}$ & & & & \\
atendeu/excedeu & Frequência & conglomerado violação & conglomerado não violação & Total \\
& \% conglomerado & 36 & 81 & 117 \\
não atendeu/atendeu parcialmente & Frequência & $50,70 \%$ & $78,60 \%$ & $67 \%$ \\
& \% conglomerado & $49,30 \%$ & 22 & 57 \\
Total & Frequência & 71 & $21,40 \%$ & 103 \\
& \%conglomerado & $100,00 \%$ & $100,00 \%$ & 174 \\
& & & $33 \%$ & $100 \%$ \\
\hline
\end{tabular}

Fonte: autoria própria, com base em pesquisa para esta tese. 
Tabela 56: Distribuição conjunta de plano de carreira não atendida/parcialmente atendida e conglomerado violação e não violação.

\begin{tabular}{|llccc|}
\hline P7B.Plano de carreira & & conglomerado violação & conglomerado não violação & Total \\
atendeu/excedeu & Frequência & 42 & 89 & 131 \\
& \% conglomerado & $59,20 \%$ & $86,40 \%$ & $75 \%$ \\
não atendeu/atendeu parcialmente & Frequência & 29 & 14 & 43 \\
& \% conglomerado & $40,80 \%$ & $13,60 \%$ & $25 \%$ \\
Total & Frequência & 71 & 103 & 174 \\
& \%conglomerado & $100,00 \%$ & $100,00 \%$ & $100 \%$ \\
& & & & \\
\end{tabular}

Fonte: autoria própria, com base em pesquisa para esta tese.

Tabela 57: Distribuição conjunta de status social e profissional não atendida/parcialmente atendida e conglomerado violação e não violação.

\begin{tabular}{|llccc|}
\hline P14B.Status social e profissional & & conglomerado violação & conglomerado não violação & Total \\
atendeu/excedeu & Frequência & 58 & 95 & 153 \\
& \% conglomerado & $81,70 \%$ & $92,20 \%$ & $88 \%$ \\
não atendeu/atendeu parcialmente & Frequência & 13 & 8 & 21 \\
& \% conglomerado & $18,30 \%$ & $7,80 \%$ & $12 \%$ \\
Total & Frequência & 71 & 103 & 174 \\
& \%conglomerado & $100,00 \%$ & $100,00 \%$ & $100 \%$ \\
& & & & \\
\end{tabular}

Fonte: autoria própria, com base em pesquisa para esta tese.

Tabela 58: Distribuição conjunta de aceitação da diversidade não atendida/parcialmente atendida e conglomerado violação e não violação.

\begin{tabular}{|llccc|}
\hline P15B.Aceitação da diversidade & conglomerado violação & conglomerado não violação & Total \\
atendeu/excedeu & Frequência & 60 & 97 & 157 \\
& \% conglomerado & $84,50 \%$ & $94,20 \%$ & $90 \%$ \\
não atendeu/atendeu parcialmente & Frequência & 11 & 6 & 17 \\
& \% conglomerado & $15,50 \%$ & $5,80 \%$ & $10 \%$ \\
Total & Frequência & 71 & 103 & 174 \\
& \%conglomerado & $100,00 \%$ & $100,00 \%$ & $100 \%$ \\
\hline
\end{tabular}

Fonte: autoria própria, com base em pesquisa para esta tese.

Tabela 59: Distribuição conjunta de reconhecimento por contribuições especiais e/ou inovadoras não atendida/parcialmente atendida e conglomerado violação e não violação.

\begin{tabular}{|llccc|}
\hline P16B.Reconhecimento por contribuições & & conglomerado violação & conglomerado não violação & Total \\
especiais e/ou inovadoras & Frequência & 45 & 80 & 125 \\
atendeu/excedeu & \% conglomerado & $63,40 \%$ & $77,70 \%$ & $72 \%$ \\
& Frequência & 26 & 23 & 49 \\
não atendeu/atendeu parcialmente & \% conglomerado & $36,60 \%$ & $22,30 \%$ & $28 \%$ \\
& Frequência & 71 & 103 & 174 \\
Total & \%conglomerado & $100,00 \%$ & $100,00 \%$ & $100 \%$ \\
& & & & \\
\hline
\end{tabular}

Fonte: autoria própria, com base em pesquisa para esta tese. 
Tabela 60: Distribuição conjunta de Ambiente de trabalho idôneo e seguro não atendida/parcialmente atendida e conglomerado violação e não violação.

\begin{tabular}{|llccc|}
\hline P17B.Ambiente de trabalho idôneo e seguro & & conglomerado violação & conglomerado não violação & Total \\
atendeu/excedeu & Frequência & 56 & 93 & 149 \\
& \% conglomerado & $78,90 \%$ & $90,30 \%$ & $86 \%$ \\
não atendeu/atendeu parcialmente & Frequência & 15 & 10 & 25 \\
& \% conglomerado & $21,10 \%$ & $9,70 \%$ & $14 \%$ \\
Total & Frequência & 71 & 103 & 174 \\
& \%conglomerado & $100,00 \%$ & $100,00 \%$ & $100 \%$ \\
\hline
\end{tabular}

Fonte: autoria própria, com base em pesquisa para esta tese.

Tabela 61: Distribuição conjunta de Justiça na aplicação das regras (...) não atendida/parcialmente atendida e conglomerado violação e não violação.

\begin{tabular}{|llccc|}
\hline P18B.Justiça na aplicação das regras e & & conglomerado violação & conglomerado não violação & Total \\
disciplinas da organização & Frequência & 43 & 84 & 127 \\
atendeu/excedeu & \% conglomerado & $60,60 \%$ & $81,60 \%$ & $73 \%$ \\
& Frequência & 28 & 19 & 47 \\
não atendeu/atendeu parcialmente & \% conglomerado & $39,40 \%$ & $18,40 \%$ & $27 \%$ \\
& Frequência & 71 & 103 & 174 \\
Total & \%conglomerado & $100,00 \%$ & $100,00 \%$ & $100 \%$ \\
& & & & \\
\hline
\end{tabular}

Fonte: autoria própria, com base em pesquisa para esta tese.

Tabela 62: Distribuição conjunta de pacote de benefícios atrativos não atendida/parcialmente atendida e conglomerado violação e não violação.

\begin{tabular}{|llccc|}
\hline P19B.Pacote de benefícios atrativos & conglomerado violação & conglomerado não violação & Total \\
atendeu/excedeu & Frequência & 48 & 84 & 132 \\
& \% conglomerado & $67,60 \%$ & $81,60 \%$ & $76 \%$ \\
não atendeu/atendeu parcialmente & Frequência & 23 & 19 & 42 \\
& \% conglomerado & $32,40 \%$ & $18,40 \%$ & $24 \%$ \\
Total & Frequência & 71 & 103 & 174 \\
& \%conglomerado & $100,00 \%$ & $100,00 \%$ & $100 \%$ \\
\hline
\end{tabular}

Fonte: autoria própria, com base em pesquisa para esta tese.

Descritivamente, a leitura das tabelas anteriores (51 a 62) permite entender que conglomerado violação tem maior percentual de não atendimento / atendimento parcial a estas promessas do que o conglomerado não violação.

É importante notar na Tabela 50 e nas tabelas de 51 a 60 , que grande parte dos indicadores do Contrato Psicológico apresenta associação entre reação e não atendimento; e que o conglomerado violação que possui maior percentual de não atendimento/atendimento parcial a estas promessas refere-se aos Contratos Psicológicos explícitos "Ambiente de Trabalho", "Oportunidade de treinamento e desenvolvimento", "Justiça na aplicação das regras...", "Pacote de Benefícios" e "Pagamento associado à alta performance". Tal resultado 
demonstra a importância dada, pelos respondentes, ao cumprimento da promessa explícita. Entretanto, os resultados que chamam atenção referem-se aos indicadores "Status social e profissional", "Oportunidade de Promoção" e "Plano de Carreira". O primeiro apresentou o $2^{\circ}$ menor percentual de percepção de promessa enquanto o segundo, o $7^{\circ}$, e o terceiro, o $8^{\circ}$. Mesmo assim, os respondentes apresentaram reação ao perceberem o não/parcial atendimento e, ainda, aqueles respondentes que fazem parte do conglomerado violação apresentaram maior percentual de não/parcial atendimento do que os respondentes do conglomerado não violação. Isto pode demonstrar que, mesmo não havendo (tanta) promessa por parte da organização, o atendimento destes indicadores é muito esperado. Ou ainda, que os respondentes, ao indicarem que mesmo havendo atendimento sentiram-se lesados, queiram expressar que outras promessas, contempladas ou não por esta pesquisa, não foram atendidas.

Hipótese de Nulidade 4: A FUNÇÃO JUDICATIVA/ PERCEPTIVA É INDEPENDENTE DA VIOLAÇÃO DO CONTRATO PSICOLÓGICO.

Para testar a Hipótese 4 - Pessoas com Função Superior Judicativa (pensamento ou sentimento) tendem a apresentar violação do Contrato Psicológico, procedeu-se o teste do Qui-Quadrado. Os seguintes resultados foram encontrados:

Tabela 63: Distribuição conjunta entre Função Superior Judicativa/ Perceptiva e Violação do Contrato Psicológico

\begin{tabular}{|llccc|}
\hline \multirow{3}{*}{ clustcr miolação } & Frequência & PERCEPTIVA & JUDICATIVA & Total \\
& $\%$ & 15 & 23 & 38 \\
Cluster nã̃o violação & Frequência & $17,9 \%$ & $25,8 \%$ & $22,0 \%$ \\
& $\%$ & 69 & 66 & 135 \\
Total & Frequência & $82,1 \%$ & $74,2 \%$ & $78,0 \%$ \\
& $\%$ & 84 & 89 & 173 \\
& $\%$ & $100,0 \%$ & $100,0 \%$ & $100,0 \%$ \\
\hline
\end{tabular}

Fonte: autoria própria, com base em pesquisa realizada para esta tese.

Observa-se na tabela 63 que do total das pessoas com função Superior Perceptiva, $17,9 \%$ pertencem ao conglomerado violação, enquanto do total das pessoas com Função Superior Judicativa, 25,8\% pertencem ao conglomerado violação. Tal resultado não indica uma diferença significativa entre eles, não permitindo concluir qualquer associação entre as variáveis. De acordo com a prova do Qui-Quadrado, $\chi^{2}=1,608, p=0,205>0,05$, não foi possível rejeitar a independência entre sentir-se lesado e a Função Superior Judicativa, ao 
nível de significância de 5\%. Ou seja, não foi possível apontar associação entre estas variáveis.

Os testes das hipóteses 3 e 4 apontam para a não associação entre as Funções Superiores Judicativas e Perceptivas e percepção e violação dos Contratos Psicológicos, respectivamente. Os resultados apresentados, na verdade, indicam que os respondentes que apresentaram violação à ruptura do Contrato Psicológico, o fizeram em função da explicitude e/ou importância do Contrato Psicológico. Os resultados expostos neste capítulo serão discutidos a seguir. 


\section{Discussão dos Resultados}

O capítulo 5 apresentou resultados que permitem tecer reflexões à luz de algumas teorias. Para tanto, este capítulo será organizado da seguinte forma: primeiramente, discutirse-ão os resultados descritivos da seção II do questionário e, em seguida, os resultados relativos às hipóteses de nulidade delineadas para esta tese, que representam as seções III e IV do questionário. É importante ressaltar que as inferências ou conclusões expostas não podem ser tomadas como base para a população.

\subsection{Discussão da análise descritiva da seção II}

A seção 5.2.1 Análise descritiva da seção II, referente à Coluna B do questionário, apresentou que os indicadores do Contrato Psicológico que obtiveram maior grau de não atendimento foram: "justiça nos processos de seleção, avaliação, promoção e outros procedimentos relacionados" $(8,5 \%)$; "pagamento associado à alta performance" $(8,5 \%)$; "oportunidade de promoção" (11,3\%); "reconhecimento por contribuições especiais e/ou inovadoras" (7,3\%); "justiça na aplicação das regras e disciplinas da organização" $(5,6 \%)$ e "plano de carreira" (13,6\%). Destes, "justiça nos processos de seleção, avaliação, promoção e outros procedimentos relacionados", "pagamento à alta performace" e "justiça na aplicação das regras e disciplinas da organização" apresentaram maior nível de promessa (entre 60 e $80 \%$ - ver gráfico 4$)$.

Isto provavelmente pode indicar que apesar das organizações brasileiras lançarem mão de discursos pró-justiça, eqüidade de tratamento entre seus funcionários, oportunidades de ascensão equânimes, elas ainda não conseguem promovê-los de fato, provavelmente, por conta de traços culturais brasileiros. Segundo os resultados da pesquisa de Chu (2006), as relações sociais funcionam como fator "determinador ou não da realização dos negócios no país, pois relacionamentos de confiança e intimidade valem por vezes mais do que a competência técnica (...)." (CHU, 2006, p. 91). Essas relações constituem o caminho para a resolução de problemas e obtenção de privilégios individuais ou coletivos dentro e fora das organizações, e são fundamentais para o desenvolvimento dos indivíduos e grupos nas organizações. Isto pode explicar, em parte, a dificuldade em se cumprir tais promessas no ambiente organizacional, pois são fatores que claramente podem depender das relações 
sociais e afetivas para se desenvolver. A aplicação da justiça nos processos de seleção, avaliação, promoção e outros procedimentos relacionados e na aplicação das regras e disciplinas da organização pode valer para alguns (aqueles que não fazem parte das relações sociais) e para outros não (aqueles que fazem parte das relações sociais e que obtêm privilégios delas). Ou seja, a regra pode não ser a mesma para todos. Algo semelhante pode ser concluído do pagamento associado à alta performance. Uma promessa deste tipo indica que os critérios de avaliação e pagamento da performance sejam claros e objetivos, e que a organização é justa ao aplicá-los. Entretanto, os resultados demonstram que este indicador apresenta $8,5 \%$ de não atendimento, o que pode sugerir que, em algumas organizações, a remuneração esteja atrelada a aspectos mais subjetivos, relativos às relações sociais e que haja uma pressão para que a remuneração não premie os eficientes.

Conway e Briner (2005) apontaram, em sua obra, a necessidade de verificar a influência que os aspectos culturais exercem na formação dos Contratos Psicológicos, bem como na ruptura e violação dos mesmos. Portanto, a discussão e sugestão apontadas anteriormente recomendam a realização de estudos de Contratos Psicológicos sob a ótica das diferenças culturais.

Outro resultado interessante, nesta mesma seção, é que o indicador "oportunidade de promoção", apesar de ter alto percentual cumulativo para "Não prometeu" e "Insinuou levemente" (49,8\%), apresenta baixo cumprimento (29,4\% dos respondentes admitem não terem sido atendidos ou parcialmente atendidos). O mesmo ocorre para o indicador "plano de carreira", que apresenta baixo percentual de promessa (tanto quanto oportunidade de promoção - 49,7\%) e, ainda assim, apresenta baixo cumprimento $(24,3 \%$ dos respondentes admitem não terem sido atendidos ou parcialmente atendidos). Este resultado indica que mesmo aquilo que não está sendo prometido pela organização, está sendo percebido como não cumprido. Este resultado, em uma primeira análise, poderia parecer estranho, afinal "Como alguém pode reclamar daquilo que não foi prometido?’.

Contrapondo-se as teorias de gestão de carreiras (ARTHUR, 1995; ARTHUR e ROUSSEAU, 1996; HALL e MOSS, HALL, 2002) - que frisam que a responsabilidade do desenvolvimento da carreira é do indivíduo e deve ser negociada com a organização - e os resultados obtidos, pode-se supor que muitos indivíduos ainda depositam nas organizações a responsabilidade por suas carreiras e seus desdobramentos, inclusive no que diz respeito à promoção. É como se a organização, automaticamente, fosse responsável pela ascensão profissional do indivíduo, dando-lhe todo o suporte necessário para que a carreira se 
desenvolvesse, sem que isso fosse de fato contratado. Isto pode indicar que os indivíduos desta amostra mantêm uma relação tradicional de carreira com as organizações para as quais trabalham e que, provavelmente, o conceito de carreira proteana (HALL e MOSS, 1998) e de carreira sem fronteiras (ARTHUR, 1995) pelas quais os indivíduos assumem as rédeas de suas carreiras, dentre outras características, não fazem parte de suas relações com as organizações.

Outra interpretação deste resultado: observando-se as tabelas de 22 a 29 (pp. 104 106), que incluem os indicadores "plano de carreira" e "oportunidade de promoção", percebese que sentir-se lesado não tem uma causa específica, ou seja, sentir-se lesado não está relacionado a um indicador do Contrato Psicológico específico. Tal conclusão é possível quando são comparadas as distribuições conjuntas dos indicadores do Contrato Psicológico não / parcialmente atendidos e sentir-se lesado. As distribuições, na sua totalidade, indicam apenas que o grupo que se sentiu lesado tem maior proporção de respondentes cujas promessas não foram cumpridas (ou cumpridas parcialmente) do que o grupo que não se sentiu lesado, independentemente do indicador. Isto pode apontar para a conclusão de que sentir-se lesado não esteja, necessariamente, associado aos indicadores do Contrato Psicológico apresentados aos respondentes por meio do questionário, e que este sentimento possa estar associado a outras promessas percebidas e não cumpridas. Portanto, sugere-se que pesquisas futuras verifiquem quais as causas que levam indivíduos a se sentirem lesados.

Ao final da seção 5.2.1., analisaram-se os resultados obtidos pela pergunta $\mathrm{W}$ da seção II. Conforme foi possível observar na Tabela 21 (p. 103), sentir-se lesado está relacionado à falta de cumprimento das promessas em relação à: "Oportunidade de promoção", "Remuneração equivalente ao mercado e na organização", "Pagamento associado à alta performance", "Plano de Carreira", "Justiça nos processos de seleção ...", “Ambiente de trabalho idôneo e seguro", "Justiça na aplicação de regras ...” e "Pacote de benefícios atrativos". Estes resultados demonstraram que tais indicadores do Contrato Psicológico são considerados importantes pela amostra respondente.

Estabelecendo-se um paralelo com a teoria Motivacional dos Dois Fatores (HERZBERG, 1987), todos os indicadores do Contrato Psicológico (exceto oportunidade de promoção) que mais se associam com o sentir-se lesado são os chamados higiênicos, ou seja, fatores que contribuem para a insatisfação no trabalho. $\mathrm{O}$ único indicador do Contrato Psicológico que pode ser considerado motivacional - fatores que contribuem para a satisfação com o trabalho - é oportunidade de promoção. A leitura que pode ser feita deste resultado é 
que o cumprimento de tais indicadores, ao não se apresentar adequado na relação de trabalho, gera insatisfação naqueles respondentes que disseram sentir-se lesados. Havendo associação entre sentir-se lesado e falta de cumprimento dos indicadores supracitados, pode-se supor que exista uma associação entre estar insatisfeito e sentir-se lesado, hipótese que deve ser objeto de estudos futuros.

Outro aspecto a ser observado, ao se compararem os resultados da tabela 19 e 21 (p. 101-103), é que o único fator motivacional associado a sentir-se lesado - oportunidade de promoção - apresenta o maior percentual de respondentes $(19,2 \%)$ que afirmam terem apresentado alguma reação emocional/afetiva, ao passo que os fatores higiênicos associados a sentir-se lesado apresentam menor percentual de reação emocional/afetiva, ainda que a diferença entre os percentuais do $1^{\circ}$ posto das reações para o $2^{\circ}$ seja pequena (de $3,4 \%$ ). Este resultado pode indicar a possibilidade de existência de associação entre fatores motivacionais e violação do Contrato Psicológico, algo a ser pesquisado futuramente. A seguir serão expostas as discussões relativas às hipóteses formuladas.

\subsection{Discussão dos resultados do teste das hipóteses}

A seção 5.3 tratou de testar as hipóteses formuladas para esta tese. Seguem as discussões relativas a cada uma das hipóteses de nulidade e as gerais e específicas.

A hipótese de nulidade 1: O TIPO DE CONTRATO PSICOLÓGICO INDEPENDE DE A PESSOA SER EXTROVERTIDA OU INTROVERTIDA foi aceita.

Analisando-se os resultados obtidos, conclui-se que a direção da libido não se relaciona ao tipo de Contrato Psicológico estabelecido (relacional ou transacional). Acreditase que a explicação para este resultado é que indivíduos extrovertidos e introvertidos apenas possuem diferentes preferências quanto à direção de suas atenções, e não preferências quanto ao tipo de relação a se estabelecer com a organização (objeto). Os extrovertidos preferem focar sua atenção e interesse naquilo que acontece no mundo exterior (pessoas, atividades, coisas - direção da libido para o objeto) enquanto os introvertidos focam sua atenção na impressão que o objeto causa neles, sujeito (idéias, emoções e impressões pessoais), e isso não se relaciona à preferência do tipo de contrato a ser estabelecido entre indivíduo e organização. Deste modo, a Hipótese geral 1 "O tipo de Contrato Psicológico (relacional ou 
transacional) estabelecido está associado ao tipo geral de atitude do indivíduo" não foi confirmada, assim como as específicas (Hipótese 1a e 1b).

A hipótese de nulidade 2a,b: A FUNÇÃO PSÍQUICA SENSAÇÃO OU INTUIÇÃO É INDEPENDENTE DO TIPO DE CONTRATO PSICOLÓGICO foi aceita.

Analisando-se os resultados obtidos, conclui-se que a forma como a pessoa captura a informação não se associa ao tipo de Contrato Psicológico. Acredita-se que a explicação para tal resultado ocorra porque a preferência pelo meio em que a pessoa obtém informações (por meio do cinco ou sexto sentido) não influencie o que é percebido, nem como o que foi percebido é processado. Em outras palavras, o Contrato Psicológico (percepção de promessa), sendo fruto da percepção da informação capturada, independe de como ela é capturada. Portanto, as Hipóteses $2 \mathrm{a}$ e $2 \mathrm{~b}$ foram rejeitadas.

A hipótese de nulidade 2c,d: A FUNÇÃO PSÍQUICA PENSAMENTO OU SENTIMENTO É INDEPENDENTE DO TIPO DO CONTRATO PSICOLÓGICO foi refutada.

A associação entre função psíquica racional e tipologia do contrato pode ser explicada da seguinte forma. O indivíduo, ao interagir com a organização, perceberá o estabelecimento de algumas promessas (termos/partes do Contrato Psicológico), que combinadas formarão um modelo mais amplo de contrato - composto de termos. Tal composto passará por um processo de avaliação do indivíduo, que deverá decidir: "Que tipo de contrato é esse?”, “Como esses termos se manifestarão na minha relação com a organização?". Neste momento, a função psíquica racional (pensamento e sentimento) exercerá influência sobre seu entendimento (tomada de decisão) a respeito da relação empregatícia, que culminará na indicação de uma tipologia (relacional ou transacional), especificando o tipo de relacionamento que vigora na relação. Indivíduos com função psíquica racional sentimento, organizarão e estruturarão o composto de termos de modo a tomar sua decisão de maneira pessoal e orientada para valores e emoções, de modo a entender sua relação empregatícia como relacional. O oposto ocorre para indivíduos que possuem função racional pensamento.

Assim sendo, a Hipótese geral 2 "O tipo de Contrato Psicológico (relacional ou transacional) estabelecido está associado à função psíquica preferencial do indivíduo" não pode ser confirmada, pois a associação existente depende do tipo de função psíquica em questão: a racional ou a irracional. Apenas as Hipóteses específicas 2c e 2d foram aceitas. 
A hipótese de nulidade 3: A FUNÇÃO JUDICATIVA/ PERCEPTIVA É INDEPENDENTE DA PERCEPÇÃO DE RUPTURA e a hipótese de nulidade 4: A FUNÇÃO JUDICATIVA/ PERCEPTIVA É INDEPENDENTE DA VIOLAÇÃO DO CONTRATO PSICOLÓGICO foram aceitas.

Apesar das pessoas com Função Superior Perceptiva inclinarem-se ao encontro de novas possibilidades, contornando situações, compreendendo as coisas e os fatos, muito mais do que os julgando, e pessoas com Funções Superiores Judicativas entenderem que a vida deva ser orientada e decidida e, quando decididas, sustentem seus esforços para colocar suas decisões em prática, tais Funções mostraram-se pouco atuantes frente aos dois momentos do rompimento do Contrato Psicológico: a percepção e a reação. Acredita-se que um possível motivo para os resultados encontrados esteja na limitação dos profissionais em reagir a uma ruptura em tempos de emprego escasso. Um dado que corrobora tal argumento é que os maiores níveis de concordância da seção III do questionário (relativo às reações frente à ruptura) se referem a expressões com efeito interno à pessoa, nenhum efeito externo. Efeito externo: "vingança", "retaliação", "fui apunhalado pelas costas"; e efeito interno: "falta de energia", "descontentamento", "desinteresse" e assim por diante.

Outra possível explicação para os resultados em questão é a própria amostra. Um público com maior nível educacional, mais maduro e, supostamente, mais preparado para lidar com suas questões emocionais, foi educado, ao longo dos anos de experiência profissional, para ter grande controle de suas emoções e instintos, evitando problemas de imagem no mercado. Ademais, o ambiente organizacional costuma reprimir demonstrações afetivas, principalmente as intensas. Isto pode ser evidenciado na própria definição teórica de ruptura e violação do Contrato Psicológico. A existência destes dois conceitos permite concluir que há a possibilidade daquele indivíduo que percebe a ruptura do Contrato Psicológico reagir ou não. Tais reações podem depender de inúmeras variáveis (ainda não pesquisadas), dentre as quais se acredita que o perfil do empregado possa exercer influência. Tal associação deve ser objeto de pesquisas futuras.

Os demais resultados apresentados no capítulo anterior (não relacionados diretamente com os objetivos desta tese), decorrentes de uma análise aprofundada dos dados obtidos na pesquisa, mostraram-se interessantes e diferentes das pesquisas nacionais e internacionais realizadas. Entretanto, pouco pode ser discutido sobre tais resultados, pois a teoria sobre o tema não oferece, ainda, insumos mais concretos para tal. Mas, com certeza, tais resultados servirão como um embrião para o delineamento de futuras pesquisas. 


\section{Conclusões}

Definiram-se como objetivos centrais desta pesquisa: 1) examinar se os tipos psicológicos exercem influência na captura e entendimento dos Contratos Psicológicos; 2) examinar se existe associação entre tipo psicológico e tipo de Contrato Psicológico; 3) examinar se existe associação entre o tipo psicológico e o comportamento do indivíduo quando este se depara com o não cumprimento do Contrato Psicológico. As hipóteses relativas a cada objetivo, bem como seus resultados estão expressos no quadro 4 que segue :

Quadro 4: Síntese das hipóteses, objetivos e resultados

\begin{tabular}{|l|l|l|}
\hline Hipóteses & Objetivo(s) & $\begin{array}{l}\text { Resultado } \\
\text { (aceita/rejeitada) }\end{array}$ \\
\hline $\begin{array}{l}\text { Hipótese geral 1: Tipos gerais de atitude estão } \\
\text { associados à classificação do Contrato } \\
\text { Psicológico (relacional ou transacional). }\end{array}$ & 1,2 & Rejeitada \\
\hline $\begin{array}{l}\text { Hipótese 1a: Pessoas extrovertidas tendem a } \\
\text { formar Contratos Psicológicos transacionais }\end{array}$ & 1,2 & Rejeitada \\
\hline $\begin{array}{l}\text { Hipótese 1b: Pessoas introvertidas tendem a } \\
\text { formar Contratos Psicológicos relacionais. }\end{array}$ & 1,2 & Rejeitada \\
\hline $\begin{array}{l}\text { Hipótese geral 2: As funções psíquicas } \\
\text { preferenciais estão associadas ao tipo de contrato } \\
\text { estabelecido pelo indivíduo. }\end{array}$ & 1,2 & Rejeitada \\
\hline $\begin{array}{l}\text { Hipótese 2a: Pessoas do tipo sensação tendem a } \\
\text { formar Contratos Psicológicos transacionais. }\end{array}$ & 1,2 & Rejeitada \\
\hline $\begin{array}{l}\text { Hipótese 2b: Pessoas do tipo intuição tendem a } \\
\text { formar Contratos Psicológicos relacionais. }\end{array}$ & 1,2 & Rejeitada \\
\hline $\begin{array}{l}\text { Hipótese 2c: Pessoas do tipo pensamento tendem } \\
\text { a formar Contratos Psicológicos transacionais. }\end{array}$ & $\underline{1,2}$ & $\underline{\text { Aceita }}$ \\
\hline $\begin{array}{l}\text { Hipótese 2d: Pessoas do tipo sentimento tendem a } \\
\text { formar Contratos Psicológicos relacionais. }\end{array}$ & $\underline{1,2}$ & Aceita \\
\hline $\begin{array}{l}\text { Hipótese 3: Pessoas com Função Superior } \\
\text { Perceptiva (sensação ou intuição) tendem a } \\
\text { apresentar ruptura do Contrato Psicológico. }\end{array}$ & 3 & Rejeitada \\
\hline $\begin{array}{l}\text { Hipótese 4: Pessoas com Função Superior } \\
\text { Judicativa (pensamento ou sentimento) tendem a } \\
\text { apresentar violação do Contrato Psicológico. }\end{array}$ & 3 & Rejeitada \\
\hline
\end{tabular}

Fonte: autoria própria

De todas as hipóteses formuladas, somente as Hipóteses $2 \mathrm{c}$ e $2 \mathrm{~d}$ - que verificam a associação entre funções psíquicas racionais (pensamento e sentimento) e o tipo de Contrato Psicológico estabelecido (relacional e transacional) - foram confirmadas. As demais foram 
rejeitadas. A partir destes resultados, algumas conclusões podem ser tecidas para a amostra em questão.

Primeiramente, a rejeição das hipóteses ( 2 a e 2 b) que contemplam a associação entre funções irracionais e o tipo de Contrato Psicológico estabelecido e a aceitação das hipóteses (2c e 2d) que tratam da associação entre funções racionais e tipo de contrato estabelecido indicam claramente que a formação do tipo do Contrato Psicológico não se relaciona com a apreensão do mesmo, mas com a reflexão a respeito daquilo que é capturado. Ou seja, a tipologia do contrato está relacionada a um processo de tomada de decisão daquilo que foi apreendido.

Apesar do resultado para as hipóteses $2 \mathrm{a}$ e $2 \mathrm{~b}$, é interessante notar a análise de discurso, realizada em pesquisa por CASADO (1998), dos indivíduos sensação e intuição. De um modo global, as pessoas sensação capturam, apreendem aquilo que é prático, real, concreto. Em suas falas, a visão prática das coisas e interesses econômicos está muito presente, como demonstram os dizeres: "O que interessa é o chequinho no final do mês", “com regras bem definidas para ascensão profissional” (CASADO, 1998, p. 132; 137). Estas colocações, dentre outras apresentadas na tese da autora, apontam para a "função do real" descrita por Jung (1991). Por outro lado, as pessoas intuição capturam aquilo que é abstrato e se focam nas possibilidades. Suas falas estão voltadas para os aspectos conceituais, as possibilidades, a discussão de questões mais globais, como demonstram as frases: "uma organização para o desenvolvimento das pessoas", "as diretrizes da empresa serão...". (CASADO, 1998, p. 136). Tais dizeres apontam para aspectos simbólicos, abstratos, comportamentos inovadores, novas possibilidades. (CASADO, 1998). Deste modo, é possível concluir que saber se a pessoa é intuição ou sensação ajuda as organizações na apresentação dos critérios dos Contratos Psicológicos, pois a forma como estes serão apresentados - de maneira mais explícita, concreta ou abstrata, implícita - facilitará o processo de captura das informações. Ou seja, a forma como a empresa se comunicará com indivíduos sensação ou intuição facilitará a compreensão dos termos do contrato que a organização deseja que sejam percebidos por eles.

De posse das informações capturadas, os indivíduos deverão tomar a decisão de como os termos do Contrato Psicológico se manifestarão na sua relação com a organização. Neste momento, as funções psíquicas racionais (pensamento e sentimento) agem, exercendo influência quanto ao tipo de Contrato Psicológico a ser formado (relacional ou transacional). Se a organização quiser atrair um talento, retê-lo ou mesmo fazê-lo perceber que o contrato 
está sendo cumprido, deverá lançar mão, para indivíduos com função pensamento, de comunicações mais explícitas, que ofereçam, em seu discurso, os princípios e a racionalidade envolvidos na relação de troca. Na mesma linha, as práticas de gestão de pessoas devem ser claras, com regras bem definidas, pois as decisões deste tipo de função são tomadas de forma racional e impessoal. Então, quanto mais explícitas, exatas, justas forem as condições da relação, mais a organização atenderá esta função, pois, de acordo com os resultados obtidos nesta tese, pessoas com função racional pensamento formam Contratos Psicológicos transacionais. Em outras palavras, pessoas que apresentam tal função estabelecem relações baseadas na troca, no estabelecimento de regras claras de trabalho, analisando-as sob critérios racionais, lógicos e pautados na justiça. Já para os indivíduos com função psíquica sentimento, as organizações deverão oferecer tratamento diferenciado quanto à comunicação e práticas de gestão de pessoas. A primeira deve ser mais implícita, carregando consigo um tom emocional, sentimental. O discurso deve considerar as possibilidades, o fazer pelo gostar e querer (CASADO, 1998), deve agradar, elogiar. De forma semelhante, as práticas de gestão de pessoas devem contemplar o grupo e as necessidades individuais em termos daquilo que gostam e querem, o sentimento e emoções das pessoas. Neste sentido, programas organizacionais que monitorem o clima, cuidem das pessoas, da família dos funcionários, que ofereçam planos de carreiras com muitas possibilidades agradam muito pessoas com esta função. Então, quanto mais afetivas forem as condições da relação, mais a organização atenderá esta função, pois de acordo com os resultados obtidos nesta tese, pessoas com função racional sentimento formam Contratos Psicológicos relacionais, ou seja, estabelecem relações baseadas na confiança mútua, na emoção, no afeto.Isto posto, acredita-se que rupturas ou violações do Contrato Psicológico ocorram em menor proporção, pois o entendimento sobre como tratar as funções psíquicas racionais contribuem para uma melhoria na percepção do atendimento dos Contratos Psicológicos..

As hipóteses que testavam associação entre Tipo Geral de Atitude (extroversão/ introversão) e tipo de Contrato Psicológico (transacional/ relacional), foram refutadas. Neste sentido, conclui-se que a direção da libido não se relaciona ao o tipo de Contrato Psicológico estabelecido (relacional ou transacional). Acredita-se que explicação para este resultado é que indivíduos extrovertidos e introvertidos apenas possuem diferentes preferências quanto à direção de suas atenções, e não preferências quanto ao tipo de relação a se estabelecer com a organização (objeto). Enquanto extrovertidos direcionam sua libido para o objeto, os introvertidos focam sua atenção na impressão que o objeto causa nele, sujeito (idéias, 
emoções e impressões pessoais), e isso não se relaciona à preferência do tipo de contrato a ser estabelecido entre indivíduo e organização

As hipóteses que testavam associação entre Funções Psíquicas Irracionais (sensação/ intuição) e tipo de Contrato Psicológico não foram confirmadas, permitindo concluir que a forma como a pessoa captura a informação não se associa ao tipo de Contrato Psicológico estabelecido. Acredita-se que a explicação para tal resultado ocorra porque a preferência pelo meio em que a pessoa obtém informações não influencie o que é percebido, nem como o que foi percebido é processado.

As hipóteses que testavam associação entre a Função Superior Perceptiva e ruptura do Contrato Psicológico e Função Superior Judicativa e violação do Contrato Psicológico também não foram confirmadas. Acredita-se que um possível motivo para os resultados encontrados esteja na dificuldade dos profissionais em reagirem a uma ruptura em tempos de emprego escasso e de extrema competitividade no mercado. Outra possível explicação para os resultados em questão é a própria amostra, que conforme mencionado na seção anterior, possui um perfil.específico Ademais, o ambiente organizacional costuma reprimir demonstrações afetivas, principalmente as intensas.

O teste das hipóteses, por si só, já trouxe contribuições muito relevantes para o desenvolvimento teórico do tema Contratos Psicológicos. Entretanto, a exploração dos resultados da amostra pesquisada permitiu um aprofundamento das análises realizadas. Algumas delas, embora não tenham sido inicialmente consideradas para o estudo, mostraramse interessantes, conforme os comentários que seguem.

De acordo com os resultados apresentados na seção 5.3.3 do capítulo 5, verificou-se associação entre sentir-se lesado e violação do Contrato Psicológico. Este resultado contribui para o conjunto de reações emocionais ou afetivas intensas levantadas pelas pesquisas de Menegon (2004) e Peyrat-Guillard (2008), como vingança, mágoa, preocupação, ansiedade entre outros (citados na íntegra no capítulo Fundamentação Teórica). Sentir-se lesado referese a sentir-se prejudicado, ofendido, molestado. Tal sentimento (interno ao indivíduo) passa a compreender mais uma das reações identificadas por pesquisas.

Ainda na seção e capítulos supracitados, observando-se o comportamento das respostas e alguns resultados, testou-se a associação entre cluster violação/ não violação com o tipo de promessa cujo descumprimento provocou alguma reação do respondente. O objetivo foi o de verificar a causa de a pessoa ter se sentido violada. Devido ao pequeno tamanho da 
amostra, só foi possível concluir pela associação entre grupo violação e reação ao não cumprimento da promessa relativa a plano de carreira. Este resultado, além de demonstrar que o indicador Plano de Carreira é muito importante para os respondentes da amostra, também traz uma reflexão importante. Segundo as análises realizadas, este indicador mostrou baixa percepção de promessa. Mesmo assim, os respondentes da amostra que não perceberam tal indicador como prometido, afirmaram não terem sido atendidos neste quesito e que o não atendimento gerou reação emocional ou afetiva neles. Isto pode indicar que tais respondentes desejam muito que as organizações onde trabalham ofereçam um plano de carreira, e que o não atendimento do mesmo gera neles reações emocionais ou afetivas diversas. Ou ainda, tal resultado pode indicar que os indivíduos entendam que oferecer um plano de carreira é uma condição obrigatória e básica na relação de trabalho.

O indicador "Status social e profissional" apresentou o $2^{\circ}$ menor percentual de percepção de promessa, enquanto "Oportunidade de promoção", o $7^{\circ}$. Entretanto, para ambos os indicadores, verificou-se associação entre reação e não atendimento da promessa. Isto demonstra que tais termos fazem parte do Contrato Psicológico, mesmo tendo sido pouco percebidos como prometidos pelas organizações. Ou seja, assim como plano de carreira, os respondentes demonstram desejo pelo cumprimento destas promessas, indicando uma necessidade de revisão da relação entre indivíduos e organizações, inclusive no que compete ao diálogo.

Diante do exposto, pode-se concluir que o tipo psicológico exerce influência sobre o entendimento de como os Contratos Psicológicos se manifestam na relação com a organização, mas não exerce influência na captura dos mesmos, nem sobre o comportamento dos indivíduos diante do não cumprimento do contrato. Isto sugere a adoção de novos direcionamentos das pesquisas relacionadas, principalmente, ao entendimento de quais fatores levam indivíduos a reagirem (externa ou internamente) diante de uma ruptura do Contrato Psicológico e por quê. 


\section{Recomendações aos indivíduos e organizações}

Diante dos resultados desta pesquisa, recomenda-se que indivíduos e organizações ampliem o diálogo sobre os entendimentos recíprocos dos papéis e promessas assumidos na relação de trabalho. Para tanto, faz-se necessária a criação de práticas organizacionais que estimulem de forma estruturada este diálogo e entendimento sobre aquilo que é concreto e viável de ser cumprido por ambos. Sugere-se, também, que sejam elencados os representantes ou responsáveis pelo estabelecimento deste diálogo, de modo que as organizações sejam capazes de emitir sinais mais concretos e, principalmente, uníssonos, de modo que o entendimento sobre aquilo que é prometido para o indivíduo seja estendido para a coletividade de trabalhadores da organização, respeitando-se as particularidades individuais.

Para as organizações, recomenda-se atenção para os indicadores dos Contratos Psicológicos que apresentaram baixa percepção de promessa e, ainda sim, causaram reações emocionais e/ou afetivas nos indivíduos. O cuidado com tais indicadores permitirá maior alinhamento entre indivíduos e organizações, evitando que a violação ocorra, já que esta sinaliza um dano na relação entre empregador e empregado. Relações mais equilibradas podem produzir efeitos mais positivos aos índices de rotatividade voluntária nas organizações.

Para tanto, sugere-se a estruturação de um plano de carreira organizacional, que indique os possíveis caminhos a serem perseguidos nas organizações pelos indivíduos, diante das necessidades e objetivos de ambos, de modo que eles consigam prosseguir na gestão de suas carreiras. Ao oferecer um plano estruturado, com regras de ascensão claras e objetivas, o atendimento do indicador oportunidade de promoção ocorrerá, provavelmente, de forma natural.

Aos indivíduos, recomenda-se tomar as rédeas da gestão de suas carreiras, evitando posturas passivas. $\mathrm{O}$ estímulo às discussões sobre carreiras e oportunidades de promoção nas organizações pode partir de seus funcionários. 


\section{Contribuições da Pesquisa}

O presente trabalho almeja colaborar, do ponto de vista acadêmico e prático, para o desenvolvimento das ciências humanas, indivíduos, organizações e gestores de pessoas.

Às ciências humanas, espera-se contribuir para o avanço das pesquisas em Contratos Psicológicos no âmbito nacional e internacional. Atualmente, as pesquisas internacionais, principalmente desenvolvidas nos Estados Unidos da América (EUA), abrangem focos restritos. No Brasil, ainda são muito incipientes. Acredita-se, portanto, que suprir uma das muitas lacunas indicadas por autores renomados contribua para a expansão e aprofundamento das teorias sobre Contratos Psicológicos, impactando outras áreas importantes do conhecimento, como gestão de pessoas e comportamento organizacional.

Às organizações e gestores de pessoas, espera-se que este estudo contribua para um processo de reflexão sobre as tendências no campo das relações de trabalho, que vivenciam mudanças profundas promovidas pela nova configuração econômica e social, de modo a saber conduzi-las nas diversas esferas da vida organizacional. Espera-se que este trabalho permita o repensar dos modelos e práticas organizacionais, incluindo a forma de conduzir o processo de gestão de pessoas, de modo que indivíduos e organizações consigam estabelecer melhor comunicação e, com isso, encaixar as necessidades de cada uma das partes de uma forma mais madura e produtiva.

Aos indivíduos, espera-se que este estudo facilite o entendimento de cada um, naquilo que tange sua compreensão, sobre sua relação com a organização, permitindo interações mais saudáveis e menos dolorosas do seu ponto de vista. Espera-se, também, provocar uma profunda reflexão sobre os motivos ou razões que podem levá-los a determinados comportamentos e atitudes na vida organizacional. 


\section{Referencial Bibliográfico}

ARGYRIS, C. Understanding Organizational Behavior. Homewood, Il: Dorsey Press, 1960.

ARNOLD, J. The psychological contract: a concept in need of closer scrutiny? European Journal of Work and Organizational Psychology. V. 5, n. 4, pp. 511-20, 1996.

ARNOLD, J. The psychological contract: a concept in need of closer scrutiny? European Journal of Work and Organizational Psychology. V. 5, n. 4, pp. 511-20, 1996.

ARTHUR, M. B. et al. Intelligent enterprise, intelligent careers. Academy of Management Executive, n. 4, v.9, pp. 7-20, Nov. 1995.

ARTHUR, M. B. e ROUSSEAU, D. M. Introduction: the boundaryless career as a new employment principle. In:___ (ed.) The boundaryless career: a new employment principle for a new organizational era. New York: Oxford University, 1996.

BUSINESS WEEK. Preterm / Orientation - Preparing for B-School. Disponível em: http://www.businessweek.com/bschools/mbajournal/00keeton $/ 3 . h t m ? c h a n=s e a r c h . \quad$ Acesso em: 26/06/2008.

CASADO, Tânia. Tipos Psicológicos: Uma Proposta de Instrumento para Diagnóstico do Potencial Humano nas Organizações. 1998. Tese (Doutorado em Administração de Empresas) - Faculdade de Economia, Contabilidade e Administração da Universidade de São Paulo, São Paulo, 1998.

Tipos Psicológicos e Estilos de Comportamento Motivacional - o Diálogo entre Jung e Fromm. 1993. Dissertação. (Mestrado em Administração de Empresas) Faculdade de Economia, Contabilidade e Administração da Universidade de São Paulo, São Paulo, 1993.

CONWAY, N. e BRINER, R.B. A daily study of affective responses to psychological breach and exceeded promises. Journal of Organizational Behavior. V. 23, n. 3, pp. 287-302, Maio, 2002b.

CONWAY, N. e BRINER, R.B. Full-time versus Part-Time Employees: Understanding the Links between Work Status, the Psychological Contract, and Attitudes. Journal of Vocational Behaviour.. v. 61, pp. 279 - 301, 2002a.

CONWAY, N. e BRINER, R.B. Understanding Psychological Contracts at Work: a critical evaluation of theory and research. NewYork: Oxford University Press, 2005.

COSTA, W. C. Sindicalização e greves: história recente do movimento sindical brasileiro. Disponível em: http://www.anpuh.uepg.br/historia-hoje/vol2n6/walber.htm. Acesso em: 20/12/2008.

COYLE-SHAPIRO, J. e KESSLER, I. Consequences of the psychological contract for the employment relationship: a large scale survey. Journal of Management Studies. V.37, n.7, pp. 903 a 930, Novembro, 2000.

DELCAMPO, Robert. Psychological contract violation: an individual difference perspective. International Journal of Management., v. 24, n.1, pp.43-52, March, 2007.

FIA. Conheça a FIA. Disponível em: www.fia.com.br. Acesso em: 22/01/2009 
FOA, U. G. e FOA, E. B. Societal structures of the mind. Springfield, IL: Charles C Thomas, 1974.

FRIEDMAN, T. O mundo é plano: uma breve história do século XXI. Rio de Janeiro: Objetiva, 2005.

GUEST, D. E. Is the psychological contract worth taking serious? Journal of Organizational Behavior. V.19, pp. 649-664, 1998 a.

GUEST, D. E. On meaning, metaphor and the psychological contract: a response to Rousseau. Journal of Organizational Behavior. V.19, pp. 673-77, 1998 b.

GUEST, D. E. The psychology of the employment relationship: an analysis based on the psychological contract. Applied Psychology: An international review. V. 53, n. 4, pp. 541 $55,2004$.

GUZZO, R. A. e NOONAN, K. A. Human resource practices as communications and the psychological contract. Human Resource Management. v. 33, n. 3, pp. 447 - 62, fall, 1994.

GUZZO, R. A., NOONAN, K.A. e ELRON, E. Expatriate managers and the psychological contract. Journal of Applied Psychology. V. 79, pp. 617-26, 1994.

HAIR, J. F. Jr., ANDERSON, R. E., TATHAM, R. L e BLACK, W. C. Análise multivariada de dados. Porto Alegre: Bookman, 2005. $5^{\text {a }}$ edição.

HALL, C. S., LINDZEY, G. e CAMPBELL, J. B. Teorias da personalidade. Porto Alegre: Artmed Editora, 2000. $4^{\mathrm{a}}$ edição.

HANDY, C. B. The empty raincoat. London, UK: Random House, 1994.

HARRINGTON, B e HALL, D. T. Carrer management \& work-life: using self-assessment to navigate contemporary careers. Los Angeles: SAGE Publications, 2007.

HERRIOT, P. "New dealing", paper presented at The City University, London Conference: "The new deal in employment", December, 1995.

HERRIOT, P. e PEMBERTON, C. Facilitating new deals. Human Resource Management Journal. V. 7, pp. 45-56, 1997.

HERRIOT, P., MANNING, W. E. G. e KIDD, J, M. The content of psychological contract. British Journal of Management. V. 8, pp. 151-62, 1997.

HUI, C., LEE, C. e ROUSSEAU, D. M. Psychological contract and organizational citizenship behavoir in china: investigating generalizability and instrumentality. Journal of Applied Psychology. V. 89, n. 2, pp. 311-21, 2004.

JUNG, C. G. Tipos psicológicos. Petrópolis: Editora Vozes, 1991.

KERSEY, D. e BATES, M. Please understand me: Character and temperament types. 16a edição. Del Mar: Prometheus Nemesis, 1978.

KICKUL, J. R., LESTER, S.W e FINK, J. Promise braking during radical organizational change: do justice interventions make difference? Journal of Organizational Behavior. V. 23, pp. 469-88, 2002.

KIDDER, D. L. e BUCHHOLTZ, A K. Can excess bring success? CEO compensation and the psychological contracts. Human Resources Management Review, v. 12, pp. 599 - 617, 2002.

KOTTER, J. P. The psychological contract: managing the joining up process. California Management Review. V. 15, pp. 91-9, 1973. 
LAHTI, R. K. e BEYERLEIN, M. M. Knowledge transfer and management consulting: a look at the firm. Business Horizons, pp. 65 - 74, jan./fev. 2000.

LEE, T. W. e MAURER, S. D. The retention of knowledge workers with the unfolding model of voluntary turnover. Human Resources Management Review, v. 7, n. 3, pp. 247 - 275, 1997.

LESTER, S.W., TURNLEY, W.H., BLOODGOOD, J.M e BOLINO, M.C. Not seeing eye to eye: differences in supervisor and subordinate perceptions of and attributions for psychological contract breach. Journal of Organizational Behavior. V. 23, pp. 30-56, 2002.

LEVINSON, H. et al. Men, management and mental health. Cambridge, MA: Harvard University Press, 1963.

MACNEIL, I. R. Relational Contract: what we do and do not know. Wisconsin Law Sociology Review. V. 28, pp. 55-69, 1985.

MARTINS, G. A. Sobre confiabilidade e validade. RBGN. V. 8, n. 20. pp. 1-12, jan/abr 2006.

MECKLER, M., DRAKE, B.H e LEVINSON, H. Putting psychology back into psychological contracts. Journal of Management Inquiry. V.12, pp. 217-28, setembro 2003.

MENEGON, Leticia F. Contratos Psicológicos como fatores influenciadores dos índices de rotatividade voluntária em empresas de consultoria. 2004. Dissertação (Mestrado em Administração de Empresas) - Faculdade de Economia, Contabilidade e Administração da Universidade de São Paulo, São Paulo, 2004.

MENEGON, L. F. e CASADO, T. . O Contrato Psicológico e a Gestão de Pessoas: o impacto da ruptura na retenção de talentos.. In: Iberoamerican Academy of Management, 2005, Lisboa.

O contrato psicológico como ferramenta de gestão de pessoas. RAUSP - Revista de Administração. V. 41, n. 2, pp. 125 - 135, abr/mai/jun, 2006.

MENNINGER, K. Theory of psychoanalytic Technique. Segunda Edição. Nova York: Basic Books, 1958.

MILLWARD, L. J. e HOPKINS, L. J. Psychological contracts, organizational and job commitment. Journal of Applied Social Psychology. V. 28, n. 16, p. 1530-56, 1998.

MORRINSON, E. W. e ROBINSON, S. L. When employees feel betrayed: a model of how psychological contract violations develops. Academy of Management Review. V. 22, n. 1, pp. 226-56, 1997.

MORRISON, D. E. Psychological Contracts and Changes. Human Resource Management, v. 33, n. 3, pp. $353-372,1994$.

MYERS, I. B. e MYERS, P. B. Ser humano e ser diferente - valorizando as pessoas por seus dons especiais. São Paulo: Editora Gente, 1997.

MYERS, I. B. Gifts differing. Palo Alto: Consulting Pychologists Press, 1980.

O'REILLY, B. The new deal: what companies and employees owe one another. Fortune. New York, n. 12, v. 129, pp. 44-50, 13/06/1994.

PASTORE, J. Artigos - relações de trabalho. Disponível em: http://www.josepastore.com.br/artigos/rt/index.htm. Acesso em: 20/12/2008. 
PEARCE, J. L. Toward an organizational behavior of contract laborers: their psychological involvement and effects on employee co-workers. Academy of Management Journal, v. 36, n. 5, pp. 1082-1096, 1993.

PEYRAT-GUILLARD, D. Union discourse and perceived violation contract: a social contract-based approach. Industrial Relations. V. 63, n. 3, 2008.

RAJA, U., JOHNS, G. e NTALIANIS, F. The impact of personality on psychological contracts. Academy of Management Journal., v. 47, n. 3, pp. 350-367, 2004.

REIS, A. O. A.; MAGALHAES, L. M. A. e GONCALVES, W. L. Teorias da Personalidade em Freud, Reich e Jung. São Paulo: Editora Pedagógica e Universitária Ltda, 1984.

REVISTA EXAME. Na sala de aula com os CEOs. Disponível em: http://portalexame.abril.com.br/gestaoepessoas/m0040235.html. Acesso em: 26/06/08.

ROBINSON, S.L. e MORRINSON, E.W. Psychological contracts and OCB: the effect of unfulfilled obligations on civic virtue behavior. Journal of Organizational Behavior. V. 16, pp. 289-98, 1995.

ROBINSON, S.L. e ROUSSEAU, D. M. Violating the psychological contract: not the exception but the norm. Journal of Organizational Behavior. V. 15, pp. 245-59, 1994.

ROBINSON, S.L. Trust and breach of the psychological contract. Administrative Science Quaterly. v. 41, pp. 574-99, 1996.

ROBINSON, S.L., KRAATZ, M.S. e ROUSSSEAU, D.M. Changing obligations and the psychological contract: a longitudinal study. Academy of Management Journal. V. 37, pp. 137-52, 1994.

ROBINSON, S.L.. Violations of psychological contracts: impact on employee attitudes. In: L.E. Tetrick and J. Barlings (eds). Changind employment relations: Behavioral and social perspectives. Washington DC: American Psychological Association, pp. 91-108, 1995.

RODRIGUES, L. M. Destino do sindicalismo. São Paulo:Editora USP, 2002.

ROEHLING, M.V. The origins and the early development of the psychological contract construct. Artigo apresentado no Annual Meeting of the Academy of Management, Cincinnati, 1996.

ROUSSEAU, D. M. e PARKS, J. M. The contracts of individuals and organizations. Research in Organizational Behavior. V. 15, pp. 1-43, 1993.

ROUSSEAU, D. M. e TIRORIWALA, S.A. Assessing psychological contracts: issues, alternatives and measures. Journal of Organizational Behavior. V. 19, çp. 679-95, 1998.

ROUSSEAU, D. M. New hire perceptions of their own and their employer's obligations: a study of psychological contracts. Journal of Organizational Behavior. V.11, çp. 389-400, 1990.

ROUSSEAU, D. M. Psychological and implied contracts in organizations. Employee Responsibilities and Rights Journal. V. 2, çp. 121-139, 1989.

ROUSSEAU, D. M. Psychological contracts: understanding written and unwritten agreements. Thousands Oaks, CA: Sage, 1995.

ROUSSEAU, D. M. The 'problem' of psychological contract considered. Journal of Organizational Behavior. V.19, pp. 665-71, 1998 
RUBERY, J. et all. Changing organizational forms ant the employment relationship. Journal of Management Studies. V. 39, n. 5, pp. 645 - 672, Julho, 2002.

SAMPIERI, R. H., COLLADO, C. H. e LUCIO, P. B. Metodologia de Pesquisa. Tradução Fátima Conceição Murad, Melissa Kassner, Sheila Clara Dystyler Ladeira. Revisão técnica e adaptação: Ana Gracinda Queluz Garcia, Paulo Heraldo Costa do Valle. Terceira edição. São Pauklo: McGraw-Hill, 2006.

SCALABRIN, Ana Carla. Carreiras sem fronteiras e trajetórias descontínuas: um estudo descritivo sobre as decisões de pot-out. 2008. Dissertação. (Mestrado em Administração de Empresas) - Faculdade de Economia, Contabilidade e Administração da Universidade de São Paulo, São Paulo, 2008.

SCHEIN, E.H. Organizational Psychology. Englewoods Cliffs, NJ: Prentice Hall, 1965, 1980.

SELLTIZ, C. et. al. Métodos de pesquisa nas relações sociais. São Paulo: Editora da Universidade de São Paulo, 1974.

SHORE, L.M. e TETRICK, L. E. The psychological contract as an explanatory framework in the employment relationship. In: C.L. Cooper e D. M. Rousseau. Trends in organizational Behavior. New York: Wiley, pp. 91-103.

SPINDLER, S. G. Psychological contracts in workplace - a lawer's view. Human Resource Management. V. 33, pp. 325-34, 1994.

STEWART, T. A. Intellectual Capital - The new wealth of organizations. Segunda Edição. New York, NY: Currency Doubleday, 1999.

TURNLEY, W. H. e FELDMAN, D. C. A discrepancy model of psychological contract violations. Human Resources Management Review, v. 9, n. 3, pp. 367 - 386, 1999.

TURNLEY, W. H. e FELDMAN, D. C. Re-examining the effects of psychological contract violations: unmet expectations and job dissatisfaction as mediators. Journal of Organizational Behavior. v. 21, pp. 25-42, 2000.

VOCE SA. Juntos chegaremos lá? Disponivel em: http://vocesa.abril.com.br/edicoes/0081/fechado/evolucao/mt_62863.shtml. Acesso em: 26/06/2008.

VROOM, V. H. Work and motivation. New York: Wiley, 1964.

WHEELWRIGHT, J. B., WHEELWRIGHT, J. H. e BUEHLER, H. A. Jungian Type Survey: the gray wheelwright test. Sao Francisco: Society of Jungian Analysts of Nothern California, 1964.

ZACHARIAS, J. J. M. Tipos: a diversidade humana. São Paulo: Vetor editora psicopedagógica, 2006.

HALL, D. T. Careers in and out of organizations. Thousand Oaks, CA: Sage Publications, 2002.

HALL, D. T. e MOSS, J. E. The new protean career contract: helping organizations and employees adapt. Organizational Dynamics, v.26, n. 3, pp. 22-27. 


\section{Apêndice 1}

O questionário apresentado é apenas um extrato do original. Para obtenção do questionário na íntegra, favor entrar em contato com Letícia F. Menegon pelo email:

letícia.menegon@gmail.com, ou com a Profa. Tânia Casado pelo email: tcasado@usp.br

Prezado (a) respondente:

$\mathrm{O}$ instrumento de pesquisa que segue foi desenhado com o objetivo de entender o relacionamento entre organizações e indivíduos. Ele está dividido em 4 seções, cada uma com suas particularidades. Siga as instruções contidas no desenrolar do questionário e, para respondê-lo, considere seu emprego atual e sua relação com a organização desde os primeiros contatos até a atualidade. O tempo médio de resposta do mesmo é de 15 minutos.

É importante que responda o questionário até o fim, e se possível, em uma única vez! Por favor, não permita que outra pessoa responda o questionário por você!

Muito obrigada por sua participação! 


\section{SEÇÃO I: DADOS GERAIS}

Por favor, responda todas as questões que seguem.

1) Idade:

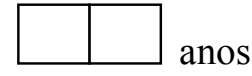

2) Gênero: (1)___ Feminino (2) __ Masculino

3) Educação formal:

(1)__ Superior Completo

(2)__ Pós-graduação Incompleta

(3)__ Pós-graduação Completa

(4)__ Mestrado Incompleto

(5)__ Mestrado Completo

(6)__ Doutorado Incompleto

(7)__ Doutorado Completo

4) Tempo de experiência profissional na empresa atual: \begin{tabular}{|l|l|}
\hline & anos
\end{tabular}

6) Segmento do atual emprego

\begin{tabular}{|l|l|l|l|}
\hline & 1 - Agroindústria & $14-$ Consultoria \\
\hline 2 - Entretenimento & & 15 - Informática \\
\hline 3 - Indústria de bens de capital & $\begin{array}{l}16 \text { - Indústria automobilistica e de } \\
\text { autopeças }\end{array}$ \\
\hline $\begin{array}{l}4-\text { Indústrias química e } \\
\text { famaceutica }\end{array}$ & 17 -Indústria de papel e celulose \\
\hline $5-$ Serviços de saúde & & $18-$ Serviços \\
\hline 6 - Telecomunicações & & $19-$ Serviços públicos \\
\hline $7-$ Construção civil & & 20 - Outros \\
\hline $8-$ Industria alimenticia & & \\
\hline $9-$ Industria de bens de consumo & & \\
\hline $10-$ Industria têxtil & & \\
\hline $11-$ Produtos e serviços de TI & & \\
\hline $12-$ Serviços Financeiros & & \\
\hline $13-$ Varejo, bens e serviços & & \\
\hline
\end{tabular}


7) Área de atuação

\begin{tabular}{|c|c|}
\hline 1 - Administração de projetos & 14 - Marketing \\
\hline 2 - Contabilidade & 15 - Produção \\
\hline 3 - Jurídica & 16 - Sistemas de Informação \\
\hline 4 -Pesquisa e Desenvolvimento & 17-Comércio Varejista \\
\hline 5 - Recursos Humanos & 18 -Informática/TI \\
\hline 6 - Telecomunicações & 19 - Qualidade Total \\
\hline 7 - Administração Geral & 20 - Suprimentos \\
\hline 8 - Educação & $21-$ Outros \\
\hline 9 -Logística & \\
\hline 10 - Planejamento Estratégico & \\
\hline 11 - Saúde & \\
\hline 12 -Comercial & \\
\hline 13 - Finanças & \\
\hline
\end{tabular}




\section{SEÇÃO II}

\section{Coluna Indicadores}

1) Oportunidade de promoção

2) Remuneração equivalente ao mercado e na organização
Coluna A

Coluna B

Coluna C

$\mathrm{Na}$ sua opinião, indique em que extensão a organização prometeu prover os itens pertencentes à Coluna Indicadores, usando a seguinte escala:

1 - Não prometeu 2- Insinuou levemente 3 Deixou forte impressão de promessa, mas nenhuma promessa efetiva

4 - Prometeu escrita ou verbalmente

1 3

4

$\begin{array}{llll}1 & 2 & 3 & 4\end{array}$

W) Analisando globalmente todos os itens não atendidos ou atendidos parcialmente de TODA a coluna B (ou seja, desde a primeira até a última pagina da seção II), você se sentiu lesado em algum momento pela organização? Responda circulando apenas uma das respostas a seguir: 


\section{SEÇÃO III}

Analisando todo o contexto de respostas da Seção II e seu relacionamento com a organização, responda as sentenças a seguir em uma escala de 10 pontos, em que $\mathbf{0}$ (zero) equivale a absoluta discordância e $\mathbf{1 0}$ equivale a absoluta concordância..

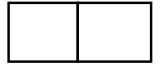

1. Senti vontade de me vingar da organização e/ou das pessoas que a representam.

2. Senti uma queda no meu nível de energia.

3. Senti um descontentamento que dura até hoje. 


\section{SEÇÃO IV}

Pensando no seu relacionamento com a empresa onde trabalha, assinale na escala apresentada, seu grau de concordância ou discordância sobre vários aspectos envolvidos nesse relacionamento. Observe que na escala apresentada, 0 equivale a absoluta discordância e 10 equivale a absoluta concordância. Muito obrigada por sua participação!

1) Qualquer treinamento que eu participe deve estar exclusivamente associado ao trabalho que realizo na organização.

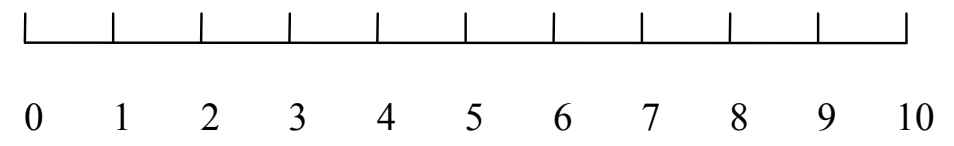

2) A minha relação com a organização se baseia em termos claros, objetivos e explícitos, não gerando problemas de entendimento entre as partes.

$\begin{array}{llllllllllll} & & & & & & & & & & \mid & \\ \end{array}$

3) Minha estada nesta organização é por tempo limitado.

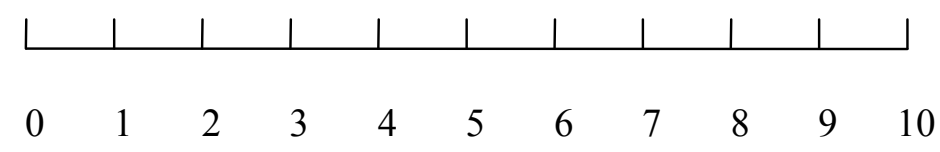




\section{Apêndice 2}

Título da Mensagem: Pesquisa sobre contratos psicológicos

Meu Prezado Aluno/Ex-Aluno,

Espero que você esteja bem.

Durante nossas aulas tivemos a oportunidade de conversar sobre aspectos importantes sobre carreira e uso pleno do potencial humano.

O conteúdo de nossas aulas é fruto de estudos acadêmicos e de contatos com profissionais práticos das organizações. A integração entre os conceitos da academia com a experiência dos executivos tem trazido resultados para todos os envolvidos.

Por essa razão, sinto-me à vontade para solicitar uma gentileza: que você preencha um questionário que será enviado para você, por email.

O questionário é parte da coleta de dados da tese de minha orientanda de Doutorado Letícia Fantinato Menegon, que também é professora em programas de educação continuada da FIA. O tema do trabalho é: "Contratos Psicológicos".

Peço, por favor, que contribua com a nossa pesquisa.

Reserve cerca de 15 minutos para responder ao questionário. Você receberá um email da própria Letícia, com as instruções necessárias.

Como agradecimento pela participação, eu e Letícia faremos uma palestra sobre o assunto e sobre os resultados do estudo, a todos os respondentes.

Muito obrigada e um forte abraço,

Tania 
Apêndice 3

Título da mensagem: Pesquisa sobre contratos psicológicos

Prezados alunos e ex-alunos da FIA,

Meu nome é Letícia Fantinato Menegon, sou aluna do curso de Doutorado em Administração de Recursos Humanos na FEA-USP, orientanda da Profa. Dra. Tania Casado. Tenho estudado o assunto Carreiras e em especial, Contratos Psicológicos, que é o tema de minha Tese de Doutorado.

Você já deve ter recebido uma mensagem da Profa. Tania Casado, solicitando sua colaboração. Agradeço muito àqueles que puderem responder à minha pesquisa! Entre os dias 25 de agosto a 10 de setembro, coletarei os dados para minha tese por meio de um questionário online. Para isso, por favor, reserve 15 minutos. Clique no link abaixo e acompanhe as instruções para responder ao questionário.

\#LinkPesquisa\#

Em agradecimento aos respondentes, eu e a Profa. Tania Casado faremos uma palestra sobre o tema e os resultados da pesquisa, após a apresentação da Tese. Isso deverá acontecer $\begin{array}{lllll}\text { entre } & \text { os } & \text { meses } & \text { fevereiro/março }\end{array}$ Agradeço desde já sua participação! Qualquer duvida estou à disposição pelo email: letícia.menegon@gmail.com.

Atenção! Se você não conseguir abrir o link pelo computador de sua empresa, encaminhe este email para seu email pessoal.

Obrigada mais uma vez.

Um grande abraço!

Letícia F. Menegon 
NOTA: Alguns programas de email podem dividir o endereço acima em duas linhas. Se uma página de erro for exibida, remova a quebra de linha, copie e cole o endereço completo no navegador internet.

O link do questionário é único, pessoal e intransferível. Em caso de dúvidas entre em contato conosco. 
Apêndice 4

Titulo Mensagem: Aluno e Ex-aluno, Novamente meu pedido.

Olá Prezado Aluno e Ex-aluno,

Eu e minha orientanda Letícia Menegon enviamos duas mensagens a você e a outros ex-alunos, solicitando sua colaboração no preenchimento de um questionário. Rapidamente, muitas pessoas responderam. O número ideal, exigido pelos critérios e metodologia adotados, está muito perto de ser atingido. Por essa razão, enviamos esta mensagem para aqueles cuja resposta ainda não recebemos, mais uma vez solicitando sua colaboração. Temos até segundafeira (dia 7 de setembro) para coletar os dados. Sabendo que seu tempo é precioso, agradecemos sua colaboração antecipadamente. Espero que nos encontremos na palestra de apresentação dos resultados do estudo de doutorado de Letícia.

Um abraço,

Tania. 


\section{Apêndice 5}

\section{Tabela 1: Estatísticas para a Prova de Mann-Whitney}

\begin{tabular}{|c|c|c|c|c|c|c|c|}
\hline & conglomerado & $\mathrm{N}$ & $\begin{array}{l}\text { Média de } \\
\text { pontuação }\end{array}$ & $\begin{array}{l}\text { Média de } \\
\text { Postos }\end{array}$ & $\begin{array}{c}\text { Soma de } \\
\text { Postos }\end{array}$ & $\mathrm{z}$ & $\mathrm{p}$ \\
\hline \multirow[t]{2}{*}{$\begin{array}{l}\text { Senti vontade de me vingar da organização e/ou das pessoas que a } \\
\text { representam. }\end{array}$} & conglomeradoviolação & 71 & 3,4 & 116,74 & 8288,5 & $-7,428$ & 0 \\
\hline & conglomeradonão violação & 103 & 0,4 & 67,34 & 6936,5 & & \\
\hline \multirow[t]{3}{*}{ Senti uma queda no meu nível de energia } & conglomeradoviolação & 71 & 8,5 & 136,16 & 9667,5 & $-10,651$ & 0 \\
\hline & conglomeradonão violação & 103 & 2,8 & 53,96 & 5557,5 & & \\
\hline & conglomeradonão violação & 103 & 1,4 & 56,43 & 5812,5 & & \\
\hline \multirow[t]{2}{*}{$\begin{array}{l}\text { Tive a oportunidade de retaliar uma pessoa (ou grupo de pessoas) e } \\
\text { assim o fiz. }\end{array}$} & conglomeradoviolação & 71 & 1,4 & 99,38 & 7056 & $-3,542$ & 0 \\
\hline & conglomeradonão violação & 103 & 0,3 & 79,31 & 8169 & & \\
\hline \multicolumn{8}{|l|}{ Senti desinteresse pelas coisas que me cercavam.) } \\
\hline & conglomeradoviolação & 71 & 7,0 & 134,23 & 9530,5 & $-10,319$ & 0 \\
\hline & conglomeradonão violação & 103 & 1,5 & 55,29 & 5694,5 & & \\
\hline \multirow[t]{2}{*}{ Passei a não acatar todas as ordens como forma de protesto.) } & conglomeradoviolação & 71 & 3,1 & 116,44 & 8267 & $-7,252$ & 0 \\
\hline & conglomeradonão violação & 103 & 0,3 & 67,55 & 6958 & & \\
\hline \multirow[t]{2}{*}{ Nasceu em mim um sentimento de aversão à organização.) } & conglomeradoviolação & 71 & 4,9 & 126,76 & 9000 & $-9,142$ & 0 \\
\hline & conglomeradonão violação & 103 & 0,5 & 60,44 & 6225 & & \\
\hline \multirow[t]{2}{*}{ Passei a sentir ansiedade na minha relação com a organização.) } & conglomeradoviolação & 71 & 6,6 & 128,94 & 9155 & $-9,159$ & 0 \\
\hline & conglomeradonão violação & 103 & 1,4 & 58,93 & 6070 & & \\
\hline \multirow[t]{2}{*}{ Senti raiva em relação à organização.) } & conglomeradoviolação & 71 & 4,6 & 123,35 & 8758 & $-8,298$ & 0 \\
\hline & conglomeradonão violação & 103 & 0,6 & 62,79 & 6467 & & \\
\hline \multirow{2}{*}{ Senti que a organização foi desleal comigo.) } & conglomeradoviolação & 71 & 5,5 & 124,82 & 8862 & $-8,552$ & 0 \\
\hline & conglomeradonão violação & 103 & 0,8 & 61,78 & 6363 & & \\
\hline \multirow[t]{2}{*}{ Fui apunhalado pela costas.) } & conglomeradoviolação & 71 & 3,6 & 113,3 & 8044,5 & $-6,806$ & 0 \\
\hline & conglomeradonão violação & 103 & 0,3 & 69,71 & 7180,5 & & \\
\hline
\end{tabular}

Fonte: autoria própria, com base em pesquisa para esta tese. 


\section{Anexos}

Table 5.2 The effects of psychological contract breach on job satisfaction, organizational commitment, and the intention to qut

\begin{tabular}{|c|c|c|c|c|c|}
\hline \multirow[b]{2}{*}{ Authors } & \multirow[b]{2}{*}{ vour } & \multirow[b]{2}{*}{$\begin{array}{l}\text { Sampe } \\
\text { size }\end{array}$} & \multicolumn{3}{|c|}{ Correlation coetticient tetween treach and cutcome } \\
\hline & & & Job satisfaction & $\begin{array}{l}\text { Orgenicultiontul } \\
\text { commitment }\end{array}$ & Intenton to quit \\
\hline Cross-sectional studies & & & & & \\
\hline $\begin{array}{l}\text { Teklean, Takeuchi, } \\
\text { unc Taylor }\end{array}$ & 2005 & 200 & -0.37 & & 0.14 \\
\hline Sutton and Gritin & 2004 & 235 & -0.57 & & 0.32 \\
\hline $\begin{array}{l}\text { Faja, Johns, } \\
\text { and Ntalianis }\end{array}$ & 2004 & 197 & -0.30 & -0.49 & 0.48 \\
\hline $\begin{array}{l}\text { Johnson and } \\
\text { O'Leary-Kely }\end{array}$ & 2003 & 103 & -0.59 & -0.52 & \\
\hline o and Aryee & 2003 & 152 & & & 0.48 \\
\hline Tekleab and Taylor & 2003 & 130 & -0.34 & & 0.23 \\
\hline Snnway' and Briner & 2002 & 1608 & -0.57 & 0.41 & 0.42 \\
\hline Cunway and Briner & 2002 & 366 & -0.57 & -0.39 & C.4i \\
\hline $\begin{array}{l}\text { K rkul, Lester, } \\
\text { and rinkl }\end{array}$ & 2002 & 246 & $\begin{array}{l}-0.35 \text { iextrinsic } \\
-0.53 \text { intrirsic }\end{array}$ & & $\begin{array}{l}\text { C. } 16 \text { extrirsic; } \\
0.38 \text { (ntr nsic) }\end{array}$ \\
\hline Lester et al. & 2002 & 134 & & -0.25 & \\
\hline Bunderson & 2001 & 283 & $\begin{array}{l}0.04 \text { (acministratwe) } \\
0.36 \text { iprotessinna? }\end{array}$ & $\begin{array}{l}0.17 \text { (admin strative) } \\
-0.50 \text { (professionali) }\end{array}$ & $\begin{array}{l}0.02 \text { (administative) } \\
0.34 \text { (profestiontal) }\end{array}$ \\
\hline $\begin{array}{l}\text { Flood, T.urner, } \\
\text { Rimimaorthy. } \\
\text { and Pearson }\end{array}$ & 2001 & 402 & & 0.42 & 0.47 \\
\hline Turrloy and leloman & 2000 & 894 & -0.56 & & 0.48 \\
\hline $\begin{array}{l}\text { Coyle-Shipire } \\
\text { and Kessler }\end{array}$ & 2000 & 6953 & $\begin{array}{l}-0.38 \text { (transact onal) } \\
-0.46 \text { (trairing) } \\
0.46 \text { (frelational) }\end{array}$ & $\begin{array}{l}\text {-0.30 itransactional; } \\
-0.27 \text { itra ningi) } \\
-0.23 \text { irelat onal) }\end{array}$ & \\
\hline Tumleys and Feldman & 1999 & 804 & & & 0.38 \\
\hline Cavanaug and Noc & 1599 & 136 & -0.72 & & 0.25 \\
\hline $\begin{array}{l}\text { Guzzo, Noonan, } \\
\text { and Elron }\end{array}$ & 1994 & 148 & & 0.27 & 0.15 \\
\hline Robirson $\equiv n d$ Roussedu & 1994 & 128 & -0.76 & & 0.42 \\
\hline Average correlation & & & 0.46 & -0.32 & 0.33 \\
\hline Longitudinal studies & & & & & \\
\hline Bunderson & 2001 & 167 & $\begin{array}{l}0.17 \text { (administrative) } \\
-0.28 \text { (onofossionalj) }\end{array}$ & $\begin{array}{l}0.10 \text { iadrrinistratwe) } \\
\text { 0.47 ipotessinna? }\end{array}$ & $\begin{array}{l}0.19 \text { iudm nistra we) } \\
0.29 \text { ipratessiora! }\end{array}$ \\
\hline
\end{tabular}

Motes for Tables 5.2 to 5.5 :

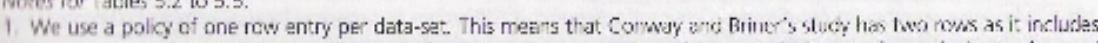

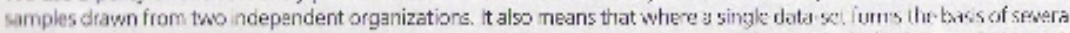
empirical papes, and where the same finding is reported acoss two or more urtices, we include l"we curration on ence. For example, fobinson (1996) and focinson and Mornson (1995) report correlations frem the same data-sat, so only one of the papers is included in Table 5.4 .

7. Terms in brackets following correlation coefficients indicate where a specific dimension of breach was measured ie.g 'transactonal' refers to a measure of transactional contract breachi. The awerage correlation indudes correlaticns between outcomes and dimensons of breach.

Fonte: Conway e Briner, 2005, p. 73. 
Table 5.3 The effects of psychological contract breach on employee turnover

\begin{tabular}{|c|c|c|c|}
\hline Authers & Year & Sample size & Emp oyees actual $y$ quitting ico relation $r$ \\
\hline Tekleab, Takeuchi, anc Toylor & 2005 & 191 & -0.02 \\
\hline Burdersar & 2001 & 283 & $\begin{array}{l}0.17 \text { (administratime) } \\
3.95 \text { (professionalj }\end{array}$ \\
\hline Rob nson & 1996 & 125 & 0.20 \\
\hline Average correlation & & & 0.11 \\
\hline
\end{tabular}

Table 5.4 The effects of psychological contract breach on organizational citizenship behaviour

\begin{tabular}{|c|c|c|c|c|}
\hline Authors & Year & Samp e size & ocs neasure & Cor'eation : \\
\hline \multicolumn{5}{|l|}{ Cross-sectional studies } \\
\hline Coyle-Srapirc and Kessler & 2000 & 6953 & General medsure, sef-report & $\begin{array}{l}-0.02 \text { (transactional; } \\
-0.22 \text { itra ning) } \\
-0.16 \text { irela sonal) }\end{array}$ \\
\hline 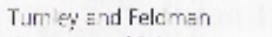 & 2000 & $80<$ & General measure, self-report. & -0.46 \\
\hline Corvidy and Briner & $2002 a$ & 1608 & Gerea measure, self-report & -0.14 \\
\hline Conway and Briner & $2002 b$ & 365 & Gereral measure, selt-report & -0.15 \\
\hline Kckul, Lester, and Finkl & 2002 & 245 & $\begin{array}{l}\text { OCBIs, sel-reocht } \\
\text { OCBOs, self-repor: }\end{array}$ & $\begin{array}{l}-0.01 \text { iextrinsic PCE; } \\
-0.07 \text { (int insic PCB; } \\
-0.05 \text { (extrins C PCE) } \\
-0.05 \text { int nsic PCB: }\end{array}$ \\
\hline Turnley ard Feldmar & 1999 & 304 & Loyalty subsca e, sef-report & -0.45 \\
\hline Lo and Ayee & 2003 & 52 & $\begin{array}{l}\text { Cvic vitue (a d mension cf OcB). } \\
\text { self-repert }\end{array}$ & -0.31 \\
\hline Turnley et al. & 2003 & 134 & $\begin{array}{l}\text { OCB 5, superisor-rated } \\
\text { ocBCs, supervisor-rated }\end{array}$ & $\begin{array}{l}-0.11 \text { (pay) } \\
-0.30 \text { (reationship) } \\
-0.3^{*} \text { (pay) } \\
-0.45 \text { irelatonship) }\end{array}$ \\
\hline Kic<ul, Lester, and Fin $<1$ & 2002 & 322 & $\begin{array}{l}\text { Anti-citizenship oehawiour, } \\
\text { supenisor-reted }\end{array}$ & -0.33 ireversed) \\
\hline$T=k$ eab and Tayla & 2003 & 130 & OCB, s.jperisor-rated & -0.16 \\
\hline Johnsch and O'Lea $y$-Kelly & 2003 & 103 & $\begin{array}{l}\text { Helping behavours, rated } \\
\text { ty colleagues }\end{array}$ & -0.07 \\
\hline Average effect size & & & & -0.20 \\
\hline \multicolumn{5}{|l|}{ Longitudinal studies } \\
\hline Robinson & 1996 & 125 & Civic virtue, self-report & -0.25 \\
\hline
\end{tabular}

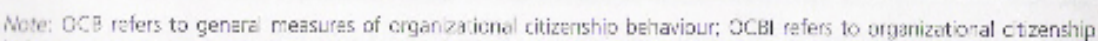

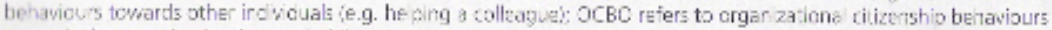
towards the organization ia.g. ...helding the crqonizajicn's reputaticn o-tsids worki.

\section{Fonte: Conway e Briner, 2005, p.74}


Table 5.5 The effects of breach on porformance

\begin{tabular}{|c|c|c|c|c|}
\hline Authers & rear & Semple size & Pertormaice measur: & Comelatur: \\
\hline \multicolumn{5}{|l|}{ Cross-sectional studies } \\
\hline Tekleac and Tayler & 2003 & 130 & $\begin{array}{c}\text { Operal potarmance, } \\
\text { superisor faled }\end{array}$ & 0.11 \\
\hline Ju'nnsan and OLeary-Kelly & 2003 & 103 & $\begin{array}{l}\text { In-role per ormanes, } \\
\text { superwisn rated }\end{array}$ & -433 \\
\hline Tumeye- al. & 2003 & 134 & in-role, supseviser rated & $\begin{array}{l}-0.20 \text { ivayi } \\
-0.41 \text { 'relationship: }\end{array}$ \\
\hline Kiccul, Lester, and Finkl & 2002 & 246 & $\begin{array}{l}\text { Ir-rce petorimance, } \\
\text { self report }\end{array}$ & - coos sintringic breachj \\
\hline Lesteret al. & 2002 & 134 & $\begin{array}{l}\text { Cwerall jub pertomance. } \\
\text { self-ated }\end{array}$ & $\begin{array}{l}-0.08 \text { iextrinsic breach) } \\
0.07\end{array}$ \\
\hline & & & $\begin{array}{l}\text { Overal bl petomance, } \\
\text { supervisor-rated }\end{array}$ & -0.37 \\
\hline Average effect size & & & & -0.19 \\
\hline \multicolumn{5}{|l|}{ Longitudinal studies } \\
\hline Buncerson & 2001 & 12.3 & $\begin{array}{l}\text { Objactive ob pertormance } \\
\text { derived trom orgar zational } \\
\text { records }\end{array}$ & 0.13 (udministrative) \\
\hline isol: ison & $1 \div 96$ & 125 & $\begin{array}{l}\text { Overall joo oer iormance, } \\
\text { sel'-rcuurt }\end{array}$ & $\begin{array}{l}-0.21 \text { iprotess ondul! } \\
-0.18\end{array}$ \\
\hline Average effect size & & & & -0.09 \\
\hline
\end{tabular}

Fonte: Conway e Briner, 2005, p.75 